\title{
O LAZER NA TRAJETÓRIA DE VIDA DE MULHERES IDOSAS DA AMAZÔNIA BRASILEIRA OCORRENCIAS EM PORTO VELHO
}

RAMÓN NUÑEZ CARDENAS IVETE DE AQUINO FREIRE

[OROS.]

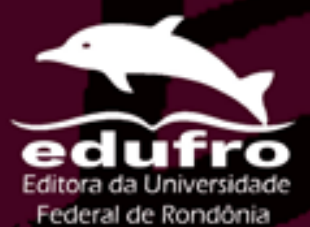




\section{O LAZER NA TRAJETÓRIA DE VIDA DE MULHERES IDOSAS DA AMAZÔNIA BRASILEIRA: OCORRÊNCIAS EM PORTO VELHO}

Ramón Núñez Cárdenas

Ivete de Aquino Freire

(Organizadores) 
Reitor Ari Miguel Teixeira Ott

Vice-Reitor José Juliano Cedaro

EDITORA DA UNIVERSIDADE FEDERAL DE RONDÔNIA

$\begin{array}{ll} & \text { CONSELHO EDITORIAL } \\ \text { Presidente } & \text { Lou-Ann Kleppa } \\ & \text { Ariana Boaventura Pereira } \\ \text { Carlos Alexandre Trubiliano } & \text { Eliane Gemaque Gomes Barros } \\ & \text { Gean Carla Silva Sganderla } \\ \text { Leandro Soares Moreira Dill } & \text { Márcio Secco } \\ & \text { Marli Lúcia Tonatto Zibetti } \\ & \text { Pedro Ivo Silveira Andretta } \\ & \text { Ricardo Gilson da Costa Silva } \\ & \text { Xênia de Castro Barbosa }\end{array}$

Editora Filiada
Edufro - Editora da Universidade Federal de Rondônia BR 364, Km 9,5
Campus Unir
76801-059 - Porto Velho - RO
Tel.: (69) 2182-2175
www.edufro.unir.br edufro@unir.br




\section{O LAZER NA TRAJETÓRIA DE VIDA DE MULHERES IDOSAS DA AMAZÔNIA BRASILEIRA: OCORRÊNCIAS EM PORTO VELHO}

Ramón Núñez Cárdenas

Ivete de Aquino Freire

(Organizadores)

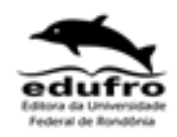

Porto Velho - RO 
(C) 2020 by Rámon Núñez Cárdenas e Ivete de Aquino Freire (organizadores) Esta obra é publicada sob a Licença Creative Commons Atribuição-Não Comercial 4.0 Internacional.

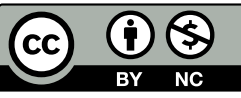

\author{
Capa: \\ Vitoria Gonçalves Morão \\ Revisão: \\ Dra. Jeane Mari Spera \\ Projeto gráfico: \\ Edufro - Editora da Universidade Federal de Rondônia \\ Diagramação: \\ Guilherme André de Campos \\ Impressão e acabamento: \\ Seike \& Monteiro Editora \\ Aprovado no Edital 02/2018/EDUFRO
}

Dados Internacionais de Catalogação na Publicação

Fundação Universidade Federal de Rondônia (UNIR)

Ficha Catalográfica elaborada pela Biblioteca Central da UNIR

F981 Fundação Universidade Federal de Rondônia.

O lazer na trajetória de vida de mulheres idosas da Amazônia brasileira: ocorrências em Porto Velho / organização Ramón Núñez Cárdenas, Ivete de Aquino Freire. - Porto Velho, RO: EDUFRO, 2020.

194 p.; il.

ISBN: 978-65-87539-18-8 (físico)

ISBN: 978-65-87539-10-2 (digital)

1. Esporte e lazer. 2. Saúde da Mulher. 3. Mulher - Amazônia. 4. História Oral. I. Cárdenas, Ramón Núñez. II. Freire, Ivete de Aquino. III. Fundação Universidade Federal de Rondônia.

CDU 613.7:379.8-055.2(811) 


\section{PREFÁCIO}

A pesquisa pela "História Oral" associada à "Trajetória de Vida" e estudo sobre o lazer de mulheres idosas da Amazônia Brasileira é de utilidade não só acadêmica como também pública. Isso porque pode contribuir para revitalizar a nossa história política pela valorização de memórias de protagonistas que, muitas vezes, permanecem à margem da história oficial das políticas públicas de esporte e lazer.

Por isso, destaco a grande importância de estudos como este, que explicitam, na íntegra, as falas de suas depoentes. Falas de práticas e experiências acumuladas ao longo da vida, desde a infância, que nos ajudam a compreender de modo mais amplo e globalizante significados da vida humana e suas relações com a sociedade organizada, as redes de sociabilidade, assim como o poder e contrapoder existentes. Falas que desvelam processos macro culturais que são constituídos no ambiente dentro do qual os atores sociais se movem de modos diferentes.

Este estudo, que tenho o prazer de apresentar, também nos alerta para a importância do protagonismo dos cidadãos e das cidadãs nas nossas ações políticas, especialmente, voltadas aos idosos e comunidades da Amazônia. É importante destacar que, segundo os autores do livro, somente uma das depoentes não nasceu na Amazônia, mas integrou a pesquisa uma vez que a sua família veio para Porto Velho a partir do incentivo do Governo Federal para povoar a Amazônia. Nesse caso, tratava-se do recrutamento de nordestinos para o trabalho nos seringais da região Amazônica, gerando integração desses sujeitos à vida sociocultural histórica da região. Cenário ainda pouco investigado no que tange aos estudos sobre lazer na trajetória de vida de idosas.

Assim, em primeiro lugar, parabenizo todos/as pesquisadores/as pela iniciativa de adentrarem ao território de investigações sobre idosos em nosso meio. Em segundo lugar, parabenizo também pelo conteúdo apresentado neste livro, que é muito adequado às nossas discussões sobre a qualificação das políticas públicas inclusivas de esporte e lazer. 
Conteúdo que se expressa por meio de um texto fluente, claro e de fácil entendimento, enriquecido por dados extraídos de "histórias orais" e pesquisas bibliográficas que, certamente, irão instigar o desenvolvimento de outros estudos sobre o tema investigado.

Por esses motivos, recomendo este livro para profissionais, educadores e estudantes de diversos setores que atuam ou que pretendem atuar na área de lazer para idosos.

Leila Mirtes Magalhães Pinto 


\section{Sumário}

9

APRESENTAÇÃO

13

1. ALGUNS ASPECTOS TEÓRICOS PARA ESTUDOS DESCRITIVOS DO LAZER

Ivete de Aquino Freire

Ramón Núñez Cárdenas

Andrea Nascimento Ewerton

45 2. A HISTÓRIA ORAL NA MODALIDADE TRAJETÓRIA DE VIDA COMO PROPOSTA DE PRODUÇÂO DO CONHECIMENTO EM PESQUISA SOBRE LAZER

Ivete de Aquino Freire

Ramón Núñez Cárdenas

Lilian Maria Moser

Iná de Aquino Freire

Idê Freire Seixas

Stefhany Soares Maia

61 3. MANIFESTAÇÕES DE LAZER NA HISTÓRIA DE VIDA DE IDOSAS DE PORTO VELHO: DA INFÂNCIA À MENINICE

Ivete de Aquino Freire

Ramón Núñez Cárdenas

Marcelo Tiago Baltazar Correa

Ednes Pereira dos Santos Souza

93 4. ADOLESCÊNCIA: MANIFESTAÇÕES DE LAZER NA HISTÓRIA DE VIDA DE IDOSAS DE PORTO VELHO

Ivete de Aquino Freire

Ramón Núñez Cárdenas

Fernanda Gahu de Oliveira

Walace Henrique Reis Melo 

5. MATURIDADE: MANIFESTAÇÕES DE LAZER NA HISTÓRIA DE VIDA DE IDOSAS DE PORTO VELHO Ivete de Aquino Freire Ramón Núñez Cárdenas Rosa de Luz Ambrósio dos Reis Miranda Sá Paola Tristão de Lima

153 6. MANIFESTAÇÕES DE LAZER DE IDOSAS DE PORTO VELHO

Ivete de Aquino Freire

Ramón Núñez Cárdenas

191 Sobre os autores 


\section{APRESENTAÇÃO}

A partir de contatos informais com mulheres idosas durante viagens de lazer organizadas pelo grupo de convivência "Pioneiras de Rondônia", tivemos a oportunidade de conhecer aspectos das histórias de vida dessa população. São mulheres, predominantemente, entre a faixa etária de $70 \mathrm{a}$ 90 anos.

Durante as longas conversas nas viagens de ônibus da cidade de Porto Velho a outras localidades das distintas regiões do Brasil, puderam-se observar muitas semelhanças nas histórias de vida desse grupo etário. Nos relatos predominavam as dificuldades enfrentadas pelas senhoras, marcadas por problemas iniciados na infância, estendendo-se até a fase adulta.

Algumas afirmaram que nunca desfrutaram de momentos de lazer quando crianças, jovens e na fase madura; que somente na idade a situação

de vida foi alterada positivamente. Os cuidados com a casa, filhos, marido e a necessidade de desenvolver atividade remunerada, dentro ou fora do espaço doméstico, não permitia usufruir desse atual direito constitucional. Para sustentar os filhos ou contribuir com o marido na manutenção da casa, enfrentavam longas jornadas de trabalho desde fazer doces por encomendas, lavagem de roupa das classes mais abastadas financeiramente, trabalhos domésticos nas residências das elites da cidade, até outros labores mais "pesados" que historicamente considera-se que exigem a virilidade associada ao homem. Também se repetiu na fala das mulheres do grupo "Pioneiras de Rondônia" a vivência de que agora que se encontravam na fase idosa é que identificam com clareza seus momentos de lazer.

Com esses dados, e a partir de 2015, com o apoio financeiro do Governo Federal Brasileiro, por intermédio do Ministério do Esporte e da Secretaria Nacional de Esporte, Educação, Lazer e Inclusão Social, foi possível desenvolver um projeto que investigasse as práticas de lazer das idosas do grupo "Pioneiras de Rondônia".

Assim nasceu o projeto de pesquisa "O lazer na trajetória de vida de mulheres idosas da Amazônia Brasileira”, que resultou nesta obra. Aqui, 
o lazer de idosas na Amazônia é discutido antes mesmo da oficialização do atual Estado de Rondônia. Justifica-se este recorte metodológico pela inexistência de acervo de informações, em face da incipiência de estudos voltados ao lazer com aproximação de dados que indiquem a evolução e as diferenças de traços do comportamento sociocultural das famílias da região Amazônica.

O trabalho foi realizado por pesquisadores e estudantes do Centro de Desenvolvimento de Pesquisas em Políticas de Esporte e Lazer de Rondônia, da UNIR, vinculado à Rede CEDES do antigo Ministério do Esporte.

A principal vertente teórica que orienta a publicação é a Educação Física. Entretanto, não se limita a essa área de conhecimento, uma vez que se busca refletir também o fenômeno lazer na sua perspectiva multidisciplinar e multifatorial. Desse modo, a publicação explora o viés macro, examinando os achados, tendo como pano de fundo aspectos relativos à construção e povoamento da região e da localidade.

O livro está organizado em seis capítulos, que podem ser analisados separadamente ou interligados entre si. Cada capítulo retrata os achados de um grupo de trabalho. Como se tratou de um projeto de pesquisa do tipo "guarda-chuva", os pesquisadores foram organizados em seis grupos de trabalho, resultando, de cada grupo, os capítulos aqui apresentados. Reuniões com todos os integrantes do grupo foram realizadas periodicamente, a fim de que cada subprojeto mantivesse a coerência com o objetivo geral da pesquisa.

O primeiro capítulo, intitulado "Alguns aspectos teóricos para os estudos descritivos do lazer", faz um recorrido teórico sobre os principais conceitos e abordagens do lazer no Brasil. Também se apresentam as características das políticas públicas de esporte e lazer nesse país nos últimos anos. Os constructos apresentados são importantes na medida em que favorecem reflexão teórico-prática sobre as vivências de lazer nas distintas fases da vida das idosas.

O segundo capítulo, nomeado "A História Oral na modalidade Trajetória de Vida como proposta de produção do conhecimento em pesquisa sobre lazer", discorre sobre as características da História Oral (HO) com 
ênfase na modalidade Trajetória de Vida e sua aplicação no estudo sobre lazer das idosas de Porto Velho, Rondônia. Os constructos da HO ofereceram o embasamento metodológico para a realização da pesquisa voltada ao lazer na trajetória de vida das idosas e foram fundamentais para a compreensão das múltiplas temporalidades na história de vida das depoentes.

O terceiro capítulo, "Manifestações de lazer na história de vida de idosas de Porto Velho: da infância a meninice”, marca o início da reconstrução da trajetória de lazer das mulheres depoentes. Aqui, os achados estão dispostos em consonância com as características socioeconômicas das mulheres quando ainda eram crianças.

No quarto capítulo, avança-se para discorrer sobre o lazer das idosas durante a pré-adolescência e adolescência. Recorrendo às memórias das idosas, busca-se contextualizar o lazer em suas trajetórias de vida, em conformidade com a conjuntura socioeconômica e cultural da época.

Já o capítulo cinco versa sobre o lazer na maturidade das idosas. Nesse caso, a idade cronológica não foi o principal fator para a classificação das mulheres nessa fase da vida. O casamento, os cuidados com a casa e os filhos foram os principais definidores de entrada na fase adulta. Juntamente com esses aspectos, as duplas ou mais jornadas de trabalho delineavam o tempo disponível para o lazer.

$\mathrm{E}$, finalmente, o último capítulo recorre à memória das mulheres idosas, a fim de abordar as suas atuais vivências de lazer. Nesse caso, as falas referem-se à fase atual da vida: acercam-se do papel do SESC/RO, do grupo de convivência Pioneiras de Rondônia, os tipos de lazer que disfrutam, o papel da família nessas vivências e as principais dificuldades enfrentadas.

Organizadores 



\section{ALGUNS ASPECTOS TEÓRICOS PARA ESTUDOS DESCRITIVOS DO LAZER}

Ivete de Aquino Freire

Ramón Núñez Cárdenas

Andrea Nascimento Ewerton

\section{Introdução}

Para falar sobre trajetória de lazer das mulheres idosas, faz-se necessário compreendermos quais as possíveis concepções de lazer em que essas trajetórias podem estar apoiadas, quais as abordagens atuais sobre lazer e como esse fenômeno se insere nas políticas públicas brasileira. $\mathrm{O}$ lazer é um fenômeno multidisciplinar e multifatorial, daí a complexidade de se optar por uma única concepção e abordagem.

Considerando o exposto, este capítulo serviu de base teórica para uma compreensão do lazer das idosas que nasceram na região Amazônica ou que vieram para a localidade ainda na infância. Na perspectiva de estudar o lazer na trajetória de vida dessas mulheres (na infância, na adolescência, na maturidade e na terceira idade), os aspectos teóricos a serem apresentados aqui, juntamente com o contexto histórico econômico, social e cultural, permitiram melhor compreensão das distintas realidades investigadas. Desse modo, neste capítulo busca-se alcançar os seguintes objetivos: a) Identificar algumas contribuições para a composição dos conceitos atuais de lazer no Brasil; b) Refletir sobre as diferentes abordagens de lazer; c) Analisar aspectos relativos a políticas públicas de esporte e lazer no Brasil.

O lazer é uma temática estudada por diversas áreas de conhecimento e, por vezes, pode gerar reflexões multi e interdisciplinares (Pinheiro; Gomes, 2011). Nesse sentido, se observam inúmeras possibilidades de abordagens teórico-práticas. Apesar dessa variação, constata-se 
que os conceitos de lazer se apresentam, como não poderia deixar de ser, seguindo uma evolução histórica, entretanto, sem perder de vista as raízes teóricas de autores tradicionais.

Em estudos sobre lazer, consideramos fundamental deixar claro o conceito que se adota sobre esse fenômeno. Entretanto, essa não é uma tarefa fácil, posto que a maioria das concepções mais atuais sobre lazer são resultados da construção de vários autores ao longo de mais de quatro décadas. Assim, para delinear a concepção que se adota aqui, será feito um levantamento sobre o que consideramos os principais constructos sobre essa temática no Brasil.

A composição teórica atual do lazer no Brasil tem início com os escritos de Dumazedier, na década de 70. Para esse autor, o lazer é um conjunto de ocupações, às quais o indivíduo pode entregar-se de livre vontade, seja para repousar, seja para divertir-se, recrear-se e entreter-se, informar-se ou desenvolver formação desinteressada. Implica participação social voluntária ou livre capacidade criadora, após livrar-se ou desembaraçar-se das obrigações profissionais, familiares e sociais. Tem como função importante a tentativa de fazer que o indivíduo se desligue temporariamente de suas obrigações (Dumazedier, 1994, 2001). Apesar do valor dos escritos de Dumazedier no contexto brasileiro, sua concepção deixa margem para uma perspectiva de lazer como mero entretenimento ou compensação do trabalho, compreendido por Marcellino como uma concepção conservadora e funcionalista (Marcellino, 1995). A visão funcionalista de lazer, que determina o papel compensatório dessa prática, prega a continuidade da ordem social pré-estabelecida e, ao mesmo tempo, situa o lazer como uma válvula de escape dessa ordem vigente.

A partir de meados da década de 1980, com os escritos de Marcellino (1990), pode-se visualizar um sentido mais amplo de lazer. O autor agrega quatro aspectos importantes para a compreensão desse fenômeno, que posteriormente serão acompanhados e aprofundados por outros pesquisadores. O primeiro aspecto diz respeito ao que o autor denomina "traço definidor das vivências de lazer”. De acordo com Marcellino, um traço definidor do lazer é o seu caráter desinteressado. Essa característica adquire importância 
na definição de lazer na medida em que o que se busca com essa prática é o lazer em si ou a satisfação provocada pela situação ou vivência.

O segundo aspecto agregado por Marcellino para uma ampla compreensão de lazer é a fluidez dessa vivência no decorrer de um denominado "tempo disponível" (Marcellino, 1987). Para o autor, o lazer ligado ao aspecto tempo considera as atividades desenvolvidas no tempo liberado do trabalho, ou no tempo livre ou disponível, não só das obrigações profissionais, mas também das familiares, sociais e religiosas (Marcellino, 2000).

Um terceiro marco identificador reside na compreensão do lazer como cultura e como fenômeno social. Para o autor, lazer é uma criação cultural e, portanto, um fenômeno social, que dialoga com a sociedade e possibilita o surgimento de valores questionadores que vislumbram mudanças (Marcellino, 1987). Com esse autor, se observa o uso do termo "lazer" como forma de expressão humana (Marcellino, 2000), denominação adotada por outros pesquisadores.

Com a afirmativa de que o lazer pode ser entendido como fenômeno social, Marcellino (1995) sinaliza o que denominamos aqui a sua quarta contribuição na composição dos pressupostos teóricos atuais sobre o lazer. Estamos fazendo referência à compreensão de que as vivências de lazer podem potencializar o desenvolvimento pessoal e social. Segundo o autor, no lazer há:

[...] potencialidades para o desenvolvimento pessoal e social dos indivíduos. Tanto cumprindo objetivos consumatórios, como o relaxamento e o prazer propiciados pela prática ou pela contemplação, quanto objetivos instrumentais, no sentido de contribuir para a compreensão da realidade, as atividades de lazer favorecem, a par do desenvolvimento pessoal, também o desenvolvimento social, pelo reconhecimento das responsabilidades sociais, a partir do aguçamento da sensibilidade ao nível pessoal, pelo incentivo ao auto aperfeiçoamento, pelas oportunidades de contatos primários e de desenvolvimento de sentimentos de solidariedade (Marcellino, 1995, p. 60). 
Como se pode observar, com relação ao lazer como expressão da cultura, Marcellino, há mais de duas décadas, já considerava que o valor cultural dessa atividade está ligado, duplamente, ao nível alcançado pelo indivíduo tanto pela prática em si quanto pelo consumo. Da análise dessas duas variáveis, suscitam as categorias "participação", como fenômeno relacionado à primeira variável, e "passividade", relacionada ao consumo. Destaca o autor que a simples prática não significa participação, assim como nem todo "consumo" corresponde necessariamente à passividade. Por outro lado, a atividade de lazer não é ativa ou passiva. Um ou outro conceito refere-se à atitude do praticante que atribui uma qualificação ao seu lazer. Dependendo dos níveis de participação, a pessoa pode ser ativa ou passiva (Marcellino, 1987). Complementa ainda o autor afirmando que as manifestações de lazer, como fenômeno criado historicamente, provocam o surgimento de valores e ao mesmo tempo sofrem as influências da estrutura social vigente (Marcellino, 1995). Nas palavras de Gomes, Pinheiro e Lacerda (2010, p.15):

[...] lazer é um fenômeno dinâmico, apresentando tanto características que podem reforçar a ordem social quanto possibilitar a criação de algo novo e a transformação da sociedade, tornando-a mais justa e humanizada.

Além de apresentar o lazer como prática cultural, outra contribuição expressiva de Marcellino nos constructos atuais sobre o lazer no Brasil é a vinculação entre lazer e cidadania. Segundo o autor, a prática consciente e ativa de lazer proporciona a possibilidade de as pessoas exercerem a plena cidadania. Desse modo, essa prática cultural se configura como espaço questionador dos valores da sociedade, visando modificações no quadro social (MARCELLINO, 1995).

Com seus escritos, Marcellino contribui significativamente para a atual composição teórica do lazer, uma vez que permanece sendo uma referência importante no cenário contemporâneo sobre esse conceito no Brasil.

Seguindo e detalhando as ideias de Marcellino, em meados da década de 1990, dois autores se destacam na composição teórica do lazer 
no Brasil: Oliveira e Brunhs. Com Oliveira (1997), vislumbra-se pela primeira vez a interpretação do lazer como uma prática que pode favorecer o questionamento. Ao citar Lefebvre, o autor analisa o lazer na vida cotidiana e pontua que, com essas práticas e por meio delas, os homens podem elaborar críticas à sua vida cotidiana. Entretanto, destaca também, orientado pelo mesmo autor, que a superação de problemas, papel atribuído ao lazer, não necessariamente ocorre. Os pressupostos apontados por Oliveira (1997) nos remetem aos escritos de Marcellino (1995), pois entendemos que questionamentos e críticas do cotidiano são aspectos fundamentais para a ocorrência de desenvolvimento pessoal e social. Ou, dito de outra forma, o desenvolvimento pessoal e social é potencializado por meio de questionamentos e críticas.

Bruhns (1997), em contribuição, destaca que as necessidades humanas vão além da compensação, uma vez que envolvem conhecimento, descoberta e convívio, entre outros aspectos. Com essa visão, o autor afirma que o lazer é uma necessidade humana.

Além do dito anteriormente, Oliveira (1997) também aborda a temática do "tempo disponível" no contexto do lazer, mencionando esse "tempo" como ruptura em relação ao tempo de trabalho. Nessa reflexão, Bruhns (1997) cita que o "tempo livre" significa livre das obrigações sociais, profissionais, afazeres domésticos, entre outras atividades cujos condicionantes estejam relacionados a fatores socioeconômicos. Cita Werneck (2003) que o fator tempo foi considerado no século XIX um aspecto importante na concepção de lazer. Essa prática passou a ser compreendida como tempo subtraído do trabalho; um tempo excedente, residual, preenchido com propostas capazes de, simultaneamente, recrear, relaxar e educar o operário que recuperava, assim, as energias despendidas no exercício laboral.

Pinto (2001) destaca que a atitude lúdica, o tempo e o espaço são alguns dos fatores que possibilitam ao sujeito viver o lazer. Complementa Gomes $\left(2008^{\mathrm{b}}\right)$, mencionando que a atitude lúdica, espaço e lugar, na vivência de determinadas manifestações culturais, compõem os conteúdos do lazer. Esse espaço-lugar vai além do espaço físico, já que se trata de um "local" do qual os sujeitos se apropriam, no sentido 
de transformá-lo em ponto de encontro (consigo, com o outro e com o mundo) e de convívio social para o lazer.

Marcellino, Oliveira e Bruhns formam um grupo de autores que servem de base para as composições atuais de lazer, sendo o primeiro a principal referência. Com esses autores, constatou-se a superação da visão reduzida de lazer apenas como atividade de compensação ou prática casual. Desse modo, averígua-se que, além de o lazer proporcionar a recuperação da força/energia dispendida ao trabalho, e de trazer respostas à fadiga, às tensões, às inquietações inerentes à vida cotidiana, essa prática também, e, sobretudo, responde a necessidades sociais específicas, pois não se limita ao mundo do trabalho, mas envolve os demais repertórios de atividades sociais. Ao que chamamos aqui de visão reduzida de lazer, Marcellino (1995) denomina "abordagem funcionalista". Essa classificação decorre do fato de que, nesse caso, os pressupostos que dão suporte à interpretação de lazer têm por base uma visão utilitarista, e os valores se enquadram numa tendência conservadora (Marcellino, 1995).

Com Werneck (2003), seguida por outros autores, observa-se mais um salto qualitativo nos estudo do lazer. Para a autora, o lazer é uma dimensão da cultura, em tempo e espaço, composto por conteúdos culturais pautados na ludicidade. Lazer é:

[...] uma das dimensões da cultura socialmente construída a partir das ações, do tempo, do espaço/lugar e dos conteúdos culturais vivenciados, ludicamente, pelos sujeitos. Constituído conforme as peculiaridades do contexto histórico no qual se desenvolve, o lazer implica em produção de cultura - no sentido da reprodução, construção e transformação de diversos conteúdos culturais usufruídos por parte de pessoas, grupos e instituições. Essas ações são construídas em um tempo/espaço de produção humana; dialogam e sofrem interferências das demais esferas da vida em sociedade, e nos permitem ressignificar, continuamente, a cultura (Werneck, 2003, p. 37).

Complementa Gomes (2004): o lazer é uma dimensão da cultura constituída pela vivência lúdica de manifestações culturais no tempo/ 
espaço conquistado pelo sujeito ou grupo social, estabelecendo relações dialéticas com as necessidades, os deveres e as obrigações, especialmente com o trabalho produtivo. Assim, sem perder de vista o marco conceitual dos autores que a antecederam, Gomes (2004 $)$, reforça que o lazer deriva de manifestações vivenciadas, flui da cultura, seja como possibilidade de diversão, seja de descanso ou de desenvolvimento. Segundo a autora, o que diferencia esse fenômeno cultural das demais realizações humanas é a sua essência lúdica. O lazer é:

[...] expressão humana de significados da/na cultura referenciada no brincar consigo, com o outro e com o contexto. Por essa razão, o lúdico reflete as tradições, os valores, os costumes e as contradições presentes em nossa sociedade. Assim, é construído culturalmente e cercado por vários fatores: normas políticas e sociais, princípios morais, regras educacionais, condições concretas de existência (Gomes, 2004 , p. 145).

Gomes $\left(2004^{\mathrm{b}}, 2008^{\mathrm{a}}\right)$ contribui com a apresentação de quatro elementos inter-relacionados que abrangem o lazer: (1) tempo, usufruto do momento presente e não apenas os períodos institucionalizados ao lazer; (2) espaço / lugar, por ir além do espaço físico, mas um "local" que o sujeito transforma em ponto de encontro para o convívio social; (3) manifestações culturais que representam as práticas vivenciadas como resultado da cultura e detêm significados peculiares para quem as vivencia; e (4) atitude, fundamentada naludicidade, representada como expressão humana de significados na cultura referenciada no brincar consigo, com o outro e com a realidade.

Werneck e Isayama (2001) e Werneck (2003) seguem de perto alguns pontos delineados em publicações de Marcellino, investindo, porém, no seu aprofundamento. Adotam a dimensão cultural do lazer e compreendem esse fenômeno como produção humana de ressignificação constante, ao reconhecer a presença de certos significados, valores, normas e jeitos de ser nas manifestações de lazer. As vivências entranhadas nas atividades são expressões humanas e formas de intervir no mundo e não somente uma parcela de tempo, uma coisa ou uma mercadoria. Nas práticas de lazer, os 
sujeitos não são "meros objetos desprovidos de histórias de vida particulares e que ignoram as questões culturais, políticas e sociais mais amplas que os constituem" (Werneck, Isayama, 2001, p. 65).

Com Alves e Isayama (2006), deparamos com a superação dos escritos de Dumazedier, quando afirmam que no lazer se imprimem importantes significados sociais e se estabelecem relações com o trabalho ou o tempo de não trabalho. Para as autoras, o lazer não é mero acessório do trabalho, mas um potencializador de acesso à dimensão da cultura, inclusive da cultura do trabalho. Nesse sentido, Gomes, Pinheiro e Lacerda (2010) destacam que o lazer representa "uma possibilidade de mobilização e engajamento político, facilita a criação de redes de sociabilidade e estimula a reflexão sobre nossa sociedade [...]” (p. 21).

Considerando os conceitos de lazer disponibilizados na literatura atual, Gomes, Pinheiro e Lacerda, (2010, p. 22) averiguaram a presença de ambiguidade ou contradições, além da presença de elementos que restringem uma compreensão satisfatória desse fenômeno. A partir daí, novos conhecimentos foram agregados, gerando o que Gomes (2008 $)$ chama de variabilidade conceitual. Apesar dessa variabilidade, as autoras destacam uma tendência em considerar uma dimensão cultural no lazer.

Baseados em outros estudos, Gomes, Pinheiro e Lacerda (2010, p. 16) asseveram que:

[...] o lazer representa um fenômeno sociocultural que se manifesta em diferentes contextos (histórico, social, político, etc.) de acordo com os sentidos/significados que são produzidos e reproduzidos por meio das relações dialéticas dos sujeitos nas suas relações com o mundo.

Estudos de Cuenca Cabeza (2016) vêm ocupando espaço de destaque nas publicações brasileiras. O autor fala sobre o lazer como ócio autotélico. Essa terminologia aproxima-se do conceito de experiências autotélicas estudadas na teoria do fluxo. Estudos de Csikszentmihalyi (apud Nunes e Hutz, 2014) indicam que fluxo é um estado no qual as pessoas estão tão envolvidas e concentradas no que fazem que nada mais parece importar. 
Isso ocorre porque a experiência em si é tão prazerosa que, mesmo quando há um grande prejuízo, não se abre mão de fazê-la. Nas situações de fluxo, as experiências tornam-se autotélicas, ou seja, vale a pena fazer a atividade por ela mesma; não há uma motivação externa ou objetivo utilitário (Rhoden apud Nunes e Hutz, 2014).

Nunes e Hutz (2014), considerando a teoria do fluxo e relacionando-a com os aportes sobre o lazer, afirmam que as experiências de lazer têm motivação intrínseca e, quando se tornam fluxo, podem estimular o bemestar e aumentar as emoções positivas.

O ócio autotélico se sustenta em três pilares essenciais: livre escolha, fim em si mesmo (autotelismo) e sensação gratificante. Envolve o compromisso que o indivíduo assume com o lazer, a partir do momento que admite o caráter diferencial dessa prática e ingressa em um processo consciente de desenvolvimento. Argumenta ainda o autor que o ócio autotélico se diferencia dos demais tipos de ócio pelas dimensões lúdica, ambiental-ecológica, criativa, festiva e solidária. Os pressupostos teóricos de Cuenca Cabeza aproximam-se dos conceitos de Gomes, Pinheiro e Lacerda; Werneck e Isayama; Marcellino e outros brasileiros mencionados anteriormente. A diferença principal reside em que estes últimos abordam o lazer diretamente como um elemento importante para a consolidação da cidadania, sendo o lazer considerado como preceito básico para uma vida digna.

Com base nas distintas contribuições apresentadas e na convergência entre as visões do lazer como manifestação cultural, conclui-se que esse fenômeno tem alguns traços que o definem. Entre esses traços se encontram "uso do tempo livre das obrigações profissionais, familiares e sociais", "liberdade na sua prática", "diversão", "recreação", "entretenimento", prazer e satisfação. Tais conceitos são imprescindíveis diante de alguma tentativa de compreender esse fenômeno. Considera-se que não existe qualquer hierarquia entre eles, já que é a junção de todos que permite uma compreensão do lazer.

Por outro lado, sem compor os traços definidores, diferentes variáveis, tais como "criticidade", "cidadania" e "desenvolvimento pessoal", emergiram da palavra lazer como manifestação cultural, consolidando os constructos teóricos atuais. Entendemos que esses conceitos atribuem valor 
à prática, uma vez que nos remetem para uma abordagem da qualidade do lazer. Assim, para qualificação dessa atividade, é necessário considerar as especificidades concretas do lazer, tal como cita Marcellino (2007, p.13). Para o autor, considerar tais especificidades significa levar em conta os conteúdos do lazer, as atitudes que envolvem a prática, os valores que propiciam a consideração dos seus aspectos educativos, as suas possibilidades como instrumento de mobilização e participação cultural, e as barreiras socioculturais verificadas para seu efetivo exercício. E mais, o autor afirma categoricamente que o lazer pode constituir-se tanto em elemento de conformismo como de resistência à ordem social estabelecida, e que existem práticas de lazer mais comprometidas com o desenvolvimento pessoal e social e outras menos comprometidas (Oliveira, 1997).

Nos dizeres de Marcellino (2000) e Werneck (2003), constata-se que as manifestações de lazer estão condicionadas a alguns fatores que simultaneamente são também barreiras que impedem o efetivo exercício dessa expressão humana. Considerando o lazer como um fenômeno social, entre os condicionantes se destacam: o nível socioeconômico e nível de instrução, religião, a faixa etária, gênero, cultura e conteúdos oferecidos.

Finalmente, para encerrar este ponto, ressalta-se que o emprego da expressão "esporte e lazer", utilizada neste trabalho, decorre da opção de seguir a nomenclatura oficial utilizada no âmbito das políticas de Governo. Nesse caso, o termo "esporte" que acompanha a palavra "lazer" envolve atividades físico-esportivas, especificamente recreativas. Reconhece-se aqui, conforme orienta Castellani Filho (2007), que se trata de conceitos distintos, mas quando o termo "esporte" acompanha a palavra "lazer", se tornam termos confluentes, na medida em se está fazendo referência à dimensão recreativa do esporte.

\section{Distintas abordagens de lazer}

O campo de conhecimento sobre o lazer é bastante complexo e tem sido objeto de estudo de diversas áreas do conhecimento. Dentre essas áreas, destacamos a Sociologia, Psicologia, Educação, Economia e Saúde. 
Os estudos sobre o lazer conquistaram forças mediante as demandas político-sociais do trabalho, sobretudo nas sociedades capitalistas, no momento em que se passou a discutir e valorizar a saúde do trabalhador (Baldisserai; Bueno, 2012).

Pontua Bruhns (1997) que a articulação lazer e trabalho decorrem essencialmente no processo de industrialização, quando se estabelece uma organização mais racional e produtiva do trabalho. Isso porque a intensificação da produção e, por consequência, o aumento de mão de obra arrastam a necessidade da recuperação mais rápida dos trabalhadores. Parte-se do princípio de que todo o trabalho veicula, implicitamente, um custo humano, que impacta negativamente no âmbito psicossocial, gerando a necessidade de uma compensação ou recuperação via vivências de prazer. Diferente da realidade anteriormente descrita, segundo Bruhns (1997), no Brasil, o processo de urbanização foi o principal elemento desencadeador do fenômeno denominado lazer. Com essas considerações iniciais, pode-se compreender que os primeiros escritos sobre lazer têm amparo na vertente sociológica.

Destacam Gomes, Pinheiro e Lacerda (2010) que um dos conceitos de lazer que mais tiveram repercussão no Brasil, na década de 1970, foi aquele elaborado pelo sociólogo francês Jofre Dumazedier. Com esse autor, ao lazer se imprimem importantes significados sociais e se estabelecem relações com o trabalho ou o tempo de não trabalho.

Com os impactos sociais do lazer, com destaque para o bem-estar dos indivíduos, no Brasil essa prática passou a ser um direito constitucionalmente posto. A perspectiva sociológica de Dumazedier ampara teoricamente esse direito. $\mathrm{O}$ autor apresenta o lazer com três importantes funções: o divertimento, o descanso e o desenvolvimento pessoal. Considerando essas funções, vivências de lazer são orientadas para a realização da pessoa como fim último (Dumazedier apud Nunes; Hutz, 2014).

Ainda seguindo a vertente sociológica, Sampaio e Silva (2011), orientados pelos estudos de Dumazedier, citam que o lazer está ancorado em quatro propriedades: o caráter libertário, desinteressado, hedonístico e pessoal. O caráter libertário envolve a compreensão de que o lazer é uma 
prática de livre escolha, liberada de obrigações institucionais, profissionais, familiares, sociopolíticas e socioespiritual. $\mathrm{O}$ caráter desinteressado destaca que o lazer não tem nenhuma motivação lucrativa ou utilitária, mas o seu fim é a satisfação que a atividade em si proporciona. Já o caráter hedonístico revela a busca do prazer, alegria e felicidade. Por fim, no que tange ao caráter pessoal, destaca-se que as funções expressas pelas atividades de lazer respondem às necessidades individuais.

O sociólogo Renato Requixa, seguindo a linha de pensamento de Dumazedier, definiu o lazer como uma ocupação sem obrigatoriedade, escolhida livremente pelo indivíduo, proporcionando-lhe recuperação, desenvolvimento pessoal e social. Esse autor contribuiu de forma positiva no desdobramento do pensamento sobre essa temática no Brasil, enfatizando a importância do tempo livre para o desenvolvimento do lazer e do homem (Requixa apud Aquino; Martins, 2007).

Ainda na perspectiva sociológica, De Masi (apud Nunes; Hutz, 2014) pontua que o trabalho é um elemento limitante do lazer, pois invade o tempo livre e priva as pessoas dos prazeres das vivências desse tempo. Cita o autor que o ideal é buscar um equilíbrio entre as atividades de trabalho, estudo e lazer, por meio de uma redução da jornada de trabalho. O autor defende que o ser humano deve ser poupado do trabalho repetitivo, incumbindo esse trabalho às máquinas. Ao homem cabe o "ócio criativo", ou seja, a capacidade de pensar, de refletir e de criar.

Pinto (2001) defendeu que o lazer com valores compensatórios é entendido como possibilidade de realização individual, em oposição à alienação e à insatisfação que o trabalho produz no indivíduo moderno. Essa alienação, entre outros fatores, decorre do trabalho mecânico, fragmentado e especializado. Marcellino (1995) cita que o lazer, nessa perspectiva, configura-se como um mecanismo que poderia reparar o dano que o trabalho produz no indivíduo, servindo à manutenção do quadro social. Reforça o autor que, ao reduzi-lo à função de recuperação da força de trabalho, o lazer assume fins utilitaristas.

$\mathrm{E}$, finalmente, outra linha de raciocínio que fortalece a vertente sociológica do lazer refere-se ao fato de que, ao participar de algumas 
atividades de lazer, os indivíduos criam ou fortalecem os grupos sociais, ao mesmo tempo que se consolidam como integrantes desses grupos.

Segundo Rios et al. (2011), no círculo social, os indivíduos promovem sua autoestima ao mesmo tempo que exercitam a sociabilidade e evitam o seu isolamento social. Reforça essa questão o estudo realizado por Baldisserai e Bueno (2012). Os autores verificaram que o lazer, vivenciado por mulheres hipertensas, é uma forma de enfrentar a solidão e favorecer a socialização e o contentamento pela vida.

Orientados por publicação de Ponde, complementam Baldisserai e Bueno (2012): as atividades socializantes de lazer são também desencadeantes de saúde. Com esta última afirmação, constata-se que as abordagens de lazer não são estanques, mas, ao contrário, se complementam. Nesse caso, observam-se as abordagens sociológica e de saúde simultaneamente, no mesmo delineamento sobre lazer.

No âmbito da Psicologia, o lazer é analisado considerando os efeitos psicólogos advindos dessa prática. Daí, Nunes e Hutz (2014) conceituarem lazer na perspectiva psicológica como a satisfação de uma necessidade humana complexa, que é colocada em prática por meio de experiências que são individualmente definidas como prazerosas.

Iwanowicz (1997), ao detalhar essa necessidade humana, orientado pelos estudos de diversos autores, afirma que do ponto de vista psicológico o lazer apresenta múltiplas funções que variam de um autor para outro. Para Lipinski (apud Iwanowicz, 1997), as funções do lazer são: educativa, ensino, integrativa, recreativa, cultural, compensatória. De acordo com os autores, a função educativa se caracteriza pelo lazer dirigido para a ampliação dos horizontes mentais. Abrange, por exemplo, o desenvolvimento psicológico da consciência de poder dispor livremente de tempo para o lazer como a realização de uma necessidade pessoal de expressar-se, de realizar a sensação de liberdade de escolha, de atuação e de atitude. A função de ensino do lazer envolve a assimilação ou aprendizagem de normas culturais, de ideais filosóficos ou políticos, normas de convivência social ou de comportamento. A função integrativa abrange a criação ou consolidação dos grupos sociais, envolvendo integrantes de interesses comuns. A função 
recreativa envolve as atividades relacionadas com o descanso psicológico e físico. Essas vivências resultam em relaxamento e diminuição da tensão nervosa quando produzem sensação de satisfação e contentamento. Já a função cultural abrange a compreensão e assimilação de valores culturais historicamente acumulados ou a criação de novos valores. E, finalmente, a função compensatória compreende o nivelamento das insatisfações das outras áreas da vida, nas quais não se pode desfrutar de vivências de lazer. Trata-se da compensação causada pela monotonia de outras atividades, tais como o trabalho, por exemplo. Com essa função, o lazer produz descarga e elimina o cansaço psíquico, as tensões e o estresse.

Roykiewicz (apud Iwanowicz, 1997) nomeia as seguintes funções do lazer: psicorrecreativa, psicocompensatória, psicocorretiva e psicocriativa. A função psicorrecreativa atua na regulação e diminuição do esforço psicológico que pode levar a casos extremos de tensão emocional, estresse e de psiconeurose reativa. A função psicocompensatória refere-se ao nivelamento da "falta de algo, de compensação de potencial energético de aspirações, desejos, planos específicos para cada indivíduo" (Iwanowicz, 1997, p. 97). Reforça o autor que essa função busca satisfazer as necessidades psicológicas essenciais que se formam ao longo da vida. Essas necessidades a serem satisfeitas não necessariamente foram bloqueadas ou frustradas; podem ser, portanto, novas necessidades geradas.Já a função psicocorretiva compreende "uma atuação psicológica que ajuda a eliminar ou diminuir a intensidade ou frequência dos comportamentos indesejáveis socialmente através de situações corretivas" (Iwanowicz, 1997, p. 98). Cita o autor que essa função abrange as psicoterapias leves, trabalhos de reabilitação e reeducação, entre outras. E, finalmente, a função psicocriativa refere-se à formação dos valores externos relacionados com a expressão da personalidade e dos valores internos, incluídos nos processos de auto realização e auto perfeiçoamento. Complementa o autor que essa função ativa outros processos importantes para o desenvolvimento das pessoas, tais como a atuação reflexiva sobre si mesmo e a contemplação dirigida para a beleza da natureza e da arte, entre outros aspectos. O turismo ecológico, histórico ou cultural são vivências que potencializam essa função do lazer, conforme menciona o autor. 
Iwanowicz (1997), ao abordar as funções do lazer, parece contrariar o que foi dito por Marcellino (1990) e seguido por diversos autores sobre o caráter desinteressado dessa prática, cujo objetivo é a vivência em si; ou a satisfação provocada pela situação vivida. Por outro lado, os escritos de Iwanowicz (1997), orientados pela vertente psicológica, se identificam: a) com a abordagem do lazer pelo viés da educação, em especial da educação pelo lazer ao mencionar que essa prática contribui para a eliminação ou diminuição dos comportamentos indesejáveis socialmente através de situações corretivas; b) com a matriz sociológica ao mencionar o lazer como recurso compensatório da monotonia de outras atividades, com função de eliminar o cansaço psíquico, as tensões e o estresse do dia a dia e ampliar normas de convivência social ou de comportamento; e c) com a abordagem da saúde ao afirmar que o lazer tem função de prevenção de casos extremos de tensão emocional, estresse e de psiconeurose reativa.

Inspirados por Witt e Bishop e sem divergir de nenhum dos autores citados anteriormente, Nunes e Hutz (2014) pontuam que as práticas de lazer variam de indivíduo para indivíduo, pois são orientadas pelos recursos individuais disponíveis, objetivando a satisfação das necessidades pessoais. A escolha será de acordo com o sistema de valores e aspirações pessoais. $\mathrm{O}$ caráter de "lazer" da atividade não tem origem na atividade em si, mas no significado que a pessoa confere a essa atividade. Por esse motivo, o que é lazer para uma pessoa pode não ter o mesmo significado para outra. Ocorre que nem todas as atividades de lazer são saudáveis; algumas (consumo de drogas e aqueles que envolvem atitudes de violência, por exemplo) podem oferecer riscos psicossociais aos praticantes e a outras pessoas.

Formiga (apud Nunes; Hutz, 2014) desenvolveu estudos em que estabelece associação entre lazer e condutas desviantes em jovens. $\mathrm{O}$ autor investigou que hábitos de lazer hedonistas (com características egoístas e individualistas) associam-se positivamente a condutas desviantes e antissociais; ao mesmo tempo, hábitos de lazer instrutivos e lúdicos associam-se negativamente a essas condutas.

Conforme estudos de Iwanowicz (1997) e Formiga (apud Nunes; Hutz, 2014), a Psicologia, como área de conhecimento que trata do 
comportamento do ser humano e de suas interações com um ambiente físico e social, se apropria do lazer no sentido de intervir em práticas nocivas aos indivíduos e para a sociedade; e, ao mesmo tempo, fomentar a reflexão de práticas saudáveis. Dito conforme Aquino e Martins (2007): atividades de lazer podem trazer consequências positivas ou negativas para as pessoas; podem desenvolver seus potenciais e aumentar seu bem-estar, ou ser alienante, não contribuindo para o desenvolvimento pessoal. Essa visão aproxima-se ao que Marcellino (1995) denominou "abordagem moralista" das vivências de lazer. De acordo com o autor, essa abordagem tem origem na classificação das vivências de lazer entre boas e más em suas relações com a moderna sociedade. Nesse caso, o lazer adota a função de redução dos problemas sociais e segurança da sociedade.

Finalizando esse ponto, pode-se dizer que os pressupostos da abordagem psicológica de lazer aproximam-se muito das vertentes sociológica, educacional e de saúde, podendo inclusive promover confusão entre essas vertentes. Todas elas tratam as vivências de lazer como oportunidades para o desenvolvimento pessoal e social, mas não obrigatoriamente, conforme estudos de Formiga (apud Nunes; Hutz, 2014) comentados anteriormente.

Atualmente a abordagem educacional do lazer tem possibilidades de seguir em duas direções distintas, mas podem ser complementares: educação para o lazer e educação pelo lazer. No primeiro caso, a educação é um espaço em que se criam condições para substituir momentos de tédio por práticas de lazer saudáveis e compatíveis com o desenvolvimento pessoal e social; enfim, a preparação para o tempo de lazer, que envolve o estímulo a hábitos instrutivos e lúdicos.

Cita Stigger (2009) que a abordagem educacional do lazer pode articular essa prática tanto na perspectiva de educação formal como informal, mas principalmente esta última, tendo em vista tratar-se de um processo que ocorre na vida cotidiana, no âmbito familiar, igreja, clube, entre outros ambientes.

Pela ótica da educação pelo lazer, essa prática é vista como uma vivência que contribui para o pleno desenvolvimento da pessoa, seu preparo para o exercício da cidadania. O lazer visto por essa vertente é 
sustentado pelos escritos de Marcellino (2000), Werneck (2003), Gomes, Pinheiro e Lacerda (2010) e outros autores. Nesse processo educacional, um agente importante é o animador cultural. Segundo Stigger (2009), um dos movimentos de intervenção no campo do lazer envolve a ação do animador cultural como o profissional que contribui para a realização de práticas de lazer críticas, criativas, reflexivas e libertárias. Parece que a presença da intervenção pedagógica de um profissional que utiliza o lazer como um instrumento para alcançar objetivos educacionais é a principal característica dessa vertente do lazer.

Em reflexão a essas duas possibilidades educativas do lazer, segundo Pinto (2008), pode-se afirmar que a construção conceitual atual do lazer compreende a superação da compreensão dessas práticas como preenchimento do tempo ocioso das pessoas; e avança para o entendimento de uma ação que influi na constituição de identidades individuais e coletivas, ao tempo que contribui para o desenvolvimento humano.

Numa visão distinta da apresentada anteriormente, Marcellino (2008) destaca que o lazer deve ser levado em conta pelo seu duplo aspecto educativo, que envolve tanto o desenvolvimento pessoal como o desenvolvimento social, além do descanso e divertimento. A postura de Marcellino (2008) é acompanhada por Silva e Isayama (2017). As autoras referenciam que pensar o aspecto educativo do lazer pode sinalizar a instrumentalização dessa vivência em duas direções: desenvolvimento ou apropriação do lazer como objeto dos processos educativos. De acordo com as autoras, o lazer para o desenvolvimento, anuncia uma abordagem funcionalista/utilitarista dessa prática. Essa reflexão tem amparo na interpretação de que o lazer é visto como uma ferramenta para a satisfação individual e para compensar as forças do trabalho. Ressaltam ainda as autoras que essa percepção empobrece as perspectivas educacionais do lazer cujo potencial é ilimitado. Essa condição aproxima-se aos estudos de Dumazedier (1994) que compreende o lazer com as propriedades de caráter libertário, desinteressado, hedonístico e pessoal; ao escritos de Cuenca Cabeza (2016) quando afirma que o ócio autotélico se sustenta nos pilares da livre escolha, do fim em si mesmo (autotelismo) e da sensação gratificante; 
Apoiados em Bracht, autores como Silva e Isayama (2017) pontuam que o lazer, como objeto do processo de aprendizagem, supera a dicotomia lazer/ trabalho e avança no sentido de compreender esse fenômeno com base nas manifestações e produções culturais e de outras possibilidades de vivências corporais e de educação das sensibilidades. No dizer de Melo (apud Silva; Isayama, 2017), o lazer, analisado como objeto educacional, resume o compromisso político-pedagógico da educação para e pelo lazer.

Entendendo a educação como um processo de socialização dos indivíduos numa dada sociedade, conforme menciona Stigger (2009), o lazer como conteúdo e objeto educacional contribui na aprendizagem dos padrões de comportamento, das normas, de valores e crenças sociais.

A abordagem econômica do lazer encontra amparo e se fortalece na sociedade capitalista de acordo com os diferentes tipos de lazer e suas formas de consumo. Cita Taschner (2000) que a maioria das atividades de lazer é, hoje, mediada pelo mercado, que marca a dimensão de consumo dessas práticas, engendradas na cultura contemporânea do consumo.

Segundo a autora,

A cultura do consumo abrange todo um conjunto de imagens, símbolos, valores e atitudes que se desenvolveram com a Modernidade, que se tornaram positivamente associados ao consumo (real ou imaginário) de mercadorias e que passaram a orientar pensamentos, sentimentos e comportamentos de segmentos crescentes da população do chamado Mundo Ocidental (Taschner, 2000 p. 39).

A Economia se apropria dos conhecimentos sobre lazer na medida em que essa vivência passa a ser vista como um negócio ou um serviço a ser vendido. Nessa abordagem, predomina a ideologia capitalista, que é a lógica dominante do desenvolvimento econômico no qual o lazer não só vincula-se a questão econômica, mas depende dela.

A constante expansão do processo de mercantilização do lazer reforça na nossa sociedade o que afirmaram Marcellino (2000) e Werneck (2003): o nível socioeconômico dos indivíduos é um dos condicionantes 
das vivências de lazer. $O$ mercado, vislumbrando o lucro, não só busca atender a satisfação de algumas necessidades dos clientes, mas também gera novas necessidades. Seguindo o dizer de Guimarães (apud Ramos; Isayama, 2009), destaca-se que as estratégias de marketing desenvolvidas em torno da oferta dessas atividades têm grande possibilidade de afetarem as práticas ou as vivências de lazer. Reforçam essa questão Oliveira e Freitas (2004, p.49). Para os autores,

Hoje, descansar não mais condiz com esse conceito de lazer; o tempo, todos os meios de comunicação de massa estimulam os cidadãos a trocar o antigo repouso por um momento de consumo supostamente mais emocionante e prazeroso. A satisfação via consumo de bens de lazer se dá pelas emoções proporcionadas pelo mundo dos objetos e das fantasias.

Citam Oliveira e Freitas (2004) que o leque de possibilidades em parques temáticos, ilhas paradisíacas, esportes radicais e festas intermináveis são serviços de lazer comercializados. Os empreendimentos com fins lucrativos vão se ampliando e o lazer vai se fortalecendo cada vez mais como mercadoria e objeto de consumo.

Conforme estudos de Dumazedier, citados anteriormente, entre as funções do lazer estão o divertimento, a recreação e o entretenimento. Essas afirmações estão em sintonia com a melhoria e/ou manutenção da saúde e prevenção de doenças. Evidências científicas têm demonstrado que atividades de lazer promovem sensações de bem estar, oferecendo benefícios à saúde física e mental. Desse modo, formaliza-se mais uma abordagem do lazer, dessa vez na vertente da saúde.

No âmbito da saúde física, por questões lógicas, destaca-se a necessidade de que as vivências de lazer devem ser do tipo atividades físicas (a exemplo das físico-esportivas), considerando que estas, como toda movimentação corporal, implicam gasto de energia.

Uma pesquisa bibliográfica de Silva et al. (2017), referente às publicações do período de 2010 a 2015 sobre a tríade atividades físi- 
cas/lazer/saúde, mostrou que um significativo número de estudos aborda os benefícios orgânicos da prática de atividade física de lazer. Dentre os benefícios destacados estão as melhorias com relação ao funcionamento fisiológico do corpo, de modo a evitar doenças ou o uso de medicamentos regularmente. Os autores citam que, em todos os artigos pesquisados, a atividade física de lazer aparece intimamente relacionada à noção de bem-estar.

Uma publicação de Bacheladensk e Matiello Júnior (2010) discorre que, embora inúmeros estudos abordem a importância da relação Lazer e Saúde, a temática é explorada de forma superficial, carecendo de reflexão crítica. De acordo com os autores, predominam abordagens que tratam o fenômeno lazer como um direito e uma necessidade fundamental da humanidade, que se explica por si só. Dos 95 estudos analisados que mencionavam essa relação, apenas um discutia o lazer com o aprofundamento necessário, anunciando avanços teóricos e práticos para a área. Os demais trabalhos se limitavam a mencionar o termo lazer como uma necessidade à saúde e à qualidade de vida, sem o devido aprofundamento teórico.

Com referência a doenças, estudo de Baldissera e Bueno (2012) realizado com mulheres hipertensas, mostrou que essa população vivenciava as práticas de lazer como forma de enfrentamento e tratamento da hipertensão arterial sistêmica (HAS). O estudo não aprofunda de que forma se efetuava esse tratamento.

No âmbito da saúde mental, Rios et al. (2011), tecendo considerações voltadas à relação entre as atividades físicas de lazer e saúde, menciona que essas práticas atuam como mecanismos que podem diminuir ou prevenir quadros de ansiedade e outras alterações mentais (transitórias ou permanentes). Desse modo, o lazer atua como mecanismo de compensação e/ou prevenção do estresse decorrente do estilo de vida moderno. Nas palavras dos autores: as atividades físicas de lazer agem "como aliviadores das tensões, renovando as energias e proporcionando prazer, relaxamento e bem-estar aos seus praticantes" (Rios et al., 2011, p. 99).

Achados de Rios et al. (2011) corroboram com outras publicações nas quais foram encontrados índices elevados de transtornos psiquiátricos 
em adolescentes e jovens que não participam ou que vivenciam insuficientemente atividades físicas de lazer.

Com enfoque na saúde mental em geral, Baldissera e Bueno (2012), baseados em diversos autores, afirmam que o lazer funciona como amortecedor do estresse. Trata-se de uma forma de diminuir os efeitos deletérios de eventos desagradáveis do cotidiano. Os autores, ao considerarem que vivências de lazer têm relação com o prazer, e que o prazer constitui fator fundamental para o bem estar, pontuam que essa prática colabora para a saúde, sobretudo, para a saúde mental.

Tendo em vista a abrangência e a complexidade do fenômeno "lazer", qualquer análise individual sobre as distintas abordagens apresenta características reducionistas. Ademais, estudos (Werneck, Gomes e Melo, apud Pinheiro; Gomes, 2011) mostram que é crescente o número de áreas de conhecimento que se dedicam aos estudos sobre o lazer.

A contribuição de Tabares (2006), ao afirmar que o esporte e o lazer vêm sendo considerados como um dos principais "mediadores do desenvolvimento humano", é uma indicação de que se trata de um fenômeno que envolve os sujeitos em suas diversas nuances, sobretudo, aquelas voltadas ao aspecto social, tais como emancipação humana e cidadania. Considerando a gama de variáveis que a reflexão sobre essa temática requer, entende-se que se faz necessário estabelecer uma relação de complementaridade entre as distintas abordagens.

\section{Reflexões teórico-práticas sobre políticas públicas de esporte e lazer no Brasil}

Ao longo da década de 1990, no campo das políticas sociais no Brasil, várias leis infraconstitucionais procuraram consolidar o esporte e o lazer como direito. Entre elas, se destacam: O estatuto da criança e adolescente (no 8.069/1990), Política Nacional para Integração das pessoas Portadoras de Deficiência (decreto-lei no 3.298), Lei de Diretrizes e Bases da Educação (no 9.394/1996). Porém, no cenário das medidas neoliberais adotadas pelo Estado, foram poucos os avanços na garantia do direito ao 
lazer, tendo uma distância significativa entre a normatização e as políticas sociais desenvolvidas. (Ewerton; Matias, 2017, p. 59)

Diz a Carta Magna que o direito social ao lazer é responsabilidade do Município. Dentro de sua função social, como entidade titular de competências próprias, esse ente da federação deve promover políticas públicas educacionais utilizando o lazer como objeto e como instrumento de educação, ou seja, vinculado à educação para e pelo lazer. No Capítulo II, art. $6^{\circ}$ da CF, vislumbra-se como direitos sociais a educação, a saúde, o trabalho, a moradia, o lazer, a segurança, a previdência social, a proteção à maternidade e à infância, a assistência aos desamparados.

Há que lembrar-se, portanto, que uma coisa é considerar o lazer e o esporte como direito, do ponto de vista legislativo; outra coisa é gerir políticas públicas que contemplem ações ativas e efetivas para o atendimento das demandas. Para Pinto (2008), essas demandas estão no nível das necessidades básicas. Segundo o autor, o paradigma dominante no campo das políticas sociais (no qual o lazer se inclui) deve considerar os direitos sociais, ou seja, o atendimento das necessidades básicas de todos os cidadãos, com sustentação nos princípios da inclusão e equidade. Além de ser um direito social, alguns autores (a exemplo de Bruhns, 1997; Pinto, 2008) defendem a visão de que o lazer é uma necessidade humana, embora não exista consenso na literatura sobre essa questão.

No âmbito de Política de Estado, a partir de 2003, no Governo Lula, observaram-se movimentos efetivos de elaboração e implementação de políticas públicas de esporte e lazer no Brasil. Foi criado o Ministério do Esporte (ME), cuja missão era "formular e implementar políticas públicas inclusivas e de afirmação do esporte e do lazer como direitos sociais dos cidadãos, colaborando para o desenvolvimento nacional e humano" (Brasil, 2004).

A estrutura administrativa desse ministério envolveu originalmente quatro secretarias, sendo uma Secretaria Executiva e três Secretarias Nacionais de Esporte: Secretaria Nacional de Esporte Educacional (SNEED), Secretaria Nacional de Desenvolvimento do Esporte e de Lazer (SNDEL) e Secretaria Nacional de Esporte de Alto Rendimento (SNEAR). A par- 
tir de 2011, uma reestruturação no Ministério unificou as duas secretarias (SNEED e SNDEL) e foi instituída a SNELIS, Secretaria Nacional de Esporte, Lazer e Inclusão Social.

Com a criação do $\mathrm{ME}$, se vislumbra uma nova concepção de gestão pública para o esporte e o lazer; e se veem as chances de atendimento à $\mathrm{CF}$, no que diz respeito à atenção ao lazer como um direito social de todo cidadão brasileiro. Entretanto, a criação desse ministério não significou a garantia do atendimento ao direito constitucional ao lazer. Starepravo (2011), baseado em distintos autores, assinala a existência de diversas barreiras que impedem o desenvolvimento de políticas efetivas para o setor no Brasil. Entre essas barreiras, o autor destaca o olhar prioritário ao esporte de alto rendimento, o assistencialismo e utilitarismo atribuído ao esporte e ao lazer; e, finalmente, a hierarquização de prioridades sociais, que deixa o esporte e o lazer como últimas demandas a serem atendidas.

Como parte da agenda política desenvolvida na área, o Governo Federal, através do ME, promoveu três Conferências Nacionais, a fim de orientar e subsidiar a Política Nacional do Esporte e do Lazer no Brasil. As três edições da Conferência (2004, 2006 e 2010) possibilitaram a ampliação da presença da sociedade na definição da política setorial.

A I Conferência Nacional, com o tema "Esporte, Lazer e Desenvolvimento Humano", entre outros pontos resultou na proposta de criação do Sistema Nacional do Esporte e Lazer, descentralizado e regionalizado, com eixos em políticas nacionais de gestão participativa e controle social (Brasil, 2004). Destacam-se nessa primeira edição os rumos para a construção da Política Nacional do Esporte, aprovada pelo Conselho Nacional do Esporte em 2005, que reafirma a perspectiva de lazer como direito.

[...] o acesso ao esporte e lazer é direito de cada um e dever do Estado, pelo qual deve se garantir e multiplicar a oferta de atividades esportivas, competitivas e de lazer a toda a população, combatendo todas as formas de discriminação e criando igualdade de oportunidade, prioritariamente, à população carente e aos marginalizados, como negros, índios, deficientes e mulheres das camadas mais pobres (Brasil, 2005, p. 36). 
Na II Conferência Nacional do Esporte, foram debatidos os eixos para estruturação de um Sistema de Esporte e Lazer: estrutura, organização, agentes e competências; recursos humanos e formação; gestão e controle social; e financiamento. Essa edição foi marcada pelo lançamento da Lei de Incentivo ao Esporte, um marco no financiamento do esporte no Brasil. (Ewerton; Matias, 2017, p. 64).

Na III Conferência, realizada em 2010, tendo como pano de fundo a conquista para realizar no país os principais megaeventos esportivos, a temática central foi a projeção do país entre os 10 mais importantes no âmbito internacional; ainda assim, o lazer foi debatido entre os participantes, delineando metas dos programas e ações para os anos seguintes (Ewerton; Matias, 2017, p. 64).

Considerando o que foi dito anteriormente, Araújo (2013, p. 6) aponta para a necessidade de avaliar "[...] se as Conferências foram, de fato, definidoras da agenda política desenvolvida na área, e se as suas deliberações tiveram influência na definição de políticas para universalizar o direito ao esporte".

Também se faz necessário saber que ações foram realizadas e até que ponto as metas definidas foram alcançadas.

Num estudo que propôs avaliar se as deliberações das Conferências Nacionais de Esporte ampliaram efetivamente a participação popular na política esportiva do Governo Lula, no período de 2003 a 2010, Araújo (2013) constatou que a maioria das decisões tomadas sobre o eixo gestão e controle social não foi implementada. A autora identificou a priorização aos megaeventos em detrimento da consolidação do Sistema Nacional de Esporte e Lazer, para garantir a universalização do direito ao esporte, conforme indicado nas conferências.

No âmbito do esporte e do lazer, no período de 2003 a 2010, o Governo Federal realizou um programa com amplitude nacional, denominado Programa Esporte e Lazer da Cidade (PELC). Essa ação visa:

[...] suprir a carência de políticas públicas e sociais que atendam às crescentes necessidades e demandas da população por esporte recrea- 
tivo e lazer, sobretudo daquelas em situações de vulnerabilidade social e econômica, que reforçam as condições de injustiça e exclusão social a que estão submetidas (Brasil, apud Souza, 2010, p. 17).

São objetivos centrais do PELC: "ampliar, democratizar e universalizar o acesso à prática e ao conhecimento do esporte recreativo e de lazer, integrando suas ações às demais políticas públicas, favorecendo o desenvolvimento humano e a inclusão social" (Brasil apud Souza, 2010, p. 17).

Para atender a esses objetivos, o PELC está organizado de modo a atender três eixos centrais. Para Souza (2010) e Starepravo (2011), esses eixos podem ser assim resumidos:

1. Funcionamento de núcleos de esporte recreativo e de lazer. Os núcleos estão instalados em diversas regiões do Brasil e têm como objetivo garantir o direito ao acesso de qualidade a políticas públicas de lazer e de esporte, em sua dimensão recreativa;

2. Funcionamento da Rede CEDES. A Rede, vinculada à Secretaria Nacional de Desenvolvimento do Esporte e do Lazer (SNDEL) do Ministério do Esporte, apoia Centros de Pesquisas voltados ao desenvolvimento de Esporte Recreativo e de Lazer nas Instituições de Ensino Superior. Ao longo de sua história apoiou pesquisas que não eram contempladas com os financiamentos até então realizados pelo Ministério do Esporte. Mais adiante, em 2015, o programa Rede CEDES ampliou as ações com o financiamento/ apoio à criação de Centros de Pesquisas voltados a Políticas Públicas de esporte e lazer em todos os Estados da Federação. A Rede tem como objetivos estimular e fomentar a produção e difusão de conhecimentos científico-tecnológicos, voltados para a qualificação das políticas públicas de esporte recreativo e do lazer.

3. Implantação e modernização de infraestrutura para esporte recreativo e lazer. Essa ação é realizada pela Secretaria Executiva do Ministério do Esporte e prevê a construção e a reforma de equipamentos para o setor. 
De acordo com Souza (2010, p. 18),

Em termos da abrangência geográfica, o PELC tem em vista atingir todos os Estados da Federação e o Distrito Federal, por meio de atividades desenvolvidas no âmbito municipal e sob a égide estadual, com a participação também de ONGs.

Destaca ainda a autora que, para 2010, a meta era beneficiar em torno de 655.100 pessoas, já que nesse ano foram aprovados 63 novos convênios. A seleção dos parceiros para a definição dos convênios de funcionamento dos núcleos do PELC, desde 2007, se dá por meio de Chamada Pública (Ewerton; Araújo apud Souza, 2010).

Ainda orientada por Ewerton e Araújo, Souza (2010) explicita em que base se sustenta o PELC:

[...] o Programa orienta-se pelos princípios norteadores da Política Nacional de Esporte e lazer da reversão do quadro atual de injustiças, exclusão e vulnerabilidade social; do esporte e do lazer como direito de cada um e dever do Estado; da universalização e inclusão social e da democratização da gestão e da participação (p. 8).

Dentre as dificuldades enfrentadas pelo ME para construir políticas públicas que garantissem o direito ao lazer a todos os cidadãos, encontra-se a laboriosa tarefa de adotar um conceito de lazer (Souza, 2010). Conforme já mencionado em outro ponto, o esporte e o lazer assumem diversas manifestações, amparadas por distintas abordagens teóricas.

A ação educativa foi o "carro-chefe" da formulação e implementação de políticas públicas de esporte e lazer no Brasil na última década. As ações teórico-práticas do ME caminharam para a integração e participação comunitária, a elevação da autoestima dos participantes e a inclusão social. Tudo isso a fim de atuar na reversão do quadro atual de injustiças, exclusão e vulnerabilidade social.

Entretanto, no ano de 2019, com a posse do novo Governo nas esferas federal e estadual, o esporte e o lazer perderam espaço do ponto de 
vista estrutural. Em nível federal, foi extinto o Ministério do Esporte, e alguns governadores seguiram o mesmo exemplo com relação às Secretarias de Esportes e Lazer. Paraná, Minas Gerais, Santa Catarina, Sergipe e Pernambuco são exemplos de Estados que extinguiram suas secretarias nesse setor. Além deles, Goiás, Mato Grosso do Sul, Tocantins, Bahia e Acre mantiveram na sua estrutura administrativa o esporte, mas sem uma secretaria exclusiva.

Os Ministérios do Esporte e da Cultura (também extinto) foram incorporados como secretarias do Ministério da Cidadania e Ação Social. Já os Estados adotaram práticas específicas nesse processo, sendo a inserção das Secretarias de Esporte e Lazer e/ou Turismo nas Secretarias de Educação a prática predominante.

Sabe-se que somente o espaço ocupado na estrutura hierárquica não define a qualidade do trabalho a ser realizado, entretanto, diminui a importância dentro do governo, o que pode acarretar numa redução das políticas para o setor. Enfim, essas mudanças podem sinalizar que o esporte e o lazer deixam de ser considerados vetores de organização no atual projeto de desenvolvimento do Governo Federal e de alguns Estados da Federação, indicando, além de retrocesso político, drástica redução orçamentária. O tempo dirá até que ponto as demandas da área serão atendidas pelo próximo Governo Federal.

\section{Considerações finais}

Tendo em vista os objetivos pretendidos neste estudo e as reflexões apresentadas, deduz-se que:

- As principais contribuições para a composição dos conceitos atuais de lazer no Brasil iniciam-se com trabalhos de Dumazedier, cuja referência permanece em publicações atuais. Tais preceitos foram seguidos por Marcellino, Brunhs, Oliveira, Gomes, Werneck, Pinheiro e Lacerda, que também contribuíram para a concepção atual de lazer. 
- As diferentes abordagens de lazer tratadas isoladamente não dão conta de conceituar e caracterizar esse fenômeno que possui uma multiplicidade de sentidos.

- As políticas públicas de esporte e lazer no Brasil, até meados de 2017, acompanham o que foi planejado a partir de 2003, com o Governo Lula. Nestas, o esporte e o lazer foram concebidos como instrumento educacional, com objetivo de diminuir a vulnerabilidade e a exclusão sociais.

A prioridade da agenda governamental, desde 2003, foi o financiamento da infraestrutura esportiva e de lazer e os grandes eventos esportivos. Contudo, mesmo deixando em terceiro plano os programas sociais, é importante reconhecer que o Ministério do Esporte atuou em todos os eixos estruturantes, e em todas as dimensões do esporte. Assim, os programas, ações e normatizações do período serviram para qualificar a oferta do esporte e do lazer, com produção de material pedagógico, fomento e difusão do conhecimento de Política Pública de Esporte e Lazer, documentação e informação, acompanhamento, monitoramento e avaliação de Políticas Públicas, parcerias intersetoriais.

Os programas tiveram aderência de entes municipais, estaduais e federais, que se caracterizam pela participação da sociedade civil no controle das ações, pela gestão descentralizada e pela auto-organização das comunidades no desenvolvimento do esporte e lazer.

Concluímos este texto reafirmando que muito foi produzido a partir da década de 1980, para aprofundar teoricamente conceitos e abordagens sobre Lazer, bem como as normatizações que colocam o esporte e o lazer como direitos sociais e dever do Estado. Apesar dos progressos constatados nos últimos anos para garantir o esporte e o lazer como direito, diante do quadro de desigualdade de acesso aos bens culturais da humanidade do campo do lazer existentes no Brasil, ainda tem muito a ser feito. Houve avanço no desenvolvimento dos programas e projetos, na qualificação dos profissionais, na participação da sociedade civil, e outras ações. Contudo, há que avançar na definição das fontes de financiamento, na implementação 
de políticas intersetoriais, no acompanhamento e avaliação dos programas, na participação e controle social. Esses são alguns dos desafios colocados para aqueles que atuam no campo do lazer, em especial para o Governo Federal que iniciou seu mandato em 2019.

\section{Referências}

ALVES, C; ISAYAMA, H, F. Considerações sobre o lazer na idade adulta. In: MARCELLINO, N, C. Repertório de atividades por fases da vida. Campinas: Papirus, 2006.

AQUINO, C.A.B.; MARTINS, J.C.O. Ócio, lazer e tempo livre na sociedade do consumo e do trabalho. Rev. Mal-Estar Subj. v.7, n.2, Fortaleza, set. 2007. Disponível em: <http:// pepsic.bvsalud.org/scielo.php?script=sci_arttext\&pid $=S 151861482007000200013>$. Acesso em: 15 ago. 2018.

ARAÚJO, S.M. Conferências nacionais de esporte: o debate sobre controle social.JORNADA NACIONAL DE POLÍTICAS PÚBLICAS, 4. Universidade Federal do Maranhão. 2013. Disponível em: <http://www.joinpp.ufma.br/jornadas/joinpp2013/JornadaEixo2013/ anaiseixo8direitosepoliticaspublicas/conferenciasnacionaisdeesporteodebatesobrecontrolesocial.pdf $>$. Acesso em: 20 fev 2018.

BACHELADENSK, M.S.; MATIELLO JÚNIOR, E. Contribuições do campo crítico do lazer para a promoção da saúde. Revista Ciência e Saúde coletiva, v.15, n.5, 2010. Disponível em: < https://www.scielosp.org/article/csc/2010.v15n5/2569-2579/>. Acesso em: 25 ago 2018 .

BALDISSERA, V.D.A.; BUENO, S.M.V. O lazer e a saúde mental das pessoas hipertensas: convergência na educação para a saúde. Rev. esc. Enferm, São Paulo, v.46, n.2, abr. 2012. Disponível em: <http://www.scielo.br/scielo.php?script=sci_arttext\&pi$\mathrm{d}=$ S008062342012000200016>. Acesso em: 17 ago. 2018.

BRASIL. Conferência Nacional do Esporte, 1. Ministério do Esporte. Documento Final. Brasília, 2004. Disponível em: <http://www.ipea.gov.br/participacao/images/pdfs/conferencias/Esporte/deliberacoes_1_conferencia_esporte.pdf >. Acesso em: 2 jun. 2017.

BRASIL. CONFERÊNCIA NACIONAL DO ESPORTE, 2. Ministério do Esporte. Brasília, 2005. Disponível em: < www2.esporte.gov.br/conferencianacional/.../textoVPoliticaNacionalEsporte180106.d...>. Acesso em 2 jun. 2017.

BRUHNS, H.T. Relações entre Educação Física e o lazer. In: BRUHNS, H.T. (Org.). Introdução aos estudos do lazer. Campinas: Edunicamp, 1997.

CASTELLANI FILHO, L. 0 Gestão Pública e política de lazer: a formação de agentes sociais. Campinas, SP: Autores Associados, 2007. 
CUENCA CABEZA, M. O ócio autotélico. Revista do Centro de pesquisa e formação, maio, 2016. Disponível em: <https://www.sescsp.org.br/files/artigo/f0424b9b-7e21-4e59-a24f-9dd945f7c200.pdf >. Acesso em: 1 jum. 2018.

DUMAZEDIER, J. A revolução cultural do tempo livre. São Paulo: Estúdio Nobel. SESC, 1994.

DUMAZEDIER, J. Lazer e cultura popular. 3 ed. São Paulo: Perspectiva, 2001.

EWERTON, A.N.; MATIAS, W. B. Gestão Estratégica das Experiências de Lazer na Esfera Federal. In: AZEVEDO, P.H.; BRAMANTE, A.C. (Orgs.). Gestão estratégica das experiências de lazer. A.C. Curitiba: Appris, 2017.

GOMES, C . L. Lazer-Concepções. In: GOMES, C.L. (Org.). Dicionário crítico do lazer. Belo Horizonte: Autêntica, 2004a.

GOMES, C . L.. Lazer “dimensão da cultura constituída”. Verbetes Lazer. Concepções. In: GOMES, C . L. (Org.). Dicionário crítico do lazer. Belo Horizonte: Autêntica, 2004b.

GOMES, C . L.. Lazer, trabalho, educação: relações históricas, questões contemporâneas. 2. ed. Belo Horizonte: Editora UFMG, 2008a.

GOMES, C . L. Lazer e descanso. In: SEMINÁRIO LAZER EM DEBATE. São Paulo, Anais... São Paulo: USP, 2008. Disponível em: <http://www.uspleste.usp.br/eventos/lazer-debate/anais-christianne.pdf.pdf $>$. Acesso em: 7 dez. 2008b.

GOMES, C.; PINHEIRO, M.; LACERDA, L. Lazer, turismo e inclusão social: intervenção com idosos. Belo Horizonte: UFMG, 2010.

IWANOWICZ, J.B. Aspectos psicológicos do lazer. In: Bruhns, H.T.(Org.) Introdução aos estudos do Lazer. Campinas: Edunicamp, 1997.

MARCELLINO, N. C. Lazer e educação. Campinas, SP: Papirus, 1987.

MARCELLINO, N. C. Pedagogia da animação. 8.ed. Campinas, SP: Papirus, 1990.

MARCELLINO, N. C. Lazer e educação. Campinas, SP: Papirus, 1995.

MARCELLINO, N. C. O conceito de lazer nas concepções da Educação Física Escolar: o dito e o não dito. Congresso de Educação Física e Ciências do Desporto dos Países de Língua Portuguesa, 8, 2000. Disponível em: < https://ufsj.edu.br/portal-repositorio/ File/dcefs/Prof._Adalberto_Santos2/13o_conceito_de_lazer_nas_concepcoes_da_ef_escolar-o_dito_e_o_nao_dito10.pdf >. Acesso em: 6 ago. 2018.

MARCELLINO, N. C. A teoria sociológica da decisão e a ação comunitária como estratégia de planejamento em ação. In: PINTO. L.M.S.M. (Org.). Como fazer projetos de lazer: Elaboração, execução e avaliação. (Campinas: Papirus, 2007. 
MARCELLINO, N. C. Políticas de lazer: Mercadores ou educadores? Os cínicos bobos da corte. In: MARCELLINO, N.C. (Org.). Políticas públicas de lazer. Campinas: Alínea, 2008.

NUNES, M.F.O.; HUTZ, C.S. Análise da Produção de Artigos Científicos sobre o lazer: Uma Revisão. Psicologia: Teoria e Pesquisa, v. 30, n.3, jul./set. 2014. Disponível em: <http://www.scielo.br/pdf/ptp/v30n3/08.pdf >. Acesso em: 9 ago. 2018.

OLIVEIRA, P.S. O lúdico na vida cotidiana. In: Introdução aos estudos do lazer. (Org.). BRUHNS, H.T. Campinas: Edunicamp, 1997.

OLIVEIRA, J.J.; FREITAS, R.F. Consumo. In: GOMES, C.L. (Org.). Dicionário crítico do lazer. Belo Horizonte: Autêntica. 2004.

PINHEIRO, M.F.G.; GOMES, C.L. A temática do lazer em cursos de graduação da área da saúde. Motriz: Rev. educ. fis, Rio Claro, v.17 n.4, out./dez. 2011. Disponível em: < http:// www.scielo.br/scielo.php?script=sci_arttext\&pid=S1980-65742011000400002>. Acesso em: 29 nov. 2017.

PINTO, L.M. S. Formação de educadores e educadoras para o lazer; saberes e competências. Revista Brasileira de Ciências do Esporte, Campinas, v.22, n.3. maio 2001. Disponível em: < http://revista.cbce.org.br/index.php/RBCE/article/view/383>. Acesso em: 21 jan. 2018.

PINTO, L. M. S. Estado e sociedade na construção de inovações nas políticas sociais de lazer no Brasil. In: MARCELLINO, N. C.(Org.). Políticas Públicas de Lazer. Campinas: Alínea, 2008.

RAMOS, R.; ISAYAMA, H. Lazer e esporte: olhar dos professores de disciplinas esportivas do curso de Educação Física. Rev. bras. Educ. Fís. Esporte. São Paulo, v.23, n.4, p.3. out./ dez.2009. < http://www.scielo.br/pdf/rbefe/v23n4/v23n4a07.pdf >. Acesso em: 25 fev 2017.

RIOS, L.C. et al. Atividades físicas de lazer e transtornos mentais comuns em jovens de Feira de Santana, Bahia. Rev Psiquiatr. Rio Gd Sul, v. 33, n.2. Disponível em: < http://www. scielo.br/pdf/rprs/v33n2/v33n2a06.pdf>. Acesso em: 17 ago. 2018.

SAMPAIO, T.M.V.; SILVA, J.V.P. (Org.) Lazer e cidadania: horizontes de uma construção coletiva. Brasília: Universa, 2011.

SILVA, C.L. et al. Atividade física de lazer e saúde: uma revisão sistemática. Mudanças. Psicologia da Saúde, v.25, n.1, jna./jun. 2017. Disponível em: < https://www.metodista.br/revistas/revistasims/index.php/MUD/article/viewFile/7185/5791>. Acesso em: 17 ago. 2018.

SILVA, M.S.; ISAYAMA, H.F. Lazer e educação no programa Escola Integrada. Educação em Revista. Belo Horizonte, n. 33, 2017. Disponível em: < http://www.scielo.br/pdf/edur/ v33/1982-6621-edur-33-e156123.pdf>. Acesso em: 9 ago. 2018. 
SOUZA, E.S. Sistema de monitoramento e avaliação dos Programas Esporte e Lazer da Cidade e Segundo Tempo do Ministério. Gráfica e editora O Lutador, 2010. Disponível em <http://portal.esporte.gov.br/arquivos/snee/segundoTempo/sistemaMonitoramentoAvaliacaoProgramasEsporte.pdf>. Acesso em: 30 ago. 2018.

STAREPRAVO, F.A. Políticas públicas de esporte e lazer no Brasil: aproximações, intersecções, rupturas e distanciamentos entre os subcampos político/burocrático e científico/acadêmico. Tese (Doutorado em Educação Física)- Departamento de Educação Física, Setor de Ciências Biológicas da Universidade Federal do Paraná. Curitiba, 2011. Disponível em: < http://www.pgedf.ufpr.br/downloads/TESES/2011/Tese\%20Fernando\%20Augusto\%20Starepravo.pdf>. Acesso em: 28 ago. 2018.

STIGGER, M.P. Lazer, cultura e educação: possíveis articulações. Rev. Bras. Cienc. Esporte, Campinas, v.30, n.2, jan. 2009. Disponível em: < file://C:/Users/IVETE/Downloads/437-1289-1-PB.pdf>. Acesso em: 9 ago. 2018.

TABARES, J. F. O esporte e a recreação como dispositivos para a atenção da população em situação de vulnerabilidade social. In: MELLO, V. de A.; TAVARES, C. (Orgs.). O exercício reflexivo do movimento: educação física, lazer, e inclusão social. Rio de Janeiro: Shape, 2006.

TASCHNER, G.B. Lazer, cultura e consumo. Administração Mercadológica. REA. Revista de Administração de Empresas, São Paulo, v.40, n.4, out/dez. 2000. Disponível em: <http://www.scielo.br/pdf/rae/v40n4/v40n4a04.pdf>. Acesso em: 15 ago. 2018.

WERNECK, C.L.G. Significados de recreação e lazer no Brasil: reflexões a partir da análise de experiências institucionais (1926-1964). 2003.. Tese (Doutorado em Educação) Universidade Federal de Minas Gerais, Belo Horizonte, 2003. Disponível em: <http://www. bibliotecadigital.ufmg.br/dspace/handle/1843/HJPB-5NVJWV>. Acesso em: 1 set. 2017.

WERNECK, C.L.G.; ISAYAMA, H.F. Lazer, Cultura, indústria cultural e consumo. In: WERNECK, C.L.G; STOPPA, E.A; ISAYAMA, H.F. (Orgs.).Lazer e Mercado. Campinas: Papirus, 2001. 


\title{
2. A HISTÓRIA ORAL NA MODALIDADE TRAJETÓRIA DE VIDA COMO PROPOSTA DE PRODUÇÂOO DO CONHECIMENTO EM PESQUISA SOBRE LAZER
}

\author{
Ivete de Aquino Freire \\ Ramón Núñez Cárdenas \\ Lilian Maria Moser \\ Iná de Aquino Freire \\ Idê Freire Seixas \\ Stefhany Soares Maia
}

\section{Introdução}

Este capítulo relata os procedimentos metodológicos utilizados numa pesquisa sobre lazer de idosas nascidas no município de Porto Velho, no Estado de Rondônia, ou que vieram para essa localidade ainda na infância. O estudo investigou as práticas de esporte e lazer das mulheres associadas ao grupo de convivência "Pioneiras de Rondônia”. Essas mulheres também fazem parte do grupo de Trabalho Social com Idosos (TSI), do SESC de Rondônia.

O grupo "Pioneiras de Rondônia (APERON)" foi criado oficialmente em 2014. É uma associação sem fins lucrativos, de caráter social, cultural e educativo. Entre seus objetivos estão promover a realização de ações e eventos; promover e participar de oficinas, festivais, mostras, cursos, encontros, viagens, debates, montagens, apresentações em âmbitos públicos, privados, particular ou não; defender e utilizar todas as legislações de incentivo a cultura, nacional, estadual e municipal; e promover, executar projetos, palestras, simpósios, seminários de cunho histórico e patrimonial (APERON, 2014). O grupo iniciou com 36 pessoas e, no ano de 2019 contava com 120 sócios cadastrados.

Para a composição do estudo, os pesquisadores inicialmente chegaram até essas mulheres por meio de contatos informais com algumas delas 
durante viagens de lazer organizadas pelo grupo "Pioneiras de Rondônia". Nessas ocasiões, determinados pesquisadores tiveram a oportunidade de conhecer aspectos das histórias de vida dessa população. Nos longos relatos informais, predominavam as diferentes dificuldades enfrentadas por elas; marcadas pela presença do trabalho, iniciado na infância, estendendo-se até a fase adulta.

Para a participação na pesquisa, essas mulheres foram convidadas por abordagens antes ou após reuniões do grupo de convivência. Determinou-se levantar informações tanto sobre a fase atual das suas vidas quanto de etapas anteriores. Desse modo, buscou-se identificar e caracterizar as manifestações de lazer vivenciadas pelas idosas na época em que eram crianças/ meninice, durante a pré-adolescência/adolescência, na maturidade e na fase atual de suas vidas.

\section{A história de vida no contexto do lazer}

Ao buscar uma metodologia de trabalho investigativo que "desse conta" de atender aos objetivos da pesquisa, entendeu-se de imediato que se fazia necessário um método que alcançasse delinear a trajetória vivida por essas mulheres. Logo de início, pensou-se em optar pela História Oral (HO). Com o avançar das leituras sobre a questão, o que era uma ideia primitiva foi se consolidando, chegando-se ao ponto de constatar-se que essa seria a metodologia de trabalho ideal para o que se propunha.

Segundo Vieira (2006, p. 1),

A história oral é um termo amplo que recobre tipos variados de relatos a respeito de fatos não registrados por documentação escrita ou cuja documentação se quer completar numa outra perspectiva. Colhida por entrevistas realizadas de maneiras diferenciadas, a história oral registra a experiência de um indivíduo ou de vários indivíduos de uma mesma coletividade. 
Gonçalves e Lisboa (2007, p. 2), a partir de Alberti, também contribuem na opção por esse método, ao esclarecer que a $\mathrm{HO}$ é:

[...] um método de pesquisa (histórica, antropológica, sociológica, etc.) que privilegia a realização de entrevistas com pessoas que participam de, ou testemunharam acontecimentos, conjunturas, visões de mundo como forma de se aproximar do objeto de estudo [...]. Estuda acontecimentos históricos, instituições, grupos sociais, categorias profissionais, movimentos, etc., à luz de depoimentos de pessoas que deles participaram ou os testemunharam.

Justifica-se o uso da $\mathrm{HO}$ na investigação sobre o lazer na trajetória de vida das idosas pelas características desse método, conforme mencionam Camargo (1994) e Vieira (2006). Outra justificativa para o uso da HO está no dizer de Ricoeur (apud Sartori, 2013) quando afirma que essa metodologia empenha-se em agregar múltiplas temporalidades. O lazer na trajetória de vida das idosas, na pesquisa realizada, implicou o resgate da sua trajetória histórica, buscando compreender algumas relações que se estabeleceram ao longo de sua existência. A HO surgiu também como uma alternativa importante de valorização das memórias dessas mulheres, como diz Pollak (1989), das memórias que permanecem à margem da história oficial (Sartori, 2013).

Optou-se pela modalidade Trajetória de Vida, de acordo com a classificação de Gonçalves e Lisboa (2007), que entendem trajetória de vida como o ciclo da vida ou etapas da vida. Seguindo a visão de Luís Arango (apud Gonçalves e Lisboa; 2007), esse termo tem profunda relação com trajetória social, uma vez que, em cada momento da existência, os indivíduos ocupam simultaneamente várias posições.

A partir do que diz Bourdieu, as autoras anteriormente mencionadas entendem trajetória como uma série de posições sucessivamente ocupadas por um mesmo agente (ou mesmo grupo), em um espaço, e submetidas a transformações estressantes.

Já na visão de Gonçalves e Lisboa (2007), a trajetória de vida pode ser considerada como parte de uma história de vida, com determinado 
percurso, itinerário ou ciclo, de modo a atender os interesses investigativos. Spindola e Santos (2005) compreendem a História de Vida como um método de pesquisa. Para as autoras, esse procedimento se mostra como uma alternativa que trabalha com a "estória" ou o relato de vida, ou seja, a história contada por quem a vivenciou. As autoras recorrem a Glat, para indicar que, nessa modalidade de pesquisa, o que interessa ao pesquisador é o ponto de vista do sujeito, expressado no relato. O "objetivo desse tipo de estudo é justamente apreender e compreender a vida conforme ela é relatada e interpretada pelo próprio ator" (Glat apud Spindola e Santos, p. 121, 2005).

Conforme o dito anteriormente, sabe-se que tanto o procedimento Trajetória de Vida quanto a modalidade História de Vida ressaltam, simultaneamente, a dinâmica do momento histórico vivido pelo sujeito. Relacionando esse aspecto com o objeto de estudo (esporte e lazer) recorre-se ao que afirma Marcellino (2000). Para esse autor, quando se trata de análise do fenômeno lazer, é fundamental situá-lo historicamente, contextualizando-o e considerando as circunstâncias que cercam o seu desenvolvimento. Para tanto, se faz necessária uma contextualização temporal, além de outros aspectos, tais como gênero, níveis e relação com outras áreas de atuação humana. Desse modo, utilizou-se no estudo a nomenclatura Trajetória de Vida, mesmo ciente de que esse termo se aproxima dos constructos da História de Vida. No estudo, buscou-se favorecer uma compreensão do contexto vivido pelas depoentes, acrescentando-se fatos históricos e socioculturais da época.

Com relação à população estudada e o método utilizado, alguns pontos precisam ser destacados. Resgatando a importância do contexto histórico nos estudos do lazer, Ecléa Bosi (Bosi, 1979) lembra que os velhos são os guardiões do passado. $\mathrm{O}$ relato das experiências dos mais velhos estimula uma retomada das "tradições e lembranças de um tempo longínquo e as insinuam como algo vivo nos meandros do presente". Reforça Sartori (2013): através da memória de idosos, podem-se perceber as transformações ocorridas no espaço, na história, no tempo, nos papéis sociais e no imaginário social ao longo das gerações. Com relação 
à temporalidade, a autora também pontua que o idoso abrevia o tempo de uma maneira complexa, não linear, conforme a incorporação da memória coletiva (oficial). As falas de Jurema e Aracy ilustram essa não linearidade no discurso das idosas.

Maior desgosto que eu tive foi de não aprender nada porque me botavam só pra trabalhar, né? Nunca me botaram numa escola, né? Logo lá no começo aonde eu morava não tinha nem, nem escola na época que eu não entendi lá, né? Quando eu vim pra Santarém foi pra casa dessa familia. Não me botaram pra é estudar, né? Só era pra fazer as coisas, limpá, varrê casa, lavá louça, fazê o que era preciso. Lavá. Essas coisas aí me ensinaram muito bem, mas... a leitura que é bom... eu fui aprender assinar o nome por aqui já. Até que eu assinava, mas agora com a vista, tô com a vista ruim, que eu não enxergo mais nada, nem adianta né? (Jurema).

A minha mãe casou também, casou a sua primeira vez. Ela foi casada duas vezes e meu pai quando morreu, ai ela chegou a ter 4 filho, né? Do primeiro. Os dois primeiros morreram. Ai quando meu pai morreu eu tava com um ano e quatro meses e minha mãe tava de resguardo do quarto filho, né? [...] que mataram. Aqui, então era um lugar muito pobre, né? Sofria muito. A gente sofria demais. A minha mãe teve três filhos que ela ficou viúva primeira vez. E aí casou eu sei que ao todo foram 13 filhos só se criou parece que 7 (Aracy).

A pesquisa procurou ponderar todas essas características no discurso das idosas, considerando as especificidades do método utilizado.

\section{Sobre a coleta de dados no contexto da História Oral}

A HO tem como técnica de coleta de dados a entrevista que atua como fio condutor da pesquisa. Nesse sentido, o estudo utilizou a técnica de entrevista com o recurso de gravação, mediante prévia aquiescência das depoentes, com a assinatura do TCLE.

A conversa iniciava-se com solicitação de que as depoentes falassem sobre suas memórias e experiências de lazer durante suas vidas. No decorrer da entrevista, e considerando os conteúdos abordados pelas mulheres, 
novos subtemas eram acrescentados, cumprindo o roteiro estabelecido para esse fim. O roteiro da entrevista acatou as distintas faixas etárias estudadas e diversos subtemas, conforme ilustra a Figura 1.

Figura 1 - Demonstrativo das palavras-chave constantes na entrevista
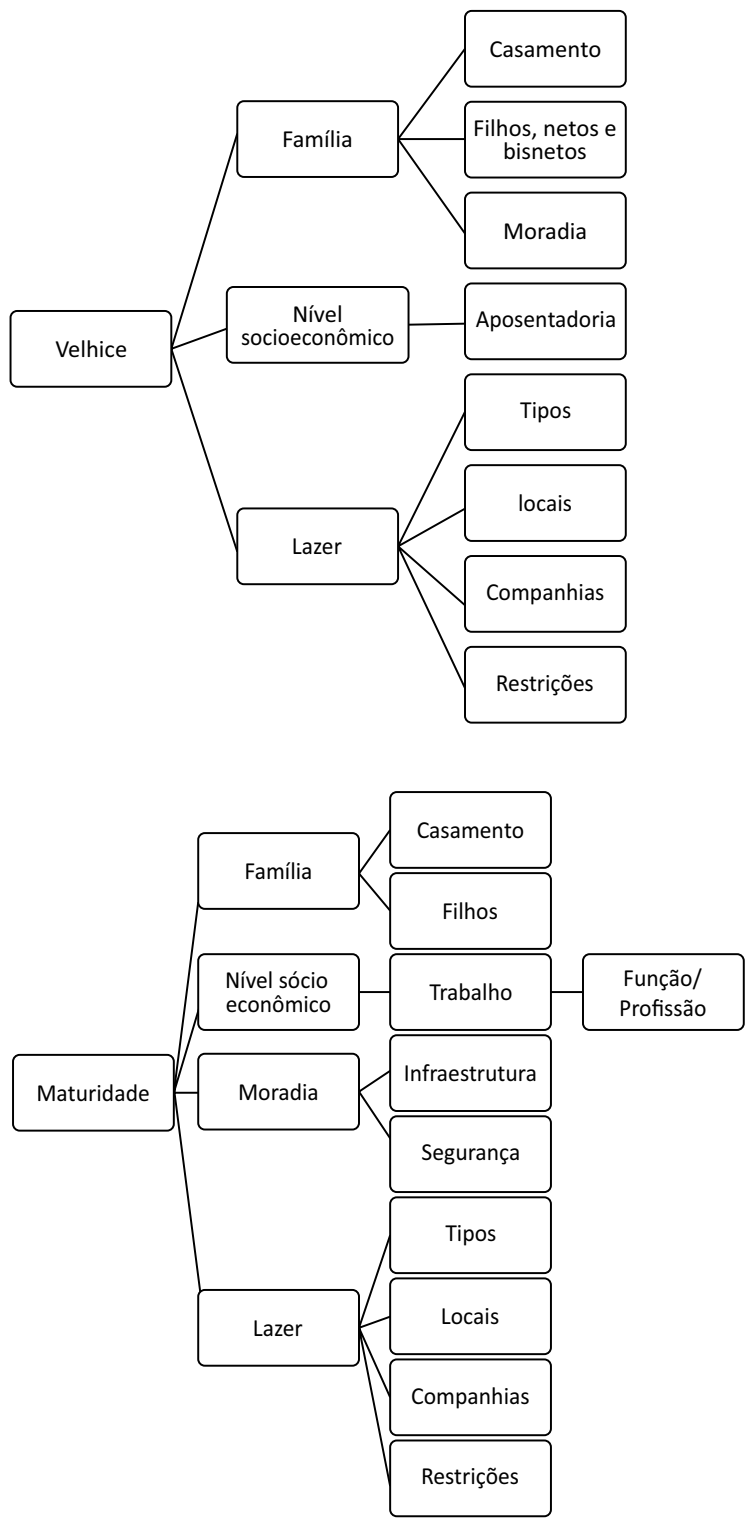

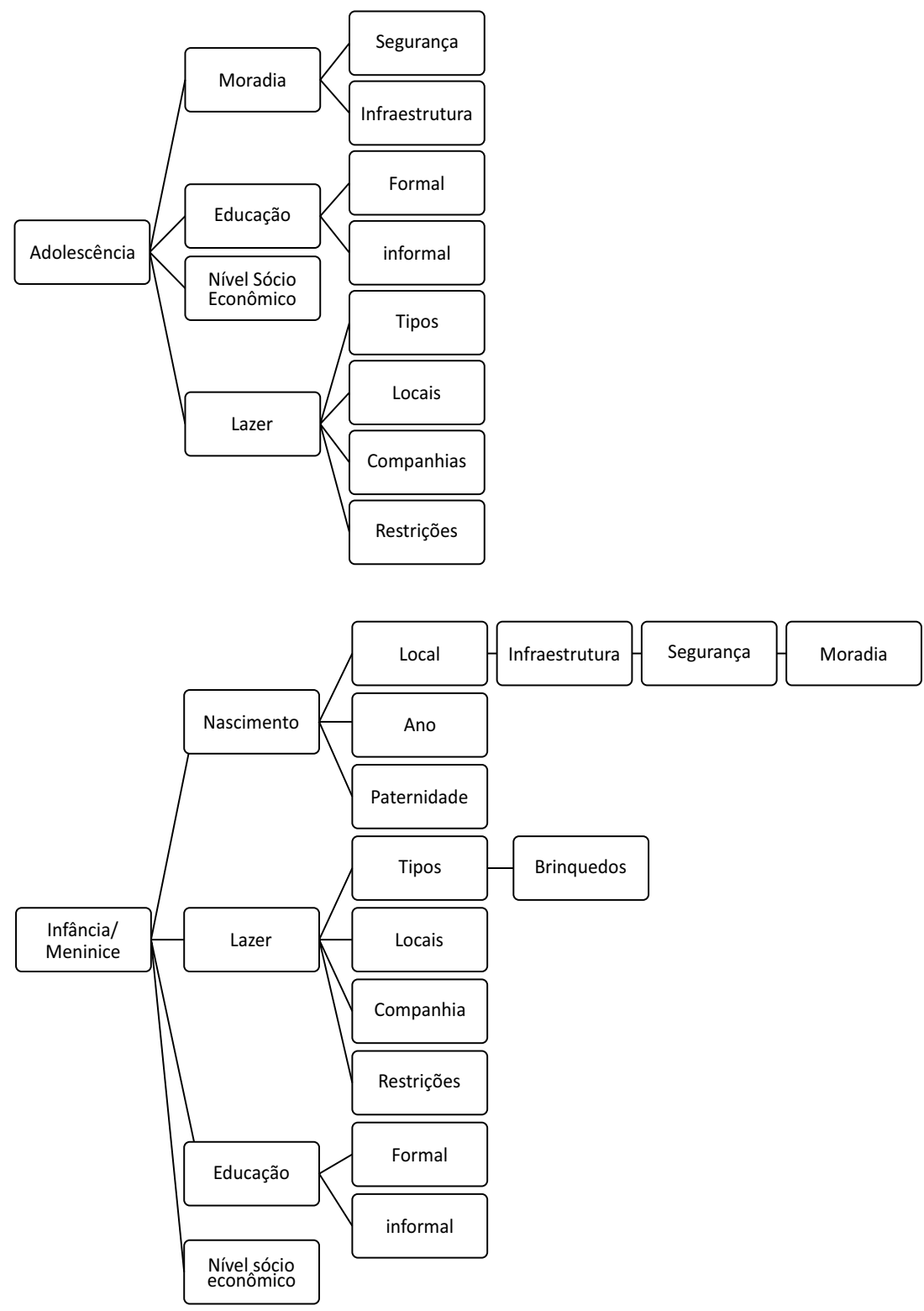

Observou-se que as mulheres começaram a expressar seus sentimentos de acordo com a memória do seu passado, na medida em que encontravam acolhida, confiança e, sobretudo, lealdade com as pesquisadoras. Estas se tornaram uma espécie de cúmplices do passado das depoentes, que foi se revelando pouco a pouco. Percebeu-se que ocorreu 
uma espécie de libertação de tudo que estava guardado em sua memória, como segredo absoluto, pois, durante sua trajetória de vida, não poderia contar para ninguém, por diversos motivos. $\mathrm{E}$ na $\mathrm{HO}$ elas encontraram espaço e confiança para dizer quem elas são de fato. Falar dos seus desejos e frustrações e também dos seus segredos e de suas “rebeldias”. Pois, segundo Portelli (apud Severino, 2016, p.240):

[...] não se pode desconsiderar a fecundidade da contribuição dos sentimentos subjetivos que se fazem presentes e marcantes na história oral, na oitiva dos sujeitos que vivenciaram os eventos, em que pese a efetividade das confusões, dos desvios imaginários, da imprecisão, da mistura dos desejos com a realidade, das falsificações, enfim, da condição [...].

Assim, na utilização da $\mathrm{HO}$ acontecem movimentos e dinamismos dos fatos muitas vezes já cristalizados e tornados oficiais e, por isso, muitas vezes, sem sentido.

$\mathrm{Na}$ transcrição dos relatos, foram preservadas as falas das depoentes, sem correção de qualquer tipo, visando garantir a fidedignidade daquilo que foi dito durante as entrevistas. Também se procurou registrar atitudes e comportamentos adotados durante a entrevista, dando ênfase a suspiros, choros, sorrisos e expressões diversas.

Quanto ao quantitativo de relatos colhidos, foi seguida a orientação de Spindola e Santos (2003). Utilizou-se o critério de saturação. A coleta dos depoimentos foi encerrada quando os dados atingiram o ponto de saturação, ou seja, começaram a se tornar repetitivos ou não acrescentaram fatos novos aos relatos anteriores. Também dessas mesmas autoras, seguiu-se a orientação de que o registro oral não se restringe a buscar informações, mas serve para dar voz a sujeitos invisíveis e, por meio da singularidade de seus depoimentos, para construir e preservar a memória coletiva.

Por meio da construção interativa de uma explicação, como não poderia deixar de ser, as memórias das idosas não se limitavam a descrever suas vivências de lazer; mas iam além, explorando riquezas de diversidades que levavam a equipe de pesquisadores a conhecer um tempo desconhecido. 
As lembranças e a expressão oral das diversas fases da vida exploravam simultaneamente as múltiplas temporalidades de morar na Amazônia, da antiga Porto Velho, da Estrada de Ferro Madeira Mamoré e das dificuldades de ser pobre e mulher.

\section{Sobre a população estudada}

Participaram do estudo nove mulheres nascidas entre 1928 e 1937. Quando elas nasceram, a localidade que hoje é Porto Velho, capital do Estado de Rondônia, possuía outra denominação e outro vínculo geopolítico. Recebia o nome de Santo Antônio, e era município do Estado do Amazonas, permanecendo nessa condição até 1940. A partir dessa data, o lugar é instituído como um município do Território Federal do Guaporé; e somente em 1956 se torna município do Território Federal de Rondônia. Atualmente, é capital do Estado de Rondônia.

Para delimitação das etapas de vida estudadas (infância/meninice, pré-adolescência/adolescência, maturidade e velhice) considerou-se o que cita a literatura atual sobre a questão: a evolução humana sofre influências como hereditariedade, maneira de viver, clima, tipo de atividade, meio social, condições econômicas, entre outros fatores. Daí a incompletude do aspecto cronológico como ponto de partida e único estatuto para identificar cada uma das diferentes etapas em que se encontra um indivíduo. Entretanto, pela necessidade metodológica de se estabelecer parâmetros delineadores para as distintas etapas de vida; pela simplicidade para a obtenção de informações sobre uma pessoa, conforme sugerem Hoyer e Roodin (apud Schneider; Irigaray, 2008); e pela facilidade do seu uso na estratificação das distintas fases, utilizou-se prioritariamente, mas não necessariamente, a dimensão cronológica. Nos casos, por exemplo, de matrimônio e presença de filhos, independentemente da idade, as mulheres foram inseridas na fase adulta/maturidade.

Ponderando esses aspectos, e ancorados em alguns autores (Santos; Vaz, 2008; Gonçalves et al., 2013; Silva; Brasil, 2016; Schneider; Irigaray, 
2008), elaborou-se a Figura 2, que apresenta a delimitação cronológica do desenvolvimento humano utilizado neste livro.

A infância envolve as fases que vão do nascimento até a puberdade. Está delimitada em três etapas, sendo de interesse do estudo as duas últimas: segunda infância e meninice. Isso por considerar que a partir dessas etapas o indivíduo retém na memória suas vivências. A adolescência se inicia com a puberdade ou pré-adolescência e finaliza com a adolescência propriamente dita. Nessa etapa da vida, é bem marcante a diferença entre meninos e meninas, sendo o desenvolvimento delas mais acelerado do que o deles. A maturidade classifica-se em duas etapas, e vai dos 18 aos 59 anos. A fase idosa ou velhice é classificada em três etapas distintas, e inicia entre os 60/65 anos ou mais. Utilizou-se a classificação da OMS (2015) segundo a qual a fase idosa corresponde à idade igual ou superior a 60 anos para países em desenvolvimento.

No Brasil, existem ainda inúmeras variações terminológicas para referir-se à pessoa quando chega nesse ciclo da vida: idoso, velho, indivíduo da terceira idade, entre outros. Atualmente, uma nova categoria é apresentada para fazer referência a indivíduos com 75 anos ou mais de idade. É a denominada 4a idade (Gonçalves et al., 2013; Silva; Brasil, 2016).

Figura 2 - Delimitação cronológica do desenvolvimento humano considerada no estudo

\begin{tabular}{|c|c|c|}
\hline \multirow{2}{*}{ Etapas } & Subetapas & Características Cronológicas \\
\hline \multirow{3}{*}{ Infância } & Primeira infância & Do nascimento até os 2 anos \\
\cline { 2 - 3 } & Segunda infância & Dos 2 até os 6 anos \\
\cline { 2 - 3 } & Meninice & Dos 6 anos até a puberdade \\
\hline \multirow{2}{*}{ Adolescência } & Pré-adolescência & Dos $12 / 14$ anos aos $15 / 16$ anos \\
\cline { 2 - 3 } & Adolescência & Dos $15 / 16$ anos aos 20 anos \\
\hline \multirow{2}{*}{ Maturidade } & Adulto inicial & Dos 18 aos 30 anos \\
\cline { 2 - 3 } & Adulto maduro & Dos 30 aos 60 anos. \\
\hline \multirow{3}{*}{ Velhice } & Idoso jovem & Dos 65 a 74 anos; \\
\cline { 2 - 3 } & Idoso velho/4a idade & Dos 75 a 84 anos \\
\cline { 2 - 3 } & Idoso mais velho/4a Idade & Dos 85 anos ou mais \\
\hline
\end{tabular}


Como critério de inclusão para o estudo, determinou-se que as depoentes tivessem 70 anos ou mais; que tivessem nascido na região Amazônica ou que tivessem vindo para a localidade ainda na infância. A Figura 3 ilustra o quantitativo de idosas por ano de nascimento e o ano em que elas se encontravam nas distintas fases da vida.

Figura 3 - Quantitativo de idosas por ano de nascimento e o período em que se encontravam nas distintas fases da vida

\begin{tabular}{|c|c|c|c|c|c|}
\hline $\begin{array}{c}\text { Ano de } \\
\text { Nascimento }\end{array}$ & 1928 & 1930 & 1931 & 1934 & 1937 \\
\hline $\begin{array}{c}\text { Quantitativo } \\
\text { de Idosas }\end{array}$ & 1 & 3 & 1 & 2 & 2 \\
\hline $\begin{array}{c}\text { infância/ } \\
\text { Meninice: de } \\
2 \text { aos 12 anos }\end{array}$ & $1930-1940$ & $1932-1942$ & $1933-1943$ & $1936-1946$ & $1939-1949$ \\
\hline $\begin{array}{c}\text { Adolescência: } \\
\text { até os 19 anos }\end{array}$ & $1940-1947$ & $1942-1949$ & $1943-1950$ & $1946-1953$ & $1949-1956$ \\
\hline $\begin{array}{c}\text { Maturidade: } \\
\text { até os 19 anos }\end{array}$ & $1947-1986$ & $1949-1988$ & $1950-1989$ & $1953-1992$ & $1956-1995$ \\
\hline $\begin{array}{c}\text { Idosas: a par- } \\
\text { tir de 60 anos }\end{array}$ & $\begin{array}{c}\text { a partir de } \\
1987\end{array}$ & $\begin{array}{c}\text { a partir de } \\
1989\end{array}$ & $\begin{array}{c}\text { a partir de } \\
1990\end{array}$ & $\begin{array}{c}\text { a partir de } \\
1993\end{array}$ & $\begin{array}{c}\text { a partir de } \\
1996\end{array}$ \\
\hline
\end{tabular}

A fim de garantir o anonimato das idosas, e considerando que se trata de mulheres Amazônicas, para homenageá-las, elas foram identificadas no estudo com nomes indígenas, a saber: Yara, Taynara, Iracema, Janaina, Jurema, Aracy, Tayná, Anahi e Apuniã.

\section{Fundamentos para a análise dos dados}

Após a transcrição, os relatos foram submetidos à análise de conteúdo com inspiração nos procedimentos sugeridos por Bardin (2009). Essa técnica possibilita captar conteúdos sobre o problema investigado. Foram buscadas semelhanças temáticas nas respostas dos participantes, reunidas em agrupamentos temáticos, originando categorias de respostas. As categorias identificadas e analisadas foram as seguintes: a) Nascimento: local e ano; b) Infraestrutura e Segurança da localidade; c) Moradias; d) 
Família; e) Lazer: características; f) Locais de lazer; g) Tipos de lazer que praticavam; h) Brinquedos utilizados; i) Companhias no lazer; j) Restrições para o lazer.

Os dados colhidos foram discutidos e analisados à luz de teorias e conceitos diversos disponíveis na literatura, por meio da construção interativa, principalmente de aspectos socioeconômicos da época em que as mulheres eram crianças, adolescentes, adultas e idosas. Essa estratégia é orientada pelo modelo de análises qualitativas de conteúdo proposto por Laville e Dionne (1999). Por esse motivo, fatos históricos são considerados pontos de destaque nas análises dos dados.

$\mathrm{Na}$ infância das mulheres integrantes desta pesquisa, principalmente as mais velhas, a economia brasileira, em particular da Amazônia, tinha uma situação econômica específica, sofria os augúrios do fim de um dos ciclos históricos da valorização do látex no mercado internacional: era o 1 Ciclo da Borracha, ocorrido entre os anos 1879 a 1912.

Citam alguns historiadores que, na época áurea da exploração do látex na Amazônia, as ações do Governo limitavam-se à cidade de Manaus e, em alguns aspectos, a Belém, localidades de concentração da riqueza e do poder, ficando os demais Estados e, sobretudo, as localidades interioranas relegadas ao esquecimento (Wagley, 1988; Wolff, 1999). Já outras fontes mencionam que até 1920, cidades como Manaus, Porto Velho e Belém tornaram-se as capitais brasileiras mais desenvolvidas. Contavam com infraestrutura como eletricidade, sistema de água encanada e esgotos, museus e cinemas. Tudo construído por influência europeia.

Com o declínio da comercialização do látex no estrangeiro, no Governo de Vargas viu-se incrementado o $2^{\circ}$ Ciclo da Borracha, que trouxe novas esperanças à população da região. Mas foi apenas questão de tempo para constatar-se que a borracha brasileira já estava fadada ao fracasso, no sentido de comercialização internacional.

$\mathrm{Na}$ primeira década do $2^{\circ}$ Ciclo da Borracha, na Amazônia Brasileira, a presença de mulheres nos seringais era um fenômeno bastante raro. Aquelas que ali residiam já tinham seus companheiros. Usufruir da companhia de uma mulher no seringal era privilégio reservado apenas aos patrões, 
aos donos dos barracões e, quando muito, daqueles que possuíam condições de mantê-las nos seringais (Morga; Lage, 2015).

A contextualização histórica justifica-se na medida em que servirá de elemento para compreensão dos distintos ciclos de vida das idosas.

Nesse sentido, o povoamento da região, a construção da Estrada de Ferro Madeira Mamoré e o declínio da comercialização da borracha ajudam a compreender a trajetória de vida das mulheres da Amazônia.

\section{Considerações finais}

Para compreender a trajetória de lazer na vida das idosas da Amazônia, foi necessário compreender a sua simplicidade e o cotidiano em que estavam imersas nos variados ciclos da vida. Nesse contexto, foi fundamental recorrer conjuntamente à história da região e do município para melhor compreender, na essência, o lazer na trajetória dessa população pesquisada.

Por meio do discurso das idosas, identificou-se que as experiências cotidianas da infância, meninice, adolescência e maturidade permanecem vivas em suas memórias.

Apesar da metodologia utilizada, os resultados do estudo mostram o quanto a história do lazer na Amazônia encontra-se fragmentada na prática cotidiana, quando observado pelo recorte de gênero.

\section{Referências}

APERON. Agremiação Pioneiras de Rondônia. Estatuto. Porto Velho, Rondônia. 2014.

BARDIN, L. Análise de Conteúdo. 4. ed. Lisboa: Edições 70 LDA, 2009.

BOSI, E. Memória e Sociedade: lembranças de velhos. São Paulo:Tao. 1979.

CAMARGO, A. História oral e política. In: MORAES, M.(Org.). História oral. Rio de Janeiro: Diadorim, FINEP. 1994. Disponível em: <http://www.scielo.br/scielo.php?script=sci_nlinks\&ref=000132\&pid=S14144980200700030000900007\&lng=en>. Acesso em: 13 mai. 2017.

GONÇALVES, R.C.; LISBOA, T. K. Sobre o método da história oral em sua modalidade trajetórias de vida. Revista Katálysis. Florianópolis, v.10, n. esp. 2007.. Disponível em: <http://www.scielo.br/scielo.php?script=sci_ arttext\&pid =S1414-49802007000300009>. Acesso em: 13 jun. 2017. 
GONÇALVES, L.T.H. et al. Convívio e cuidado familiar na quarta idade: qualidade de vida de idosos e seus cuidadores. Rev. Bras. Geriatr. Gerontol. Rio de Janeiro, 2013. Disponível em: <http://www.scielo.br/pdf/rbgg/v16n2/11.pdf〉. Acesso em: 20 jan. 2017.

LAVILLE, C.; DIONNE, J. A construção do saber: manual de metodologia da pesquisa em ciências humanas. Porto Alegre: Artmed, 1999.

MARCELLINO, N.C. O conceito de lazer nas concepções da Educação Física Escolar: o dito e o não dito. Congresso de Educação Física e Ciências do Desporto dos Países de Língua Portuguesa, 8. 2000. Disponível em: <https://ufsj.edu.br/portalrepositorio/File/ dcefs/Prof._Adalberto_Santos2/13o_conceito_de_lazer_nas_concepcoes_da_ef_escolaro_dito_e_o_nao_dito10.pdf >.Acesso em: 29 nov. 2017

MORGA, A.E.; LAGE, M.M.L. Mulheres nos seringais do Amazonas: Sociabilidade e cotidiano. Revista Latino-americana de Geografia e Gênero. Ponta Grossa, v. 6, n. 1, p. 91-104, jan./jul., 2015. Disponível em: <http://www.revistas2.uepg.br/index.php/rlagg/article/viewFile/6603/pdf_157>. Acesso em: 18 dez. 2015.

OMS. O papel da atividade física no envelhecimento saudável. Relatório Mundial de envelhecimento e saúde. Organização Mundial de Saúde. 2015. Disponível em:<http:// apps.who.int/iris/bitstream/handle/10665/186468/who_fwc_alc_15.01_por.pdf;jsessionid=9EC5C5415524AB6F2239FB51CACA4297? sequence=6>. Acesso em: 13 jan. 2017.

POLLAK, M. Memória, esquecimento, silêncio. 1989. Disponível em: <http://bibliotecadigital.fgv.br/ojs/index.php/reh/article/view/2278/1417>. Acesso em: 13 maio 2017.

SARTORI, J. Memória de idosos. Sem Aspas, Araraquara, v. 2, n. 1, 2. 2013. Disponível em: <file://C:/Users/User/Downloads/Dialnet-MemoriaDeIdosos-6263032\%20(1).pdf>. Acesso em: 30 nov. 2017.

SANTOS, G.A.; VAZ, C.E. Grupos da terceira idade, interação e participação social. In: Psicologia e práticas sociais. (Org.). ZANELLA, A.V. et al. Rio de Janeiro: Centro Edelstein de Pesquisas Sociais, 2008.

SCHNEIDER, R.H; IRIGARAY, T.Q. O envelhecimento na atualidade: aspectos cronológicos, biológicos, psicológicos e sociais. Estudos de Psicologia I. Campinas. v.25, n.4, p. 585-593. out./dez., 2008. Disponível em: <http://www.scielo.br/pdf/estpsi/v25n4/ a13v25n4.pdf >. Acesso em: 31 ago. 2018.

SEVERINO, A.J. História oral como arte da escuta, de Alessandro Portelli. São Paulo: Letra e Voz, 2016. Disponível em: http://oaji.net/articles/2017/4613-1491246970.pdf>. Acesso em: 17 maio 2017.

SILVA, R.M; BRASIL, C.C.P. A quarta idade: o desafio da longevidade. Ciênc. Saúde Coletiva. v. 21, n.11, Rio de Janeiro, nov. 2016. Disponível em: <http://www.scielo.br/scielo. php?pid=S141381232016001103631\&script=sci_arttext >. Acesso em: 7 set. 2017. 
SPINDOLA, T.; SANTOS, R.S. Trabalhando com a História de vida: percalços de uma pesquisa (Dora?). Rev. Escola de Enfermagem. São Paulo, USP, 2003; v.37, n.2, p. 119-26. Disponível em: <http://www.scielo.br/pdf/reeusp/v37n2/14.pdf>. Acesso em: 16 dez. 2015.

SPINDOLA, T.; SANTOS, R.S. O trabalho na enfermagem e seu significado para as profissionais. Rev. bras. enferm. v.58, n.2. Brasília, mar./abr. 2005. Disponível em:<http:// www.scielo.br/scielo.php?script=sci_arttext\&pid=S003471672005000200005 >. Acesso em: 31 ago. 2018.

VIEIRA, M.C. Memória, história e experiência: trajetórias de educadores de jovens e adultos no Brasil. Tese (Doutorado em Educação) - Programa de Pós-Graduação da Faculdade de Educação da Universidade Federal de Minas Gerais. Belo Horizonte, 2006. Disponível em: <http://www.bibliotecadigital.ufmg.br/dspace/bitstream/handle/1843/ HJPB6VZL86/2000000111.pdf; jsessionid=AA53A96C287F66045480707D8E2CB504?sequence=1 >. Acesso em: 16 mar. 2017.

WAGLEY, C. Uma comunidade amazônica: estudo do homem nos trópicos. 3. ed. Belo Horizonte: Itatiaia; São Paulo: Edusp, 1988.

WOLFF. C.S. Mulheres da floresta: uma história - Alto Juruá, Acre, (1890- 1945). São Paulo: Hucitec, 1999. Disponível em: <https://periodicos.ufsc.br/index.php/esbocos/article/view/505/9810>. Acesso em: 3 ago. 2017. 



\title{
3. MANIFESTAÇÕES DE LAZER NA HISTÓRIA DE VIDA DE IDOŠAS DE PORTO VELHO: DA INFÂNCIA A MENINICE
}

\author{
Ivete de Aquino Freire \\ Ramón Núñez Cárdenas \\ Marcelo Tiago Baltazar Correa \\ Ednes Pereira dos Santos Souza
}

\section{Introdução}

Atualmente, verifica-se uma crescente preocupação em ocupar o tempo livre de crianças, principalmente aquelas pertencentes às camadas sociais mais pobres. A ideia é afastá-las das influências prejudiciais que podem de certa forma consolidar esse grupo na pobreza e na marginalidade, conforme política do Governo Federal (Brasil apud Souza, 2010).

Neste estudo, no entanto, não se pretende falar do lazer de crianças da atualidade. Pretende-se abordar como se manifestava esse fenômeno há cerca de 70 ou 80 anos atrás, quando não havia a garantia legal dessa prática. Quando as condições de vida (social, política, cultural e econômica) apresentavam-se de modo bastante distinto das condições da atualidade; quando a condição da população brasileira era de restrição, nos mais diferentes aspectos, em especial nas camadas mais pobres da Amazônia.

Se voltarmos no tempo, há cerca de sete ou oito décadas, no Brasil, podemos imaginar que a maioria da população não tinha acesso ao lazer, principalmente aqueles grupos com precárias condições de vida. $\mathrm{O}$ usufruto desse fenômeno sociocultural, em sua plenitude, era restrito às famílias mais abastadas. Isso significa que, naquela época, como na atualidade, a acessibilidade ao lazer guardava importantes desigualdades entre os indivíduos.

Nessa lógica, e considerando o exposto anteriormente, este capítulo resguarda os seguintes objetivos: a) Caracterizar as fases da infância e meninice no contexto Amazônico no período de 1930 a 1939; b) Apresentar as 
manifestações de lazer vivenciadas pelas meninas da região e residentes em Porto Velho; c) Identificar os espaços e os brinquedos utilizados; d) Levantar as principais dificuldades encontradas para as práticas de lazer; e) Discutir a relação entre os aspectos socioeconômicos e culturais e as vivências de lazer das crianças.

\section{0 lazer na infância}

Para falar de lazer na infância e na meninice, faz-se necessária uma contextualização teórica sobre essas fases da vida. A infância e a meninice, tal como as demais etapas da vida, além de serem fenômenos biológicos também trazem consigo fatores socioeconômicos e culturais. Portanto, é um equívoco afirmar, por exemplo, que crianças brincam na maior parte do seu tempo, estejam elas onde estiverem (Navarro; Prodócimo, 2012); ou que crianças são crianças em qualquer época e em qualquer lugar do mundo e, para elas, tudo gira em torno das brincadeiras (Barbosa, 2012). A frase está longe de ser uma afirmação universal.

Para abordar essa fase da vida, antes de tudo precisamos saber a quais crianças se está fazendo referência; qual a identidade socioeconômica e cultural delas; em que tempo e espaço estão inseridas. Portanto, não existe uma concepção homogênea de criança, independente do contexto social. Igualmente, o universo infantil tem sofrido alterações significativas ao longo dos séculos.

A sociedade medieval, até por volta do século XII, por exemplo, desconhecia a infância; não a representava em suas produções culturais do modo que a identificamos hoje. É provável que não houvesse lugar para a infância naquela sociedade não porque elas fossem desprezadas, mas simplesmente porque a sociedade não tinha a noção da particularidade do infantil como aquilo que distingue essencialmente uma criança de um adulto, conforme afirma Gurski (2012), orientada pelos estudos de Áries.

Apesar desses aspectos, com Kohan apud Silva (2009), percebe-se que a prática do trabalho no período medieval não era permitida às crianças. Segundo o autor, uma série de práticas sociais como jogos, ocupações, 
trabalhos, profissões e armas não estavam determinadas para idade alguma na etapa infantil. Já Andrade (2010), orientado por diversos autores, afirma que, na Idade Média, as crianças pequenas não tinham função social antes de trabalharem e destaca que era alta a taxa de mortalidade infantil. Aquelas pobres, assim que cresciam, eram inseridas no mundo do trabalho, sem qualquer diferenciação entre adultos e crianças. Já as crianças de famílias nobres tinham seus educadores e eram vistas como miniaturas dos adultos; deveriam ser educadas para um futuro de transição para a vida adulta.

Segundo Andrade (2010), no século XVI, os adultos, em especial as mulheres, começam a destinar certa atenção às crianças, reconhecidas como fonte de distração ou relaxamento, o que Ariès chamou de "crianças bibelot", expressando um sentimento de "paparicação" pela infância.

Somente a partir do século XVII, com a educação formal, começa-se a desenvolver um sentimento novo no ambiente familiar em relação à infância. A criança passa a ser o centro das atenções e a família vai the conferindo maior importância (Silva, 2009). Cita Áries (apud Silva, 2009) que a substituição da aprendizagem da família pela escola exprime também uma aproximação da família e das crianças, do sentimento da família e do sentimento da infância, outrora separados. Sendo assim, o espaço escolar guarda estreita relação com o surgimento da noção de infância (Silva, 2009).

Com a revolução industrial, no século XIX, a modernidade constrói uma nova ideia em torno da criança. $\mathrm{O}$ trabalho infantil das crianças de família pobre contribuiu para deterioração da imagem que se havia criado dessa população (Silva, 2009).

Segundo Mendonça (2011), no século XIX a criança era um ser que não se diferenciava entre os adultos; era visto como um adulto em miniatura e, em pouco tempo, assumia a força para o trabalho e os atributos para constituir a própria família.

Ainda segundo Mendonça (2011), o período da infância parecia não existir; não era percebido como uma dimensão exclusiva e única no desenvolvimento humano. Grande parte dessas anomalias deve-se à indistinção entre o conceito de adulto e o conceito de criança. 
Apesar de as especificidades da criança terem sido cristalizadas no século XVIII, no Brasil, a integridade delas só veio a ocorrer no século $\mathrm{XX}$, quando foram criadas, três grandes leis que regulam a ação do Estado na direção da criança. São elas: Códigos de menores, de 1927 e 1979, e o Estatuto da Criança e do Adolescente, de 1990 (Silva, 2009).

Segundo Souza (2007), a educação institucionalizada de crianças pequenas surgiu no Brasil no final do século XIX. As primeiras propostas de instituições pré-escolares para as crianças de menor poder aquisitivo no Brasil aparecem em 1899 (Kuhlmann apud Souza, 2007).

De acordo com Marcílio (1998), o século XX foi de descobertas, valorização, defesa e proteção da criança. Com seus direitos básicos reconhecidos, a criança passa a ser vista como é: um ser especial, com características específicas. Segundo Klebis (2010), nesse período também ocorreram mudanças importantes na educação, com crianças tendo mais acesso à escola primária, e uma renovação cultural, ainda que não satisfatória.

Cita Souza (2007) que, no período de 1930-1970, o Estado começa a se equipar de instituições voltadas à educação e ao cuidado de crianças pequenas. Vejamos alguns exemplos dessa institucionalização da educação infantil.

A pesquisa de Fraga (1988) indica as ações exploradas na área das políticas direcionadas a esse nível educacional. As novas necessidades da sociedade industrial e os dispositivos legais da Consolidação das Leis Trabalhistas (CLT) propiciam a contratação de pessoal técnico para a ação social, saúde, educação, previdência e assistência. A criação do Departamento Nacional da Criança (DNCR - 1940-1970) abriu espaço para a organização dos serviços sanitário e educativo. Em 1947, dava-se início em São Paulo a uma tentativa de expandir a rede pública de ensino primário, que culminou na criação do Serviço de Educação Primária, em 1950. Esse serviço era voltado à assistência psicológica e pedagógica e a atividades de expressão corporal e recreação, além de prestar assistência à vida familiar para a escolarização de crianças.

De acordo com Áries (apud Silva, 2009), a inserção das crianças e seus papéis sociais variam com as formas de organização social. Parece ser 
que a institucionalização da educação infantil também acompanhou esse processo. Destaca Silva (2009) que a concepção que se tem atualmente da infância, como um período da vida ou uma fase que incita uma atenção diferenciada do adulto e, por isso, merece receber um cuidado específico, nasceu somente com o advento da modernidade. A partir desse período, se confere à criança uma atenção que em nenhum outro momento da história lhe foi dada. A criança é vista, então, como um sujeito dotado de direitos (Silva, 2009).

Se, por um lado, é vasta a literatura voltada aos papéis atribuídos à criança ao longo dos tempos bem como o processo de institucionalização da educação infantil, são escassas as publicações que fazem referência à nomenclatura "lazer infantil" ao longo da história. As referências são aos termos "brincadeira" e "universo" ou "produção lúdica", alusões que seguem até a atualidade. Nesse sentido, é importante a compreensão dos termos lazer e brincadeira bem como a relação entre esses dois termos.

Pautado na visão de diferentes autores (Bramante, 1998; Marcellino, 1987; Gomes, 2004), neste trabalho entende-se lazer como uma atividade prática ou contemplativa, com características social e cultural vivenciadas num tempo conquistado socialmente, com caráter desinteressado. Nela não se busca uma recompensa extra, além da satisfação provocada pela situação em si. Entretanto, sua prática resulta em efeitos que fomentam o desenvolvimento pessoal e social.

O lazer é uma dimensão privilegiada da expressão humana, resultado da vivência de inúmeras práticas culturais. Tais práticas culturais são materializadas em atividades como o jogo, a brincadeira, a festa, o passeio, a viagem, o esporte e também as formas de arte (pintura, escultura, literatura, dança, teatro, música, cinema), dentre várias outras possibilidades. Inclui, ainda, o ócio, uma vez que este e outras manifestações culturais podem constituir, em nosso meio social, notáveis experiências de lazer (GOMES, 2004).

Segundo Gomes (2004), é possível entender a brincadeira como uma prática de lazer, atribuindo todos os significados do segundo termo ao primeiro. Portanto, quando as crianças estão brincando, estão em momen- 
tos de lazer, apesar de o termo não ser utilizado no universo infantil. $\mathrm{O}$ lazer infantil está relacionado com o mundo lúdico das crianças, que se materializa em atividades como brincadeiras e jogos. Por esse motivo, neste capítulo as práticas de lazer são nomeadas brincadeiras ou o ato de brincar.

Debortoli (2004) ajuda a compreender as características do brincar e da brincadeira de modo a favorecer a sua relação com o lazer. Segundo o autor, o brincar e a brincadeira são fenômenos culturais, identidade inalienável do humano, expressão da condição humana: cultural, histórica, ética, estética e política. $\mathrm{O}$ brincar radicalmente se manifesta como dimensão que é simbólica, constitui inserção cultural, se expressa como linguagem e como processo de elaboração de significados e sentidos coletivos, contextualizados e enraizados no universo social que o legitima. Apoiado em Vigotski, Debortoli (2004), acrescenta que o brincar só pode ser compreendido como processo de inserção em um tempo-espaço de aprendizados demarcadamente sociais. Também com orientação de Vigotski, os autores Navarro e Prodócimo (2012) acrescentam que, do ponto de vista do desenvolvimento infantil, são inúmeras as contribuições que a brincadeira pode resultar; uma delas é possibilitar à criança a passagem para um novo nível de desenvolvimento.

\section{Infância e meninice das idosas}

Os detalhamentos metodológicos da pesquisa sobre o lazer das idosas nas fases de infância e meninice estão inseridos no Capítulo 2 desta obra. Conforme dito ali, a fim de garantir o anonimato das depoentes e ao mesmo tempo identificá-las, lhes foram atribuídos, aleatoriamente, os seguintes nomes indígenas: Yara, Taynara, Iracema, Janaina, Jurema, Aracy, Tayná, Anahi e Apuniã.

No período em que essas mulheres nasceram, Porto Velho era município do Estado do Amazonas, permanecendo assim até 1940 (Gorayeb, 2015). 
Figura 1 - Identificação, local e ano de nascimento e idade das participantes do estudo

\begin{tabular}{|c|c|c|c|}
\hline Identificação & Local de Nascimento & Ano Nasc & Idade \\
\hline Yara & $\begin{array}{c}\text { Porto Velho (Com a denominação de Santo } \\
\text { Antônio: pertencia ao Estado do Amazonas). }\end{array}$ & 1930 & 86 \\
\hline Taynara & Manicoré/ Amazonas & 1934 & 82 \\
\hline Iracema & Alenquer/Pará & 1930 & 86 \\
\hline Janaina & São Carlos/Amazonas & 1931 & 85 \\
\hline Jurema & Óbitos/Pará & 1928 & 88 \\
\hline Aracy & Jaguaruana/Ceará & 1937 & 79 \\
\hline Tainá & $\begin{array}{c}\text { Boa Vista (Época em que pertencia ao } \\
\text { Estado do Amazonas) }\end{array}$ & 1930 & 86 \\
\hline Anahi & Santo Inácio/Amazonas & 1934 & 82 \\
\hline Apuana & Santarém/Pará & 1937 & 79 \\
\hline
\end{tabular}

Resgataram suas memórias de lazer nove mulheres com idade entre 79 a 88 (conforme ilustrado na Figura 1), no ano de 2016, quando foram colhidos os relatos. As fases de infância e meninice das informantes apresentam uma diferença de nove anos. Conforme se exibe na Figura 2, a mais velha delas teve sua infância iniciada em 1930, e a mais jovem, em 1939.

Figura 2 - Demonstrativo das variações dos anos em que as idosas se encontravam nas etapas de infância e meninice

\begin{tabular}{|c|c|c|c|c|c|}
\hline $\begin{array}{c}\text { Ano de } \\
\text { Nascimento }\end{array}$ & 1928 & 1930 & 1931 & 1934 & 1937 \\
\hline $\begin{array}{c}\text { Quantitativo } \\
\text { de Idosas }\end{array}$ & 1 & 3 & 1 & 2 & 2 \\
\hline $\begin{array}{c}\text { Infância/ } \\
\text { Meninice: de 2 } \\
\text { aos 12 anos }\end{array}$ & $1930-1940$ & $1932-1942$ & $1933-1943$ & $1936-1946$ & $1939-1949$ \\
\hline
\end{tabular}

Somente uma das depoentes (Aracy) não nasceu na Amazônia (conforme ilustra a Figura 1), mas se decidiu que ela faria parte do estudo, considerando que a sua família veio para Porto Velho na época do incentivo do Governo Federal para povoar a Amazônia. Tratava-se do recrutamento de nordestinos para o trabalho nos seringais da região Amazônica. Naquela época, esses trabalhadores recebiam o termo pejorativo de "arigós" e, 
atualmente, como forma de valorizá-los, são nomeados "Soldados da Borracha”. Eram homens que vinham trabalhar na extração da borracha, conforme narra Aracy.

É... (Pensando) o Governo dava passagem pras pessoa vir embora para o Amazonas, né? E o meu pai veio de Fortaleza e conseguiu passagem [...]. Quando chegou aqui a gente fico numa, numa, numa hospedaria que o Governo dava para ô ô... Aqui o pessoal chamava Arigó. Ficava tudo lá embaixo. (Aracy).

A fala de Aracy é representativa nesse contexto porque reforça os relatos históricos da chegada de nordestinos para o trabalho nos seringais da Amazônia Brasileira. Até 1960, foram milhares de nordestinos que vieram para a região com o apoio do Governo Federal em busca de trabalho.

No contexto em que nasceram essas mulheres (final da década 1920 e meados da década de 1930), a situação na região era considerada crítica, levando o Governo Federal a intervir em sua administração (Gorayeb, 2015). A partir dessa intervenção, foram criadas expectativas de desenvolvimento para a região.

Para se chegar à fase de infância das idosas depoentes, além da idade cronológica, buscaram-se as suas lembranças mais longínquas. E concluiu-se que as lembranças se iniciam em períodos aproximados ao ano de 1930, daí esta ser uma referência para os achados. Obviamente, consideraram-se também as informações daquelas depoentes que se inserem em período mais adiante.

\section{O lazer na trajetória de vida das crianças Amazônicas}

O fenômeno lazer é uma prática condicionada a diferentes fatores, tais como aspectos socioeconômicos e culturais, entre outros. Por esse motivo, analisar o universo lúdico das crianças Amazônicas, no período compreendido entre 1930 e 1949, implica necessariamente conhecer o processo social, econômico e cultural em que viviam essas mulheres. 
Referente ao local de nascimento das idosas, observou-se que todas nasceram em localidades periféricas, fora dos grandes centros das cidades, conforme relato das mesmas:

No interior do Amazonas, o nome do lugar era Santo Inácio (Anahi). Aqui pelo Amazonas mermo que naquele tempo tudo era Amazonas, né? [...]. È parece que tudo era Amazonas naquele tempo. São Carlos... [Não conclui] (Janaina).

Morava nos interiores na Vargem. [O nome da localidade de Santarém, no Pará] Costa da Saracura. Lá era um interior muito atrasado (Apuana). [Local que Nasceu] No Pará, no Lago Grande que chama (Jurema). Foi no interior do Ceará, Jaguaruana (Aracy).

$\mathrm{Na}$ narrativa das idosas, chama a atenção o caso de algumas delas que não conheceram e/ou não conviveram com os pais. É o caso de Jurema, Apuana e Iracema, por exemplo. A influência dos aspectos econômicos e culturais, interpretados como um fenômeno natural, juntamente com as dificuldades econômicas, levava naquela época os pais a darem os filhos para outras pessoas cuidarem, fossem pessoas da família ou não.

[Sobre pai e mãe]. Não lembro porque não conheci nada desses, não conheci, não conheci pai, não conheci mãe, nem conheci avó, nem avô, nem ninguém. Só conheci umas tia. Conheci duas tia e um tio e foi só. Nós morava lá no Pará no interior que chama Lago Grande. A minha história quando, como filme, porque eu me criei com a minha irmã e as minhas tias, depois que eu fiquei um tempo com as minhas tias, e depois eu passei uns anos não sei quantos lá eu era muito pequena, aí isso que me contaram, né? foi pra casa da minha irmã. Ai fiquei um bocado de tempo também com ela depois eu foi pra casa de uma familia. Agora, depois que eu me entendi eu fui para uma família. Uma família muitos anos também no interior lá de Santarém e depois eu fui pra Santarém mermo com essa família fiquei uns umas porção de tempo lá uns anos 2 anos mais ou menos eu já tava bem maiorzinha (Jurema).

Foi. Eu vim com 13 anos. Com uma família Turca. Não. Eu vim com uma família Turca. [Explicando os motivos pelos quais morava com esta 
família Turca] Porque ela me pediu pra mamãe e a mamãe me deu pra ela. Com cinco anos (Iracema).

Ela [A mãe] vivia pelas casas dos outros trabalhando. Nóis viviamos um tempo com a nossa tia. Eu vivia mais fora do que com a minha tia, que minha tia que a irmã dela que me criou. Primeiro foi meu avô que tomou conta. Ai meu avô faleceu. Ficou minha tia tomando de conta. Ai depois, nóis fomos criados assim pelas casas trabalhando (Apuana).

Apuana, sem outras oportunidades, desde criança seguiu a trajetória da mãe, de viver nas casas de estranhos obrando em trabalhos domésticos. Pelas falas das depoentes, nota-se que a ausência de organização social e familiar dificultava a criação de vínculos afetivos maiores com a família consanguínea. A trajetória da infância de Yara é outro exemplo claro de ausência de organização social e familiar.

Meus pais eram indígenas. Eram... [Pensando]. A Minha mãe era india boliviana e meu pai indio peruano. A minha infância foi dividida. Eu saí daqui de Porto Velho eu tinha 5 anos de idade, fui pra Manaus com minha mãe. Minha mãe que me criou. E de lá de Manaus eu vim com 9 anos depois que minha mãe que me criou faleceu e ai foi uma tia minha me buscar. Ai eu voltei com 9 anos de idade para Porto Velho. Só que a minha tia ela tinha uma vida irregular e na época o juizado era muito rigoroso. Ai me tomou... Ai eu fui pra casa do, do cidadão por nome Oscar, que era capitão do Portos. Lá, como eu já estudava no Maria Auxiliadora também ele continuou eu fiquei no Maria Auxiliadora estudando. Foi a melhor época da minha vida porque quando ele foi embora, ele foi transferido, seu Oscar aí não deixaram eu ir com ele. O juizado de menor não deixou eu ir com ele para o rio [Referindose ao Rio de Janeiro]. Ai eu fui para outra casa, o juiz me botou na casa de um dum doutor chamado doutor Ananias. E foi de lá que eu tive o resto da minha infância e da minha adolescência (Yara).

Entretanto, mesmo o fato de morar com a família muitas vezes não amenizava as dificuldades do cotidiano que causavam sofrimento. 
A minha mãe casou também, casou a sua primeira vez. Ela foi casada duas vezes e meu pai quando morreu, ai ela chegou a ter 4 filho, né? do primeiro, os dois primeiros morreram. Ai, quando meu pai morreu eu tava com um ano e quatro meses e minha mãe tava de resguardo no quarto filho, né? [...]. Então era um lugar muito pobre, né? sofria muito, a gente sofria demais, a minha mãe teve três filhos que ela ficou viúva primeira vez. E ai casou eu sei que ao todo foram 13 filhos só se criou parece que 7 (Aracy).

Diante das precárias condições sanitárias e de saúde da época, era comum o elevado índice de óbito infantil, a exemplo da perda dos 6 irmãos de Aracy.

Contam os historiadores que a cidade de Porto Velho era um dos grandes centros de escoação do látex, usufruindo da fase de sobrevida da comercialização da borracha (1942-1945). Entretanto, as idosas relataram que, naquela época, se tratava de uma localidade sem nenhuma infraestrutura, acompanhando o que mencionam Wagley (1988) e Wolff (1999): a localidade de maior concentração de riqueza e de poder, decorrentes das ações do Governo, era a cidade de Manaus e, em alguns aspectos, Belém; os demais Estados eram relegados ao esquecimento.

Ao falarem sobre escolaridade, constata-se que algumas idosas não tiveram acesso ao ambiente escolar. Taynara e Tayná, que residiam no interior do Amazonas, relatam a inexistência dessa instituição no seu local de moradia.

Não tinha escola naquela época! Não vou mentir porque não tinha. Eu vim aprender uma coisa depois, tá? Porque não tinha mesmo (Taynara).

Não [Não existia escola onde morava]. Aqui do lado da rua e aqui do lado não tinba nada só mato (Tayná).

Anahi afirma a existência de escola na sua localidade, narrando a precariedade de infraestrutura e a sua experiência de ascender a uma instituição com condições mais adequadas em outro município. 
Era, tinha uma escola assim coberta de palha e assoalhada. Rua, era de chão. Terra Firme. Frequentei escola. Então pra gente estudar um estudo melhor era no Humaitá que era das Freira. Ai estudei mais um pouquinho com a freira, mas não foi muito, a minhas irmãs sabe mais do que eu (Anahi).

Com a fala de Anahi, nota-se a presença das instituições religiosas na região. Entretanto, sabe-se que, por ser uma instituição privada, nem todos tinham acesso a ela.

Jurema não frequentou a escola, e ressente que a família que a criou a tenha destinado para servir aos trabalhos domésticos em detrimento dos estudos.

Estudei nada, nunca me botaram [Referindo-se à família que a criou]. Nunca pisei na porta de uma escola. Maior desgosto que eu tive foi de não aprender nada porque me botavam só pra trabalhá, né? Nunca me botaram numa escola, né? Logo, lá no começo, aonde eu morava não tinha nem, nem escola na época que eu não entendi lá, né? Quando eu vim pra Santarém foi pra casa dessa familia, não me botaram pra é estudá, né? Só era pra fazer as coisas, limpá, varrê casa, lavá louça, fazê o que era preciso, lavá essas coisas. Aí me ensinaram muito bem, mas, a leitura que é bom [Pausa]. Eu fui aprender assinar o nome por aqui já, até que eu assinava, mas agora com a vista, tô com a vista ruim, que eu não enxergo mais nada, nem adianta, né? (Jurema). Não [Dizendo que não pode estudar]. E também eu não parava. Com a idade de 7 anos eu fui viver com pessoas estranhas que a minha mãe é mãe solteira, ela tinha que trabalhar e eu queria muito aprender, muito estudar, aprender as coisas. Então ela, naquela época a pessoa davam. As mães davam pros outros [Davam os filhos para outras pessoas criarem]. Levava, essas coisa. Mas eu nunca fui em escola porque os patrões antigamente só queriam que a gente fizesse as coisa. Tomar conta dos filho, zelasse pelas casas (Apuana).

Igualmente a Anahi, outras depoentes tiveram acesso à escola, mas tal experiência foi por curto período, interrompida ainda na infância. Aracy, por exemplo, estudou até a quarta série primária. Iracema não frequentou a escola, pois a família que a criava preferia que ela tivesse ensino particular 
na residência. Usufruiu desse benefício por dois anos. Já Apuana disse que iniciou seus estudos com 50 anos de idade.

A precariedade das localidades interioranas da Amazônia era semelhante. Mesmo na cidade de Porto Velho, que usufruía alguns benefícios, tais benfeitorias não chegavam até as periferias. As idosas relatam que nos bairros em que residiam não havia nenhuma infraestrutura de água tratada/ encanada e energia elétrica.

Na época ainda não tinha luz elétrica não. A água, era água de poço. Depois foi que veio a água encanada e a luz elétrica. Veio tudo de pouco (Yara).

Olha em Porto Velho existia, mais aqui não tinha nem energia e nem água encanada (Tayná).

Era água de cacimba na época, né? Que chamava ou então ia buscar ali no Igarapé que tinha atrás do Olaria [Risos]. Aquele bendito Igarapé"(Tayná). Era luz a vela, tinha uns candeeirinho que o farol que chamam, né? (Taynara).

Perante o apogeu da comercialização do látex no mercado internacional, a solução para abastecimento de água na cidade de Porto Velho foi a instalação de três depósitos de água. Esses depósitos foram planejados em 1910 para atender às obras de construção da Estrada de Ferro Madeira Mamoré e aos moradores em geral. Esse ano marca o início da instalação dos depósitos de água da cidade, tendo sua conclusão dois anos depois.

As Três Caixas D’Agua vieram, dos Estados Unidos para a localidade, totalmente desmontadas. Instaladas no Centro antigo de Porto Velho (na parte alta da cidade), cada reservatório possuía capacidade para armazenar 1.362,731 litros de água (Borzacov, 2017). Cita a autora que os tanques foram instalados como parte dos serviços auxiliares indispensáveis 
à construção da Ferrovia Madeira Mamoré ${ }^{1}$, tais como Hospital da Candelária, serviços de distribuição de água, tipografia, serviços de porto e usina de eletricidade a vapor, dentre outros. Com base no relatório do sanitarista Oswaldo Cruz, a autora conta que a água era captada de fontes naturais e conduzida aos tanques metálicos, sendo posteriormente distribuída às residências por meio de canos de ferro.

Nesse contexto histórico, chama a atenção que as depoentes não fizeram nenhuma referência ao uso da água proveniente das três Caixas D'água, apesar de os historiadores argumentarem que os tanques abasteceram a cidade até a década de 1950.

Conta ainda Borzacov (2017) que, segundo relato de Oswaldo Cruz, as casas da localidade eram todas dotadas de salas de banhos com chuveiro; os sanitários contavam com descarga provocada. Além disso, havia vários pontos de torneiras que serviam as pias para lavagens de mãos.

As falas das depoentes contradizem esses escritos, uma vez que a existência de um conjunto de elementos que disponibilizavam a estrutura básica para acesso à água, descrita pelo sanitarista, não era uma realidade de toda a população. É bem verdade que a visita de Oswaldo Cruz à localidade ocorreu em 1910, portanto, aproximadamente em torno de duas décadas antes do nascimento das idosas. Desses fatos, pode-se deduzir que a infraestrutura descrita era acessível apenas aos moradores do centro da cidade; ou, por outro lado, que nesse interstício, se vislumbrou um declínio nas condições de moradia da população de Porto Velho. De uma forma ou de outra, o relato das idosas não acompanha a história oficial.

As idosas de Porto Velho residiam predominantemente em casas de tijolos ou madeira, entretanto, podiam-se encontrar residências de taipa.

\footnotetext{
${ }^{1}$ A Estrada de Ferro Madeira Mamoré/EFMM teve suas obras de construção executadas no período entre 1907 e 1912. Ligava a cidade de Porto Velho a Guajará Mirim (cidade brasileira, município do Estado de Rondônia, fronteira com a Bolívia). O objetivo principal da ferrovia era vencer o trecho encachoeirado do Rio Madeira, para facilitar o escoamento da borracha (à época, no auge da extração deste látex) boliviana e brasileira, além de outras mercadorias, até um ponto onde pudesse ser embarcada para exportação, no caso Porto Velho, de onde as mercadorias seguiam por via fluvial, pelo Rio Madeira e, posteriormente, pelo Rio Amazonas até o oceano Atlântico. Até então, esses produtos eram transportados com precariedade em canoas indígenas, dificuldade que aumentava diante da necessidade de transposição das cachoeiras existentes no percurso.
} 
A minha casa onde eu morava era de tijolo, era é de tijolo. Mas tinha muita casa de taipa. [Explicando a casa de taipa] É uma casa que é rodeada de o telhado é coberta de palha e é rodeado com unssss paus assim e colocado barro, barro mole e colocado ali e fazia a parede, era ali (Yara).

As casas era de madeira, tudo era de madeira só o que era de mesmo de alvenaria daquelas casas antiga era o depósito que meu pai colocava os produtos que ele recebia (Anahi).

[...] não eu morava aqui. Quando meu pai chegou comprou esse terreno aqui, que era desabitado, né? Era mata (Risos). Ele mandou limpá e construiu uma casa pra nós. Ele era prático do serviço de navegação do Madeira. [...]. Olha, casa mesmo só tinha uma deste lado que era uma casa de taipa aqui neste outro terreno aqui [Sinaliza com a mão], e tinha umas duas casas ali que na época todas eram cobertas com palba (Tayná).

A precariedade dos materiais de construção de algumas residências chama a atenção para a aparente não habitabilidade. Entretanto, o cenário dessas habitações parecia ser semelhante nas zonas periféricas da região, como se constata na fala de Apuana, que nasceu numa pequena localidade de Santarém, no Estado do Pará.

As casas tudo eram de palha, chão puro batido, né? Que chamava. Quando enchia de água fazia do giral é, uma, estilo de uma (Pensando) jangada. Só que a jangada molha e o assoalho fica normal. A gente morava lá (Apuana).

Entretanto, a semelhança das casas decorria mais da similaridade da situação socioeconômica do que do local de residência. Wiilian Haverly Martins, no seu romance Capricho do absurdo: a morte prematura da República Socialista do Guaporé (Martins, 2012), menciona as características de um casarão de um dos maiores seringalistas da região, que residia no interior, mas resolveu morar em Porto Velho, em razão da crise da exportação da borracha. Descreve o autor:

\footnotetext{
${ }^{2}$ Armação de madeira semelhante a estrado ou palanque, suspenso e preso pelo lado de fora da janela da casa. Serve como pia, para lavagem de louças, bancada para preparação de alimentos, entre outras utilidades no lar.

${ }^{3} \mathrm{Piso} /$ chão da residência.
} 
Tratava-se de um casarão colonial, com dois pisos, varandas em arcos circundavam toda a casa, com samambaias gigantes pendendo. Fora da casa, observava-se imenso jardim com roseiras. $\mathrm{Na}$ sala, cadeiras confortáveis de cana da índia, poltronas de couro curtido e mesinhas com revistas importadas enfeitavam o espaço (Martins, 2012).

Apesar da precariedade das residências, algumas boas lembranças da época foram relataram pelas idosas. Disseram que não havia muito problema com falta de segurança, pois eram locais tranquilos e seguros para viver.

[Antigamente] Não tinha essa matança que tem agora, né? (Yara).

Meu pai, quando era dia de sábado era de reunir aqueles freguês dele tudo para aconselhar. Ele, quando era assim de prender uma pessoa, ele levava para Humaitá a cidade. É, lá que tinha cadeia. Mas, era difícil, mas ele era delegado no interior, meu pai (Anari).

Anahi ainda conviveu diretamente com compra e venda da borracha, apesar do declínio da exploração desta matéria prima na região.

Olha, eu nasci num lugar que tomava de conta, meu pai era gerente era o tempo da borracha e ele gerenciava lá e era até delegado do interior um por nome Santo Inácio é um lugar; o lugar era Paraíso que morava chefia, né? Os dono desse lugar e meu pai gerenciava. Fornecia café, tinha café. Cafezal, que ele butava a freguesia pra apanbar esse café para ir para fábrica, lá para Manaus que ia muita Castanha, que ele a recebia. Borracha, peixe. Era! (Anahi).

Com relação à disponibilidade para o lazer, Moura e Souza (2013) destacam que, no decorrer da vida, se percebe que a quantidade de tempo livre é maior na infância e adolescência, diminuindo na fase adulta e aumentando com a aposentadoria. Entretanto, parece que a trajetória de vida de algumas mulheres do grupo não acompanhou essa realidade.

Pelos depoimentos, constataram-se reduzidas práticas de lazer dessas mulheres, tanto na infância quanto na meninice. 
Tinha não, tinha não [Dizendo que não tinha momentos para brincar], eu não teve infância não. Eu cresci foi trabalhando mermo [Risos]. Eu sei lá quantos anos eu tinha, só sei que eu tava grandinha já, aí me botava pra trabalhar na roça, fazer serviço de casa, varrê quintal de manhã bem cedo. Eu não teve infância não minha filha, não. É, foi criada na marra por aí (Jurema).

[...] Então, eu não tive infância num. [...] Muito difícil, muito difícil, era muito difícil. A brincadeira pra nóis, só dia de domingo. Quando nóis tava pro interior nóis ia pra roça desde da idade dos 7 anos a gente já vivia pelo roçado ajudando a mãe (Apuana).

Olha a gente tinha hora pra tudo eu comecei pequenininha que lá, ô, ô... Ofício do pessoal das mulheres era que lá se trabalhava só em com carnaúba negócio de Carnaúba. As mulheres fazia chapéu das Palhas de Carnaúba então desde pequenininha já comecei ajudar minha mãe. Fazia a trança, depois costurava o chapéu, chapéu, chamavam de carregação que era para embarcar não sei para onde. Não [Que não brincava]. Só brincava aos domingos de sete até meio-dia (Aracy).

A literatura atual aponta que, em grande parte das sociedades contemporâneas, através do ato de brincar, a criança se "auto descobre", aprende sobre a realidade e torna-se capaz de desenvolver seu potencial criativo (Siaulys apud Queiroz; Maciel; Branco, 2006). Com base em inúmeros estudos, essas autoras citadas mencionam que a brincadeira é importante para a criança porque, além de contribuir na promoção do seu desenvolvimento global, também incentiva a interação entre os pares, a resolução construtiva de conflitos e estimula a formação de um cidadão crítico e reflexivo.

Os relatos de Jurema, Apuana e Aracy indicam que ainda muito pequenas já eram utilizadas como força de trabalho. Apuana e Jurema afirmam categoricamente que "não tiveram infância", ou seja, têm consciência de que foram desassistidas; não usufruíram dos benefícios dessa etapa da vida. Sem direito a brincar, sem acesso à escola e contribuindo para o sustento familiar, essas mulheres tiveram praticamente suas infâncias rou- 
badas, na medida em que nunca tiveram reconhecidas suas especificidades de crianças e seu lugar como sujeito de direitos. Daí concluir-se que o ato de brincar é uma ação mediada pelo contexto sociocultural e econômico.

Considerando o olhar do adulto para as crianças daquela época e daquele contexto, parece que o Código de Menores de 1927 não se efetivava. Hoje, se sabe que no Estatuto da Criança e do Adolescente, datado de 1990, entre outros princípios, consta "proteção integral à infância", que passa pelo direito à educação, um requisito básico para qualquer indivíduo em pleno desenvolvimento.

Conforme afirma Gurski (2012), a experiência do brincar na infância é um dispositivo de criação, que se faz presente quando algumas condições da infância são mantidas. A vivência lúdica é importante na medida em que contribui para o desenvolvimento humano e social das crianças.

Apesar de inicialmente a maioria das depoentes negarem a presença de momentos lúdicos em suas vidas durante a infância, depois de um tempo de conversa externavam alguns momentos lúdicos. É compreensível, pois as parcas lembranças de lazer, por vezes, são abafadas pelo cotidiano de trabalho que ressalta nas memórias.

Entre os espaços de práticas de lazer na infância, foram citadas as ruas da cidade e a escola. Recorda-se que as ruas, conforme já mencionado anteriormente, não contavam com nenhuma infraestrutura de saneamento. Entretanto, ao mencioná-las como espaço de brincadeira, as depoentes não fazem referência à ausência de benefícios nesses espaços. Citam, como um dos motivos para esse uso, o pouco trânsito de automóveis.

Eram na rua, eram na rua porque antigamente não tinha carro não tinha esse movimento que tem. Então nos brincávamos na rua. Todo mundo, não tinha esse negócio de ficar trancado, era todo mundo na rua mesmo correndo (Yara).

O destaque dado ao uso das ruas como local de brincadeira, descrito por Yara, contrasta com a realidade de algumas localidades urbanas brasileiras. $\mathrm{Na}$ atualidade, o próprio local de moradia de Yara parece já 
apresentar alguns impeditivos para o uso da rua como espaço de lazer. Justifica-se essa impressão quando a entrevistada diz que: antigamente “[...] não tinha esse negócio de ficar trancado, era todo mundo na rua mesmo correndo [...]. Não tinha essa matança que tem agora”. Essa fala parece fazer referência à violência atual nas ruas, que limita a presença das pessoas fora de suas moradias.

Gostava de brincar de bola. É, gritava muito, gritaria. Não, lá dentro do colégio mermo, só dentro da escola. No parquezinho lá pra brincar (Janaina).

Já Anahi não usufruía da escola como um possível espaço de divertimento.

Não, [Afirmando que na escola não brincava] só tinha aquela pausazinha que a professora fazia, né? Depois a gente continuava estuda. Ai, é, para casa às 11 horas, na hora (Anahi).

Outro local citado de lazer foi o Cine Brasil, que na época era o único cinema de Porto Velho. A Praça Marechal Rondon também é citada como um local de passeios aos domingos.

Olha na época tinha cinema, tinha o Cine Brasil, tinha a Praça Marechal Rondon que era o chique dos Domingos e o povo ia passear na praça (Tayná). Tinha praça. A praça [Pensando] lá embaixo ali, perto. Lá, lá embaixo, é lá do centro, sim, já tinha, já tinha aquela praça. Era a única praça que tínhamos era aquela. [Afirmando que era espaço para brincadeiras]. Lá, é, de brincadeira, passeava, tinha retreta no, aos domingos. É a música da Guarda Territorial lá era. E lá juntava que, lá juntava o pessoal de Rondônia tudo lá, adultos e criança. Todo domingo, todo domingo, ai tinha o Cinema Brasil o pessoal ia pro cinema quando saía ai depois veio o Resk, o cinema grande, de potência, né? Ai vinha e ai tinha o de tarde e a noite. Mas de noite quando saía inda iam passear na praça (Yara).

Apesar da presença de lazer na vida das idosas quando criança, constata-se, conforme cita Bruhns (1997), que os espaços descritos eram 
reduzidos a pequenas proporções, escasseando as oportunidades dessa prática àquela população. Diante da precariedade de espaços e de oportunidade de lazer, o momento de estudar o catecismo era entendido como uma oportunidade de diversão, conforme mostra Anahi.

Assim de lazer, assim [Pensando]. É, Tinha uma igrejinha que eu quando era de tarde tinha uma senhora que ensinava nós assim pá, rezar catecismo. E quando já tava maiorzinha dançava que tinha dança e tinha essa senhora essa professora que ensinava nóis, negócio de catecismo. Era dentro da Vila era. Era tinha uma escola assim coberta de palha e assoalhada. [...]. Minha filha, de brincar? Assim, de dança, né? De dança, de boneca. Antigamente de brincar muito de boneca. Hoje em dia é difícil, né? (Anahi).

Os espaços de brincadeiras de Apuana se limitavam à residência em que estivesse morando naquela ocasião, já que, durante a infância, ela residiu com várias famílias.

A gente, a gente brincava mesmo, às vezes, nas casa das pessoas que a gente morava (Apuana).

Destaca-se que, mesmo com cerceamento da infância, visualizado na rotina dura de trabalho, algumas meninas se comportavam como criança. $\mathrm{O}$ lúdico, como uma necessidade infantil, se manifestava ainda que suprimido pelas determinações dos adultos. Nesse caso, o lazer desponta como um refúgio, um momento em que se permite ser criança e apenas brincar. A lei do lazer, instituída muitas décadas após a meninice das idosas, vem suprir a ausência de parâmetros legais inexistentes naquela época.

$\mathrm{Na}$ dinâmica da sociedade moderna e urbana nas décadas entre 1930 e 1940, período em que as depoentes encontravam-se na fase infantil, as práticas de lazer, no Brasil, acompanhavam a conjuntura sociopolítica e cultural da época. Sob o Governo de Vargas, vivia-se a implantação do denominado Estado Novo. As atividades esportivas e de lazer, entre outras, eram controladas pelo Departamento de Imprensa e Propaganda (DIP), cujas atribuições eram de supervisionar o turismo, censurar o teatro, cinema, 
atividades esportivas ou recreativas de todos os tipos, bem como os rádios, a literatura social ou política e a imprensa (Gomes apud Almeida; Gutierrez, 2006). No âmbito do lazer, o foco estava em São Paulo, cidade privilegiada com a criação de parques infantis. (Gomes apud Almeida; Gutierrez, 2006).

A Amazônia, igualmente a outras regiões, não recebia tais benefícios, embora a localidade, em especial a cidade de Porto Velho, vivesse sob a perspectiva de um contexto socioeconômico alentador.

Apesar do desastre econômico decorrente da crise internacional da comercialização da borracha (1 Ciclo), no Governo de Vargas, as projeções acenavam para uma fase de transição: da falta de perspectivas de desenvolvimento, passa a ser vista como uma localidade inserida nas políticas elaboradas para todo o Brasil, especialmente para a região do Guaporé (Gorayeb, 2015). A expectativa era em alguma medida resgatar o período áureo da extração da borracha. Desse modo, instalou-se o $2^{\circ}$ Ciclo da Borracha na região, no período entre 1942-1945. Mas a ausência desse período histórico na narrativa das mulheres nos leva a deduzir que nenhuma importância marcante foi observada no cotidiano delas com tal acontecimento.

Em Porto Velho, os espaços institucionalizados de lazer permaneceram os mesmos espaços do início do século. Limitavam-se à praça e ao cinema. $\mathrm{O}$ cinema, de uso limitado pela necessidade de pagamento para garantir o acesso; e ambos, com algum nível de restrição, por se concentrarem na zona central da cidade, e as depoentes residirem na periferia da localidade.

No interior do Amazonas, a realidade não era diferente.

Não, minha filha [Dizendo que não tinha lazer]. Só mesmo no Humaitá que era tempo do festejo de Nossa Senhora que ela e a gente ia para lá o festejo, o festejo era Nossa Senhora, missa, arraial é [...]. Não minha querida [Reafirmando que não tinha lazer]. Só quando eu tinha esse negócio de festa como eu tô te dizendo a gente ia pro Humaitá que era esse o passeio melhor que tinha para a gente fazer era lá (Anahi). 


\section{As brincadeiras citadas por algumas idosas foram Roda, Pião, Escon- de-Esconde, Barra ou ir para o cinema. Após o filme, ficar na praça para assistir a retreta.}

Era de roda, era... pião, esconde-esconde, de barra. Era essa nossas brincadeiras quando no tempo de criança. [...]. Brincava de barreira. É barra. Jogar barra. Jogar bola. Quem pegar a bola joga a barra. Um pegava e jogava pro outro. Naquela época a bola era feita é de, de feita de balata. Balata é tipo borracha, tipo borracha da seringueira. Eles faziam sapato, faziam aquelas botas (Yara).

Era, brincava coisa de menino mesmo de, correr. Elas não deixava. Ver gente correr, ia para casa para merendar, né? voltava da [Interrompe]. Ela tomava coisa da aula, né? dava da lição, aí a gente vinha para casa (Anahi). Boneca, chorava por boneca fazia aquela rodinha assim, botava as boneca, dançava as boneca, casava os boneco. Brincava de bola até hoje eu gosto de bola olha [Fala sorrindo]. [...]. Eu fui criada só com a mãe, incentivava, eu gostava de brincadeira sabe assim eu tirava aquelas folhas bonita do mato enrolava lá num, num sabugo de milho alguma coisa fazia uma boneca todo jeito eu inventava brincadeira, eu com minha irmãs (Taynara).

Brincava de boneca. Gostava de brincar de bola (Janaina).

Não, brinquei. A gente tinha brincava com a minha irmã sabe qual era as minhas bonecas? Sabe que, que era as minhas bonecas? [Risos] Você vai se admirá, não tem açaizeiro, não tem? Não, não dá um cacho, né? Não tem aquelas boneca, aqueles coisas que agarra no cacho, no pé? Ai quando a pessoa tira o cacho, não fica aquela coisinha? É aquele formato que parece uma bundinha, assim. Ai, cortava assim. Fazia vestido de minha boneca. [...]. É só esse tipo de brinquedo e não tinha não. Lá não tin ha nada (Jurema).

Quando nóis tava no interior, a gente brincava de casinha, de boneca, de costureira. A gente subia nos galho de cacoeiro [Cacaueiro]. O outro, a gente botava o pé e manejava que era máquina [De costurar]. Ai, a gente fazia as roupinha. Tudo de palha. Folha de cacoeiro, enfiado com tala, era as linha. Nossas brincadeira eram assim (Apuana).

Fazer uma casinha, amava uma coisa assim, ia de palha, né? Ai era as comadre, era só as primas, né? uma ficava ali outra ali. Panelinha de Barro. É que eu tinha umas prima da minha mãe fazia esses materiais. Tudo 
de Barro, né? naquela época era pote que eles fazem, pote desse tamanho [Demonstra com as mãos o tamanho dos potes]. Bacia, prato, usava tudo de Barro. Eles fazem, depois cozinha no fogo, né? Aquilo, panela, tudo a gente mandava fazer tudo pequenininho que era para a gente brincar. (Aracy).

[...]. A gente brincava de, de como é que era, era? [Pensando]. Que eu até esqueci. Que sentava todo mundo assim [Demonstra com as mãos]. Ai ia contá um e quando chegava no fulano de tal, ai é correr atrás da gente entende? [...]. É, é então de roda, né? Segura assim [Demonstra com as mãos]. Ai [Não conclui]. Roda, eu caí muito fazendo um corte assim. Eu cheguei a [Não conclui]. Eu cheguei a cair assim. Que eu já tava dormindo, que eu dormia demais e chupava o dedinho (Aracy).

Taynara,Jurema, Yara, Aracye Apuana tinham acesso limitado a brinquedos industrializados, seja pela indisponibilidade comercial dos produtos, seja pelas dificuldades financeiras das famílias. Perante a necessidade de brincar e de ter acesso a brinquedos, elas relataram que confeccionavam seus artefatos lúdicos. O sabugo de milho, os cachos de açaí, a borracha da seringueira em seu estado bruto para comercialização e galhos de cacaueiro, no universo lúdico daquelas crianças, se transformavam em brinquedos. A intimidade com a floresta Amazônica e os recursos que ela oferecia demonstram a estreita relação cultural das crianças com os objetos naturais produzidos ali.

Chama a atenção o uso de osso de carneiro, seco ao sol, na confecção de bonecas, conforme descreve Aracy. Isso porque, apesar de não se tratar de um recurso específico da região Amazônica, a criatividade aparece fortemente aliada à disponibilidade e à cultura na qual a criança estava inserida. Aracy nasceu no nordeste e ali tinha acesso a esses restos de animal.

A boneca era de osso de, de [Não conclui]. Quando comprava, tinha negócio de carneiro, né? pra fazer panelada, né? aqueles osso de bode colocava no sol aí faziam aquelas boneca que era boneca, então boneca de pano (Aracy).

Essa demonstração de intimidade com a natureza e seus recursos está em consonância com que afirma Navarro e Prodócimo (2012), a par- 
tir dos estudos de Brougère. $O$ autor explica que o brincar não pode ser separado ou isolado das influências do mundo, pois não é uma atividade interna do indivíduo, mas é dotada de uma significação social. Isso acontece porque a cultura lúdica não está separada da cultura geral em que a criança está inserida. Essa prática também se apoia no dizer de Benjamin (apud Gurski, 2012): “as crianças não constituem nenhuma comunidade isolada e os seus brinquedos não dão testemunho de uma vida autônoma e segregada, mas é um mudo diálogo entre a criança e o povo". O uso de diversos recursos naturais para a confecção de brinquedos indica algumas formas de como esse grupo social se relacionava com o meio ambiente: em total sintonia com a ecologia. Essa harmonia também acompanha o dizer de Werneck e Isayama (2001), quando afirmam que, nas práticas de lazer, os sujeitos não são meros objetos desprovidos de histórias de vida particulares, mas atuam em consonância com as questões culturais, políticas e sociais mais amplas que os constituem.

Para outras crianças, um contato tão próximo com a natureza não era permitido, a exemplo de brincadeiras no rio, conforme narra Jurema.

Eles não deixavam a gente ir também [Brincar no rio]. Tinha nem, tinha só para só tomar banho lá e voltar. Porque tinha medo, né? De, a gente ficá lá... [Pensando] e se afogar (Jurema).

Uma das idosas relata que seu lazer era viajar com os pais que estavam a serviço, e brincar com animais encontrados na praia.

A minha infância lá era atrás de bicho na praia, viajar, gostava muito de fazer viagem fazer frete de Humaitá pra Amazonas, Manicoré(Taynara).

Outros brinquedos mais convencionais também eram construídos no seio da família, tais como as bonecas de pano, que acompanham a sociedade e permanece, em alguma medida, até os dias atuais. Também se presenciavam, ainda que de modo bastante limitado, os brinquedos industrializados, tais como bolas, bonecas, petecas e cordas. 
Brincava de boneca (Janaina).

Boneca, boneca. Às vezes minha mãe fazia de pano, né? De tecido (Anahi). De bola, de peteca [Risos]. Olha, era as mesmas quase. Brincar de roda no recreio, brincar de bola, pulá corda. Quem comprava era minha a mãe [Risos] (Tainá).

Tinha brinquedo. Era difícil, mas meu pai conseguia a gente ganhar de presente que o patrão do meu pai ele quando vinha trazia para dar de presente assim, Natal (Anahi).

Com Taynara constata-se o quanto a brincadeira preparava precocemente para a vida adulta. Com orgulho, ela afirma que as brincadeirinhas de cozinhar as prepararam para, com apenas 10 anos de idade, estar apta para cozinhar uma tartaruga, prato bastante apreciado na região e atualmente proibido diante da ameaça de extinção desse animal. Pelo que narra o romancista Martins (2012), parece que, até aproximadamente a década de 1960, era comum na região o consumo de carne de animais silvestres, tais como tartaruga, paca, capivara e anta, entre outros. Nesse período, a carne de vaca vinha da Bolívia e a carne de caça era mais acessível. Daí a naturalidade com que Anahi afirma ter aprendido a preparar alimentação com carne de tartaruga.

Brincava [Fala com ênfase]. Gostava muito de cozinhar, panelinha essas coisa, né? Cozinhava e quando eu tava com 10 anos podia quebrar uma tartaruga que eu dava conta. Fazia todo tipo de prato (Taynara).

As companhias de brincadeiras das idosas quando crianças eram aquelas convencionais, igualmente às dos dias de hoje.

Brincava com os meus irmãos [Interrompe]. Vizinho, era muito bom, sabe? (Taynara).

É, é que eu tinha umas prima da minha mãe, fazia esses materiais tudo de barro... [Pensando] (Aracy).

Irmãos, vizinhos, vizinhos. Brincadeira de roda, brincadeira boa que esse [Interrompe]. Agora ninguém vê mais. Agora é só tico tico no telefone, né? (Taynara). 
Ab! Minhas colegas. Sempre a gente se reunia ou aqui em casa ou na casas das amigas. A gente se reunia pra conversar, pra dançar, pra brincar (Tainá). Com as filhas da vizinha (Janaina).

Com meus vizinhos (Anahi).

Apesar dos momentos de lazer, as idosas também destacam as restrições que tinham para essa prática. Só poderiam brincar após o cumprimento das atividades domésticas e nos dias e horários marcados para o lazer; por vezes, com a supervisão das mães, conforme fragmentos apresentados a seguir.

É às vezes pouco, né? Porque a mãe pegava muito no pé da gente não tá assim soltas, assim muito. [...]. Brincava, assim, diferente, quer dizer, assim como eu tô te dizendo por que a gente num antigamente as mães não soltava as filha principalmente mulher assim pra tá soltas na rua e na casa dos vizinhos tinha horário da gente brincar. De manhã, e manhã ir para aula quando chegava eu tinha o almoço, já tinha alguma coisa para fazer, né? Vai ajudar as mãe [...]. Brincava, eu brincava mas como tô te dizendo tinha o horário (Anahi).

Só brincava aos domingos de sete até meio-dia [...]. Era só prima, com prima era a família. Ali era uma família grande, né? Ai era assim, só que era assim, a gente brincava ai quando era aquela hora, a mamãe guarda tudo e vão deitar um pedaço para amanhã tá todo mundo descansado. E durante a semana ninguém sabia o que era brincar (Aracy).

Tainá e Iracema foram taxativas em afirmar que não se recordam de momentos de brincadeira durante suas infâncias. Os motivos apresentados variam entre a dedicação às obrigações com os trabalhos domésticos e a escola, e não terem permissão para esse tipo de atividade.

Olha eu acho que nesta época a gente nem tinha tempo de brincar que, que não tinha vizinhos, né? É só estudava e vinha pra casa, ajudava fazer o serviço de casa que a família era pequena, meu pai viajava ficava eu e minha mãe. (Tayná). 
Ela [Referindo-se a mulher que a criava, denominada pela depoente de Turca] não deixava a gente brincar. Ficava lá com ela (Iracema).

Outras idosas, que afirmaram ter seus momentos de brincadeira, também narraram já terem responsabilidades de trabalho ao ajudarem nas atividades para a subsistência da família, conforme conta Aracy, que veio do Nordeste.

Olha a gente tinha hora pra tudo eu comecei pequenininha que lá o ofício do pessoal das mulheres era, que lá se trabalbava só em com carnaúba negócio de Carnaúba. As mulheres fazia chapéu das palhas de carnaúba, então desde pequenininha já comecei ajudar minha mãe fazia a trança depois costurava o chapéu, chapéu chamavam de carregação que era para embarcar não sei para onde (Aracy).

A presença frequente do trabalho na vida de algumas dessas mulheres quando crianças extrapola o âmbito familiar.

Com a idade de 7 anos eu fui viver com pessoas estranhas [...]. Os patróes antigamente só queriam que a gente fizesse as coisas. Tomá conta dos filho, zelasse pelas casas. [...] Quando não tava no roçado tava na cidade pelas casas das pessoas, pra aprender. Mas geralmente aprendia outras coisas doméstica que nóis [Não conclui] (Apuana).

Depois que eu tava maiozinha trabalhava. Eu sei lá quantos anos eu tinha, só sei que eu tava grandinha já. Ai, me botava pra trabalhá na roça, fazê serviço de casa, varrê quintal de manhã bem cedo. Eu não teve infância não minha filha, não. É, fui criada na marra, por aí. Não! Eu fui trabalhá, ajudá a fazê as coisas lá com ela [A mulher que a criava]. Não me pagava, né? Me davam o que precisava, né? Roupa, sapato, remédio, né? Essas coisas. Ganhava dinheiro não (Jurema).

Apuana diz que seu cotidiano era dividido entre as atividades da roça e os trabalhos domésticos nas casas das famílias. Afirma que estava na casa de terceiros "para aprender". A necessidade de manter sua subsistência e às vezes ajudar a família aparece disfarçada como oportunidade 
de aprendizado. Em realidade, essa prática escondia severos dispositivos didáticos de sobrevivência e/ou preparação para a vida adulta, baseada na prática de trabalhos domésticos.

Jurema narra experiência semelhante. Trabalhava em troca de casa, comida e roupa. Não frequentou a escola. Esse comportamento familiar era ocorrência comum por volta do século XVI, conforme pontua Silva (2009). Cita o autor que logo que as crianças eram consideradas capazes de dispensar a ajuda da mãe ou da ama, misturavam-se com os adultos para aprenderem os afazeres necessários para a vida em sociedade, isto é, um ofício.

A cultura da época juntamente com as dificuldades financeiras das famílias não permitia, por parte da maioria dos adultos, a destinação de um programa de lazer para as crianças, tal como na atualidade. Muito menos quando se tratava de crianças indígenas. Em seu romance, Martins (2012) descreve um exemplo de como as meninas indígenas vinham parar em prostíbulos de Porto Velho ou eram abrigadas em casas de família para atender aos trabalhos domésticos. Destaca-se que, nessa época, já existia o Serviço de Proteção ao Índio (SPI), instituído em 1910, sendo substituído em 1967 pela Fundação Nacional do Índio (FUNAI) (Heck; Loebens; Carvalho, 2005; Estácio, 2009).

Daquela época, se nota o trato diferenciado com as crianças, quando comparado com os dias atuais. Relata Anahi que permitir que as crianças brincassem muito significava "deixá-las soltas".

"É. Às vezes. Pouco, né? [Explicando que brincava pouco]. Porque a mãe pegava muito no pé da gente não tá assim soltas, assim muito"(Anahi).

A vida das idosas durante a infância foi marcada por uma educação rígida, com sérias restrições ao lazer e, em alguns casos, com responsabilidades de trabalho de adultos. Á época, por questões sociais e culturais, as famílias não tinham condições de entender a criança com necessidades e direitos, tal como na atualidade. Hoje se sabe que uma das atividades mais importantes no mundo infantil é a brincadeira e, para isso, mais do que brinquedos, há que dedicar tempo. A partir do que diz Caldas 
(apud Ploner, Michels, Oliveira; Strey, 2017), pode-se afirmar que não há uma infância em geral, e sim infância de criança de família rica e infância de criança de família pobre; criança com acesso à educação formal de qualidade e ao lazer; e crianças trabalhadoras e sem acesso à escola; crianças oriundas de localidades como sul e sudeste do Brasil e crianças da Amazônia; crianças de hoje e crianças de 70 ou 80 anos atrás.

\section{Considerações finais}

As narrativas das vivências lúdicas das idosas na infância e na meninice, como não poderia ser diferente, são marcadas fortemente por suas trajetórias de vida. Sem a tutela dos pais, a maioria delas foi criada por outras famílias, sob um regime rígido de trabalho que variava entre a roça e os labores domésticos. A infância das meninas pobres parecia ter sido eliminada da região. Naquela época, Porto Velho fazia parte do Estado do Amazonas e era uma localidade inóspita.

Entretanto, como uma necessidade humana, o ato de brincar se manifestava no cotidiano das crianças, ainda que de modo restrito. Havia alguns momentos de brincadeiras e a infância dessas mulheres sobreviveu, apesar da simplicidade dos brinquedos. As restrições ao lazer decorriam, sobretudo, da falta de tempo destinado a essa atividade, sendo as brincadeiras vivenciadas praticamente em momentos furtivos. Por inúmeras vezes, a responsabilidade do trabalho foi colocada como um impeditivo para brincar.

$\mathrm{Na}$ ausência de brinquedos industrializados, os recursos da natureza davam asas à imaginação infantil, à fantasia lúdica, e tais experiências eram vividas com grande intensidade e satisfação. Esses aspectos se apresentaram como importantes na bagagem sociocultural do universo lúdico das idosas na infância.

Pelos relatos, constatou-se que as principais memórias da infância e meninice de grande parte das idosas foram construídas com base no trabalho, como principal referência cotidiana e único caminho para a sobrevivência. Desse modo, o desenvolvimento das potencialidades, criatividade, 
imaginação, valores morais, sentimentos e personalidade das idosas se deu mais com base na ideologia do trabalho do que nas vivências lúdicas.

As nove mulheres que participaram deste estudo são sobreviventes daquele ambiente inóspito que era Porto Velho. Possivelmente, os furtivos momentos de brincadeira tenham garantido a saúde mental dessas crianças, hoje idosas.

\section{Referências}

ALMEIDA, M.A.B.; GUTIERREZ, G.L. O Governo Vargas e o desenvolvimento do lazer no Brasil. Revista Digital, Buenos Aires. Año 10. n. 92. jna., 2006. Disponível em: $<$ http://www.efdeportes.com/efd92/vargas.htm>. Acesso em: 2 abr. 2017.

ANDRADE, L.B.P. Educação infantil: discurso, legislação e práticas institucionais. [online]. São Paulo: Editora UNESP. São Paulo: Cultura Acadêmica, 2010. Disponível em: < http://books.scielo.org/id/h8pyf/08 >. Acesso em: 20 set. 2017.

BARBOSA, C. As brincadeiras das crianças no século passado. Pensador. 2012. Disponível em: <https://www.oestegoiano.com.br/noticias/edicoes-anteriores/as-brincadeiras-das-criancas-no-seculo-passado.> Acesso em: 20 set. 2017.

BORZACOV, Y. P. A história das três caixas d'água. Instituto Histórico e Geográfico de Rondônia. Academia de Letras de Rondônia. Disponível em: <http://rondoniaovivo.com/ noticias/ahistoriadastrescaixasdaguaporyedaborzacov/11896>. Acesso em: 20 set. 2017.

BRAMANTE, A.C. Lazer: concepções e significados. Revista do programa de pós-graduação interdisciplinar em estudos do lazer. v. 1, n. 1, 1998. Disponível em: <https://seer. ufmg.br/index.php/licere/article/view/4226 >. Acesso em: 20 set. 2018.

BRUHNS, H.T. Relações entre Educação Física e o lazer. In: BRUHNS, H.T. (Org.). Introdução aos estudos do lazer. Campinas: Unicamp, 1997.

DEBORTOLI, J.A.O. Brincadeira. In: GOMES, C.L. (ORG.). Dicionário crítico do lazer. Belo Horizonte: Autêntica. 2004.

ESTÁCIO, M.A.F. Encontro Anual ANDHEP, 5. Direitos Humanos, Democracia e Diversidade. Universidade do Estado do Amazonas. UEA/UFPA/Belém/Pará. GT 8. Culturas e territórios indígenas, quilombolas e ribeirinhos e direitos humanos. Belém, 2009. Disponível em: <http://www.andhep.org.br/anais/arquivos/Vencontro/gt8/gt08p06.pdf>. Acesso em: 5 out. 2017.

FRAGA, L.M.V. Mal necessário: creches no departamento nacional da criança (19401970). Cadernos de pesquisa, São Paulo, n.67, p.3-16, nov. 1988. Disponível em: <http:// publicacoes.fcc.org.br/ojs/index.php/cp/article/view/1215/1220 >. Acesso em: 20 out. 2017. 
GOMES, C.L. Lazer. Concepções. In: GOMES, C.L.(Org.). Dicionário crítico do lazer. Belo Horizonte: Autêntica. 2004.

GORAYEB, A. Território Federal do Guaporé. Coluna do Fundo do Baú. 2015. Disponível em: <http://www.newsrondonia.com.br/noticias/territorio+federal+do+guapore/63083>. Acesso em: 23 jul. 2017.

GURSKI, R.O lugar simbólico da criança no Brasil: uma infância roubada? Educ. Rev. Belo Horizonte, v.28, n.1. 2012. Disponível em: <http://www.scielo.br/scielo.php?script=sci_arttext\&pid=S010246982012000100004\&lng=en\&nrm=iso\&tlng=pt >. Acesso em: 21 set. 2017.

HECK, E.; LOEBENS, F.; CARVALHO, P.D. Dossiê Amazônia Brasileira. Amazônia indígena: conquistas e desafios. Estud.Av. São Paulo, v.19, n.53, jan./abr., 2005. Disponível em: <http://www.scielo.br/scielo.php?script=sci_arttext\&pid=S010340142005000100015 >. Acesso em: 19 set. 2018.

KLEBIS, A.B.S.O. Concepção de gestão escolar: A Perspectiva dos Documentos Oficiais e dos Programas de Formação Continuada de Diretores de Escola no Estado de São Paulo - 1990/2009. 2010. Tese (Doutorado em Educação) - Universidade Estadual Paulista, Programa de Pós-Graduação da Faculdade de Filosofia e Ciências da Universidade Estadual Paulista "Júlio Mesquita Filho", Campus de Marília. Marília, 2010. Disponível em: <https:// www.marilia.unesp.br/Home/Pos-Graduacao/Educacao/Dissertacoes/klebis_abso_do_ mar.pdf $>$. Acesso em: 2 ago. 2018.

MARCELLINO, N. C. Lazer e educação. Campinas. Papirus, 1987.

MARCÍLIO, M. L. História social da criança abandonada. São Paulo: Hucitec. 1998. Disponível em: <https://pt.slideshare.net/geanipedrosa/histria-social-da-criana-abandonada-autora-maria-luza-marclio >. Acesso em: 23 set. 2017.

MARTINS. W. H. Capricho do absurdo. A morte prematura da República Socialista do Guaporé. SECEL. Porto Velho: Graffporto, 2012.

MENDONÇA, J.G.R. Mulher e criança: ambivalência de dois mundos ditados por especialistas em artigos de revistas destinadas ao grande público entre os anos de 1940 a 1950. 2011. Tese (Doutorado em Educação) - Universidade Estadual Paulista - Unesp. Faculdade de Ciências e Letras, Campus de Araraquara, Araraquara, SP.. Disponível em: < http://portal.fclar.unesp.br/poseduesc/teses/Joao_Guilherme_Rodrigues_Mendonca.pdf >. Acesso em: 20 jul. 2018.

MOURA, G.A.; SOUZA, L.K. Práticas de lazer de idosos institucionalizados. Rev. Movimento, Porto Alegre, v. 19, n. 4, p. 69-93, out./dez. 2013. Disponível em: <http://www.seer. ufrgs.br/Movimento/article/viewFile/36131/27445>. Acesso em: 16 dez. 2015.

NAVARRO, M. S.; PRODÓCIMO, E. Brincar e mediação na escola. Rev. Bras. Ciênc. Esporte, Porto Alegre, v.34, n.3, jul./set., 2012. Disponível em: <http://www.scielo.br/scielo.php?script=sci_arttext\&pid=S010132892012000300008 >. Acesso em: 20 set. 2010. 
PLONER, K. S.; MICHELS, L. R. F.; OLIVEIRA, M. A. M.; STREY, M. N. O significado de envelhecer para homens e mulheres. Disponível em: <http://books.scielo.org/id/ hn3q6/pdf/silveira-9788599662885-14.pdf>. Acesso em: 10 out. 2017.

QUEIROZ, N.L.N.; MACIEL, D.A.; BRANCO, A.U. Brincadeira e desenvolvimento infantil: um olhar sociocultural Construtivista. Paidéia, 2006, v.16, n.34, p.169-179. Disponível em: < http://www.scielo.br/pdf/paideia/v16n34/v16n34a05.pdf>. Acesso em: 15 set. 2018.

SILVA, A. B. Múltiplas faces da infância: Concepções que se constroem no mundo contemporâneo. Trabalho de Conclusão de Curso, apresentado ao Curso de Pedagogia da UEL. Universidade Estadual de Londrina. 2009. Disponível em: <http://www.uel.br/ceca/pedagogia/pages/arquivos/AMANDA\%20BERTOLA\%20DA\%20SILVA\%20.pdf >. Acesso em: 18 set. 2017.

SOUZA, M. C.B.R.A concepção de criança para o enfoque histórico-cultural. 2007.154 f. Tese. (Doutorado) - Universidade Estadual Paulista. Faculdade de Filosofia e Ciências, 2007. Disponível em: <https://repositorio.unesp.br/handle/11449/102252>. Acesso em: 2 set. 2017.

SOUZA, E.S. Sistema de monitoramento e avaliação dos Programas Esporte e Lazer da Cidade e Segundo Tempo do Ministério. Gráfica e editora O Lutador, 2010. Disponível em: <http://portal.esporte.gov.br/arquivos/snee/segundoTempo/sistemaMonitoramentoAvaliacaoProgramasEsporte.pdf $>$. Acesso em: 30 ago. 2018.

WAGLEY, C. Uma comunidade Amazônica: estudo do homem nos trópicos. 3. ed. Belo Horizonte: Itatiaia; São Paulo: Edusp, 1988.

WERNECK, C.L.G.; ISAYAMA, H.F. Lazer, Cultura, indústria cultural e consumo. In: WERNECK, C.L.G; STOPPA, E.A; ISAYAMA, H.F. (Orgs.). Lazer e Mercado. Campinas: Papirus, 2001.

WOLFF. C.S. Mulheres da floresta: Uma história - Alto Juruá, Acre (1890- 1945). São Paulo: Hucitec, 1999. Disponível em: <https://periodicos.ufsc.br/index.php/esbocos/article/view/505/9810>. Acesso em: 3 ago. 2017. 


\section{ADOLESCÊNCIA: MANIFESTAÇÕES DE LAZER NA HISTÓRIA DE VIDA DE IDOSAS DE PORTO VELHO}

Ivete de Aquino Freire

Ramón Núñez Cárdenas

Fernanda Gahu de Oliveira

Walace Henrique Reis Melo

\section{Introdução}

A palavra lazer é muito conhecida no Brasil. Apesar disso, é difícil localizar na literatura atual, um único conceito capaz de abranger todas as multifaces que envolvem esse fenômeno. A literatura atual apresenta inúmeros conceitos e distintas abordagens.

O lazer é uma prática humana e como tal vem acompanhando o homem desde os seus primórdios. Apesar desses aspectos, o fenômeno está condicionado a fatores sociais, econômicos, culturais, políticos religiosos, idade e gênero.

Nos anos de 1930 a 1945, o Brasil vivia uma conjuntura sociopolítica e cultural específica que, de modo direto ou indireto, afetava as práticas de lazer. Sob o Governo de Vargas, a situação era de conflitos políticos e sociais (Skidmore apud Almeida; Gutierrez, 2006). As crises geradas por esses conflitos resultaram em um desconforto das elites que, com medo de uma contrarrevolução da esquerda ou direita, se aliaram a Getúlio para o golpe de Estado em 1937, implantando o Estado Novo.

$\mathrm{Na}$ Era Vargas, foi assegurado o voto feminino, após intensa campanha nacional pelo direito das mulheres ao voto. Nesse período, nasceram as idosas participantes da pesquisa em análise.

Ainda nesse Governo, as atividades esportivas e de lazer, entre outras, eram controladas pelo Departamento de Imprensa e Propaganda (DIP), cujas atribuições eram de supervisionar o turismo, censurar o 
teatro, cinema, atividades esportivas ou recreativas de todos os tipos, bem como os rádios, a literatura social ou política e a imprensa (Gomes apud Almeida; Gutierrez, 2006).

No âmbito do lazer, o foco estava em São Paulo. Nesse período, o lazer foi utilizado como propaganda e controle da população, sendo vinculado a aspectos como a valorização da terra, do homem e das instituições nacionais (Gomes apud Almeida; Gutierrez, 2006).

$\mathrm{Na}$ Amazônia, em especial em Porto Velho, o contexto socioeconômico da época era alentador, apesar de a localidade sofrer com o desastre econômico decorrente da crise internacional da comercialização da borracha. No Governo de Vargas, as projeções acenavam para uma fase de transição: de uma cidade com péssimas perspectivas de desenvolvimento para ser uma localidade inserida nas políticas elaboradas para todo o Brasil, especialmente para a região do Guaporé (Gorayeb, 2015).

A nova tentativa de investir na comercialização do látex na Amazônia, que deu origem ao denominado $2^{\circ}$ Ciclo da Borracha ou fase de sobrevida (1942 a 1945), se dava pelo investimento de capital norte-americano (D'Agostini et al. apud Nascimento, 2010). Durante a segunda Guerra Mundial (1939-1945), os aliados do Brasil precisavam urgentemente de borracha e impulsionaram o comércio da Amazônia através de investimentos na produção do látex na Era Vargas (D’Agostini et al. apud Nascimento, 2010; Gorayeb, 2015).

Nesse período, a população de Porto Velho vivia entre os resquícios de uma infraestrutura herdada do período áureo da extração e comercialização da borracha, ocorrido entre 1879 a 1912. Vivia a decadência, registrada pela queda na receita dos estados, alto índice de desemprego, êxodo rural e urbano, sobrados e mansões completamente abandonados e, principalmente, falta de expectativas em relação ao futuro (Carneiro, 2017). Com os investimentos que subsidiaram o $2^{\circ}$ Ciclo da Borracha, criou-se uma expectativa positiva da Amazônia: novamente ganhar importância e voltar ao cenário nacional e internacional. Foi nesse contexto de esperança (precisamente em 1940) que as terras de Porto Velho, que integravam o município do Estado do Amazonas, foram instituídas como município 
do Território Federal do Guaporé (Gorayeb, 2015). Entretanto, foi curto o período de esperança. Durou menos de cinco anos a "re-ascensão" da comercialização internacional do látex da Amazônia.

Considerando essa realidade socioeconômica apresentada brevemente, neste capítulo serão relatadas as memórias das idosas referentes às suas práticas de lazer no período em que eram pré-adolescentes e adolescentes. Para tanto, identifica-se o contexto socioeconômico e cultural nessa etapa da vida; demonstram-se as características das vivências de lazer das mesmas; e descrevem-se os espaços de lazer bem como os materiais e equipamentos utilizados.

\section{Procedimentos metodológicos no marco da trajetória de vida}

Os detalhamentos metodológicos da pesquisa sobre o lazer das idosas nas fases de pré-adolescência e adolescência estão inseridos no Capítulo 2 desta obra. Aqui, ressalta-se que a pesquisa foi realizada com nove mulheres acima de 79 anos, integrantes de dois grupos de convivência: Pioneiras de Rondônia e Grupo de Trabalho TSI do SESC/Rondônia.

Considerando as datas de nascimento, ponderou-se que as fases de pré-adolescência e adolescência das entrevistadas estivessem entre 1940 a 1956, conforme quantitativo de idosas e seus respectivos anos de nascimento, especificado na Figura 1.

Figura 1 - Demonstrativo das variações de ano em que as idosas se encontravam nas etapas de pré-adolescência e adolescência.

\begin{tabular}{|l|c|c|c|c|c|}
\hline $\begin{array}{l}\text { Ano de } \\
\text { Nascimento }\end{array}$ & 1928 & 1930 & 1931 & 1934 & 1937 \\
\hline $\begin{array}{l}\text { Quantitativo de } \\
\text { Idosas }\end{array}$ & 1 & 3 & 1 & 2 & 2 \\
\hline $\begin{array}{l}\text { Pré-adolescência: } \\
\text { até os 19 anos }\end{array}$ & $1940-1947$ & $1942-1949$ & $1943-1950$ & $1946-1953$ & $1949-1956$ \\
\hline
\end{tabular}

Aqui se reconhece que a fase da adolescência não se restringe à esfera física, mas varia segundo diversos aspectos, conforme lembra Blefari (2003). Pela carência de estudos desse tema, utilizou-se para delimitação da adolescência das entrevistadas, além do parâmetro biológico orientado 
pela idade cronológica, as suas falas quando se autoavaliavam na fase de adolescente.

A trajetória lúdica na infância dessas mulheres foi marcada pelas seguintes características:

- As vivências lúdicas eram restritas, decorrentes, sobretudo, da falta de tempo, que prioritariamente era ocupado com trabalhos que iam desde cuidados com o roçado a trabalhos domésticos e serviços de babá;

- Na carência de brinquedos industrializados, os recursos da natureza davam asas à imaginação infantil, e tais experiências lúdicas eram vividas com grande intensidade e satisfação. Desse modo, folhas de palmeiras, barro, galhos de cacaueiro, sabugo de milho, cachos de açaí, a borracha da seringueira em estado bruto e ossos de animais se apresentaram como importantes aspectos da bagagem sociocultural do universo lúdico das idosas na infância e se tornavam artefatos para confecção de brinquedos. Também se visualizavam as bonecas de pano confeccionadas no próprio lar, além de bolas, cordas e petecas.

- As manifestações de lazer se ofuscavam mediante as experiências socioculturais mais amplas, construídas com base no trabalho, como principal referência cotidiana e único caminho para a sobrevivência.

\section{As memórias sobre o lazer na adolescência}

Somente 2 (duas) idosas não tiveram acesso à escola. Entretanto, apenas uma (Tainá) não teve seus estudos interrompidos ainda na infância. Tainá foi a única idosa identificada que teve oportunidade de continuar seus estudos até obter uma profissão. As demais ou não frequentaram a escola ou tiveram seus estudos cessados, conforme se observa nos fragmentos das entrevistas apresentados a continuação. 
Fui estudar no Colégio Maria Auxiliadora e eu já tinha um quarto ano primário, mas naquela época tinha [...] não. Eu tinha o quinto ano primário. Depois do quinto ano se fazia um preparatório para poder começar aquele normal [...] regional. Mas eu não fiz o regional porque quando eu terminei o $5^{\circ}$ ano chegou o ginásio pra Porto Velho que era do Território do Guaporé. E eu cursei quatro anos de ginásio. Depois cursei mais dois anos intensivos do Curso Pedagógico, pra formação de professor (Tainá).

Frequentei escola. Então pra gente estudá um estudo melhor era no Humaitá (Município do Estado do Amazonas), que era das Freiras [...]. Ai estudei mais um pouquinho com as freira, mas não foi muito. A minhas [Interrompeu]. Estudando, no colégio, estudava no colégio Maria auxiliadora. [...]. Ahb [Voz aguda, gaguejando]. Eu estudava mas... eu estudei muito pouco lá (Janaína).

Estudei nada, nunca me botaram, nunca pisei na porta de uma escola (Jurema).

$\mathrm{Na}$ época em que as idosas eram adolescentes, o contexto social, político e econômico brasileiro era de aproximadamente duas décadas de pós-revolução de 1930 e instituição do denominado Estado Novo, constituído após diversos conflitos políticos e sociais, principalmente entre a esquerda (comunista) e a direita (fascista). Com o Golpe de Estado e o apoio necessário para desenvolver o programa de Governo, Vargas inicia o processo de substituição das importações, com o investimento na indústria local e, também, o controle do Estado nas indústrias de base, possibilitando investimentos em setores como transporte, construção civil, siderurgia, petróleo e bens de produção (Skidmore apud Almeida; Gutierrez, 2006).

Nessa conjuntura, constatam-se no Brasil avanços tecnológicos significativos. Cria-se uma infraestrutura para a produção cultural com investimento privado. Exemplo disso é o Teatro Brasileiro de Comédia e os estúdios cinematográficos (Bernardet apud Almeida; Gutierrez, 2006). Foi criada, também, uma grande composição de mídia de massa, base para formação de uma estrutura ideológica política, através do Departamento de Imprensa e Propaganda, e o início do Cinejornal, sedimentando o populismo por todo o território nacional (Capelato apud Almeida; Gutierrez, 2006). 
Entretanto, na época da pré-adolescência e adolescência, a situação de vida das idosas entrevistadas parecia não sofrer nenhum impacto social, político e econômico do contexto nacional; semelhava-se padecer as penúrias do esquecimento por parte do poder público. E as então adolescentes, por sua vez, também pareciam ignorar tais acontecimentos.

Ninguém sabia nada [Das coisas que aconteciam fora de Porto Velho, no resto do Brasil e no mundo]. Ninguém sabia. Ai, depois, quando a gente vinha saber, quando sabia. Que quem tinha rádio, quem tinha rádio sa sabia pelo Jornal Nacional, pelo Jornal Nacional. O jornal Nacional que fala que até hoje inda tem. Aquele que faz tam tam tam tam tam [Sonorizando] e ai apresenta o Jornal Nacional. A hora do Brasil, pelo rádio, era 6 horas. Hummm! [Tomando água] (Yara).

As idosas relatam que o contato com o mundo externo à cidade de Porto Velho ou da região era precário. Dava-se através de rádio ou de cartas, como se pode observar na fala de Yara

No período da adolescência das entrevistadas, um aspecto político importante ocorreu na localidade. Em 1956, a cidade de Porto Velho se torna município do Território Federal de Rondônia (Gorayeb, 2015). Esse tipo de acontecimento político foi manifestado apenas por uma depoente, conforme ilustrado no capítulo seguinte.

Na região Amazônica, vivia-se a fase pós-segundo Ciclo da Borracha, a partir de 1945 (D’Agostini et al., 2013). Portanto, as idosas-adolescentes viveram os primeiros anos de fracasso da segunda tentativa de retomar a atração de riqueza para a região, via exploração e comercialização do látex. A expansão da colonização, a continuidade das transformações culturais e sociais e o impulso ao crescimento das cidades Amazônicas não se repetiram. As cidades de Manaus e Belém, que eram na época consideradas as cidades brasileiras mais desenvolvidas e mais prósperas do mundo, estagnaram (Souza, 2017; Portal da Amazônia, 2017). Citam os historiadores que, no período correspondente a 1890 a 1920, cidades como Manaus, Porto Velho e Belém contavam com infraestrutura como eletricidade, sistema de água encanada e esgotos, museus e cinemas. 
Em Porto Velho, destaca-se como grande investimento da época do $1^{\circ}$ Ciclo de exploração do látex, a construção da Estrada de Ferro Madeira Mamoré, finalizada em 1912. Ao redor do local dessa construção se deu o povoamento de Porto Velho, marcando a localidade como centro da cidade.

Entretanto, nessa paragem, igualmente às demais capitais da Amazônia, as ações do Governo se limitavam aos centros das cidades, dando pouca importância às periferias e ao interior dos Estados (Leandro, 2014; Souza, 2017; Portal da Amazônia, 2017). Crítica realizada por Leandro (2014) destaca as contradições dos benefícios obtidos no apogeu da exploração do látex e o declínio na sua comercialização. De acordo com o autor, o progresso da belle époque Amazônica se realizava apenas nas aparências sociais, porque o sistema produtivo continuava o mesmo do período colonial.

Narra Yara que tanto a chegada de notícias quanto o contato com pessoas que residiam fora de Porto Velho (e em outros Estados) era difícil e demorado. A situação de isolamento das outras localidades do país, mesmo entre as cidades da mesma região, fazia parte da realidade das pessoas que não tinham acesso aos meios de comunicação. O que não ocorria com os funcionários da Estrada de Ferro Madeira Mamoré e os grandes empresários da borracha, que tinham acesso ao Serviço de radiocomunicações, além de viagens constantes no famoso navio Lobo D’Almada. Martins (2012) narra sua aventura amorosa com uma adolescente que estudava em Manaus e passava as férias no seringal com a família. Também comenta o autor os seus diálogos com uma amiga, destacando como, no sudeste brasileiro, o existencialismo de Sartre e Simone de Beauvoir estava no discurso dos universitários da época. Destaca o autor que o momento era de amadurecimento cultural dos portovelhenses. A que categoria de portovelhenses estaria fazendo referência o autor? Esse fato parece distante da realidade das idosas-adolescentes.

Ainda relativo a como as notícias chegavam de modo diferente entre adolescentes pobres e aqueles com maior poder aquisitivo, conta Martins (2012) que um seringalista de Porto Velho mandou sua filha, apaixonada por um rapaz pobre, para arrefecer os ânimos amorosos em Paris. 
No contexto das mulheres depoentes, o isolamento dos moradores das periferias se ampliava quando as comparações se referiam aos grandes centros culturais do Brasil e do resto do mundo. Além do afastamento geográfico dos grandes centros do país, existia também um isolamento de informações.

O rádio não, não, num tinha, depois, depois, foi que apareceu o rádio aqui pequeno, né? que mal dava pra, pra funcionar. Ab! As notícias era por car, mandava carta. Era por carta. Daqui a um mês, a quinze dias. Telefone também não tinha não [...]. Era por meio de carta. Por exemplo, o navio ia pra, pra Manaus aí você escrevia e mandava pelo comandante. Lá ele entregava e ia atrás [...]. Ninguém sabia do que acontecia fora daqui (Yara).

Nenhuma das idosas, quando adolescente, residia no centro da cidade de Porto Velho, localidade onde se concentravam os benefícios de infraestrutura, resultado do apogeu econômico propiciado pelo período da exploração e comercialização da borracha. Portanto, elas parecem não ter sido afetadas com o fim dos períodos áureos de comercialização da borracha.

Apesar da precariedade ou simplicidade do local de moradia, em alguns momentos observam-se lembranças agradáveis que algumas depoentes recordam com carinho.

Era. Tinha dezesseis casas lá, onde morava. Lá era bonito, assim. Era bonito, assim. Tinha muito of reguês. Tinha um animal que carregava as coisas, assim, negócio de borracha e castanha. Tinha aquelas Toyota que carregava aqueles saco de castanha, café (Anahi).

Apesar das boas lembranças, as idosas também narram a precariedade de infraestrutura das moradias. Destacam as dificuldades para o acesso à água, problema que se manifestava em suas vidas desde a infância.

Isso aqui era mata. Andava assim por meio de (Pensando) daquele caminzim [Caminho estreito] de roça... Ali em frente a igreja era um chafariz. Era a maior briga para consegui água. Tem que fazer madrugada pra botar latinha uma atrás da outra pra pegar um pouco d'água. Tinha água não [...] 
É... [Pensando]. Tinha que botar latinha pra encher pra trazer. Tinha! pouca mas tinha (Janaína).

Na época ainda não tinha luz elétrica não. A água era água de poço. Depois foi que veio a água encanada e a luz elétrica. Veio tudo de pouco. (Yara).

Olha, casa mesmo só tinha uma deste lado que era uma casa de taipa aqui neste outro terreno aqui [Sinaliza com a mão]. E tinha umas duas casa ali, que na época todas eram cobertas com palha [...]. Não, aqui do lado da rua e aqui do lado não tinha nada, só mato [...]. Olha, em Porto Velho existia, mas aqui não tinha nem energia e nem água encanada (Tainá).

Tainá explica que, em Porto Velho, tinha água encanada e energia, mas, na localidade em que morava (No caso, na periferia da cidade), as residências não dispunham desse serviço. A fala da depoente deixa implícito que morar na periferia não significava para ela morar em Porto Velho, quando diz que "em Porto Velho tinha energia e água, mas o local que morava não usufruía desse benefício". Também chama a atenção que mesmo com o progresso conquistado no centro da cidade pelo período áureo da extração e comercialização do látex, ainda era possível a existência de residências de taipa nas periferias da cidade. A precariedade desse tipo de moradia não é mais visualizada nos dias atuais na cidade de Porto Velho, mesmo das famílias mais pobres.

Como não poderia ser diferente, o lazer das idosas, durante a adolescência, estava condicionado à classe social e à cultura dominante em que estavam imersas. A precariedade da infraestrutura de moradia e a pouca ou nenhuma influência da política nacional para o setor sinaliza a trajetória de lazer dessas mulheres.

No âmbito nacional, as atividades esportivas e de lazer, entre outras, eram controladas pelo Departamento de Imprensa e Propaganda. As atribuições desse departamento eram de supervisão e censura bem como de estimular ações (tais como produção de filmes nacionais) educativas e nacionalistas para benefício do Governo (Gomes apud Almeida; Gutierrez, 2006). Desse modo, as idosas-adolescentes viveram um período de resquícios dessa política. 
No período de 1935 a 1938, em São Paulo foram criados/oficializados quatro Parques Infantis. Posteriormente, outros parques foram projetados e instalados em bairros operários e industriais da capital, marcados pela pobreza, próximos a escolas públicas ou às fábricas, enfim, em locais em que pudessem ser socialmente úteis (Vieira, 2004). Mas, evidentemente, tais políticas não chegavam aos rincões mais distantes da Amazônia. Ironicamente, a literatura atual (Mendonça; Silva; Oliveira; Dantas, 2009) fala da necessidade de as políticas sociais brasileiras, dentre elas as do lazer, ultrapassarem a lógica paternalista e assistencialista que ainda caracteriza as administrações públicas do país. Pela fala das depoentes, nenhum tipo de política pública chegava até essa população, nem mesmo aquelas paternalistas e assistencialistas, duramente criticadas na atualidade. Com base no que dizem Fernandes e Coelho (2009) e considerando os fatores culturais, econômicos, políticos e sociais aos quais eram submetidas essas jovens meninas, pode-se dizer que elas viviam em condições de vulnerabilidade social, gerada pela pobreza e pela exclusão de benefícios sociais.

Narra Martins (2012) que o contexto político nacional era o da promulgação da Constituição Federal de 1946. Na primeira campanha política da história brasileira, o Coronel Aluízio Ferreira, amigo de Vargas, elegeu-se Deputado Federal do então Território Federal do Guaporé. Somente a partir da década de 1950, os movimentos da esquerda civil começaram a tomar vulto através do líder Renato Medeiros. Destaca Martins (2012) que, naquela época, apenas "meia dúzia" de pessoas sabia distinguir o significado de "direita" e "esquerda" no campo da política. Na realidade das idosas, como a maioria dedicava-se quase que ininterruptamente ao trabalho, e sem acesso à formação e informação, provavelmente se inseriam no grupo que não sabia elaborar tal distinção.

No campo do lazer, os espaços eram restritos. Não foi citado, por exemplo, por parte das idosas, a existência de parques. Na localidade, a única praça encontrada no centro da cidade era um importante ponto de frequência das adolescentes. Próximo à praça, encontrava-se o cinema, que também era outro espaço destinado a encontros. 
Tinha, tinha praça. A praça [pensando] lá, lá embaixo, ali, perto. Lá, lá embaixo, é lá do centro, sim, já tinha, já tinha aquela praça. Era a única praça que tínhamos era aquela. [...]. Todo domingo, todo domingo, aí tinha o cinema Brasil o pessoal ia pro cinema quando saia ai depois veio o Resk, o cinema grande, de potência, né? Ai vinha e ai tinha o, o, e tinha de tarde e a noite. Mas de noite quando saía inda iam passear na praça [...] (Yara).

$\mathrm{Na}$ localidade, a praça e o cinema eram os espaços institucionalizados de lazer; entretanto, se situavam na zona central da cidade, fora e distante dos ambientes residenciais das depoentes.

Yara comenta que "o pessoal ia pro cinema", deixando subentendido que ela não ia. Provavelmente porque esse tipo de lazer indicava pagamento; e o poder aquisitivo dela não permitia que usufruísse desse divertimento. Já nessa época observa-se, assim como na atualidade, ainda que em menor proporção, a oferta de lazer como mercadoria. $\mathrm{Na}$ "não frequência" aos cinemas e aos clubes, vê-se, claramente, a restrição de acesso aos serviços de lazer privatizados quando comparados com aqueles de caráter público.

Conforme será explicado mais adiante, Yara tinha algumas restrições ao lazer. O que denominamos restrições é nomeado por Marcellino (1983) como condicionantes de lazer, a exemplo do poder aquisitivo.

$\mathrm{Na}$ realidade das idosas, quando pré-adolescentes e adolescentes, embora os espaços fossem limitados, os tipos de lazer se manifestavam um pouco mais diversificados quando comparados com a infância e a meninice. Este fato pode ser observado nas falas das depoentes.

[...] Lá era atrás de bicho na praia, viaja. Gostava muito de fazer viagem, fazê frete de Humaitá, pra Amazonas, Manicoré. [...]. Bola também, festinha também. [...]. Brincava de roda, num tem? [...]. Na casa de amigos, na casa de parentes, né? A gente ia pra, tinha lá o Caiari [Bairro no Centro da cidade cujas moradias foram construídas para funcionários de altos cargos da Estrada de Ferro Madeira Mamoré], tinha festejo de São Sebastião e ai se ajuntava, fazia aquele [Não conclui] Ia na casa do seu Lamarão que era num, num, lá em... [Tentando lembrar] dos Lamarão. Tinha os Miriti que era o seu Armando Beleza. Esse negócio destas festinha 
a gente ia. A mamãe levava a gente, sabe? Não podia, adolescente queria tá andando também (Taynara).

Era de roda. Brincadeira de roda. A gente se juntava aquela turma de moças ai ia brincar de roda. De noite a gente se juntava e ia brincar (Apuana). Era, brincava coisa de menino mesmo de correr [...] no Humaitá que era tempo do festejo de Nossa Senhora que ela e a gente ia para lá, o festejo [...]. Lá tinha campo de futebol pra os time jogá e lá era muito animado (Anahi). [...] festa na roça, né? Fazia fogueira essas coisas, né? É. São João na roça [...] festa de fim de ano essas coisas, né? Às vezes quando a chuva deixa sempre fazem na rua [...] brincava de bola, de roda [...] brincava de boneca [...] Jogá bola [...]. Só ai mermo nessa praça mermo que ainda tem aí [...] Aluizio Ferreira [...]. As vezes o Martinesin [Na região denomina-se matinê a oferta de cinema no horário da tarde] que tinha naquele tempo que tinha cinema, né? [...]. Agora que não tem mar nem cinema. Dentro do colégio mermo [...]. No parquezinho lá pra brincar (Janaina).

Olha na época tinha cinema, tinha o Cine Brasil. Tinha a Praça Marechal Rondon que era o chique dos domingos e o povo ia passear na praça. Ou aqui em casa ou nas casas das amigas. A gente se reunia pra conversar, pra dançar, pra brincar [...]. De bola, de peteca (Tainá).

Eu tinha um bocado do cole. Ab! a Nadir [O nome de uma das amigas], lá dôo SESC iì estudei com ela. Nada mas. Aquelas rodinha de cunversinha, cunversando (Janaina).

Apesar da variedade de lazer das idosas quando adolescentes, pouco se observa a presença de práticas criativas e inovadores. Igualmente na infância, algumas delas sofriam fortes restrições para essa prática.

Nas falas de Taynara (atrás de bicho na praia), Anahi (brincava de correr) e Janaína (participação em festa na roça), se observam rasgos de possibilidade de práticas de lazer estimuladoras da criatividade. Entretanto, ao estabelecer uma ponte entre essas experiências e os aspectos teóricos sobre o tema, parece que essas atividades não alcançavam os conceitos atuais. Segundo Gomes, Pinheiro e Lacerda (2010), o lazer representa uma possibilidade de mobilização e engajamento político, facilita a criação de redes de sociabilidade e estimula a reflexão sobre nossa sociedade. 
Quando se fala em "ser adolescente", mulher e pobre, na Amazônia, cuja cultura de referência era marcadamente diferenciada das demais regiões do país, esses ideais são ainda mais distantes. Anahi, por exemplo, se casou muito jovem e a fase de adolescência se mistura com as responsabilidades da fase adulta.

Eu me casei nova minha filha. Casei com dezesseis anos (Anahi).

Já na fala de Taynara, observa-se total submissão às normas da família, que retratavam as regras sociais da época e da localidade.

De mocinha, a gente humm [Tentando lembrar]. Se a gente saisse pra passear com os vizinhos alguma coisa, né? a minha mãe dizia eu vou cuspi aqui, se passar da hora vocês vão apanhar [Risos] (Taynara).

Além dos aspectos culturais, as restrições ao lazer também decorriam da baixa condição econômica das adolescentes. Os trabalhos domésticos aos quais eram submetidas tinham um caráter educativo, mas, acima de tudo, era uma necessidade; exigência do ambiente doméstico e/ou familiar.

Minha filha, meu lazer era trabalhar. Na época era trabalhar. Eu não sabia o que era lazer. Sabia não. [...] arrumá casa, lavá, passá, criá menino (Yara).

Igualmente na infância, constata-se limitação nas atividades de lazer das idosas no período da adolescência, seja pelo pouco tempo que sobrava da jornada de trabalho a qual eram submetidas, seja pelo rigor educacional. Em um ou em ambos os casos, o divertimento ficava sempre em segundo plano. Destaca-se, como exceção o caso de Taynara, que visualizava labores piores do que aqueles do âmbito doméstico; o trabalho na roça, por exemplo.

Tudo que tivesse de fazer eu fazia. Só não gostava de ir para roça. Me chamavam até de Raimundo Seando. Só queria tá no bem bom [Risos] (Taynara). 
De modo geral, o trabalho de algumas idosas extrapolava o âmbito familiar. No caso de Jurema, que foi morar com uma família, trabalhava para sua subsistência, apesar de não ter qualquer remuneração. Trabalhava em troca de casa, comida e vestuário.

A narrativa das idosas indica que, na adolescência delas, era considerado natural que exercessem papéis de adultos. Utilizando o termo empregado por Birman (2008): trata-se de uma cartografia do trabalho doméstico diferente da atual. A literatura sinaliza que as responsabilidades atribuídas ao adolescente, no âmbito familiar, se transformaram radicalmente nas últimas décadas.

A forte presença da modalidade do trabalho doméstico entre as adolescentes do período estudado não tem fundamento em um processo natural, mas cultural, interligado à precarização das condições sociais e econômicas das famílias pobres.

Considerando-se que a maioria das mulheres depoentes não teve acesso a níveis de escolaridade profissionalizante, inclusive tiveram os estudos interrompidos precocemente, e que, por outro lado, sofriam forte influência para a prática de trabalhos domésticos, constata-se que havia o preparo de toda uma geração de mulheres pobres para se dedicar especialmente aos labores do lar.

Não! Eu fui trabalhá, ajudá a fazê as coisas lá com ela. Não me pagava, né? Me davam o que precisava, né? Roupa, sapato, remédio, né? Essas coisas. Ganhava dinheiro não (Jurema).

Ai o juiz me mandou pra caso do doutô Oscar. O Oscar foi embora e ai o juiz me mandou pra casa do doutô Ananias. Tinha três crianças. Eu fazia tudo. Uma vez eu inventei de estudar de noite mais desisti, porque quando eu chegava na aula, já estavam passando a tarefa para casa (Yara).

$\mathrm{Na}$ cultura da época, ainda que sem amparo legal, era comum a "adoção" de uma criança ou adolescente pobre por uma família mais abastada, conforme narram Jurema e Yara. As precárias condições socioeconômicas de uns e a fartura de outros, aliadas à ausência de políticas públicas efetivas para as crianças e adolescentes de famílias pobres, 
resultavam no que se denomina atualmente de "exploração do trabalho infantil”. Segundo Cavalcante (2011), a exploração do trabalho infantil é condição de exploração de crianças e adolescentes, em prejuízo à saúde e ao desenvolvimento delas, assim como o comprometimento do exercício do direito de brincar e estudar.

$\mathrm{Na}$ época de infância e adolescência das entrevistadas, já havia sido efetivado no Brasil o primeiro instrumento de proteção à criança e ao adolescente, ocorrido 1927. O denominado Código de Menores proibia, em todo Território Republicano, o trabalho em geral para os menores de 12 anos e o trabalho noturno para os menores de 18 anos. Posteriormente, durante a Era Vargas, em 1932, essa idade foi ampliada para 14 anos, e a idade para trabalhar durante o período noturno foi reduzida para os menores de 16 anos (Barros, 2011). Enfim, o final da década de 1920 e o início da década de 1930 constituem um marco na criação de leis sociais trabalhistas que instituem, além da determinação das idades mínimas para o trabalho, também a diminuição da jornada de trabalho, fins de semana e férias (Bruhns, 1997). Após a criação do Código de Menores, outros instrumentos de proteção foram implementados para resguardar as crianças e os adolescentes com relação ao trabalho. Alguns com avanços e outros com retrocesso (Barros, 2011; Custódio; Veronese, 2013). Entretanto, somente com o Estatuto da Criança e do Adolescente (ECA), de 1990, consolidou-se os direitos da Criança e do Adolescente no Brasil.

O modelo de adoção apresentado pelas depoentes, apesar de contar aspectos positivos, tais como a garantia de sobrevivência através de moradia, alimentação e vestuário e, em alguma medida, o aporte educativo, tem o seu lado cruel. Conforme cita Queiroz (2014), orientada por vários autores, as tarefas domésticas excessivas impedem a frequência escolar ou o rendimento acadêmico satisfatório da criança e do adolescente. Segundo Sabóia (apud Queiroz, 2014), em muitos casos, esses afazeres domésticos realizados predominantemente por meninas são tão árduos que as impedem de estudar. Este último apontamento fez parte da realidade na vida de algumas entrevistadas, a exemplo de Yara. 
Embora nenhuma mulher tenha falado explicitamente da condição socioeconômica de suas famílias, essas características perpassam nas suas falas, mesmo que não se tenha perguntado sobre o tema. Tal condicionante afetava toda a rotina das adolescentes, e no lazer não poderia ser diferente.

Na minha adolescência já tinha. Já tinha esporte, só que eu não... não chegava até ele (Yara).

O verbo "chegar", utilizado por Yara, demonstra a consciência que ela tem atualmente sobre as dificuldades de acesso, que se ostentava na época, a determinados tipos de lazer, em função do baixo poder aquisitivo que possuía. Com base em uma publicação de Bruhns, de 1997, sobre a participação da mulher na esfera do lazer (em especial em atividades de esporte), pode-se inferir que, nas décadas anteriores a essa publicação, eram ainda mais acentuados os desafios. Esses desafios se manifestam em níveis diferentes, considerando fatores culturais e socioeconômicos. Portanto, se confirma a interpretação de Bruhns (1997), quando pensamos em mulheres pobres e residentes em uma região inóspita e isolada geograficamente dos grandes centros urbanos do Brasil, a exemplo de Rondônia, no coração da Amazônia.

Conforme demonstra Yara no fragmento a seguir, essa limitação de acessibilidade extrapolava o âmbito do lazer, penetrando pelas distintas esferas sociais.

As outras moças? Ah, elas, elas estudavam. Ela a profissão delas era no momento era estudar. Quem podiam, os pais podiam, estudavam, né? (Yara).

Constata-se, portanto, que a cultura, juntamente com os aspectos socioeconômicos, se manifestava mais do que fatores condicionantes do lazer das adolescentes; caracterizavam-se como fatores limitantes de ascensão social.

Apesar de as idosas não disfrutarem de todas as possibilidades de lazer existentes a época de adolescentes, fragmentos de texto mostram que elas tinham conhecimento do que existia, embora não tivessem acesso. 
Destacam-se, na narrativa de algumas delas, as condições de desigualdades no usufruto de algumas atividades de lazer.

Elas iam passear (as moças), elas iam pra banho, iam pra banho, elas iam pro cinema, elas iam pra festa, porque, né? Nessa época, tinha, tinha o Nacional o Clube Nacional, que é ali aonde é o [Clube atual da cidade]. Ali era o Clube Nacional que era um clube de elite, né? o Danúbio Azul era de má de baixa rendas, e ficava lá no Cai N’agua (Yara).

[...] as mães não soltava as filha, principalmente mulher, assim pra tá soltas na rua e na casa dos vizinhos. Tinha horário da gente brincar [...]. Quando chegava eu tinha o almoço, já tinha alguma coisa para fazer, né? vai ajudar as mãe [...]. Já tinha coisa de paquerar e a mãe não soltava muito (Anahi). Ela não deixava a gente brincar. Ficava lá com ela (Iracema)

A mãe costurava muito, ai viu, né? Às vezes ela não deixava a gente brincar pra ajudar ela ali, né? (Janaína).

Olha eu acho que nesta época a gente nem tinha tempo de brincar que, que não tinha vizinhos, né? É só estudava e vinha pra casa, ajudava fazer os serviço de casa (Tainá).

Resguardadas algumas diferenças, na fala de Tainá constatam-se vestígios de uma prática de lazer atrelada ao que se denomina atualmente de abordagem econômica dos estudos do lazer, conforme explorado no Capítulo 1 desta obra. Tais vestígios se apresentam na medida em que o lazer, na perspectiva econômica, é visto como uma prática oposta ao trabalho ou como o momento do não trabalho. Nota-se, na narrativa das depoentes, a justificativa para a ausência de lazer pelo excesso de atividades laborais. Portanto, destaca-se aí a presença de lazer como não trabalho; como atividade de tempo livre, conceito atualmente ultrapassado, idêntico ao destacado no Capítulo 1 deste livro.

A fala das idosas encaminha para uma interpretação de que a adolescência parecia não ocorrer como uma idade específica da existência humana, com todas as características do que se entende atualmente como adolescência. Neste contexto, há que lembrar que as adolescentes eram subordinadas a regras sociais específicas da época e da localidade, 
destoando de outros períodos mais adiante. Recorda Motta (2010) que a situação da adolescência do início do século XXI já se distancia da posição da adolescência do início do século XX. Na década de 60, por exemplo, segundo a autora, se inicia na sociedade um processo de idealização da adolescência, entendendo-a como um período da existência em que a ordem é aproveitar a vida livremente. Pelo dizer de Motta (2010), pode-se afirmar que, antes dessa década, os ideais de liberdade e de autonomia do adolescente eram praticamente inexistentes, principalmente em regiões distantes geograficamente (como a Amazônia, por exemplo) e com acesso limitado à comunicação com os centros mais avançados do país. Por outro lado, na cultura da época, independente do julgamento de que esses valores seriam ideais ou não, eram fortes as referências que contribuíam em direção a uma travessia da adolescência como uma passagem menos conflitiva do que a atual. Daí a compreensão da narrativa das idosas não contemplar aspectos relacionados a comportamentos com rasgos de revolta, trauma, impulsividade, crises existenciais, condutas contraditórias ou reivindicatórias comumente observadas na adolescência. Pode-se constatar a tranquilidade com que Yara afirma que as "As moças frequentavam os balneários, o cinema e as festas", deixando nas entrelinhas que ela não frequentava esses locais. No discurso de Yara, vislumbra-se o cultural tomado como natural e universal, uma vez que os motivos dessa não acessibilidade decorriam de uma rotina dura de trabalhos domésticos, além de atuar como babá de três crianças.

Igualmente na infância das mulheres depoentes, parece que essa etapa da vida (adolescência) não havia sido constituída socialmente. De certa forma, Birman (2008) faz referência a essa questão, quando afirma que as crianças e os adolescentes de outrora se caracterizavam em geral pela maior segurança e pela expansão do "eu" em bases mais sólidas. Também se visualizava ausência de perturbações psíquicas e comportamentos antissociais, dentre outros, que caracterizam as diversas formas de mal-estar hoje.

As idosas mencionam seu cotidiano de trabalho e ausência ou precariedade de lazer, durante a adolescência, como um processo natural incompatível com o estilo adolescente de existência atualmente difundido, 
conforme termo utilizado por Birman (2008). A ausência de compreensão e definição da adolescência prevaleceu até o século XVII, conforme afirma o autor. Segundo Birman (2008), o conceito de adolescência, juntamente com o de infância, aconteceu somente na passagem do século XVIII para o XIX, portanto, esse conceito já existia, pelo menos do ponto de vista teórico, durante a adolescência das idosas.

Com as devidas diferenças de época, os raros momentos de lazer das idosas eram compartilhados seguindo o mesmo modelo da atualidade, entre a família consanguínea, os amigos ou as famílias com as quais residiam.

Uma pesquisa realizada por Possamai, Gastal e Negrine (2009), na Serra Gaúcha, com idosos, resgatou a memória das experiências deles em relação ao lazer e às viagens quando eram jovens. Os idosos narraram que as dificuldades eram inúmeras e variavam desde os deslocamentos em veículos impróprios, até a precariedade das estradas, impossibilidade de aquisição de alimentos no trajeto, e falta total de conforto e segurança. Entretanto, tais vivências de lazer estão entre as boas lembranças como momentos inesquecíveis de diversão. Conforme citam Gomes, Pinheiro e Lacerda (2010), o imaginário, alimentado por essas mulheres em relação ao lazer e às viagens que desfrutaram, é tão forte que nele se destaca o prazer, em que pesem todas as dificuldades vivenciadas para o usufruto dessas práticas. Tal motivação e prazer não são vislumbrados nas memórias das idosas da Amazônia, cujas falas são marcadas majoritariamente por momentos difíceis.

Era dificil. Era difícil porque assim, os menino era pequeno [As crianças que cuidava]. Mas ali, na, como quem vai, a gente vai pro aeroporto, tem naquela passagem que tem chamava os tanque. Então aquilo ali era limpo, aquilo ali era um banho excelente e era aonde a gente ia. E ai eu ia. Os menino, os menino da família e mais alguns vizinho. Ali os tanque. [...] ia, ai iam mas eu tinha que tomar de conta [Das crianças], né? [Risos]. É, é, é mas assim mesmo eu me divertia. Ou tinha outro banho também, que é lá no km 10, que é que é lá era militar mas eles abriram abriu mão, né? Então a gente ia pra lá aos domingos. De vez em quando a gente ia pra lá. [...]. Para dançar, ia com minhas amiga, minhas colega, que hoje em dia umas já se foram [Voz contida, demonstrando pesar] (Yara). 
Viajava no motor do meu padastro (Taynara).

Tinha, mas tinhas as colega. Mas era que ia lá em casa, mas era conhecida dela (Frequentavam a casa as conhecidas da senhora que a depoente chama de Turca). Ai ficavam lá (Iracema).

A minha mãe ia comigoé, minha mãe não deixava eu andar só [Risos] [...] Minhas colegas sempre a gente se reunia (Tainá).

Tudo o que foi dito pelas entrevistadas, em especial as atitudes de obediência, está em consonância com o registro simbólico da época que, por sua vez, tem íntima relação com o que se passava nos registros econômico, social e político daquele momento.

Nesse contexto, o lazer e o cotidiano em geral vivido pelas mulheres estão vinculados aos aspectos sociais e geográficos patentes no cenário da região Amazônica, de Rondônia e em especial da cidade de Porto Velho. Trata-se de uma realidade diferente da realidade dos grandes centros urbanos do Brasil. Definitivamente, o lazer não era um direito incondicional a todos, independentemente da classe social, religião, idade e sexo, como se interpreta atualmente, conforme afirma Feix (2007). As oportunidades de acesso a essa prática eram bastante escassas.

Embora restrito, conforme explicado anteriormente, essa prática esteve presente na fala de todas as idosas participantes do estudo. A presença desse fenômeno parece ser orientada pela perspectiva psicológica, segundo a qual o lazer é visto como satisfação de uma necessidade humana complexa. Portanto, como uma necessidade, seja de compensação, seja de repouso, seja de diversão. Considerando o que aponta a literatura (Dumazedier apud Aquino; Martins, 2007; Nunes; Hutz 2014; Requixa apud Aquino; Martins 2007; Marcellino apud Feix, 2007; Camargo apud Aquino; Martins, 2007), o lazer, em maior ou em menor medida, foi vivenciado pelas depoentes.

\section{Considerações finais}

As práticas de lazer das idosas na adolescência foram bem limitadas. Essas limitações eram decorrentes das regras socioeconômicas e culturais impostas para as meninas de famílias pobres, além da total ausência de polí- 
ticas públicas voltadas ao setor. As obrigações com as tarefas domésticas, da maioria delas, que moravam com famílias estranhas em troca de moradia, comida e roupa, marcaram as condições socioeconômicas e, consequentemente, restringiam suas vivências de lazer.

Apesar da situação descrita anteriormente, sempre que surgia uma oportunidade as adolescentes dançavam, frequentavam balneário e iam à única praça da cidade passear, seja na companhia de irmãos ou vizinhos; seja na companhia de amigas da escola. A cidade também oferecia clubes e cinema, entretanto, nem todas tinham as condições financeiras necessárias para frequentar esses espaços de lazer. Por esse motivo, os balneários e a praça eram os espaços mais frequentados.

\section{Referências}

ALMEIDA, M.A.B.; GUTIERREZ, G.L. O Governo Vargas e o desenvolvimento do lazer no Brasil. Revista Digital. Buenos Aires. Año 10. N. 92. jan, 2006. Disponível em: <http://www.efdeportes.com/efd92/vargas.htm >. Acesso em: 2 abr. 2017.

AQUINO, C.A.B.; MARTINS, J.C.O. Ócio, lazer e tempo livre na sociedade do consumo e do trabalho. Revista Mal-estar e Subjetividade. Fortaleza, v.VII, n.2, p. 479-500. set./2007. Disponível em: 〈http://pepsic.bvsalud.org/pdf/malestar/v7n2/13.pdf〉. Acesso em: 2 abr. 2017.

BARROS, M.A. Curso de Direito do Trabalho. 7.ed. São Paulo: LTr, 2011.

BIRMAN, J. Adolescência Sem Fim? Peripécias do sujeito num mundo pós-edipiano. In: CARDOSO, M.R.; MARTY, F. (Orgs.). Destinos da adolescência. Rio de Janeiro: 7 Letras, 2008.

BLEFARI, A.L. Adolescência, família e drogas. Poder Judiciário de Mato Grosso. 2003. Disponível em: <http:/www.tjmt.jus.br/intranet.arq/cms/grupopaginas/105/988/Adolesc\%C3\%AAncia_fam\%C3\%ADlia_e_drogas.pdf>. Acesso em: 17 jul. 2017.

BRUHNS, H.T. Relações entre Educação Física e o lazer. In: BRUHNS, H.T. (Org.). Introdução aos estudos do lazer. Campinas: Edunicamp 1997.

CARNEIRO, E.A. O Ciclo da borracha no Brasil. Portal São Francisco. Disponível em: $<$ http://www.portalsaofrancisco.com.br/historia-do-brasil/ciclo-da-borracha $>$. Acesso em: 27 jul. 2017.

CAVALCANTE, S.R. Trabalho infantil artístico: do deslumbramento à ilegalidade. São Paulo: LTr, 2011. Disponível em: <https://juslaboris.tst.jus.br/bitstream/hand- 
le/20.500.12178/38639/014_cavalcante.pdf?sequence=1\&isAllowed=y>. Acesso em: 2 set. 2017.

CUSTÓDIO, A.V.; VERONESE, J.R.P. Trabalho Infantil Doméstico no Brasil. São Paulo: Saraiva, 2013.

D’AGOSTINI, M.; BACILIERI, S.; VITIELLO, N.; HOJO, H.; BILYNSKYJ, M.C.V.; BATISTA FILHO, A.; REBOUÇAS, M.M. Ciclo econômico da borracha: seringueira Hevea Brasiliensis (HBK) ARG S. Instituto Biológico. São Paulo, v.9, n.1, p.6-14, jan./ jun., 2013. Disponível em: <http://www.biologico.sp.gov.br/docs/pag/v9_1/dagostini3. pdf $>$. Acesso em: 15 jul. 2017.

FEIX, E. O esporte e lazer da cidade e as fases da vida. In: FERREIRA, M.P.A.; MARCELLINO, N.C.(Orgs.). Brincar, jogar, viver. Programa Esporte e Lazer da Cidade. v. I, n. 1, jan./2007. Disponível em: <http://www.esporte.gov.br/arquivos/publicacoes/livroV1. pdf>. Acesso em: 1 ago. 2016.

FERNANDES, D.M.; COELHO, A. B. Revisitando o Conceito de Vulnerabilidade. In: NORONHA, V. (Org.). Pensando sobre políticas públicas de lazer para juventudes em contextos de vulnerabilidade social: contribuições a partir de pesquisa em Ribeirão das Neves. Minas Gerais. Belo Horizonte: Editora, 2009.

GOMES, C.; PINHEIRO, M.; LACERDA, L. Direitos sociais: Questão de acesso e participação. In: Lazer, turismo e inclusão social: intervenção com idosos. Belo Horizonte: UFMG, 2010. Disponível em: <http://www2.esporte.gov.br/arquivos/snelis/esporteLazer/ cedes/lazerTurismoInclusaoSocial.pdf $>$. Acesso em: 16 ago. 2016.

GORAYEB, A. Território Federal do Guaporé. Coluna do Fundo do Baú. 2015. Disponível em: <http://www.newsrondonia.com.br/noticias/territorio+federal+do+guapore/63083>. Acesso em: 23 jul. 2017.

LEANDRO, R.V. Os ciclos ficcionais da borracha e a formação de um memorial literário da Amazônia. Universidade de Brasília. Instituto de Letras. Departamento de Teoria Literária e Literaturas. Programa de Pós-graduação em Literatura. Brasília-DF. 2014. Disponível em: <http://repositorio.unb.br/bitstream/10482/17742/1/2014_RafaelVoigtLeandro.pdf. Acesso em: 21 jul. 2017.

MARCELINO, N.C. Lazer e humanização. Campinas: Papirus, 1983.

MARTINS. W.H. Capricho do absurdo. A morte prematura da República Socialista do Guaporé. SECEL. Porto Velho: Graffporto, 2012.

MENDONÇA, L.C.P.; SILVA, E.A.P.C.; OLIVEIRA, N.S.; DANTAS, E.R. Pelo direito ao lazer: participação e mobilização social no bairro do Santa Rosa. Campina Grande: EDUEPB, 2009. Disponível em: < http://books.scielo.org/id/ggfcb/pdf/lemos-9788578791223-05.pdf>. Acesso em: 22 jul. 2017. 
MOTTA, D. Uma análise da adolescência ao longo da história. Rev. FAPERF. Apoio à Ciência, Tecnologia e Inovação no Estado do Rio de janeiro. 2010. Disponível em: <http:// www.faperj.br/?id=1654.2.5 >. Acesso em: 14 jul. 2017.

NASCIMENTO, C.P.O processo de ocupação e urbanização de Rondônia: uma análise das transformações sociais e espaciais. Revista de Geografia. Recife: UFPE - DCG/NAPA, v. 27, n. 2, maio/ago. 2010. Disponível em: <http://www.revista.ufpe.br/revistageografia/ index.php/revista/article/view/252/22>. Acesso em: 5 maio 2017.

NUNES, M.F.O.; HUTZ, C.S. Análise da produção de artigos científicos sobre lazer: Uma revisão. In: Rev. Psic. Teor. e Pesq., Brasília, v.30, n.3, jul./set. 2014. Disponível em: <http:// www.scielo.br/scielo.php?script=sci_arttext\&pid=S010237722014000300008 >. Acesso em: 1 ago. 2016.

PORTAL DA AMAZÔNIA. Borracha: apogeu e decadência. Disponível em: <http:// portalamazonia.com.br/secao/amazoniadeaz/interna.php?id=114>. Acesso em: 20 jul. 2017.

POSSAMAI, A.M.; GASTAL, S.; NEGRINE, A.A. viagem na memória do idoso. Anais da Associação Brasileira de Pesquisa e Pós-graduação, 2009. Disponível em: <https:// www.anptur.org.br/anais/anais/files/6/56.pdf>. Acesso em: 1 ago. 2017.

QUEIROZ, R.D.M. O trabalho infantil no Rio Grande do Norte: um panorama da situação ocupacional das crianças e adolescentes na região metropolitana de Natal no ano de 2010. Universidade Federal do Rio Grande do Norte. Centro de Ciências Sociais Aplicadas. Departamento de Economia. Monografia. Graduação. 2014. Disponível em: <https://monografias.ufrn.br/jspui/bitstream/123456789/1339/1/Otrabalhoinfantil_Monografia.pdf >. Acesso em: 17 jul. 2017.

SOUSA, R.G. Ciclo da Borracha. Brasil Escola. Disponível em: <http://brasilescola.uol. com.br/historiab/ciclo-borracha.htm>. Acesso em: 22 jul. 2017.

VIEIRA, S. A. B. Os parques infantis da cidade de São Paulo (1935-1938): análise do modelo didático-pedagógico. Revista de Iniciação Científica da FFC. v. 4, n.1, 2004. Disponível em: <http://www2.marilia.unesp.br/revistas/index.php/ric/article/viewFile/75/77>. Acesso em: 2 abr. 2017. 



\title{
5. MATURIDADE: MANIFESTAÇÕES DE LAZER NA HISTÓRIA DE VIDA DE IDOSẢS DE PORTO VELHO
}

\author{
Ivete de Aquino Freire \\ Ramón Núñez Cárdenas \\ Rosa de Luz Ambrósio dos Reis Miranda Sá \\ Paola Tristão de Lima
}

\section{Introdução}

A idade adulta é um estágio da vida que, igualmente aos demais ciclos, apresenta suas características próprias. Além daquelas relacionadas ao desenvolvimento humano com enfoque biológico, também ressaltam os aspectos produtivos e as relações interpessoais de um modo diferente daquele da criança e do jovem (Oliveira, 2004). Dentre esses fatores, também se destacam as variáveis socioculturais. Decorrente dessa multiplicidade de dimensões, é comum encontrarmos afirmações como a de Alves e Marcellino (2010), com a qual concordamos: não é fácil identificar em que momento uma pessoa se torna adulta. Apesar das dificuldades, os autores optam por considerar adulto:

O grupo de pessoas que assume novas responsabilidades e consegue, em alguns momentos, identificar sentido e significação em suas ações e essencialmente tem obrigações a cumprir. Em sua grande maioria, os adultos são responsáveis pelo sustento próprio e/ou da família e são vistos pela sociedade como pessoas produtivas no tempo de trabalho. São, ainda, os mantenedores da relação de produção e consumo do sistema econômico instaurado em nossa sociedade. (Alves; Marcellino, 2010, p. 104).

Além das responsabilidades assumidas, sobretudo aquelas relacionadas com o sustento da família, citam ainda os autores que a maturidade representa uma fase de crescente obrigação e produtividade. 
Oliveira (2004) destaca que, ao se abordar aspectos relativos à idade adulta, é importante que sejam contextualizados na discussão, que se explicite a que adultos se está fazendo referência. Parece que o autor guarda restrições sobre uma análise generalizada do adulto, exatamente como ocorre nas demais etapas da vida. De fato, em um sistema capitalista, por exemplo, no qual a maioria da população vivencia o trabalho como principal ocupação, é diferente de outros sistemas sociais que valorizam as distintas dimensões de expressão humana. Igualmente, dentro de um mesmo sistema capitalista, se distinguem as condições de trabalho e de vida em geral, de populações mais abastadas quando comparadas com aquelas de estratos socioeconômicos mais baixos. Nesse contexto, mais do que considerar uma caracterização geral, é importante inserir em uma análise toda a trajetória de vida desse adulto, apreciando, inclusive, sua origem sociocultural.

Os adultos a que vamos fazer referência neste item são mulheres, que nasceram na região Amazônica Brasileira, residentes na cidade de Porto Velho, no Estado de Rondônia, ou que vieram ainda crianças para a localidade. Assumiram a responsabilidade que a maturidade lhes impunha através do casamento e construção de uma família. Em sua maioria, exerceram na infância e na adolescência trabalhos domésticos, dentro e/ou fora do lar; e não remunerado.

Essas mulheres viviam em um contexto específico, na Amazônia, mais precisamente em uma localidade (Porto Velho), que à época sofreu três mudanças na sua identificação geográfica. Conforme Gorayeb (2015), até 1940, a localidade era município do Estado do Amazonas; a partir desta data, é instituído como um município do Território Federal do Guaporé; e, em 1956, se torna município do Território Federal de Rondônia. Três décadas mais à frente (em 1981) é elevada a capital do Estado de Rondônia.

Nesse contexto apresentado, o presente trabalho estuda as manifestações de lazer de idosas Amazônicas, residentes em Porto Velho durante a fase adulta. A fim de melhor orientar essa proposta geral, determinaram-se os seguintes objetivos específicos: a) Identificar e caracterizar as práticas de lazer das idosas quando se encontravam na idade adulta; b) Estabelecer relação entre as práticas de lazer e o contexto social, econômico e cultural 
das mulheres; c) Relatar os espaços de lazer utilizados; d) Descrever os materiais e equipamentos utilizados nas práticas de lazer; e) Identificar os distintos grupos de compartilhamento de práticas de lazer das mulheres.

Dentre os conceitos de lazer, é comum a identificação do termo "tempo livre". Essa expressão adquire importância no contexto deste trabalho na medida em que as manifestações de lazer estudadas ocorriam em um período em que se iniciavam as discussões teóricas, nos grandes centros de pesquisa do mundo, sobre o tema, e as políticas públicas brasileiras nesse setor eram inexistentes. Somado a essa questão, recorremos a Moura e Souza (2013), quando destacam que, no decorrer da vida, se percebe que a quantidade de tempo livre é maior na infância e adolescência, diminuindo na fase adulta e aumentando com a aposentadoria. Isso porque, conforme já comentado anteriormente, é na fase adulta que o indivíduo assume novas responsabilidades, ocupações e compromissos sociais.

\section{Pressupostos metodológicos para estudo de Trajetória de Vida}

Considerou-se que a maturidade das idosas ocorreu no período entre 1947 e 1995, dependendo do ano em que nasceram, conforme explicita a Figura 1.

Figura 1 - Demonstrativo das variações de período da história em que as idosas se encontravam na Maturidade

\begin{tabular}{|c|c|c|c|c|c|}
\hline $\begin{array}{c}\text { Ano de } \\
\text { Nascimento }\end{array}$ & 1928 & 1930 & 1931 & 1934 & 1937 \\
\hline $\begin{array}{c}\text { Quantitativo } \\
\text { de Idosas }\end{array}$ & 1 & 3 & 1 & 2 & 2 \\
\hline $\begin{array}{c}\text { Maturidade: } \\
\text { até os 59 } \\
\text { anos }\end{array}$ & $1947-1986$ & $1949-1988$ & $1950-1989$ & $1953-1992$ & $1956-1995$ \\
\hline
\end{tabular}

\section{O lazer na trajetória e vida das mulheres adultas da Amazônia}

Apesar de este estudo não tratar com profundidade os aspectos socioculturais das mulheres da Amazônia, e ter como foco principal as 
manifestações de lazer delas, esses conceitos virão à tona na medida em que se se faz necessário mencionar em que contexto viviam essas mulheres e, principalmente, como viviam. Seguindo o que diz Oliveira (2004), ao se abordar aspectos relativos à idade adulta, importa que sejam contextualizados, na discussão, a que adultos se está fazendo referência. Aqui se fará um passeio pelos aspectos sociais, políticos, econômicos e culturais, a fim de contextualizar o cotidiano dessas mulheres. É desse cotidiano que emergem ou não as práticas de lazer.

A partir dos relatos, foi possível observar que, conforme a literatura (Oliveira, 2004; Alves; Marcellino, 2010), as mulheres, para serem consideradas adultas, nem sempre a idade era o fator principal. O casamento e os filhos, que em alguns casos vinham precocemente, eram os fatores que abriam as portas para a vida adulta, a exemplo de Jurema, que foi mãe solteira aos 16 anos; e Aracy e Anahi, que se casaram com essa mesma idade.

Foi quando eu trabalhei já lá [No Seringal]. Foi aí que eu comecei namorar. Ai teve um, namorei, namorei, namorei até com um primo meu. Eu namorei que acabei me emprenhando dele. E não casei nem nada. Teve um filho que ele, que era essa que é a [Diz o nome da filha], com ele (Jurema).

Assim, Jurema teve seu primeiro filho aos 16 anos, assumindo a condição de mãe solteira. De acordo com Levy (2009), nas famílias de estratos socioeconômicos mais altos, o defloramento e crimes como a sedução e o estupro eram vistos como violência "moral" ao pai da vítima, contra a honra da família toda. Desse modo, se o crime fosse de sedução, a pena era indenizatória; e de prisão, se o estupro (sedução) fosse por violência e rapto. Ocorre que Jurema teve uma infância e adolescência muito difícil. Não conheceu seus pais e nem avós. Teve uma irmã e duas tias como referência familiar consanguínea. $\mathrm{Na}$ primeira infância, morou com a irmã e, mais tarde, a partir da segunda infância, foi entregue em adoção informal para uma família de desconhecidos. Nessa época, era comum famílias mais abastadas economicamente pegarem crianças e adolescentes pobres para assumirem os trabalhos domésticos em troca de casa, comida e roupa. 
Jurema, por exemplo, não teve acesso à escola e foi explorada pela família que a “adotou”. Ela era a responsável por todos os labores domésticos, além de trabalhar na roça.

Segundo Levy (2009), ocorrido o desvirginamento, o homem era obrigado a casar, e o matrimônio dava-se às pressas. Também havia casos em que o homem era obrigado, por sentença judicial, a pagar um dote à prejudicada. Tal sentença foi ainda observada na cidade de Salvador, em 1972 (Azevedo apud Levy, 2009).

Entretanto, com sua trajetória de vida e condição social, é compreensível que Jurema não contasse com a família ou o poder público para acolhê-la nessa nova condição. Criou sua filha sozinha, trabalhando de lavadeira e como empregada doméstica em casas de família, dessa vez com remuneração.

Todas as depoentes foram casadas, inclusive Jurema, que contraiu matrimônio pela segunda vez aos 51 anos. A idade de casamento das participantes deste estudo, em sua grande maioria, ficou entre 18 e 22 anos; com exceção de Tainá que casou com 28, e Aracy e Anahi, que casaram com 16 anos. Desse modo, quando considerado o fator idade, a adolescência e a maturidade destas últimas depoentes se confundem. Descreve Levy (2009) que na área rural de Bofete (SP), no final da década de 1940, a idade mais comum para se casar era de 15 a 16 anos para as mulheres, com limite inferior de 13 e superior de 20 anos, sendo que depois dos 30 era difícil arranjar casamento para ambos os sexos. A faixa etária em que a maioria das depoentes se casou não acompanha os estudos do autor, o que chama a atenção, pois, considerando que a exceção de Tainá, que teve uma infância e adolescência com total atendimento de suas necessidades primárias e de lazer, as demais depoentes tiveram uma trajetória de vida de privações diversas. Essa condição poderia indicar a busca de melhoria de vida através do casamento, fato que não foi observado.

Dentre as depoentes, apenas Iracema mencionou que não escolheu o seu marido, sendo esta uma decisão da família que a criou. Iracema foi entregue pela mãe, em adoção, a uma família turca, que morava no Brasil, e residiu com essa família até se casar, em 1950, com 20 anos. A não escolha 
do marido, conforme aconteceu com Iracema, era um fenômeno comum entre as classes socialmente privilegiadas do período colonial no Nordeste (Levy, 2009). Complementando essa ideia, Mambrini (2010) afirma que, no Brasil, até o final da década de 1930, as meninas tinham seu casamento arranjado pela família. Com Iracema essa ocorrência se dá duas décadas após supostamente esse tipo de fenômeno já haver sido extinto.

Todas as depoentes tiveram filhos. O número de filhos paridos era elevado, acompanhando a cultura na época. Janaína, por exemplo, teve 10 filhos; Anahí e Iracema tiveram 13. Esses dados encontram-se em conformidade com o que diz a literatura, quando afirma que, na década de 1940, até 1950, a média de filhos era de 8 a 10 por casal (Departamento de Vigilância, Prevenção e Controle das IST, do HIV/Aids e das Hepatites Virais, 2006).

Dentre as 9 depoentes, 3 tiveram filhos falecidos ainda na infância (Iracema, Taynara e Yara), o que parecia ser um fato bastante comum na época.

Tainá foi a única depoente que concluiu os estudos e teve uma profissão. Em sua casa, contava com a mãe e uma adolescente, que "ajudava a cuidar dos labores domésticos e das crianças”.

Trabalhava. Eu comecei a trabalhar em 50, em escola. Sempre lecionei. Sempre professora. As crianças ficavam com minha mãe e uma moça. Sempre tinha em casa [Fala baixinho]. Foi antes de me formar, eu comecei trabalhar. Eu formei em 51 e comecei a trabalhar em 50, ou antes porque eu trabalhei na divisão de obras na época era divisão, não era a secretaria. [...]. Olha sempre, eu sempre morei com a minha mãe minha mãe, né? Minha mãe faleceu em 79. Tinha minha mãe, a gente sempre tinha uma pessoa conosco e naquele tempo era fácil conseguir uma pessoa pra a gente ter em casa, né? Sempre tinha alguém em casa, tinha lavadeira (Tainá).

Tainá também foi a única mulher participante do estudo que falou sobre a parceria que tinha com o marido, no que diz respeito à divisão das tarefas. 
"É ... [Pensando]. Ou então ficava eu e ele. Cansamos de ficar noites e noites, final de mês acordados somando notas do [Nome da escola em que Tainá trabalhava], tirando média pra colocar a as notas no quadro no dia seguinte, que naquela época não existia calculadora. Tudo era na cabeça e [Não conclui]. Uma época nós tivemos 60 turmas no [Nome da escola], de manhã à tarde à noite. Ai somar tudo, tirar média, preencher [Incompreensível] [Risos] que também de noite [Não conclui]. Tinha uma máquina velha Rema [Marca da máquina], que era deste tamanho assim [Risos... Demostra com as mãos o tamanho da máquina) (Tainá).

Com exceção de Tainá e Iracema, todas as mulheres pesquisadas tiveram momentos ou toda a maturidade de privação. A presença do trabalho foi uma constante na vida dessas mulheres, o que é frequente no discurso delas. Somente Iracema nunca trabalhou. No labor das demais predominam os trabalhos pesados em extensas jornadas na roça, de empregada doméstica e lavadeira.

[...]. Eu trabalbava a noite e lavava roupa pra fora de dia. Minha vida foi muito, muito pesada. Ai ele ia brincar [O filho]. Eu não tinha como ele comprar as coisas, ir num cinema. Então em casa tinha um pé de goiabeira, ele juntava as goiaba e ia vender pra pagar o cinemazinho dele, compra uma revista era assim a nossa vida. [...]. Às vezes eu frequentava [Não conclui]. Também, tomei conta duma, duma boate que era boate como é que se diz, que tinham as mulheres que iam pro quarto com os homens e eu tomava conta, eu lavava, arrumava tudo por lá (Apuana).

Trabalhava minha filha. Toda vida eu trabalhei muito; Quando eu sai da casa dos meus pais [Não conclui]. [...]. Lavava roupa, criava galinha. [...]. Foi assim, serviço de, de roça de, de fazer as coisas assim. Mas na casa dos meus pais eu trabalhava assim como eu tô te dizendo, de, né? (Anahi). [...]. Eu trabalhei primeiro no, na, no campo, no campo mermo, roçando lá, depois nós trabalbamo [Não conclui]. Ai quando foi eu passei um ano, né? Nesse serviço de Campo. Ai tinha um chefe que gostava muito de mim. Ai ele disse, eu vou arrumá serviço pra ti fora daqui. Ai ele arranjou já pra me botar numa casa de farinha. Só para descascar mandioca, pro pessoal fazer farinha. Aí foi que eu saí do Campo. Ai eu fui trabalhar lá na farinha. Ai 
lá na farinha eu trabalhei um bocado de tempo. Depois eu saí. Foi o tempo que eu vim já pra, pra Manaus de novo, pra Santarém de novo. Ai [Não conclui]. E nós viemos para cá em 51 [Para Porto Velho]. [...]. Não. Aqui não trabalhei em canto nenbum [Afirmando que não trabalhou quando chegou em Porto Velho]. Lavei foi roupa, só lavá roupa. Ainda trabalhei na casa de família uma vez. Não, duas vez trabalhei na casa de família. [...] quando eu sai de lá passei um tempo. Que trabalhei num bar, tinha um barzinbo lá no meio da rua. É, tinha um, um bar por ali [Sinaliza com a mão], logo na entrada das rua. Ai eu trabalhei lá um [Não conclui]. Num cheguei a trabalhar dois mês, porque não aguentei. Não gostei de trabalhar lá, não podia dormir de dia. Eu não dormia. Ai, de noite eu tinha que trabalhar. Ai o meu o horário trabalhado à meia-noite até de manhã. Ai eu ficava com medo de dormir e perder a hora. Ai eu fiquei naquela... [Não conclui. Pensando]. Ai, é lavá roupa, cuidá da casa e [Não conclui]. Por mês e por peça [Sobre o pagamento]. Ai já lavava pra ganhar dinheiro. No igarapé, igarapé mesmo [Local que lavava as roupas] (Jurema).

Ai, eu fui trabalhar lá no [Cita o nome da escola que foi trabalhar]. É, lavava roupa pra fora [Expressão usada na região para explicitar o trabalho de lavadeira] e...[Gaguejando] trabalhava de noite e inda servia de faxineira. Quando tinha casa pra fazer limpeza, eu ia, né? (Yara).

É, eu digo que vou da pro meus filho aquilo que eu não teve pra mim. Vou dá pros meus filhos. Tenho fé em Deus. Rastei sandalinha na rua, empurrava um carrinho vendendo as coisas que eu fazia todo tempo. Gostava de fazer, né? Os salgadinho, os docinho, tudo pra vender pra tirar dinheiro pra ajudar meus filhos. Meu marido trabalhava mas não ganhava essas coisas (Taynara).

Eu trabalhava na portaria [Da maternidade]. Ai de lá eu fui pra Fundação Nacional de Saúde e de lá me aposentei. Lá eu trabalhava no fax ali na Fundação (Janaina).

Grande parte do trabalho dessas mulheres não era e ainda não é, em alguma medida, valorizado como atividade produtiva, uma vez que se tratava de práticas de trabalho não legais, fora da qualificação social de rendimento, geração de riquezas e lucro. 
A exceção de prática de trabalho se deu com Aracy, no início da vida adulta. Quando estava casada, não estudava e nem trabalhava, porque o marido não permitia.

Tinha, tinha muita vontade de estuda e naquela época era tudo fácil aqui. Assim, quer estudá? Vá. E até trabalho. Eu tava, nem com 18 anos, Dona [Cita o nome da diretora de uma escola] mandou me chamar. Eu fui lá ela falou: você não quer trabalhar? Não. A vontade eu tenho, mas meu marido não deixa estuda. Não, mulher minha não sai de casa [...] (Aracy).

Mas a realidade de Aracy mudou. Com 6 anos de casada, ficou viúva e passou dificuldades com os 7 filhos, baixando o padrão de vida que tinham. Demorou meses para começar a receber a pensão do falecido marido que, por sua vez, não era suficiente para o sustento da família. Trabalhou como lavadeira e empregada doméstica em várias casas de famílias.

O primeiro emprego foi na igreja. Mas depois eu trabalhei lavando roupa para fora. Saía assim, de casa em casa. Eu só nunca trabalhei assim, é o unico canto que eu trabalhei o dia todo foi nas irmãs [Com as freiras]. Quando eu cheguei lá que eu pedi, ele disse quantos filhos você tem? [...]. Quantos filhos a senhora têm? Eu disse sete (Aracy).

Igual a algumas famílias pobres da atualidade, naquela época os filhos de Aracy e Apuana, à medida que iam crescendo, passavam a trabalhar precocemente para ajudar nas despesas da casa ou mesmo para garantir alguns momentos de lazer. Na época não havia uma estrutura de lazer e entretenimento sofisticados, a exemplo do que se observa atualmente, entretanto, já se ressaltava claramente a presença dos setores privados.

Pois é quando ele morreu [O marido], fiquei assim: eu era o pai e a mãe dos sete, né? A [Diz o nome da filha] nunca deu... [Pensando]. Já, já tinha 14 anos, né? Ai começou a trabalha, estudava, trabalhava. A [Diz o nome da outra filha] também. [...] saía pra procurar serviço. Ai, o pouquinho que ela ganhava, ela me ajudava, né? (Aracy). 
Ai, ele ia brincar. Não tinha como ele [Referindo-se ao filho] comprar as coisas ir num cinema então em casa tinha um pé de goiabeira ele juntava as goiaba e ia vender pra pagar o cinemazinho dele comprar uma revista era assim a nossa vida (Apuana).

Após 14 anos na condição de viúva, Aracy casou-se novamente e teve mais 3 filhos, totalizando 10 filhos paridos. A partir daí, iniciou no trabalho formal na condição de zeladora até se aposentar.

Ai, eu sem emprego, sem a pensão. Naquele tempo, o guarda [Profissão do marido] morria, passava às vez de até cinco meses sem receber. Só Deus sabe o que eu passei [...]. Foi depois quando eu fui lá e a diretora me deu emprego. Ela disse assim, para onde você quer ir? Quando eu arrumei lá já, já tava casada com [Diz o apelido do segundo marido]. Aonde é que você quer trabalhar? Eu disse, eu disse: eu nunca [Não conclui]. A senhora me dando emprego, pode ser onde for. Eu quero é ganhar meu dinheiro. A pensão que eu comecei receber dele era mixaria, que era do pai dela, né? Não. Era mixaria (Aracy).

Pessoas pediam para criar seus filhos, como era comum ainda naquela época (algumas depoentes foram dadas em adoção durante a infância). Mas mesmo diante de dificuldades, Aracy criou seus 10 filhos.

Foi. Ainda bem que a gente tinha uma casinha, né? A casa, não pagava aluguel. Ai, eu [Não conclui]. Elas tinha, a gente pedir. Todo dia chegava, gente: me dê uma filha sua. Eu não estou passando bem, não mas eu morro agarrado com meus filhos, mas não dou um filho meu. Não dou! (Aracy).

Nas residências dessas mulheres ocorria a mesma precariedade identificada durante a infância e adolescência, como moradoras das zonas periféricas da cidade de Porto Velho. O abastecimento diário das casas com água potável, que hoje é algo simples na localidade, naquela época era um verdadeiro desafio. 
[Não havia água encanada]. Não. A gente carregava a água do poço, quando não, da beira do rio, subindo ladeira com as latas na cabę̧a, os balde. [...]. Morava na casa do mesmo jeito [Do mesmo jeito da infância e adolescência]. De palha, coberta de palha, cercada de palha, chão batido (Apuana). Aqui mesmo em Porto Velho, lá tinha Igarapé que chamava em Igarapé dos Padre. Lá em cima [Sinaliza com a mão] tinha um Igarapé que chamava Igarapé dos Padre. Lá, a gente ia lavá roupa. Era. Ai, agora não tem mais não. Acabaram com tudo enterraram lá e fizeram em modificaram tudo, né? [...]. Não, não, não tinha água e nem luz, era luz de vela.[...] água tinha sabe aonde eu carregava água? Ali não tem ô ô ô. Vila Rica? [Um dos primeiros hotéis da cidade de Porto Velho]. Até hoje tem Hotel Vila Rica, né? Antigamente era outro nome que tinha ali. A gente vinha buscar bem ali naquela, naquela esquina de lá da minha casa. Eu morava na Carlos Gomes, uma quadra pra lá subindo dai do Vila Rica pra lá. Era. Os meninos vieram buscá água, buscá água lá na Carlos Gomes (Jurema).

Ah! Não. Eu passei muito tempo carregando água no poço. Era. Todo mundo tinha poço. Ai eu ia buscar água. Que era lata na cabeça, para dar banho nas crianças e almoço, encher as vasilhas (Aracy).

[Sobre água encanada na residência]. Tinha nada [Dando ênfase]. Pegava era do riacho. [Sinaliza com a mão explicando a localização do riacho]. Ai, nessas Pedrinba [Nome de um bairro], agora tá tudo fechado (Taynara).

Não. [Dizendo que a sua residência não dispunha de água encanada]. Mas depois colocaram. Antes era poço que tinha. Tirava água de poço. (Anahi)

Para algumas mulheres, a água do poço, igarapés e rios não era utilizada para lavar roupa. Para a realização dessa tarefa elas iam ao Parque dos Tanques ${ }^{1}$.

[Sobre o parque dos Tanques] Ficava muito longe. Lá só ia lavá, lavá. Juntava roupa semana, para ir com aquela bacia desse tamanho [Demonstra com os braços]. Eu fiquei quase aleijada. Que às vezes a gente vinha

\footnotetext{
${ }^{1}$ Espaço público localizado em área fora dos arredores da cidade, dotado de tanques e torneiras para uso coletivo de lavagem de roupa.
} 
com roupa quase molhada, né? De noite eu não podia dormir. Quando o sol tava bom, secava, né? Era um sofrimento muito grande (Aracy).

A água é um bem de primeira necessidade, sendo utilizada fundamentalmente no dia a dia para o preparo de alimentos, para beber, higiene, asseio corporal e banho (Pontes; Schramm, 2004). Portanto, a água potável é um dos serviços básicos primordiais para a sobrevivência e saúde. Mas o acesso fácil à água potável estava fora da realidade dessas mulheres. $\mathrm{O}$ mesmo ocorria com a luz elétrica.

Tinha nada [Referindo-se à água encanada]. Pegava era do riacho. [...]. Ai, comecei trabalho. Olha, levantava de madrugada, cedinho ia pra lá mais minha vizinha lavá roupa. Chegava aqui. [...]. Acendia uma lamparina com querosene num tem, tem um farolzinho, farol. Ai ficava na lua, claro da lua. [...]. Ai que novela essa minha vida (Taynara).

Não. [Refere-se à energia elétrica e à água potável] [...] Era poço e tinha o garapé [Igarapé] [...]. Ai eu lavava roupa lá, era na bera [Referindo-se ao local em que lavava a roupa] (Iracema).

A diferença na oferta dos serviços básicos nas localidades de moradia das depoentes quando comparada com o centro da cidade era tão gritante que Tainá chega a confundir-se se morava ou não no município de Porto Velho.

Olha, em Porto Velho [Referindo-se a zona central da cidade] existia, mais aqui não tinha nem energia e nem água encanada (Tainá).

A insegurança não se limitava às dificuldades para acesso à água potável e energia elétrica, mas ampliava-se também na precariedade das construções das residências. A pobreza das casas era refletida pelos tipos de materiais utilizados na construção.

Ai, tinha minhas sobrinha que passava e dizia que minha casa era a casa dos 3 porquinho. Que era como camburão de esfalto, o beral, né? E em cima era palha. Diz que era a casa dos 3 porquinho. Assim, redonda du, du da tape- 
rinha era lençol Santista [Marca do tecido] era a nossa parede. Fogão eu fazia carvão daqueles pauzinho do mato, né? Quando a gente cozinha [Não conclui]. E sofri. Sofri mesmo. Por isso que é bom sofrer quando é nova pra depois de velha ter um lazer, né? (Taynara).

[...]. Aqui era uma invasão, minha casa [Falou baixinho]. Tenho até vergonba de dizer. Era de furquilha [Forquilha], de pau do mato do igapó [Tipo de vegetação característica da floresta Amazônica]. Ai em cima era palha, pra poder sair do aluguel. Meu marido ganbava poquinho, e eu ainda não trabalhava (Taynara).

Quando eu me casei eu vim morar na minha casa. Mas a minha casa era de taipa. [...]. É uma casa que é rodeada de o telhado é coberta de palha é é rodeado com unssss paus assim [Demonstra com as mãos] e colocado barro, barro mole e colocado ali e fazia a parede, era ali [Explicando o que é uma de taipa] (Yara).

Minha casinha era de cerca, de madeira de e tálbua, e coberta de palha (Anahi).

As casas de taipa, presentes na infância e adolescência de algumas depoentes, ainda se mantêm durante a maturidade. Esse tipo de residência contrastava com as casas confortáveis que foram construídas no Bairro Caiarí destinada aos funcionários da Estrada de Ferro Madeira Mamoré; igualmente eram diferenciadas daquelas do centro da cidade, majoritariamente pertencentes aos donos de comércio.

Conforme dito anteriormente, a maioria das depoentes se somava à população que ocupava a periferia de forma rarefeita, em bairros sem nenhuma infraestrutura dos serviços básicos, tais como água potável e energia elétrica. Entretanto, segundo os historiadores, a partir do período entre 1890 a 1920, a cidade de Porto Velho, na zona central, onde se dava o adensamento populacional, contava com infraestrutura como eletricidade, sistema de água encanada e esgotos, museus e cinemas. Tudo construído a partir da exploração do látex na região Amazônica (Leandro, 2014; Souza, 2017; Portal da Amazônia, 2017). Ocorre que, como residiam na periferia da cidade, possivelmente as depoentes viviam um cotidiano distinto ao dos moradores residentes da zona central. 
Conta Perrot (1989) que, sob forte influência do século XIX, a vida das mulheres de classes econômicas mais favorecidas residentes nas cidades da Amazônia, durante o ciclo da borracha, era diferente da vida daquelas de classes menos privilegiadas economicamente. É fato. Entretanto, pela fala das depoentes, constata-se que essa realidade permaneceu mais além do que relata o autor. A situação socioeconômica e a inacessibilidade aos serviços públicos básicos de água, energia elétrica e condições dignas de moradia das famílias pobres de Porto Velho, conduzem à interpretação de que elas viviam um cotidiano bastante distinto ao das mulheres residentes na zona central da cidade. .

As dificuldades financeiras também são retratadas por Taynara, ao falar da precariedade na alimentação da família. A pobreza econômica, as condições de insalubridade da região, da localidade e das residências, vinculadas à falta de saneamento básico, como não poderiam ser diferentes, refletiam negativamente na saúde da população, em especialmente na das crianças.

Passeiii [Fala dando ênfase] dificuldade mermo. Uma lata de sardinha nóis passava uma semana e não [Não conclui]. Terminava todo mundo doente de malária. Era tanta coisa. [...]. Minha flinha quase morre de malária. Meus filhos tudo doente. Mana, minha vida foi uma novela. [...]. [Diz o nome do filho] esse marido da baratinha [Apelido da nora], ninguém dizia que ele escapava, Eu, eu, já trabalhando, peguei malária. Fui pro hospital. Quando tava lá, escutava choro dos meus filhos na pediatria, dizia: Minha Irmã esse é o choro dos meus filhos. Ela: não. Eu digo: é. Levantei tombando, fui lá, todo mundo doente. Sofri, sofri mana. [...]. Nas pedrinhas [Referindo-se ao bairro que foi morar durante a maturidade e reside na atualidade], só tinha [Não compreensível], malária e tudo que não prestava (Taynara).

A malária foi a grande vilã no setor da saúde ao longo do processo de ocupação da Amazônia como um todo. Martins (2012) conta que perdeu sua mãe, no Estado do Pará, quando tinha 15 anos de idade, após a 15a infecção por malária. 
De acordo com Katsuragawa, Soares Gil, Tada e Silva (2008), Rondônia em especial, sofreu desse tipo de epidemia, no início do século XX, na construção da Ferrovia Estrada de Ferro Madeira-Mamoré; e, na segunda metade deste mesmo século, quando volta a sofrer nova onda migratória. Neste último caso, originada pelo projeto de integração nacional do Governo Militar, além da exploração de ouro nos leitos de seus rios.

[...] más condições das moradias, concentrações humanas desorganizadas, falta de infraestrutura sanitária e invasão predatória da floresta determinam a eclosão de importantes surtos de malária, com altos níveis de morbidade e mortalidade associados (Katsuragawa, Soares Gil, Tada; Silva, 2008, p. 3).

Conforme afirmou Taynara, a epidemia de malária que assolava Porto Velho a acompanhou durante sua maturidade. Essa informação é confirmada na publicação de Katsuragawa, Soares Gil, Tada e Silva (2008). Segundo os autores, o número de casos de malária em Rondônia aumentou de alguns milhares para mais de 300 mil ao ano, no final da década de 1980. Não foi à toa que Rondônia recebeu, na época, o título de "Capital mundial da malária".

Além de problemas com mosquitos vetores de malária, algumas mulheres passaram por graves problemas com seus companheiros. De modo indireto, algumas depoentes dão a entender que viveram momentos de violência ou de abandono em seus matrimônios. Algumas deixam claro que passaram por sérias dificuldades com seus companheiros.

Eu já tinha separado do primeiro marido porque ele quis me matar, né? E pegá meu menino. Ai eu fugi dele. Ai, depois eu me juntei com esse outro. Aí ele [Não conclui]. Eu ia trabalhá, deixava a criança. Ele arrumou uma amante e fazia conta no meu nome [Risos], pra mim pagar, né? Enrolada a minha vida [Risos] (Apuana).

Minha filha, vamo, pá, pá incurtá a história. Vamo sê fran, vamo, vamo falar direitinho o negócio. O meu jogo [Risos]. Meu marido me deixou [Incompreensível] depois de cinco filhos e eu criei mais um [Adotou]. Que veio de, sob encomenda (Yara). 
Segundo Levy (2009), no século XIX até a Constituição Brasileira de 1988:

[...] para a população dos estratos socioeconômicos mais baixos os padrões de moralidade eram mais flexíveis, e quase não havia bens a dividir ou oferecer; talvez por isso essas uniões eram mais facilmente desfeitas, pois, esmaecendo o estímulo inicial, não havia razões no plano pessoal para preservá-las e, no plano social, a separação ou um novo concubinato não apresentavam graves consequências" (p. 4).

Levy fala da facilidade com que as famílias mais pobres lidavam com a separação. No evento com Yara, o que houve foi o abandono da família por parte do cônjuje; e Apuana teve que fugir do marido que a ameaçava de morte.

As famílias chefiadas por mulheres são, em grande parte, decorrente, entre outros aspectos, de abandono por parte do parceiro. Não raro essas mulheres foram ou ainda são vítimas de violência doméstica em suas mais variadas vertentes, incluindo-se a "invisível", aquela que não deixa marcas exteriores, mas sequelas profundas em relação à autoestima e à busca ou reconstrução de identidade como mulher, como cidadã, e aos preconceitos decorrentes da relação de gênero (Pinto et al., 2011).

Aracy, por exemplo, que casou ainda adolescente, conta que ficava em casa sozinha enquanto seu marido saía para se divertir.

É. Aí eu ficava, que ele saía muito Iá, pra [Incompreensível] pás farra dele. Que ele tomava uns e eu ficava só. Não ia na casa de vizinho (Aracy).

As atividades de lazer das depoentes na fase de maturidade, assim como na atualidade, estavam condicionadas a diversos fatores, conforme afirma Marcellino (1993). Quase sempre a excessiva carga de trabalho, caracterizada pelas múltiplas atividades que exerciam simultaneamente, restringia as atividades de lazer. Nesse caso, se inclui dupla ou tripla jornada de trabalho. Essa rotina de labor de algumas depoentes era uma prática feminina de trabalho que se assemelha àquela que teve início entre os séculos XVIII e XIV, conforme afirma Spindola (2011). 
Não, Não [Dizendo que não usufruía de momentos de lazer]. Não, porque eu trabalhava. [...]. Eu não tinha lazer. Era só trabalhá e cuidá das coisas. Trabalhar no roçado. Às vezes pra eu ir em uma festa eu ia, mas eu ia vendê. Fazia bolo de mandioca e ia vendê bolo, vendê suco pra arrumá um dinheirinho (Apuana).

Os meninos sempre iam pra matinê, essas coisas [Referindo-se aos filhos]. [...]. Nem ele [Referindo-se ao marido] não saía quase. Não saia. Não, não. Nem lembrava dessas coisas [Referindo-se a lazer]. Era só mermo fazer as coisas e pronto. Trabalhá, limpá casa, lavá roupa, fazer essas coisas. (Jurema).

Era só trabalho [Usando esta expressão para dizer que não tinha atividades de lazer] (Tainara).

Saía não. Saía não. Só tem, ficava em casa cuidando de criança [Referindose à atividade de lazer] (Iracema).

Não. [Dizendo que não tinha lazer nesta etapa da vida]. Tinha não. Só vivia em casa mermo. [...]. Não... só isso mermo. Só brincadeira pouca. Carregá água na cabeça. Lá da, de frente da igreja. [Muda o tom de voz mais alto com mais segurança]. Só que a igreja não era como é agora, né? A frente dela era pro Madeira [Fazendo referência ao Rio Madeira, que corta a cidade de Porto Velho]. Agora que depois que ajeitaram que butaram a frente dela pra cá (Janaina).

Ai, eu fui trabalhar lá no Carmela Dutra [Nome de uma escola]. E... lavava roupa pra fora e... [Pausa] trabalhava de noite e inda servia de faxineira. Quando tinha casa pra fazer limpeza, eu ia, né? Era o meu lazer na época. Tinha não [Referindo-se ao lazer]. Só de casa mermo (Yara).

De lazer não fazia nada, só trabalhá mesmo. Não, num ia porque não dava tempo, trabalhava muito minha filha. E eu ia sair? Tu sabe que hora eu ia pro meu trabalho? 5 horas da manha" (Anahi).

Em alguns casos, a presença de mulheres em espaços de lazer não era para divertir-se, e sim para trabalhar, o que igualmente ocorre na atualidade com a classe mais pobre. $\mathrm{O}$ trabalho informal em espaços de lazer é mencionado por Apuana. 
Eu não tinha lazer. Era só trabalhar e cuidar das coisas. Trabalhar no roçado, às vezes pra eu ir em uma festa, eu ia, mas eu ia vender. Fazia bolo de mandioca e ia vender bolo, vender suco pra arrumar um dinheirinho (Apuana).

No século XIX, as mulheres moradoras da zona rural da Amazônia, durante o ciclo da borracha, para sustentar os filhos ou contribuir com o marido no sustento da casa, enfrentavam longas jornadas de trabalho até mesmo labores mais "pesados" que, historicamente, considera-se que exigem a virilidade associada ao homem (Perrot, 1989). Yara é um exemplo de mulher cuja trajetória de vida identifica-se com o que diz esse autor.

Quando ainda estava casada, compramos um boi com o dinheiro que recebi. Trabalhava a contragosto do marido. Ia buscar carvão na mata fechada [Trabalhava com compra e venda de carvão]. Os homens ensacavam e botavam na carroça e eu trazia para vender [Trazia para a cidade] (Yara).

O exemplo de Yara acompanha também o que diz Carvalho (apud Pinto et al., 2011). Nas camadas mais pobres da população, as famílias chefiadas por mulheres são em grande parte associadas às situações de vulnerabilidade econômica. A mulher, como único membro adulto do domicílio, é a provedora, além de assumir funções domésticas e o cuidado com os filhos. Atrelado a tudo isso, resta ainda a vinculação delas aos trabalhos mal remunerados em tempo parcial ou intermitente, gerando assim maiores dificuldades para garantir a subsistência da própria família.

A informalidade no trabalho, tanto com patrão quanto sem patrão, é caracterizada pela falta de vínculo com um empregador; portanto, o trabalhador não tem nenhum direito ou benefício trabalhista, conforme Meneguin e Bugari (2008). Esses foram elementos significativos na realidade de grande parte das depoentes na fase inicial da maturidade. $O$ fato de não ter vínculo formal favorece a interpretação, por parte das depoentes, de que não trabalhavam de fato, conforme se pode observar no depoimento de Jurema. 
Não. Aqui não trabalhei em canto nenhum. Lavei foi roupa, só lavá roupa. Ainda trabalhei na casa de família uma vez. Não, duas vez trabalhei na casa de família. [...]. Por mês e por peça aí já lavava pra ganhar dinheiro (Jurema).

Assim como Jurema, pela informalidade de suas atividades laborais, Yara não considerava trabalho vender carvão. Para ela, considera-se trabalho a formalidade dessa atividade. Denota-se essa visão quando afirma que era do lar, conforme destacado mais adiante.

Algumas idosas mencionaram seus processos de inserção no mercado de trabalho formal. Esse dado aproxima-se do relato de Ribeiro e Jesus (2016) quando afirmam que, nos anos 70, observou-se uma expansão da economia, crescente urbanização e ritmo acelerado da industrialização. Essas características configuram um momento de grande crescimento econômico, favorável à incorporação de novos trabalhadores, inclusive do sexo feminino. Entretanto, Brito e Souza (2005) destacam que, nessa ocasião, se deu um crescimento extremamente desequilibrado do ponto de vista espacial e social, posto que se vislumbrou um desenvolvimento mais concentrado nos Estados do Rio de Janeiro e São Paulo. Esse desenvolvimento pontual acentuou os desequilíbrios regionais, uma vez que não conseguia gerar o número de empregos que atendesse ao crescimento da sua força de trabalho. Verifica-se, pelas falas das entrevistadas, que elas foram inseridas no mercado de trabalho formal em momentos anteriores aos anos 1970.

Não. Antes era do lar. Foi em 1958 que comecei a trabalhar na Samaritana [Uma escola de Porto Velho]. Trabalhei um ano e pouco e depois passei a ser inspetora (Yara).

Eu trabalhei desde 58, Maternidade Darci Vargas, 20 anos. Eu trabalhava na portaria. Ai de lá eu fui pra Fundação Nacional de Saúde e de lá me aposentei. Lá eu trabalhava no fax, ali na Fundação (Janaína).

Trabalhava. Eu comecei a trabalhar em 50 em escola. Sempre lecionei. Sempre professora (Tainá).

Ai arranjei [Não conclui]. Trabalhei no Américo Tourinho, meu primeiro emprego. Fui trabalhá lá de merendeira. De lá, eu passei 3 anos 
[Incompreensível] no Carmela [Carmela Dutra, nome de uma escola de Porto Velho], né? Vim, trabalhei no Castelo [Nome de uma escola de Porto Velho]. No Castelo eu trabalhei 30 anos. Só no Castelo que eu ganhei meu filho, né? O meu caçula. Ai vim pra perto, né? Que foi o Castelo Branco. Ó sei que passei 35 anos trabalhando. Não tô nem lembrando da data; mais Meados de 1960. É. Ee eu trabalhei 35 anos (Taynara).

$\mathrm{O}$ auge da inserção dessas mulheres no trabalho formal ocorreu entre as décadas de 1950 e 1960. Entretanto, em período anterior a este (década de 1940), quando Porto Velho (denominado na época de Santo Antônio) foi instituído Município do Território Federal do Guaporé, também observou um aumento na oferta de emprego. Conforme afirma Yara, as vagas eram destinadas àqueles com formação acadêmica e/ou com alguma influência socioeconômica.

Porque na época num quase num tinha emprego. Depois foi que o, o municipio passou a território, aí foi que vieram as... [Não conclui] como se diz os empregos, né? Foram abrindo os empregos e elas iam que o, o emprego era pra quem tinha poder executivo [Aquisitivo], né? E quem tinha estudo [Não completa a frase] (Yara).

Um estudo de Belo (2013) apontou que, no período produtivo das idosas atuais, as lutas das mulheres ainda eram circunscritas a um universo minoritário. Conforme relatos, essa não foi a realidade das mulheres amazônicas investigadas. Ao contrário - das 9 entrevistadas, apenas 3 não precisaram trabalhar na adolescência e na infância -, todas elas em algum momento da vida foram inseridas no mercado de trabalho informal. Algumas delas, a exemplo de Taynara, sequer frequentaram a escola. Outras tiveram seus estudos formais interrompidos ainda na meninice.

Frequentei [Referindo-se à escola]. Mas agora, depois de casada. Quer dizer, estudava assim em casa com quem podia ensinar a gente. A gente estudava, mas não era escola não, porque naquele tempo tinha até por livro, quarto livro, quinto livro. Essas coisas assim (Taynara). 
Apesar de todas as dificuldades enfrentadas por essas mulheres, basicamente oriundas de problemas financeiros e/ou matrimoniais, ainda se podia encontrar a presença de atitudes solidárias. Yara, Tainá e Apuana, além de seus filhos consanguíneos, cada uma delas adotou uma criança; e Taynara oferecia alimentação na comunidade onde morava para aqueles menos favorecidos.

Eu vim trabalhar quando cheguei em São Carlos [Região Ribeirinha da cidade de Porto Velho], sabe? Eu, eu. Toda vida trabalhei assim de ajudá em colégio. Ai, eu morava numa casa grande, um barracão. Ai eu fazia merenda pras crianças, sem ganhar nada trabalhava, trabalhava. [...] Que eu trabalhei lá, trabalhava de graça, só para ajudar o povo. Não ganhava nada (Taynara).

Foi frequente no discurso das idosas, quando se perguntava sobre o lazer delas durante a maturidade, prontamente fazerem referência ao trabalho, comunicando a inexistência de lazer no cotidiano laboral, formal ou informal. Chama a atenção que não se verifica, na fala das idosas, qualquer traço de questionamento relativo ao processo de exclusão ao qual eram submetidas. Relata Silveira (2015) que, somente na década de 1960, eclodiram os grandes movimentos sociais de contestação às diferenças sociais; movimentos contra a subalternidade e exclusão das mulheres do poder, e pela autonomia e direitos delas, nos principais centros urbanos do Brasil e do mundo. Ocorre que, nessa época, as localidades mais longínquas geograficamente, a exemplo da Amazônia e em especial a cidade de Porto Velho, encontravam-se bastante isoladas dos grandes centros do país, portanto, sem acesso aos movimentos sociais e as discussões geradas em torno deles. Assim, o discurso feminista não chegou de forma igual e nem ao mesmo tempo em todas as realidades. Nesse sentido, a dinâmica no cotidiano das mulheres era outra. No caso das depoentes, essa realidade aponta para práticas feministas por necessidade, independente dos movimentos revolucionários que ocorriam nos grandes centros culturais do Brasil e do mundo. Embora parecessem desconhecer os movimentos de consciência de gênero, 
as mulheres não ocuparam o cargo de "rainha do lar", denominação combatida pelas feministas. As conquistas alcançadas no mundo do trabalho e a relativa emancipação não decorriam do fortalecimento do feminismo e/ou de outros movimentos políticos da época, mas de uma necessidade real de sobrevivência e manutenção dos filhos.

Os movimentos sociais de contestação às diferenças sociais entre homens e mulheres apontam que, mesmo em uma época em que o espaço no mercado de trabalho para o gênero feminino era restrito, algumas mulheres transpunham as barreiras do papel de ser apenas esposa, mãe e dona do lar (Silveira, 2015). Ainda que aparentemente sem a influência dos movimentos sociais feministas, as depoentes atuavam como provedoras do lar; em alguns casos sendo elas as únicas provedoras da família, desmistificando o discurso dominante da mulher vulnerável.

Somente em 1985, foi criado o Conselho Nacional dos Direitos da Mulher (CNDM), vinculado ao Ministério da Justiça. E, em 1988, a Constituição que estipulou vários dispositivos que amparam os direitos das mulheres, quando determina que todos são iguais perante a lei, sem distinção de qualquer natureza.

A maioria das depoentes cita que, devido à multiplicidade de atividades laborais que exerciam simultaneamente, para suprir as necessidades de manutenção da família, não tinham tempo para desfrutar de lazer. Essa visão hierarquiza atividades e aponta o lazer como mero acessório do trabalho, conforme citam Alves e Isayama (2006). Lembram também Alves e Marcellino (2010) que o sistema capitalista pode anular as outras dimensões de expressão das pessoas, por enxergar o trabalho como principal ocupação. O lazer acaba sendo entendido como atividade de tempo livre, não séria e vazia (Alves; Marcellino, 2010). Ocorre que, no caso das depoentes menos abastadas economicamente, perante a demasiada carga de trabalho, a anulação do lazer como expressão da vida humana não se dava pelo fato de entenderem o trabalho como principal ocupação, mas, sobretudo, pela falta de energia e tempo para desfrutar de qualquer outra atividade que não fosse relativa à subsistência. 
Depreende-se, na fala das idosas, que a situação socioeconômica foi um elemento importante na definição das suas práticas de lazer e de ausência de lazer. A maioria das idosas era muito pobre. Foram acostumadas ao trabalho pesado, com dupla, tripla ou mais jornada de trabalho; habituadas a lavar as roupas nos rios, carregar lata de água na cabeça; à exceção de Tainá, que era professora e tinha uma vida estável, financeiramente, junto com o marido; e Iracema, que nunca precisou trabalhar. Portanto, as práticas de lazer da maioria dessas mulheres, como não poderiam ser diferentes, reproduziam as desigualdades sociais.

Apesar de a Amazônia apresentar um contexto diferenciado e serem parcos os estudos voltados ao lazer nessa realidade, uma publicação de Bruhns (1997) contribui para a análise dessa questão. Alude o autor que, entre as dificuldades ao acesso do lazer, pelas camadas desfavorecidas, situa-se a necessidade de cumprir horas-extras no trabalho, preços inacessíveis dos ingressos para apreciação de eventos de caráter cultural, além de dependência de transportes coletivos e a longa distância do lar para os centros de lazer. Na realidade das mulheres investigadas, os seus afazeres iam além do cumprimento de horas extras. Se, por um lado, elas não tinham tempo para pensar em lazer, suas atividades iam se naturalizando no cotidiano diante das inúmeras tarefas que desempenhavam para a sobrevivência da família, conforme cita Jurema, que trabalhava para garantir o sustento da família e $o$ atendimento às tarefas do lar.

Com Tainá, oriunda de família com condição econômica satisfatória, se observa a existência de momentos de lazer em família.

Ab! Tinha [Afirmando que tinha lazer]. A gente passeávamos bastante todo domingo. Ele [O marido] pegava o carro, a gente saía é, pra rodar Porto Velho todinha. Ou então ia pra banhos, pra viagens, viajava pra Guajará-Mirim [Município do Estado de Rondônia] (Tainá.)

Mas, conforme visto anteriormente, a realidade de Tainá não é acompanhada pelas demais depoentes. As dificuldades econômicas, aliadas às precárias condições de infraestrutura da cidade, refletem a realidade das 
poucas opções de lazer dessas mulheres, na época da maturidade, na cidade de Porto Velho. Jurema, conforme destacado anteriormente, depõe que não se lembrava de ter usufruído de momentos de lazer, pois sequer tinha tempo para pensar em tais possibilidades, frente aos inúmeros afazeres a exercer. Entretanto, destaca também a inexistência de opções de lazer na localidade.

Dormir. Só. Que não tinha para onde ir, né? [Risos]. Só dormir (Jurema).

Em aparente contradição com os pontos narrados anteriormente, as depoentes fizeram menção a algumas práticas de lazer. Essa provável incoerência é analisada por Sartori (2013). Para a autora, a

Síntese de uma trajetória nem sempre é linear, ou coerente das múltiplas representações. Devemos compreender que os consensos se refazem e desfazem a todo o momento. Ou seja, o que aceitamos anteriormente, podemos negar hoje, e podemos também, difundir atualmente, o que foi renegado no passado. A História é um fluxo contínuo do cotidiano que não cessa, mas que se rompe, se desfaz e se renova a todo instante (p. 97).

Yara e Tainá apontam algumas opções de lazer, entretanto, acessível somente às populações de maior poder aquisitivo, das quais elas não faziam parte. Esse dado acompanha o que foi dito por Marcellino (2000) sobre os condicionantes ou limitadores do lazer. Também encontra eco no que Bruhns (1997) citou sobre os preços inacessíveis dos ingressos para apreciação de eventos como uma das dificuldades ao acesso do lazer, pelas camadas desfavorecidas. Em ambos os casos, o relato diz respeito à barreira socioeconômica, que limita a participação nas práticas de lazer.

Ah, eles tinha a diversões deles. Tinha as festas, né? [Referindo-se a pessoas de classe social mais abastada] Tinha os bailes e quem não num tinha condiçâes não ia pros bailes que eles iam, nera? Que era baile finos, né? Tinha o Bancrévea [Nome de um Clube] aqui perto, mas só era gente, gente fina. Até que um dia [Pausou fazendo suspense]... Aconteceu um, um, um desastre lá dentro que acabou o Bancrévea [Falando baixinho] [...] (Yara.) 
Olha na época tinha cinema. Tinha o Cine Brasil, tinha a Praça Marechal Rondon que era o chique aos Domingos e o povo ia passear na praça (Tainá).

Detalhando o que foi dito anteriormente, segundo Marcellino (2002), existem barreiras classificadas como inter e intraclasses de acesso ao lazer. Essas barreiras são elementos que cooperam para o distanciamento da pessoa adulta do lúdico e estão classificadas em três categorias principais: a) a falta de educação para e pelo lazer; b) a situação socioeconômica; c) a idade. No caso deste trabalho com as idosas, encontra-se identificação direta com a primeira barreira, sendo acrescentada outra, que envolve a questão da falta de oferta de espaços destinados à prática de lazer pelo poder público.

Complementando o que disse Marcellino (2002), um estudo de Alves (2007) sobre práticas de lazer de adultos mostrou que, além da excessiva carga de trabalho, um segundo motivo fundamental que interfere nessa prática é a falta de educação para e pelo lazer. O estudo de Alves (2007) detectou que a falta de tempo não é o principal motivo do afastamento, mas, sim, não saber o que fazer durante um tempo disponível. Conforme já demonstrado anteriormente, esses achados não são compartilhados com os resultados ora apresentados sobre o lazer das mulheres da Amazônia na maturidade.

Taynara cita algumas opções de lazer somente para adultos, mas afirma que preferia usufruir os momentos de não trabalho com os filhos pequenos e demais parentes.

Tinha [Afirmando que existiam espaços de lazer]. Já inventaram o Flamengo [Faz referência ao Clube do Flamengo]. Já tinba o Flamengo, né? O pessoal ia pra lá. Eu, não gostavam. Não gostava de festa não. [...]. Ab! Sim eu passeava. Tinha aquela fonte de água luminosa, em frente o palácio [Palácio do Governo]. Lá levava meus filhinhos pra passear, pra ver. De noite dava tempo. [...]. Eu saía assim, nas casa dos parente que já tinha aqui, né? Em Porto Velho eu ia na casa deles, eles iam na minha (Taynara). 
As praças eram os espaços mais acessíveis para a população mais pobre; oportunizava momentos de passeios com os filhos.

Com uma trajetória de vida de trabalho, Apuanã cita que seus momentos de lazer foram com os filhos já maiores. Estes a incluíam na companhia dos amigos e namoradas.

Às vezes eu ia pra casa dos colegas deles [Dos filhos], namorada dele, ou da mãe delas. Assim, saía enquanto ele era rapaz, né? Mas depois que ele casou, ai a gente já saía pra outros canto com ele (Apuana).

A despeito da precariedade da infraestrutura da cidade, conforme descrito pelas informantes, não existia preocupação com a segurança tal como nos dias atuais. $\mathrm{O}$ destaque dado ao uso das ruas como local de brincadeira contrasta com a realidade de algumas localidades urbanas brasileiras. $\mathrm{Na}$ atualidade, o próprio local de moradia de Yara parece já apresentar alguns impeditivos para o uso da rua como espaço de lazer. Quando diz que antigamente “[...] não tinha esse negócio de ficar trancado. Era todo mundo na rua mesmo correndo [...]", parece fazer referência à violência nas ruas que, atualmente, na maioria das localidades brasileiras, limita a presença das pessoas fora de suas moradias.

As vivências do trabalho árduo são tão fortes nas lembranças das idosas que inicialmente, ao serem questionadas, diziam que não tiveram nenhuma prática de lazer. Possivelmente essa afirmativa se deve às suas parcas experiências lúdicas. Conforme afirma Alves (2007), as possibilidades de vivência do componente lúdico da cultura na vida adulta são restritas. No caso das idosas, é possível que tais restrições tenham impedido de inicialmente se reportarem ao pequeno mundo de lazer ao qual tinham acesso na época da maturidade. Nesse sentido, apesar das precárias condições de infraestrutura da cidade e de o tempo ser gasto prioritariamente nas atividades laborais, fossem no lar ou fora dele, as idosas nomearam os tipos de lazer que vivenciaram. 
A gente [Ela e o marido], só as vez ia pra uma festa, não? Num tinha um clube que era aqui? Até eu esqueci o nome do clube. Que a gente ia. Ele me conbeceu lá nesse Clube dançando. Ali na rua, pera aí que eu não sei nem o nome da rua também. Sei mas não me lembro não. Naquela época já tinha, tinha o Danúbio já. Pois é, mas esse era mais pra cá onde [Não conclui]. Já tinha o Bancreve, mais não era ele não (Jurema).

Ai eu conheci um, uma, uma colega. Ai nós tínhamos uma diversão que a gente ia pra lá pra um negócio dum, como é que se diz [Fala baixinho]. Lá no Celso, do candomblé. Era essa na diversão, a gente ia pra lá e tal assistir ai (Yara).

Eu saía assim, nas casa dos parente que já tinha aqui, né? Em Porto Velho. Eu ia na casa deles; eles iam na minha (Taynara).

O lazer era se juntá os vizinho, sentá na frente e cunversar, contá história. Ai, a gente mandava os menino brincar. Assim, a gente olhando, a gente olhando, enquanto ele [Os filhos] estava brincando, a gente. Ai, quando dava 9 horas, às vezes antes disso. Bora, entra todo mundo, ia dormir (Aracy).

"[Gagueja] É... [Gagueja. Pensando]. Muito difícil, né? [Referindo-se ao lazer]. A não ser assim, às vezes no sítio, um dia de domingo. Não, só isso mermo. Só brincadeira pouca (Janaína).

Despois que eu comecei a conhecer as pessoas eu ia pras festas. Lá, de noite, uma vez no mês, duas vezes. A gente [Não conclui]. Já arrumei as colega, né? Nos trabalhos. [...]. Foi arrumando as colegas. A gente se juntava e ia prasfestas (Apuana).

Ab! Tinha sim [Referindo-se a diversão]. Minha familia sempre foi festeira. Gostava de festa. Meu pai gostava de festa, meu marido tocava no conjunto com Doutor Diogo e nas festas. Nós íamos todo tempo festa. Tinha muito aqui em casa. Todo domingo tinha festa aqui [Risos]. Olha, os vizinhos [Não conclui]. Nós nos reunimos mais na época, na época de São João, e o mês de junho que tinha, isso quando já tinha criança, né? E os vizinhos se reuniam, faziam quadrilha, aqui das crianças (Tainá).

Chama a atenção a ausência, na fala das depoentes, do Estádio Aluízio Ferreira como um espaço de lazer; quer para a prática do esporte, quer para a assistência de espetáculos, mesmo que não frequentado por algumas, a exemplo do cinema e clubes. Esse estádio, localizado na capital do Estado 
de Rondônia, Porto Velho, fora da zona central da cidade, foi construído em 1957 para práticas de futebol, sendo o primeiro espaço público oficial para a prática esportiva. A disponibilidade à sociedade desse espaço de esporte e lazer se deu próximo à década de 1960, momento de grandes reflexões para a sociedade contemporânea, conforme já mencionado anteriormente. Na década de 1950, algumas mulheres já se destacam nos espaços de futebol no Rio de Janeiro. Em 1956, Dulce Rosalina se torna a primeira mulher a liderar a Torcida Organizada do Vasco (Costa, 2017). Anteriormente, na década de 1920, a assistência aos espetáculos de futebol era um luxuoso programa das elites urbanas (Franzini, 2005). Pela ausência da menção do Estádio Aluísio Ferreira, no discurso das depoentes como um espaço de lazer, nota-se um grande distanciamento entre a Amazônia e a região Sudeste (no caso, Rio de Janeiro), no que diz respeito à participação da mulher nos espaços de futebol.

No âmbito esportivo, na Amazônia, parecia-se manter a cultura da mulher como não torcedora ou jogadora de futebol, apesar de, no Brasil, a assistência nos campos de futebol já haver sido um programa social sofisticado na década de 1920, e as mulheres começarem a ter alguma visibilidade na prática desse esporte (Franzini, 2005).

O não registro do Estádio Aluízio Ferreira como espaço de lazer pode expressar, ainda que de modo inconsciente, as relações de gênero presentes na localidade e no cotidiano das mulheres. Cita Franzini (2005) que o universo do futebol caracteriza-se, desde a sua origem, como um espaço eminentemente masculino, entretanto, esse espaço não é apenas esportivo, mas também sociocultural.

O Estádio Aluízio Ferreira era o único espaço público de esporte e lazer disponível em Porto Velho, na época de maturidade das idosas. Entende-se espaço público de lazer o que diz Pedroso e Silva (2011) e Radicchi et al. (2015): os espaços esportivos de lazer e educação referem-se às instalações e equipamentos urbanos destinados à prática de atividades físicas e/ ou esportivas de caráter espontâneo e livre, presentes em área pública. Os autores consideram ainda espaços públicos como locais com algum tipo de infraestrutura esportiva voltada ao lazer, educação ou participação de acesso 
livre pela população e/ou que esteja localizado em instituição pública. As depoentes citam as duas praças localizadas no centro da cidade de Porto Velho, como locais de passeios. A gratuidade facilitava acesso a esses locais, apesar da distância de suas moradias.

As companhias das idosas para as atividades de lazer se dividiam entre família e amigos, sendo o primeiro caso o mais mencionado pelas participantes deste estudo.

O lazer é um fenômeno característico da cultura humana, daí constatar-se que, mesmo diante de todas as adversidades, as idosas, quando na maturidade, tinham suas atividades de lazer. Vislumbra-se nas suas falas alguns aspectos que delineiam os conceitos atuais de lazer. Um deles, conforme cita Camargo (apud Aquino; Martins, 2007), é o sentido popular da palavra, relacionando "lazer" a "tempo livre" ou algum tipo de atividade realizada nos momentos de folga. Com Camargo (1989), entende-se lazer como um conjunto de atividades realizadas num tempo livre subtraído ou conquistado, historicamente, da jornada de trabalho profissional e doméstica, que interferem no desenvolvimento pessoal e social (apud Aquino; Martins, 2007). Complementando o que diz Camargo, citam Gomes, Pinheiro e Lacerda (2010) que o lazer associado simplesmente à palavra "tempo livre" está em consonância com uma visão ultrapassada dessa prática. A partir do que dizem Gomes, Pinheiro e Lacerda (2010), o lazer está entre as esferas da vida humana que representam os fatores básicos para o exercício da cidadania. Considerando esses aspectos, pode-se inferir que parte dessas mulheres teve sua cidadania negada.

É localizada na fala das idosas a negação de que tivessem tempo para usufruir de lazer, utilizando como justificativa os inúmeros afazeres que tinham que realizar. Essa postura acompanha o que cita Camargo (apud Aquino; Martins, 2007), quando diz que o lazer é uma conjunção de ocupações que possuem certas características como a liberação das obrigações, por exemplo. Para as depoentes, o lazer parecia se restringir a passatempos e distrações, benefícios aos quais elas não podiam se dar o luxo de usufruir.

Nesse sentido, as idosas, durante a maturidade, não se consideravam liberadas, em momento algum, de seus afazeres de trabalho, portanto, 
estavam quase sempre impossibilitadas de usufruir o tempo-livre com o lazer. O possível tempo-disponível, fora do trabalho formal e/ou das obrigações, era reutilizado para mais e mais obrigações. O lazer raramente fazia parte do cotidiano dessas mulheres.

As atividades de lazer das idosas na fase de maturidade eram caracterizadas pela inexistência (no caso de Iracema) ou pela descontinuidade da prática e restrição quanto à variedade e quantidade. A descontinuidade realça, na fala das depoentes, quando deixam entender que não era destinado um momento específico para o lazer, pois tinham inúmeras atividades de trabalhos tanto fora como no interior do lar. A restrição quanto à variedade de práticas decorre de deficiência qualitativa e quantitativa na infraestrutura e logística. Prevaleciam locais públicos como praças, balneários, clubes e cinema. Alguns, entretanto, com acessibilidade limitada pelo fato de exigir pagamento ou pela distância das residências das depoentes.

A precarização do lazer, juntamente com a inacessibilidade a direitos sociais básicos, como uma habitação digna ou uma escolarização adequada, constatada neste estudo aproxima-se ao trabalho de Mendonça, Silva, Oliveira e Dantas (2009), sobre o cotidiano de lazer dos moradores do "Santa Rosa”, em Campina Grande, na Paraíba. Esses autores, juntamente com outros (Marcassa, 2004), criticam as políticas sociais brasileiras, dentre elas as do lazer, que se desenvolvem sob a lógica paternalista e assistencialista. Ocorre que as mulheres pobres residentes na região Amazônica, em especial em Porto Velho, no período da maturidade, entre 1957 a 1995, não gozavam de nenhuma política para o setor de lazer e quiçá para nenhum setor social. Entretanto, a Constituição da República Federativa do Brasil de 1988 , em seu artigo $6^{\circ}$, já preconizava que o lazer é um direito social de todo cidadão Brasileiro.

Um estudo de Mori e Silva (2010), confirma os resultados aqui apresentados sobre o lazer de adultos. Segundo os autores, os participantes do estudo tinham uma rotina de trabalho árdua, cujas obrigações permanentes os afastavam do lazer, dificultando a valorização dessas vivências.

Mas essa realidade não se deu em todo o Brasil. O estudo de Possamai, Gastal e Negrine (2009), realizado com idosos residentes na Região da 
Serra Gaúcha/RS, indica que os participantes usufruíram de momentos inesquecíveis de lazer quando estavam na maturidade. Apesar de todas as dificuldades enfrentadas para os deslocamentos nas viagens, a exemplo de total falta de estrutura complementar, como de hospedagem e alimentação, do cotidiano diário de trabalho na roça, relatam o prazer que encontravam nesses momentos descritos como lazer. Foram citadas, como momentos de lazer, as obrigações religiosas, como missa e a presença em rituais sociais como casamentos, funerais e batizados; e, posteriormente, após o casamento, a visita à casa de parentes (pais, sogros, avós). Apesar de se tratar de práticas simples e com pouca variedade, os relatos apresentados pelos autores deixam claro que os momentos de lazer foram importantes no cotidiano daquela população; de modo totalmente distinto das mulheres da Amazônia. As vivências de lazer destas últimas se davam em momentos furtivos, provavelmente ocupando um tempo que deveria ser destinado ao repouso.

\section{Considerações finais}

Este capítulo apresentou estudo sobre as manifestações de lazer de idosas Amazônicas, residentes em Porto Velho durante a maturidade. Dentre as principais características do universo feminino dessas mulheres destaca-se o discurso da sobrevivência por uma condição de sua classe social. Algumas delas adquiriram a cultura e a necessidade do trabalho ainda na infância, passando pela meninice, adolescência e permanecendo na maturidade.

Como não poderia ser diferente, as práticas de lazer das mulheres estudadas têm profunda relação com o contexto social, econômico e cultural no qual estavam inseridas. O lúdico na vida dessas mulheres se caracteriza pela inexistência de lazer (no caso de uma delas) ou pela descontinuidade da prática, e pela restrição quanto à variedade e quantidade. As praças, clubes de festas, cinema e balneários eram os espaços de lazer da localidade. Como nem todos eram espaços públicos ou próximos das residências das depoentes, a aproximação a eles, pela maioria das mulheres, era restrito. $\mathrm{O}$ acesso ao cinema e a alguns clubes estava disponível somente para a 
população com um poder aquisitivo que garantisse o pagamento da entrada. Assim como na atualidade, juntamente com o aspecto econômico, os fatores social e cultural da época também eram condicionadores das vivências de lazer das mulheres. Os grupos de compartilhamento de práticas de lazer das mulheres eram os filhos e amigos.

As idosas não nomearam materiais ou equipamentos que tenham sido utilizados nas suas práticas de lazer na idade adulta. Tal ausência justifica-se pela precariedade de infraestrutura e de logística dos espaços públicos e culturais disponíveis para o lazer, visualizadas na fala das depoentes.

\section{Referências}

ALVES, C. O papel do profissional de Educação Física como intermediário entre o adulto e o lúdico. 2007. Dissertação (Mestrado em Ciências)-Faculdade de Ciências da Saúde. Curso de Educação Física, Unimep. Piracicaba, 2007. Disponível em: <https://www. unimep.br/phpg/bibdig/pdfs/2006/KNRDPSSCUDQB.pdf>. Acesso em: 7 dez. 2017.

ALVES, C; ISAYAMA, H.F. Considerações sobre o lazer na idade adulta. In: MARCELLINO, N, C. Repertório de atividades por fases da vida. Campinas: Papirus, 2006.

ALVES, C; MARCELLINO, N.C. Adulto e lúdico: atuação do profissional de Educação Física no lazer. Motriz, Rio Claro, v.16, n.1, p.103-112, jan./mar., 2010. Disponível em: $<\mathrm{http}: / /$ cev.org.br/biblioteca/adulto-ludico-atuacao-profissional-educacao-fisica-lazer/> . Acesso em: 16 mar. 2018.

AQUINO, C.A.B.; MARTINS, J.C.O. Ócio, lazer e tempo livre na sociedade do consumo e do trabalho. Revista mal-estar e subjetividade, Fortaleza. v.VII, n.2. set.2007. Disponível em: <http://pepsic.bvsalud.org/pdf/malestar/v7n2/13.pdf〉. Acesso em: 2 abr. 2017.

BARDIN, L. Análise de Conteúdo. 4.ed. Lisboa: Edições 70 LDA, 2009.

BELO, I. Velhice e mulher: vulnerabilidades e conquistas. Revista Feminismos. v.1, n.3, set./dez. 2013. Disponível em: <http://www.feminismos.neim.ufba.br/index.php/revista/ article/viewFile/84/82>. Acesso em: 16 dez. 2015.

BRITO, F.; SOUZA, J. Expansão urbana nas grandes metrópoles - o significado das migrações intrametropolitanas e da mobilidade pendular na reprodução da pobreza. São Paulo Perspec, São Paulo, v.19, n.4, São Paulo Out/Dez. 2005. Disponível em: <http://www. scielo.br/scielo.php?script=sci_arttext\&pid=S010288392005000400003>. Acesso em: 27 jul. 2017.

BRUHNS, H.T. Relações entre Educação Física e o lazer. In: BRUHNS, H.T.(Org.). Introdução aos estudos do lazer. Unicamp: Campinas, 1997. 


\section{CAMARGO, L.O.L. O que é lazer. São Paulo: Brasiliense, 1989.}

COSTA, L. As arquibancadas da torcedora. A presença feminina nos estádios brasileiros. Disponível em: <https://blogdojuca.uol.com.br/2016/07/as-arquibancadas-da-torcedora-a-presenca-feminina-nos-estadios-brasileiros/>. Acesso em: 1 set. 2017.

Departamento de Vigilância. Prevenção e controle das ist, do hiv/aids e das hepatites virais. Ministério da Saúde. 2006. Disponível em: <http://www.aids.gov.br/>. Acesso em: 21 dez. 2017.

FRANZINI, F. Futebol é "coisa para macho”? Pequeno esboço para uma história das mulheres no país do futebol. Rev. Bras. Hist. São Paulo, v. 25, n. 50, jul./dez. 2005. Disponível em: <http://www.scielo.br/scielo.php?script=sci_arttext\&pid=S010201882005000200012 >. Acesso em: 1 set. 2017.

GOMES, C.; PINHEIRO, M.; LACERDA, L. Direitos sociais: Questão de acesso e participação. In: Lazer, turismo e inclusão social: intervenção com idosos. Belo Horizonte: UFMG, 2010. Disponível em: <http://www2.esporte.gov.br/arquivos/snelis/esporteLazer/ cedes/lazerTurismoInclusaoSocial.pdf >. Acesso em: 16 ago. 2016.

GORAYEB, A. Território Federal do Guaporé. Coluna do Fundo do Baú. 2015. Disponível em: <http://www.newsrondonia.com.br/noticias/territorio+federal+do+guapore/63083 >. Acesso em: 23 jul. 2017.

KATSURAGAWA, T.H.; SOARES GIL, L.; TADA, M.S.; SILVA, L.H.P. Endemias e epidemias na Amazônia. Malária e doenças emergentes em áreas ribeirinhas do Rio Madeira. Um caso de escola. Estud. Av. v.22, n.64, São Paulo, dez.2008. Disponível em: <http:// www.scielo.br/scielo.php?script=sci_arttext\&pid=S0103-40142008000300008>. Acesso em: 1 set. 2018.

LEANDRO, R.V. Os ciclos ficcionais da borracha e a formação de um memorial literário da Amazônia. Universidade de Brasília. Instituto de Letras. Departamento de Teoria Literária e Literaturas. Programa de Pós-graduação em Literatura. Brasília-DF. 2014. Disponível em: <http://repositorio.unb.br/bitstream/10482/17742/1/2014_RafaelVoigtLeandro.pdf >. Acesso em: 21 jul. 2017.

LEVY,M.S.F. A escolha do cônjuge. Rev.bras. estud.Popul, São Paulo, v.26, n.1,2009. Disponível em: <http://www.scielo.br/scielo.php?pid=S0102-30982009000100009\&script=sci_abstract\&tlng=pt >. Acesso em: 1 out. 2017.

MAMBRINI, V. Costumes, ídolos e desafios da mulher de 1930. Revista eletrônica Ú1timo Segundo, São Paulo, 2010. Disponível em: <http://ultimosegundo.ig.com.br/revolucao1930/costumes-idolos-e-desafios-da-mulher-de-1930/n1237772885629.html >. Acesso em: 28 jul. 2017.

MARCASSA, L. Lazer - Educação. In: Dicionário crítico do lazer. (Org.) GOMES, C.L. Belo Horizonte: Autêntica, 2004.

MARCASSA, L. Lazer e Humanizacão. Campinas: Papirus, 1993. 
MARCASSA, L. O conceito de lazer nas concepções da Educação Física Escolar: o dito e o não dito. Congresso de Educação Física e Ciências do Desporto dos Países de Língua Portuguesa, 8. 2000. Disponível em: <https://ufsj.edu.br/portalrepositorio/File/dcefs/ Prof._Adalberto_Santos2/13o_conceito_de_lazer_nas_concepcoes_da_ef_escolaro_dito_e_o_nao_dito10.pdf >.Acesso em: $20 \mathrm{dez} .2017$.

MARCASSA, L. Estudos do lazer: uma introdução. 3. ed. Campinas: autores associados, 2002 .

MARTINS. W.H. Capricho do absurdo. A morte prematura da República Socialista do Guaporé. SECEL. Porto Velho: Graffporto, 2012.

MENDONÇA, L.C.P.; SILVA, E.A.P.C.; OLIVEIRA, N.S.; DANTAS, E.R. Pelo direito ao lazer: participação e mobilização social no bairro do Santa Rosa. Campina Grande: EDUEPB, 2009.

MENEGUIN, F.B.; BUGARI, M.S. A informalidade no mercado de trabalho e o impacto das instituições: uma análise sob a ótica da teoria dos jogos. Econ. Apl. Ribeirão Preto, v.12, n.3, 2008. Disponível em: <http://www.scielo.br/scielo.php?script=sci_arttext\&pid=S141380502008000300001>. Acesso em: 27 jul. 2017.

MORI, G; SILVA, L.F. Lazer na terceira idade: desenvolvimento humano e qualidade de vida. Motriz, Rio Claro, v.16, n.4, 2010. Disponível em: <http://www.scielo.br/pdf/motriz/ v16n4/a15v16n4.pdf>. Acesso em: 20 dez. 2017.

MOURA, G.A.; SOUZA, L.K. Práticas de lazer de idosos institucionalizados. Rev. Movimento, Porto Alegre, v. 19, n. 4, 2013. Disponível em: <http://www.seer.ufrgs.br/Movimento/article/viewFile/36131/27445>. Acesso em: 16 dez. 2015.

OLIVEIRA, M.K. Ciclos de vida: algumas questões sobre a psicologia do adulto. Universidade de São Paulo. Revista Faculdade de Educação. 2004. Disponível em: <http://www. revistas.usp.br/ep/article/view/27931 >. Acesso em: 7 jun. 2017.

PEDROSO, C.A.M.Q.; SILVA, F.F.P. Equipamentos de esporte e lazer na cidade: planejamento dos parques urbanos do Recife, PE, Brasil. EFDeportes.com, Revista Digital. Año 16. n. 158. Buenos Aires, 2011. Disponível em: <http://www.efdeportes.com/efd158/equipamentos-de-esporte-elazernacidade.html >. Acesso em: 27 jul. 2017.

PERROT, M. Práticas da memória feminina. Revista Brasileira de História, v. 9, n. 18, 1989. Disponível em: <https://pt.scribd.com/document/342175226/PERROTMichellePraticasDaMemoria-Feminina>. Acesso em: 2 set. 2017.

PONTES, C.A.A.; SHAMM, F.R. Bioética da proteção e papel do Estado: problemas morais no acesso desigual à água potável. Cad. Saúde Pública, Rio de Janeiro, v.20, n.5, 2004. Disponível em: <http://www.scielo.br/pdf/\%0D/csp/v20n5/26.pdf>. Acesso em: 27 jul.2017.

PORTAL DA AMAZÔNIA. Borracha: apogeu e decadência. Disponível em: <http:// portalamazonia.com.br/secao/amazoniadeaz/interna.php?id=114>. Acesso em: 20 jul. 2017 
POSSAMAI, A. M.; GASTAL, S.; NEGRINE, A. A viagem na memória do idoso. Anais da Associação Brasileira de Pesquisa e Pós-graduação, 2009. Disponível em: <https:// www.anptur.org.br/anais/anais/files/6/56.pdf >. Acesso em: 1 ago. 2017.

RADICCHI, M.R.; SANTOS, J.B.; CARNEIRO, D.S.; ANSELMO, J.G.; REIS JÚNIOR, M.F. Descrição dos espaços esportivos de lazer e educação na cidade de Parintins, Amazonas. Rev. Bras. Ativ. Fis. Saúde, Pelotas/RS, v.20, n.6, p.626-628. 2015. Disponível em: <https://periodicos.ufpel.edu.br/ojs2/index.php/RBAFS/article/view/5898/5244>. Acesso em: 18 ago. 2016.

RIBEIRO; R.M.; JESUS, R.S. A inserção da mulher no mercado de trabalho no Brasil. Revista de Ciências Humanas, Viçosa, v. 16, n. 1, p. 42-56, jan/jun. 2016. Disponível em: < http://www.cch.ufv.br/revista/pdfs/vol16/artigo3dvol16-1.pdf >. Acesso em: 1 ago. 2017.

SARTORI, J. Memória de idosos. Sem Aspas, Araraquara, v. 2, n.1, 2, 2013. Disponível em: <file://C:/Users/User/Downloads/Dialnet-MemoriaDeIdosos-6263032\%20(1).pdf>. Acesso em: 30 nov. 2017.

SILVEIRA, R.M.G. Diversidade de gênero: mulheres. Disponível em: <http://www.dhnet.org.br/dados/cursos/edh/redh/03/03_rosa1_diversidade_genero.pdf $>$. Acesso em: 16 dez. 2015.

SOUSA, R.G. Movimento Feminista. As Mulheres na História. In: Mundo educação. Disponível em: <http://mundoeducacao.bol.uol.com.br/historiageral/movimento-feminista. htm>. Acesso em: 1 set. 2017.

SPINDOLA, G. Trajetória do Poder da Mulher: do lar ao mercado de Trabalho. Curso de especialização em Gestão de equipe. In: Educação, Carreiras e Tecnologia. 2011. Disponível em: <https://pt.slideshare.net/eudelucy/a-trajetria-do-poder-da-mulher-do-larao-mercado-de-trabalho $>$. Acesso em: 28 jul. 2017. 



\section{MANIFESTAÇÕES DE LAZER DE IDOSAS DE PORTO VELHO}

Ivete de Aquino Freire Ramón Núñez Cárdenas

\section{Introdução}

O significado da palavra "idoso/idosa" vem sendo construído ao longo de décadas. Atualmente é temática de interesse de inúmeras áreas de conhecimentos o que contribui para a compreensão e ampliação desse conceito. Por tratar-se de um fenômeno complexo e variável, os estudos mais abrangentes são realizados de uma perspectiva inter e multidisciplinar.

Historicamente a ciência inaugura o primeiro conceito de velhice a partir da ideologia do evolucionismo, fundando a transformação humana em processos biológicos (fases de desenvolvimento humano) como o nascer, crescer, reproduzir-se, envelhecer e morrer (Birman apud Ploner, Michels, Oliveira; Strey, 2017). Com o avançar da idade, inúmeras transformações fisiológicas e morfológicas ocorrem no organismo humano. Apesar desse aspecto, os paradigmas biológicos e cronológicos são insuficientes para a delimitação da condição de velho.

De modo geral, a velhice traz consigo modificações corporais e mentais que marcam essa etapa do processo de desenvolvimento humano. Dentre as principais transformações destacam-se a redução da massa óssea e outras alterações que resultam na degenerescência física, a pele fica mais fina e friável, menos elástica, mais flácida e com menos oleosidade; a visão também declina, principalmente para objetos próximos; a audição diminui e ocorre uma perda de neurônios (Costa; Pereira apud Schneider; Irigaray 2008); surgem as rugas e cabelos brancos, além de outras mudanças naturais. 
Com o avançar da ciência, além do aspecto biológico, o paradigma socioeconômico torna-se também um dos principais elementos para a composição do conceito de idoso. Segundo Ploner, Michels, Oliveira e Strey (2017), no paradigma econômico, o indivíduo tem um valor na sociedade vinculado a sua utilidade no sistema econômico. Acredita-se que o velho está em fase de degeneração, sem condições de continuar produzindo riquezas; portanto, perdeu o seu valor social. Assim, de acordo com Peixoto (apud Ploner, Michels, Oliveira; Strey, 2017), a representação social da velhice está associada a atributos negativos como a decadência e a inutilidade.

Schneider e Irigaray (2008), orientados por diversos autores, compreendem a velhice com base na inter-relação que se estabelece entre os aspectos biológicos, psicológicos, sociais e culturais. Os aspectos psicológicos envolvem dois sentidos. Um deles se refere à relação que existe entre a idade cronológica e as capacidades psicológicas, tais como percepção, aprendizagem e memória, as quais prenunciam o potencial de funcionamento futuro do indivíduo. Outra percepção de idade psicológica tem relação com a visão subjetiva de idade. Esse conceito depende de como cada pessoa avalia e compara a presença ou a ausência de marcadores biológicos, sociais e psicológicos do envelhecimento entre indivíduos da mesma idade (Neri apud Schneider; Irigaray, 2008).

Já os aspectos sociais são orientados pelos hábitos e status social do indivíduo, bem como pelos diferentes papéis sociais ou expectativas que exerce em sua cultura e em seu grupo social (Schneider; Irigaray, 2008). Com o envelhecimento, ocorre uma mudança de papéis sociais, sendo esperado dos idosos comportamentos que correspondam ao que é determinado para eles (Schroots; Birren apud Schneider; Irigaray, 2008). Com a aposentadoria, que chega nessa fase ou próxima a ela, o indivíduo abandona o mercado de trabalho e deixa de ser economicamente ativo. No que tange aos aspectos culturais, a experiência de envelhecimento e velhice varia historicamente de acordo com a sociedade, que demarca, em cada época, critérios para agrupar categorias etárias (Pont Geis, 2003; Neri; Freire apud Schneider; Irigaray, 2008; Mori; Silva, 2010). 
Segundo Pont Geis (2003) e Mori e Silva (2010), essa fase da vida é marcada por preconceitos, estigmas e desvalorização familiar e social, dado o decréscimo da vida produtiva, ligada ao trabalho. Assim, os idosos, se não tiverem uma aceitação em relação à chegada da aposentadoria e problemas decorrentes da idade, poderão viver uma fase de dificuldades de ordem física, social e psíquica.

A atenção inter e multidisciplinar, que orienta os trabalhos mais importantes sobre os idosos, mostra que vem aumentando o número de indivíduos nessa faixa etária, no Brasil e no mundo. De acordo com Ploner, Michels, Oliveira e Strey (2017), entre os principais fatores, destacam-se a "transição epidemiológica", com o suporte do avanço das tecnologias na área da saúde, formas de tratamento e prevenção das doenças, grande controle das doenças infectocontagiosas e parasitárias, aliadas ao aprimoramento das condições sociais e econômicas. Desse modo, a visão do envelhecimento como uma fase biológica é superada por uma nova fase de vida, com diferenças socioculturais, físicas, fisiológicas e morfológicas.

Entende-se que, com o avançar da idade e a conquista da aposentadoria, o idoso adquire maior quantidade de tempo livre, portanto, tem maior oportunidade para desfrutar os benefícios da vida que lhes foram privados durante a maturidade. Dentre as inúmeras possibilidades de atividades a serem usufruídas, encontram-se as práticas de lazer.

As vivências de lazer tem relevância especial para a pessoa idosa. Constituem-se em oportunidade para se expressar, sentir prazer, utilizar a criatividade para se divertir e se desenvolver, agregando sujeitos com desejos e necessidades semelhantes, num mesmo ambiente (Bramante apud Mori; Silva, 2010). Dançar, ouvir música, rezar, fazer ginástica e passear são atividades que trazem muito prazer, promovem vida, já que envolve interação social, sair de uma posição passiva, atuar no mundo, agir (Ploner; Michels; Oliveira; Strey, 2017).

Citam Moura e Souza (2013) que o lazer é uma atividade que diminui na fase adulta e aumenta na velhice. Acrescentam Mori e Silva (2010) que o maior usufruto dessa atividade, nessa etapa da vida, decorre em 
muitos casos da aposentadoria, que brinda o individuo com maior tempo livre além da disponibilidade de recursos econômicos para tais vivências.

Em torno de uma década atrás, Bruhns (1997) já destacava que no Brasil o decréscimo no salário dos aposentados inviabiliza a manutenção do mesmo nível/patamar que tinham quando em fase produtiva. $\mathrm{E}$, antes de Bruhns, Dumazedier (1994) também já alertava que, no contexto brasileiro, por necessidade de sobrevivência, muitas pessoas idosas ainda desempenham algum tipo de atividade que gere renda.

Há consenso na literatura que as práticas de lazer estão condicionadas a fatores tais como faixa etária, nível socioeconômico, cultura, religião, entre outros aspectos. Assim, pessoas desfavorecidas economicamente têm menos oportunidade de lazer do que aquelas mais abastadas. Igualmente discrepante se dá o lazer segundo a faixa etária e a cultura, entre outros aspectos.

Com base na literatura científica que compreende o lazer como um fenômeno com dimensões psicológicas, sociais, econômicas e voltadas para a saúde, entre outras, pretende-se, neste capítulo, descrever as práticas de lazer das idosas integrantes do grupo de convivência denominado "Pioneiras de Rondônia”.

\section{A trajetória de vida como delineamento metodológico}

Conforme já comunicado no Capítulo 2 desta obra, apesar de a idade não ser a melhor medida para a classificação e seleção de indivíduos, neste trabalho foi considerado esse parâmetro pela simplicidade para a obtenção de informações sobre uma pessoa e pela facilidade do seu uso na estratificação das distintas fases da vida de uma pessoa. Este parâmetro facilita o relato da trajetória de vida das idosas, conforme proposto no trabalho. A Figura 1 ilustra o ano de nascimento das depoentes e o ano em que elas passaram a ser consideradas idosas. 
Figura 1 - Demonstrativo do quantitativo de idosas, período em que nasceram e passaram a ser inseridas na categoria "idosas"

\begin{tabular}{|c|c|c|c|c|c|}
\hline $\begin{array}{c}\text { Ano de } \\
\text { Nascimento }\end{array}$ & 1928 & 1930 & 1931 & 1934 & 1937 \\
\hline $\begin{array}{c}\text { Quantitativo de } \\
\text { Idosas }\end{array}$ & 1 & 3 & 1 & 2 & 2 \\
\hline $\begin{array}{c}\text { Idosas: a partir de } \\
60 \text { anos }\end{array}$ & $\begin{array}{c}\text { a partir } \\
\text { de 1987 }\end{array}$ & $\begin{array}{c}\text { a partir } \\
\text { de 1989 }\end{array}$ & $\begin{array}{c}\text { a partir } \\
\text { de 1990 }\end{array}$ & $\begin{array}{c}\text { a partir } \\
\text { de 1993 }\end{array}$ & $\begin{array}{c}\text { a partir } \\
\text { de 1996 }\end{array}$ \\
\hline
\end{tabular}

No ano de 2016, quando foram coletados os dados, as idosas que participaram da pesquisa tinham idade entre 79 e 88 anos. A Figura 2 apresenta uma síntese da trajetória de vida das depoentes.

Todas as depoentes são viúvas, tiveram filhos e possuem netos; algumas delas, bisnetos.

Figura 2 - Síntese da trajetória de vida das participantes da pesquisa

\begin{tabular}{|c|l|}
\hline Identificação & \multicolumn{1}{c|}{ Breve histórico } \\
\hline Iracema & $\begin{array}{l}\text { Com 5 anos foi dada pelos pais em adoção a uma família Turca } \\
\text { que residia no Brasil. Desde então não teve mais contato com a } \\
\text { família consanguínea. Estudou durante 2 anos em ensino infor- } \\
\text { mal com uma professora que a atendia em sua residência. Casou } \\
\text { com } 20 \text { anos; teve 13 filhos, um deles faleceu ao nascer. Durante } \\
\text { toda a maturidade se dedicou a cuidar da casa, dos filhos e do } \\
\text { marido. Afirmou que nunca teve momentos de lazer. }\end{array}$ \\
\hline Yara & $\begin{array}{l}\text { Não conheceu os pais e nem avós. Na infância morou com uma } \\
\text { tia. Na adolescência, por decisão judicial, morou inicialmente } \\
\text { com uma família de desconhecidos e pouco tempo depois foi } \\
\text { destinada para outra. Na residência era responsável pelos traba- } \\
\text { lhos domésticos e cuidava das duas crianças do casal. Frequentou } \\
\text { as primeiras séries escolares quando morava com a primeira } \\
\text { família à qual foi destinada. Teve poucos momentos de lazer na } \\
\text { infância e adolescência. Casou aos 18 anos; teve 5 filhos, adotou } \\
\text { mais 1; Um deles faleceu na infância. Com o marido traba- } \\
\text { lhava na compra e venda de carvão. Abandonada pelo cônjuje } \\
\text { com os filhos menores de idade, Yara trabalhou muito tempo no } \\
\text { mercado informal em serviços de limpeza e lavagem de roupa. } \\
\text { Posteriormente inseriu-se no mercado formal na condição de } \\
\text { faxineira em uma escola, mas manteve os labores informais. }\end{array}$ \\
\hline
\end{tabular}




\begin{tabular}{|c|c|}
\hline Identificação & Breve histórico \\
\hline Jurema & $\begin{array}{l}\text { Não conheceu seus pais e nem avós. Na primeira infância morou } \\
\text { com uma irmã e mais tarde com uma família de desconheci- } \\
\text { dos. Ainda criança era responsável pelos trabalhos domésticos } \\
\text { em troca de casa, comida e roupa. Nunca frequentou a escola. } \\
\text { Foi mãe solteira aos } 16 \text { anos; posteriormente teve um compa- } \\
\text { nheiro com o qual pariu mais } 2 \text { filhos, totalizando } 3 \text {. Dividia seu } \\
\text { tempo entre os labores do lar e diversos trabalhos sem vínculo } \\
\text { formal: trabalho na roça, em casa de fazer farinha, como lava- } \\
\text { deira e como empregada doméstica, vendedora em um pequeno } \\
\text { comércio de rua (bar). Após o falecimento do seu primeiro } \\
\text { companheiro, Jurema casou-se novamente aos } 51 \text { anos, quando } \\
\text { passou a usufruir de alguns momentos de lazer. }\end{array}$ \\
\hline Tainá & $\begin{array}{l}\text { Sempre morou com os pais e frequentou a escola com regulari- } \\
\text { dade. Teve acesso ao lazer, cuidados e afeto por parte dos pais. } \\
\text { Após a conclusão do ensino ginasial, alcançou formação peda- } \\
\text { gógica intensiva para atuar como professora. Casou com } 28 \text { anos. } \\
\text { Pariu } 6 \text { filhos e adotou mais 1, totalizando } 7 \text { filhos. Inseriu-se no } \\
\text { mercado de trabalho em } 1950 \text { como professora. Enquanto tra- } \\
\text { balhava, os filhos e a casa ficavam aos cuidados da mãe e de uma } \\
\text { "moça" que morava com a família. Em toda sua trajetória de vida } \\
\text { desfrutou de práticas de lazer. }\end{array}$ \\
\hline Apuana & $\begin{array}{l}\text { Filha de mãe solteira, a partir dos } 7 \text { anos passou pela casa de } \\
\text { várias famílias para trabalhar. Antes disso já ajudava a mãe no } \\
\text { roçado. Junto das famílias que a recebiam, Apuana era responsá- } \\
\text { vel pelos trabalhos domésticos em troca de casa, comida e roupa. } \\
\text { Tinha alguns momentos em que brincava. Permaneceu com essa } \\
\text { rotina de vida até casar-se. Teve escassas vivências de lazer com } \\
\text { brinquedos feitos de materiais da natureza. Começou a frequen- } \\
\text { tar a escola com } 50 \text { anos de idade. Casou com } 22 \text { anos; pariu } 1 \\
\text { filho e adotou 1; criou os } 2 \text { filhos. Separou-se (fugiu) do marido } \\
\text { porque quis matá-la e ficar com o filho. Dividia seu tempo } \\
\text { entre os labores domésticos e trabalho no roçado. Também fazia } \\
\text { e vendia bolo em lugares que havia festas; chegou a trabalhar } \\
\text { como faxineira e arrumadeira em um prostíbulo; posteriormente } \\
\text { abriu um bar nesse local. Depois, foi trabalhar em uma fábrica } \\
\text { de tecelagem à noite. Durante o dia trabalhava como lavadeira. } \\
\text { O filho mais velho colhia goiabas para vender na rua. Com esse } \\
\text { dinheiro ia ao cinema ou comprava revistas. Posteriormente, } \\
\text { viveu um tempo com outro companheiro, separando-se alguns } \\
\text { anos depois. Inseriu-se no mercado de trabalho formal aos } 30 \\
\text { anos, como zeladora. }\end{array}$ \\
\hline
\end{tabular}




\begin{tabular}{|c|c|}
\hline Identificação & Breve histórico \\
\hline Aracy & $\begin{array}{l}\text { Órfã de pai. Foi criada com a mãe e o padrasto. Teve quatro irmãos } \\
\text { do primeiro casamento da mãe e oito de segundo matrimônio. } \\
\text { Dos } 12 \text { irmãos somente sete chegaram à fase adulta. Desde } \\
\text { criança Aracy já ajudava no trabalho da família que consistia } \\
\text { em costurar chapéu de palha de Carnaúba. Tinha um tempo aos } \\
\text { domingos para brincar. Estudou até a } 4^{a} \text { série primária em uma } \\
\text { escola informal na paróquia da igreja; nessa época tinha } 15 \text { anos. } \\
\text { Casou aos } 16 \text { anos e teve sete filhos. O marido saia à noite para } \\
\text { divertir-se e a deixava em casa. Conseguiu um trabalho aos } 18 \\
\text { anos, mas o marido não permitia que ela trabalhasse. Com seis } \\
\text { anos de casada, ficou viúva e passou dificuldades com os filhos, } \\
\text { baixando o padrão de vida que tinham. Demorou cinco meses } \\
\text { para começar a receber a pensão do falecido marido, que não era } \\
\text { suficiente para o sustento da família. Trabalhou como lavadeira } \\
\text { e empregada doméstica em várias residências. Ainda menores, } \\
\text { os filhos estudavam e trabalhavam para ajudar nas despesas da } \\
\text { casa. Após } 14 \text { anos de viúva, casou-se novamente e teve mais três } \\
\text { filhos, totalizando } 10 \text { fillos paridos. }\end{array}$ \\
\hline Anahi & $\begin{array}{l}\text { Foi criada com os pais e } 11 \text { irmãos. O pai era funcionário (gerente) } \\
\text { de um comércio no qual vendia borracha (látex), café, Castanha } \\
\text { do Pará e peixe. Estudou as séries iniciais no Colégio das Freiras, } \\
\text { mas teve os estudos interrompidos pela grande distância entre } \\
\text { sua residência e a escola. Ajudava a mãe nas tarefas domésticas. } \\
\text { Tinha permissão para brincar com os irmãos e vizinhos, mas } \\
\text { tudo com muito controle de tempo. Teve bons momentos de } \\
\text { lazer em família. Casou com } 16 \text { anos e teve } 13 \text { filhos. Viúva, } \\
\text { veio para Porto Velho para que os filhos tivessem acesso à escola. } \\
\text { Trabalhou como empregada doméstica e na empresa da mesma } \\
\text { família para sustentar os filhos. Posteriormente, trabalhou na } \\
\text { Companhia de Aguas e Esgotos de Rondônia/CAERD, até se } \\
\text { aposentar. }\end{array}$ \\
\hline Janaina & $\begin{array}{l}\text { Órfã de pai. Foi criada pela mãe. Cursou apenas as séries iniciais } \\
\text { do ensino primário no Colégio Maria Auxiliadora. A mãe era } \\
\text { costureira e Janaina, na adolescência, precisava ajudar nas tarefas } \\
\text { domésticas e no trabalho de costura. Tinha alguns momentos } \\
\text { de lazer. Casou com } 18 \text { anos; teve } 10 \text { filhos: três filhos com o } \\
\text { primeiro marido que faleceu e sete com o segundo, que também } \\
\text { faleceu, estando ainda os filhos menores de idade. Inseriu-se no } \\
\text { mercado de trabalho formal aos } 58 \text { anos, trabalhando na porta- } \\
\text { ria da única Maternidade de Porto Velho. }\end{array}$ \\
\hline
\end{tabular}




\begin{tabular}{|c|l|}
\hline Identificação & \multicolumn{1}{c|}{ Breve histórico } \\
\hline \multirow{1}{*}{ Taynara } & $\begin{array}{l}\text { Foi criada com a mãe e o companheiro da mãe. Teve 4 irmãos e } \\
\text { os mimos de filha caçula. Não frequentou a escola. Enquanto os } \\
\text { pais iam para a roça,juntamente com os irmãos cuidava dos afa- } \\
\text { zeres domésticos. Viajava de barco com o padrasto e desfrutava } \\
\text { de passeios nas praias de rio. Teve uma educação rigorosa, mas } \\
\text { com acesso ao lazer. Criava brinquedos com elementos da natu- } \\
\text { reza. Depois de casada teve acesso à escolaridade, em casa, com } \\
\text { pessoas que ensinavam. Casou com 21 anos; teve oito filhos. Um } \\
\text { deles faleceu na infância. No interior onde morava, trabalhava } \\
\text { como merendeira voluntária em uma escola. Quando a famí- } \\
\text { lia veio morar em Porto Velho, fazia e vendia doces e salgados } \\
\text { (lanches em geral) para ajudar o marido nas despesas da casa. } \\
\text { Na década de 1960, começou a trabalhar como merendeira em } \\
\text { uma escola até se aposentar. Conta que seu lazer era ver os filhos } \\
\text { brincarem. }\end{array}$ \\
\hline
\end{tabular}

\section{O lazer na vida das idosas da Amazônia}

Conforme explicitado de modo resumido na Figura 2, a maioria das idosas participantes deste estudo teve uma vida árdua, de muito trabalho, iniciado na infância e na meninice, permanecendo na adolescência e na maturidade. Sobre essa temática, Belo (2013) destaca que a atual geração de mulheres idosas, em sua maioria e em todas as classes sociais, exerceu, ao longo da vida, o trabalho doméstico não remunerado. A realidade estudada não acompanha na totalidade o que foi apontado por Belo, já que três das nove depoentes não trabalharam como empregadas domésticas; duas eram de famílias abastadas economicamente e não passaram nenhum tipo de privação. Portanto, o trabalho doméstico, remunerado ou não, não era uma realidade de todas as classes sociais, conforme afirma o autor.

Com essa história de vida, as mulheres deste estudo chegaram até a terceira idade. Modificações biológicas decorrentes do processo de envelhecimento são reveladas no encontro com essas guardiãs do passado, conforme afirma Bosi (1979). As rugas, os cabelos brancos, a tranquilidade ao falar e a lentidão ao caminhar são as demonstrações mais evidentes dessas modificações biológicas e dos ciclos de vida superados. 
Dentre as depoentes, sete são aposentadas e apenas Jurema e Iracema não recebem esse benefício; ambas recebem pensão dos maridos falecidos. O baixíssimo nível de escolaridade (à exceção de Tainá que concluiu os estudos e obteve a profissão de professora) não foi impedimento para que essas mulheres se colocassem no mercado de trabalho durante a maturidade e conquistassem a tão esperada aposentadoria. As funções são predominantemente de faxineira e merendeira.

Aposentei em 89. Foi o ano em que a [Cita o nome de uma das netas] nasceu (Yara).

70. Eu me aposentei. Foi. Agora em 2004. Tô com 12 anos aposentada. Eu tenho diploma da melhor merendera, funcionária do ano. Tá aí, tudo minhas coisas (Taynara).

Foi pela idade minha. Não foi pelo tempo de serviço. Não. Já eu, me aposentei em noventa. Foi em noventa (Anahi).

Olha, eu tô com [Pausa]. Eu já eu me aposentei com 70 anos e trabalhei 35 anos (Janaina).

[...] Faz [Pensando]. Eu me aposentei em 90 [...]. Pediu pra, pra sair. [Risos]. Me aposentar. Eu me aposentei como professora do antigo Território em 81. Ai, o Valdir era o pró-reitor Acadêmico da Unir (Universidade Federal de Rondônia). Estava passando a Fundacentro pra Unir e o Valdir veio aqui me convidar para ir organizar a secretaria da Unir, porque estava recebendo toda a papelada da Fundacentro. E eu fui. Fiquei de 83 a 90 na Unir da secretaria. Ai, lá, eu tinha duas turmas e preenchia todos os diplomas, registrava no livro, encaminhava pra, pro MEC ou pra secretaria de acordo com o curso, né? Pra secretaria de vinda (Tainá).

Eu tinha 62 anos quando eu saí. Faz tempo. Tô com 79. Aí lá, comecei a trabalhar como zeladora, passei pra copa, foi como copeira. Foi como copeira de gabinete. Depois, eu foi como telefonista; depois eu foi de como [Pausa] trabalhar em protocolo do secretário; depois eu trabalhei em protocolo geral. Aifoi subindo, mas me aposentei como faxinera (Apuana).

Apuana fala do baixo provento da aposentadoria e das estratégias para administrar o salário mínimo que recebe a partir desta condição. 
É... [Pensando] com a minha aposentadoria, aluguel da minha casa, que aposentadoria é um salário minimo. O aluguel da casa também. Aí, a aposentadoria eu pago a [Cita o nome do Plano de Saúde]. Compro alguns remédios porque eu tomo muito medicamento. Agora, graças a Deus tô diminuindo; já não tomo aquela quantidade demais. Então vai dando pra eu ir levando (Apuana).

Esse dado acompanha o que citam Ploner, Michels, Oliveira e Strey (2017) sobre as desigualdades socioeconômicas na velhice. Segundo os autores, as camadas populares, além de experiências, acumulam carências e, na velhice, sua renda não é compatível com as suas necessidades de cuidados com a saúde. Já as camadas superiores conseguem suprir com facilidade as demandas para a manutenção da saúde e de momentos de lazer, a exemplo das viagens.

Igualmente ao atendimento às necessidades de atenção à saúde, as despesas da casa também exigem algumas manobras. Às vezes, recorrem à ajuda dos filhos.

As vezes quando ele pode ele ajuda [O filho]. Compro tudo pra mim, quando tudo dá. Ai quando tá em falta eu falo e ele me dá. Quando tá dando bem [A loja do filho]. Porque agora com essa crise que tá geral no mundo todo, né? Ai tá meio enrolado mais ele sempre tá me dando (Apuana).

É eu mermo [Que paga as viagens]. Tudo é eu. Só quando aperreia um pouquinho eu vou pedir de quem tem. Eu que pago mermo (Janaina).

Minha despesas de casa tudo é eu. Mas os meus filhos também são muito bom e me ajudam. Quando precisa para viajar porque eu ganho a mesada do meu marido e a minha. Eu [Não conclui]. Não se preocupa com isso não (Taynara).

Mas nem todas podem contar com o subsídio dos filhos. É o caso de Anahi, que aos 88 anos tem um filho doente, que depende financeiramente dela, e também de todos os cuidados.

Sou eu que pago [As viagens]. Porque meu filho é doente, né? Eu moro com meu filho. É. Ele tá doente. Agora perdeu a visão dele (Anahi). 
Como resposta do processo de degeneração natural, as idosas já não conseguem mais atender, na sua plenitude, as exigências dos afazeres domésticos das suas residências, o que, na mocidade, fazia parte do cotidiano dessas mulheres. Depois de toda uma vida de trabalho, algumas já não alcançam mais realizar os trabalhos domésticos.

É uma moça que eu pago. [Afirmando que já não realiza nenhum trabalho doméstico]. Não, né? Porque dói minhas [Não completa a frase]. Se eu fizer, né? Nunca gostei. Só cozinhar. Essas coisa eu que faço. Mas limpeza eu não gosto não. Não é que não gosta, porque eu me sinto mal, sabe? Lavá roupa, passá, roupa é tudo a moça que me ajuda. É, ajuda. Minba roupa não é de passá. Tudo é essas ropinha assim. Ela lava tudo (Taynara).

Jurema conta com a empregada doméstica da filha para os cuidados de limpeza da sua casa e preparação de alimentos.

Tem a menina que trabalha por conta da minha filha. Minha filha que paga pra ela. Então ela mora comigo, né? E ela que toma conta negócio, negócio de limpeza essas coisas, lavá roupa. Eu faço mermo [Não conclui]. Nem a comida eu não tô fazendo mais, que é ela que cozinha agora. Eu faço só mermo só o dim dim, doce que eu gosto de fazer quando tem de quê. Eu gosto muito de fazer doce, eu faço doce (Jurema).

Eu mando limpá. Tem uma senhora lá do SESC que ela limpa pra mim. Ela só faz a limpeza da casa mermo. Duns móveis, das coisa. A comida é eu, e de tarde eu passo a tarde pra lá, né? [Para o SESC]. A casa fica fechada. A mulher que lava pra minha filha, ela lava também [Não conclui]. Mas pra mim só é toalha e lençol que minhas roupa quase não tem sujo (Janaina).

Mas essa realidade não é compartilhada por todas as idosas. É o caso de Apuana que, aos 84 anos, ainda cuida dos trabalhos domésticos na sua casa. Constata-se total adaptação a essa realidade de tarefas domésticas, não sendo vista como um fardo, apesar da idade.

Moro, moro sozinha na minha casa, mais sendo numa chácara, junto com meu filho. Ele tem a casa dele e eu moro na outra, na minha só. Sou eu que 
cuido da casa. [...]. Eu faço tudo na minha casa. Eu faço tudo, lavo roupa. Não passá, eu não passo, não. Só compro tecido que não dá de passar roupa [Risos]. Aí lavo"(Apuana).

Assim como Apuana, Anahi também cuida da casa, com a diferença de citar que, para esses trabalhos, usufrui da tecnologia, em especial para a lavagem de roupas. Anahi teve uma vida difícil. Casou com 16 anos, teve 13 filhos e ficou viúva, trabalhou como empregada doméstica e na empresa da mesma família para sustentar os filhos. Atualmente, aos 82, afirma que gosta de realizar os labores domésticos.

Faço sim [Trabalhos domésticos]. Porque hoje em dia até facilitou mais a gente tendo máquina, né? Não. Eu faço. Eu gosto mermo de fazer (Anahi).

Em outros casos, os filhos, em atitude de cuidados com a genitora, já não permitem que esses afazeres sejam realizados por ela.

Não, não. De fazer alguma coisa de serviço de casa [Não conclui]. A única coisa ás vezes, lavá um pratinho, que fica lá em cima. Ela fica brigando comigo [A filha]. Mas eu disse: não. E eu quando eu me deitava eu disse assim: não posso mais levantar, pode logo lá buscar o caixãozinho e deixa ali. [Risos] Porque enquanto puder me mexer [Não conclui] (Aracy).

Taynara, que foi criada com os mimos de filha caçula e trabalhou junto com o marido para ajudar nas despesas da casa, hoje, aos 82 anos, conta com graciosidade e orgulho que os filhos agora cuidam dela.

Tồ na casa dos filhos. Agora eles estão me governando, tão tomando conta de mim ainda bem, né? [Risos] (Taynara).

A participação da maioria das idosas no grupo de convivência do SESC ocorreu logo após a aposentadoria. A que entrou mais recente no grupo foi Anahi, há 8 anos. As demais já têm mais de duas décadas de convivência com a instituição. 
Já. já tá com uns 25 ano [Que participa das atividades no SESC]. Mana, faço só lazer. Pra mim é tudo (Taynara).

Já tá com 25 anos esse ano, em julho faz 26 anos (Apuana).

Desde 91 é 1991 [Período que iniciou a frequentar o SESC] (Tainá).

14 anos no SESC (Janaina).

[Tempo de participação nas atividades do SESC]. Está com 22 ano ou 23. Não lembro mais (Aracy).

Olha já com tô com oito anos [De participação nas atividades do SESC]. (Anabi).

Então, eu tô com, o tempo que tem o SESC. Só que eu fui cadastrada depois, né? Que eu frequentava esse lazer particular. Depois que eu me cadastrei que entrou a (Cita o nome da coordenadora), né? Eu fazia hidroginástica (Taynara).

$\mathrm{O}$ atendimento particular citado por Taynara refere-se a sua inserção como membro da comunidade em geral e não como participante do Trabalho Social com Idosos (TSI). Em nível nacional, este último serviço iniciou no ano de 1963, na cidade de São Paulo. De lá para cá, o programa foi se instalando em diversas regiões, Estados e cidades brasileiras. Atende anualmente em todo o Brasil em torno de 60 mil pessoas (SESC, 2017).

O TSI tem como objetivo principal oferecer uma melhor qualidade de vida a pessoas na terceira idade. As ações buscam estimular o desenvolvimento individual e coletivo do idoso na sociedade; promover a autoestima e a integração em diferentes ambientes; e reconstruir a autonomia por meio de cursos, práticas esportivas e outras atividades. A instituição tem como proposta, além de resgatar o valor social dos idosos, privilegiar a cidadania e a educação, por meio de projetos adaptados às diferentes culturas das regiões do Brasil (SESC, 2017).

As atividades consistem em ações voltadas para a valorização e a inclusão do cidadão idoso, através de reuniões, palestras, debates, atividades culturais, dinâmicas de grupo, entre outras atividades. A equipe técnica de cada localidade viabiliza ainda oficinas, cursos, atividades esportivas, seminários, eventos, passeios, atendendo às necessidades da clientela (SESC, 2017). 
Para participar do grupo de convivência de idosos do SESC, as pessoas precisam ter 60 anos ou mais, estar devidamente inscritas (não precisa pagar nada) e participar das reuniões semanais organizadas pela instituição. As reuniões têm como objetivo discutir e/ou informar as atividades que serão oferecidas pela instituição.

Para participar das distintas atividades de cultura, esporte e lazer oferecidas pelo SESC, as idosas, como qualquer usuário, necessitam pagar uma taxa. Entretanto, aquelas integrantes do grupo de convivência da instituição pagam um valor abaixo do que é cobrado para a comunidade em geral. $\mathrm{O}$ Programa de Assistência do Serviço Social do Comércio/SESC/Regional Rondônia, de Porto Velho, atua com TSI há 26 anos e reúne atualmente em torno de 400 idosos.

As inúmeras atividades oferecidas às idosas pela instituição convidam-nas para que estejam presentes vários dias da semana, conforme descrevem algumas depoentes.

Participo. As que eu pertence, participo. Olha, a minha turma é de quinta [Pensando] terça feira. Ma, eu frequento terça e quinta. Duas vezes, se tiver três eu vou três (Taynara).

Eu venho [Nas atividades do SESC] terça, quinta e sábado e com a professora [Cita o nome da professora] a gente tem o movimento segunda à tarde e quarta à tarde. É quatro dia, né? (Anahi).

$E$ as reuniões. Eu não falto. Agora nós estamos de férias, mas só não da bidroginástica (Aracy).

É duas vezes por semana e também faço [...] (Apuana).

Três. Não. É. É segunda, quarta e sexta (Aracy).

A convivência em grupos de idosos, a exemplo do programa do SESC, faz que os indivíduos assumam diversos "compromissos" e, assim, percebam que pertencem ao mundo, resultando em um envelhecimento com mais disposição e mais saúde.

As depoentes mencionam as atividades de que participam na instituição. 
Há, no grupo do SESC eu faço artesanato. Olha, ali uma cadeirinha que é pintada [Sinaliza com a mão]. Ela é forradinha. Tudo que tem lá eu participo. Trabalhos manuais. Trabalho manuais [Taynara].

A oficina da memória. É pra recordar o passado, né? Ai tem que recordar. Eu perdi o meu, meu cartão do banco e tô sem cartão. Só daqui a 15 dias vai chegar o próximo E ai, pra acertar a senha já pensou? Quantos anos heim? [...]. Não sei o quê [Não conclui]. Ai eu digo: dá esses número aqui aí eu dei. Aí até que enfim. Ainda bem que a sua memória lhe ajudou [Risos]. Só a nossa lá do movimento, lá. E a outra é a bidroginástica. [...]. Não. Dança não. Só assim, quando tem algum desfile alguma coisa, né? Às vezes eu entro. [...]. Eu faço movimento, faço aula da memória, a hidro da piscina. Só (Janaina). Faço dança de salão. É.. (Tainá).

[...] só do Carimbó que a gente brincava. E da dança cigana. É, dança cigana. Só, só disso. Fazia hidroginástica, fazia [Pensando]. Só o que eu fazia mais lá era, era hidro mermo. E ia, ia a reunião e pras festas com a [Nome da coordenadora] [Risos]. Isso ai ninguém perdia [Risos]. Isso aí ninguém perdia, né? Ai, eu aprendi crochê. Aprendi fazê crochê. Aprendi a pintá, fazê caixa de papelão. Essas besteira, aprendi por lá. Foi pos, pos banhos do [Interrompe]. Quando tinha banho do Souza [Nome de um balneário], a gente ia, ali do 21 [Quilômetro em que fica o balneário]. Também cansei de [Não conclui]. Fomos umas duas vezes com a dona [Nome da coordenadora] aquele banho lá do 21 (Jurema).

De lazer? Eu vou pra hidro, né? E ano passado comecei a fazê que eu gosto de fazê. Tomara que consiga eu me matricular é o com a [Cita o nome da professora], né? professora [Cita o nome da professora]. É. Eu faço bidro,e faço, comé? Esse da professora [Cita o nome da professora]. É, tem a dança que com uma professora, né? Como é nome dela já [Tentando lembrar]? Eu não sei a [Cita o nome da professora] deve saber (Anahi).

[Referindo-se ao SESC] Lá eu participo de dança, dança, dança, dança, vários tipos de dança, dança. Carimbó. Já dancei a cigana. Cada coisa que aparece eu, eu... [Pensando] frequento. Que eu posso eu participo. Faço [Tentando lembrar-se] bidroginástica (Yara).

[...] e faço também, até o ano passado eu tava fazendo aula de movimento com a professora [Cita o nome da professora] lá. [...]. Essa aula de movimento é um exercício que ela ensinava que eu falo pro meu médico que é melhor que a fisioterapia que ele manda eu fazer. [...] faço aula de teatro uma vez na semana. Lá quando tinha coral, a gente também fazia o coral (Apuana). 
Esses resultados não acompanham o que foi publicado por Dumazedier (apud Mori; Silva, 2010) sobre as atividades que predominam no tempo livre da maioria dos idosos. Para o autor, as práticas de lazer são quase sempre as mesmas que foram praticadas no tempo livre durante a vida ativa, sofrendo adaptações e manifestando apenas um ligeiro aumento na sua duração e frequência. As práticas de lazer dessas mulheres, tanto na maturidade como na infância, meninice e adolescência, são caracterizadas pela precariedade tanto quantitativa como qualitativa. O uso do tempo na ocupação com os compromissos de trabalho e do lar, atrelado à inexistência de espaços públicos de lazer são os principais fatores de restrição dessa prática.

Como práticas atuais de lazer, as idosas citam, predominantemente, as atividades físicas (a exemplo da hidroginástica) exercitadas no SESC. Ainda que as atividades citadas tenham um viés fortemente ancorado no enfoque da saúde, através da manutenção funcional do organismo, é certo que tais atividades também podem ser interpretadas como lazer, conforme mencionam Bruhns (1997) e Marcellino (2002). Para os autores, as diversas formas de usufruto do lazer dependem da essência que cada vivência pode ter para cada individuo; é caracterizada pelo modelo de relação que se estabelece entre o sujeito e a experiência vivida. Depende basicamente da satisfação provocada pela atividade. Reforçam Mori e Silva (2010) que as práticas de lazer têm um papel importante, na vida dos idosos, pois proporcionam a esse coletivo uma vida mais descontraída, com mais socialização, interação com outras pessoas e culturas. Além de participação na vida social, favorece que assumam compromissos de modo enriquecedor e criativo, com consequente inserção no meio sociocultural.

Entretanto, apesar de desfrutarem das atividades, a condição física de algumas depoentes já não responde mais ao desejo de se movimentarem conforme exigência das práticas de lazer ofertadas.

[...] e até hoje aqui e ali eu ainda entro num grupo de dança, mas sendo uma dança mais calma, não muito agitada mais. Porque eu não aguento (Apuana). 
Olha eu participei de vários, né? [Referindo-se às atividades do SESC]. Porque na época que ainda tava bem das minhas pernas. Ai, a gente jogava, fazia monte de coisa. Caminhada, fazia [Não conclui]. Ai, comecei a ir para hidroginástica, né? Ai, eu sai do negócio de jogar, né? Ia pra bidroginástica. Ai, depois, eu deixei [Tentando lembrar]. Esqueço até hoje da bidroginástica. Banhos, passeio. Fui em vários, vários mesmo. Eu fazia assim até o ano passado. Ainda foi mais perto, né? Que o ônibus vai de manhã e volta à tarde, né? Mais assim. É, nunca mais fui não, mas agora eu já disse com a perna boa ou ruim eu vou participar (Aracy).

Já fiz várias [Referindo-se a viagens]. Mais eu parei depois que adoeci das pernas. Chegava lá que era o ônibus deixava a gente no canto, né? Ai tinha aquelas descida. Andava bastante. Ia para festa de noite e tudo. E eu ficava lá parada. Sem poder [Não conclui]. Eu digo: não adianta, né? (Aracy). Agora não tô indo nenbuma vez. [Risos]. Quando eu tava boa eu ia. Agora que abaixou. Lá, eu e eu e o dia que era marcado mesmo porque tinha por, tinha vez, né? Tinha de terça-feira e de quinta, né? Ai a gente tava na de quinta. É, só na de quinta. É, acho que é. Tenho vontade de ir [Para o $\mathrm{SESC}]$, mas não posso. As minhas pernas, né? Eu não posso caminhar, né? O principal a gente poder caminhar, né? A gente poder caminhar, a gente pode fazer alguma coisa, né? Sem caminhar, né? (Jurema).

Olha eu já frequentei todas as atividades que tinham no SESC, [Risos]. Mas depois que eu adoeci da perna eu parei um pouco, né? Das atividades. $E$ até o seu tempo nós fazíamos a... [Tentando lembrar) qual era o nome? [Tentando se lembrar]. O mo, movimento [Risos]. E eu fazia (Tainá).

Com Apuana, Aracy, Jurema e Tainá, percebe-se a necessidade da ampliação de oferta de outras práticas, mais adequadas às suas condições físicas, a exemplo daquelas de caráter social, cultural e artístico, com características intelectuais e manuais. As reuniões e encontros para chás, já oferecidos pelo grupo Pioneiras de Rondônia, parecem ser boas opções para aquelas que se encontram com a mobilidade reduzida.

Justifica-se a alusão anterior quando se identifica que as atividades de maior preferência das idosas são aquelas que implicam em movimento corporal. A ampliação de oferta de práticas sociais, culturais, manuais e intelectuais pode contribuir de forma decisiva para que continuem frequentando 
a instituição, mesmo quando estiverem sem mobilidade suficiente para as práticas corporais. A seguir, relatam as práticas de lazer de suas preferências.

O movimento [Nome de uma prática de exercício físico oferecida no SESC]. Eu gosto do movimento. Eu me sinto bem. É. Depois do movimento é dança (Anahi).

A dança (Yara).

Eu gostava da bidroginástica. Gostava muito da bidroginástica. E os passeios. Os passeios eu gostava de ir para banho. Ah! não perdia um banho quando tinha (Jurema).

Olha até hoje, é só mesmo a hidroginástica. Porque quando eu entro lá na água parece assim que eu não tenho nada nas pernas. Eu faço. Tem gente que se admira, mais outro não. Eu tinha vontade de aprender nadar. Também nunca [Não conclui] (Aracy).

É a recreação do movimento. Gosto mesmo. Não perco nenhuma. Só se eu tiver viajando ou doente. [...]. Dançar, dançar [Indicando que também gosta de dançar] (Taynara).

Chama a atenção as atividades físicas (hidroginástica, por exemplo), praticadas pelas idosas nomeadas como lazer. A essas vivências, atualmente, são atribuídas funções fisiológicas para melhoria da saúde, entretanto, para as idosas, são práticas lúdicas. Essa variedade na atribuição de sentidos de uma mesma prática nos faz recordar que o significado conferido a uma atividade não tem origem na atividade em si, mas no sistema de valores e aspirações pessoais, conforme destacaram Witt e Bishop (apud Nunes; Hutz, 2014).

Observaram-se casos que contradizem o que afirma a publicação de Simões (apud Mori; Silva, 2010). Segundo o autor, os idosos "rejeitam o próprio corpo, julgando-se feios e incapazes, mascarando o aspecto mais positivo que é o viver ou o estar corporalmente vivo". Com Taynara, 82 anos, constata-se que o processo natural de declínio biológico não é motivo para não desfrutar dos prazeres da vida como dançar. Evidentemente que precisa de pessoas ao seu redor que a ajudem na superação 
de algumas limitações físicas naturais, para que possa praticar uma das atividades que mais gosta que é a pescaria.

Ab! É de pescar. Menina, eu gosto muito de pescar. Pego até Pirarucu [Espécie da região Amazônica que quando adulto costuma variar de dois a três metros, e o peso, de 100 a $200 \mathrm{~kg}$ ]. Ai, eu gosto demais. Tu sabe que eu pego Pirarucu? Onde tiver botando peixe [Explicando os locais que costu$\mathrm{ma}$ ir pescar]. Pesca no pesque e paga [Pesque-Pague]. Pesco no Candeias [Nome de um rio que passa em um município vizinho a Porto Velho]. Pesco no Jamari [Nome de um rio que passa em Porto Velho]. Pesco no Salsalita [Nome de um balneário privado, localizado em Porto Velho]. $E$ donde tiver dando peixe, eu vou lá. E pego mermo. Menino [Dando ênfase], um tempo desses eu peguei um saco assim de sardinha Demonstrou com as mãos]. Pescaria é lazer. Eu penso. Sim. Uma coisa, olha aí. O pessoal da igreja, né? Gosta muito de fazer [Não conclui]. No dia de quinta feira. Já veio até as meninas lá do SESC aqui fazer reunião, aqui em casa. Ai, né? Quando eu saía, via, sozinha, ficava com dó que eu ficasse só e me chamam pra ir pescar. Eu vou pescar. Desço ladeira no Candeias (Município de Rondônia). Alta, até lá dá. Meu Deus do Céu. Eu piso no ombro deles; outro fica um em baixo, outro em cima. Eu piso pra descer porque ás vezes não tem escada. Mas olha, e é lá da Assembleia [Igreja Assembleia de Deus], heim? Irmão Carlos era um bichão lá da Assembleia. Lá ele e o irmão dele. Vamo irmã Raimunda Pescar [...]. Eles querem pegar só peixe grande e eu pego de todo tamanho. Peixinho pra gente comer frito, né? (Taynara).

Janaina admite que o SESC é o seu único espaço de lazer e afirma: Lazer "Só o do SESC". A instituição tem sido para as idosas um local que oferece atividades para ocuparem o tempo livre, local para a prática de exercícios físicos; tem sido para algumas a única oportunidade para desfrutar de momentos de lazer.

Melhor época da minha vida que eu já peguei foi esse lazer de Rondônia, do SESC (Taynara).

[...] e depois foi que a Dona [Cita o nome da coordenadora do SESC] a passeá, passeá. Eu passiei muito depois de velha. Nunca pensei na minha 
vida em andar tanto como eu andei. Depois que ele morreu [O marido], nós fumo para Caldas Novas, fumo Bertioga, fumo pra Belo Horizonte, fumo pra Grussai. Fumo [Não conclui]. Ichi, tem tanto lugar que eu foi, que eu nem conto" (Jurema).

[...] agora tem muitas pessoas que eu não sei [Não conclui]. Que eu já falei assim: eu sou muito calada. Tem gente que diz que eu sou, mas não é não. É porque eu não gosto tá me servindo de uma coisa e tá falando mal. Eu não gosto disso. Eu a Dona [Nome da antiga coordenadora do TSI] [Não conclui]. Eu ficava chateado quando viu a pessoa falando da [Nome da antiga coordenadora do TSI], sabe? Tem que talvez [Não conclui]. Que eu não aguentei disse: olba o dia que eu não gosto mais do SESC eu saio. Mais eu aqui não ponbo [Não conclui]. Como se diz, defeito em ninguém. Aqui todo mundo para mim é bem. Todo mundo para mim ébom (Aracy).

O SESC tem sido um ambiente favorável para encontro entre as idosas, ainda que as atividades da instituição não se identifiquem com características inovadoras. Ao contrário, apresentam fortes rasgos paternalistas e assistencialistas nas ofertas. Entretanto, diante da trajetória de precariedade de lazer das idosas, de total desassistência, há que destacar os pequenos avanços nas vivências lúdicas na vida dessas mulheres no SESC.

Jurema diz que nunca imaginou que pudesse agora, nessa fase da vida, aproveitar tão intensamente. A trajetória de vida dessa mulher é marcante. Não conheceu os pais, nunca frequentou a escola e ainda criança era responsável pelos trabalhos domésticos em troca de casa, comida e roupa, junto à família que a abrigou. Outras idosas desse estudo tiveram trajetória de vida semelhante. Não é de se estranhar que, para algumas delas, a exemplo de Janaina, Taynara e Tainá, o SESC tenha se tornado a única referência de lazer.

Essa supervalorização da instituição decorre principalmente da falta de opção dos idosos com outras organizações e espaços de lazer e convivência. A cidade de Porto Velho apresenta precariedade de infraestrutura como praças, áreas de lazer com equipamentos específicos, centros comunitários, casas de cultura, entre outros espaços. A precariedade aumenta quando se pensa em espaços devidamente adaptados para os idosos, apon- 
tando para a inexistência ou insuficiência de políticas públicas de lazer voltadas a essa população.

Motivação para as atividades que pratica no SESC:

[Dizendo quem recomendou o SESC] Foi o doutô Valter, o médico. Problema de saúde. Minha barriga tava muito grande, tava dando defeito na minha coluna. Ai, eu fui no, nele, né? [No médico]. Me consultar. Ai, ele falou que a mãe dele tinha o mesmo problema e ficou boa com hidroginástica. E o movimento que tivesse que pudesse fazer eu podia fazer e até hoje eu faço (Taynara).

Não. É que quando eu me aposentei eu tive problema de depressão, né? Ai eu comę̧ava a tomar remédio, remédio. Eu falei: quer saber duma coisa, eu vou já lá no SESC (Janaina).

Essa história. Depois que, depois que ele morreu [Referindo-se ao marido], é que eu vim. Eu passei [Não conclui]. Até não queria entrar no SESC, né? Porque eu trabalhava aqui negócio de salgado fazer salgadinho. História de vendê e coisa. E eu digo: se eu for pro SESC eu vou deixar de fazer, [Referindo-se a fazer salgadinho para vender]. Ai, eu digo: vambora, né? Ai nós fomos. Foi que eu me escrevi lá. Acabou que eu deixei de fazer os trabalhos aqui de casa. Sempre fazendo para lá. E começaram a me encher lá, que eles começaram a me chamar até de salgadinha. E eu fazer as coisas e levar para vender lá mesmo e assim foi a vida (Jurema).

Constata-se, com Taynara e Janaina, que a principal motivação para ingresso no grupo de convivência do SESC foi o benefício para a saúde e o bem-estar. Apesar de as depoentes manifestarem sentir prazer nas atividades de que participam, constata-se que a busca pela instituição se deu mais para e pela conquista da Saúde do que por uma motivação de participação social. Já Jurema, que conhecia a instituição e o programa dos idosos, por ser um espaço onde comercializava seus produtos alimentícios, aproveitou também para desfrutar das atividades.

Mas, nessa instituição, a procura de atividades pelos idosos é maior do que a demanda. $\mathrm{Na}$ fala das depoentes, denota-se que dependem da existência de vagas para participarem de determinadas atividades do SESC. 
Ai, fui lá. Tive uma sorte com a [Cita o nome da coordenadora]. Lá tinha uma vaga. Já peguei logo (Janaina).

Não é. Não é porque tem atividade lá e a gente escolhe o que a gente quer fazer. Ai, se a gente pegar uma vaga, a gente vai (Apuana).

$E u$, tomara que pegue essa vaga esse ano porque tem muita gente e eu já tô muito antiga lá (Taynara).

É muita gente. Porque agora, eu queria trocar o meu, o meu horário, né? Que tá, eu tô achando ruim, de pegar sete horas. Eu num tô em casa sete horas (Taynara).

Referente ao lazer das idosas com suas famílias, observa-se a presença dos filhos em algumas atividades.

Só com os filhos. Quando eu saio com eles, né? Que eu vou para o lazer, assim no Cacoal, Candeias [Balneário privado localizado em Porto Velho]. [...]. Sim. Menina, ai, olba como eles querem que eu vá fazer o lazer com eles, né? Num tem escada nem nada. Ai, desce um, pega um cipó lá que tem na beira do rio, né? Ai eu piso no ombro deles e o outro me segurando lá em cima. E assim nóis sai pra nosso lazer, pra mim pescar pra eles. Olha se eles vão pra Cacoal eles me levam. Se [Não conclui]. Pra todo canto que vão, eles me levam. Ai, se não me levam, eu fico reclamando. É. Se num ligarem pra mim eu ligo [...] (Taynara).

Com Taynara, observa-se o lazer em família e o interesse dos filhos em ter a companhia da mãe. Com essa depoente, observa-se também a presença de vitalidade e ausência da fragilidade.

Já para Yara, a participação da família nas práticas de lazer está condicionada ao tempo que os filhos podem dispor para acompanhá-la.

A minhas filhas participam, quando elas têm tempo ela vai. Eu tenho uma chama-se [Fala o nome de uma filha] que está fazendo, que é a doutora [Menciona o nome da filha novamente], que ela está fazendo bidroginástica comigo lá no SESC (Yara). 
Mas o mesmo não ocorre com as demais depoentes. Observaram-se casos em que elas não desfrutam de lazer em família.

Com minha familia não [Não tem atividade de lazer com a família]. Final de semana é difícil eu sair porque eu venho pra cá [Casa do filho]. Ainda mais agora com meu filho doente (Anahi).

É muito difícil porque eles só querem andar onde eu não gosto. Gosta de mato, gosta de Forró, gosta de beber. Muito difícil eu ir. Agora, agora já vem o réveillon, né? Vai ser lá, diz que no bairro Novo [Nome de um bairro da cidade de Porto Velho]. Porque eu tenho uma neta que mora lá naqueles apartamento e vai ser lá o a festa lá. Já tô pensando que tenho que ir (Janaina).

Não. [Não desfruta de lazer com a família]. Muito difícil. Mas porque eu não quero. Nem ele também. Ele gosta mais é de acampar, de ir pra lago essas coisas. Pra mim já não dá pra tá levantando barraca, nem armar barraca. Pra deitar, levantar é ruim (Apuana).

Muito difícil, né? [Referindo-se a momentos de lazer em família]. A não ser assim às vezes no sitio um dia de domingo. Até hoje ainda tem a merma agonia vai tudo pro sítio eu que não gosto muito. É. Quando é fim de semana vão embora pro sítio. Eu vô nada, não quero saber de mato (Janaina).

Os diferentes interesses dos filhos com relação aos interesses das mães têm sido, para algumas depoentes, empecilho para práticas de lazer em família. Os depoimentos citados indicam que os filhos esperam que as idosas se adaptem às preferências de lazer deles e não reservam um momento para atenderem às demandas das mães.

Além das participações nos grupos de convivência, algumas delas buscam individualmente atividades que lhes dão prazer e ajudam a preencher o tempo, que parece ficar mais longo quando se chega na terceira idade.

Eu fazia, eu fazia, ponto cruz e ponto cruz. Mais agora deu pra [Não conlui]. Fico com isso doendo demais [Mostra os braços]. Eu fico, mais eu não deixo. Compro pano só para dar pra filha. Nunca vendi nada que eu faço, faço. Eu gosto jogar dominó, só que não tem com quem. Só com a tua mãe [Risos]. Tadinha, agora não pode mais (Aracy). 
Me perco mais é fazendo os meus crochês, meus tricô, bordando. Me perco mais no tempo assim (Apuana).

Para preencher o seu tempo, Jurema até hoje trabalha na preparação e venda de suco embalado em saquinhos.

Em casa eu faço bem, só mermo meu dim dim [Suco congelado em um saquinho de plástico] que eu tô fazendo agora para não ficar parada. Que eu não gosto de ficar parada sem fazer nadinha (Jurema).

Apuana, que trabalhou intensamente na infância, meninice e maturidade, hoje com 80 anos, trabalha na loja do filho, justificando que, por um lado, ele não pode pagar uma funcionária; e, por outro lado, porque não quer ficar sozinha em casa.

E vivo aqui na loja ajudando ele [O filho, empresário]. Porque não tem condição de pagar funcionário e pra mim não tá só em casa [Não conclui]. Que eu vivia só no hospital. Ai eu pedi pra ele, pra mim vim pra cá. Ai, por isso que eu tô aqui [Apuana recebeu a equipe de pesquisadores para a entrevista na loja do filho em que trabalha] (Apuana).

A realidade vivida por Apuana acompanha o que dizem Mori e Silva (2010) sobre as dificuldades dessa população de ampliar suas práticas de lazer. De acordo com os autores, o fato de não terem tido acesso a conhecimentos sobre lazer e nem vivenciado essa prática na escola ou fora dela, interfere negativamente na aquisição de novos hábitos. Os resultados aqui também se assemelham aos achados de Mori e Silva (2010), desenvolvidos no bairro Ferradura Mirim de Bauru, no Estado de São Paulo. Nas duas realidades, as idosas tiveram poucas oportunidades de adquirir conhecimentos que lhes conferissem uma compreensão mais aprofundada sobre o lazer. Esse fato ocorreu porque elas faziam parte da classe trabalhadora, que foi excluída de uma Educação Sistematizada para esse fim. Por outro lado, na velhice, ocupar o tempo é uma preocupação, pois ficar sem fazer nada é relacionado à solidão, à tristeza, a sentimentos negativos (Ploner; Michels; 
Oliveira; Strey, 2017), daí Apuana preferir trabalhar no comércio do filho a ficar ociosa e solitária em casa.

Segundo Pont Geis (2003), com o passar dos anos, a tendência é que os idosos se afastem de seus familiares, fiquem longe de seus entes queridos. No caso das depoentes deste estudo, parece ser que esse afastamento da família, em especial dos filhos, pode decorrer, entre outros aspectos, da diferença de interesses e bem como das limitações físicas das idosas.

Entretanto, a família tem um papel fundamental de apoio no envelhecimento. Conforme estudos de Ploner, Michels, Oliveira e Strey (2017), a família aparece como um lugar propício para as relações de afetividade. $\mathrm{O}$ lazer favorece a interação, a troca de carinho e cumplicidade, fortalecendo os laços familiares e contribuindo para a pessoa idosa ter maior sensação de conforto e segurança.

Provavelmente em busca de conforto e afeto junto a seus pares, as idosas integrantes deste estudo criaram, em 2010, o grupo de convivência Pioneiras de Rondônia. Todas elas são participantes do TSI do SESC.

O grupo "Pioneiras de Rondônia" se dedica à organização de viagens e apresentações de danças, fora e dentro do Estado de Rondônia.

No momento ele [O grupo Pioneiras de Rondônia] ainda está em começo. Nós temos viagens e danças fora daqui. E aqui mesmo. Quando é preciso nós apresentamos as danças (Yara).

Como foi dito, a criação do grupo é recente. Entretanto, já desfruta de uma programação criada pelas líderes da Associação que envolve apresentações de danças, desfiles, chás e, principalmente, viagens dentro e fora do Estado de Rondônia. As falas de Apuana e Yara deixam algumas pistas sobre as motivações para a criação do grupo Pioneiras de Rondônia. Uma possibilidade é que o SESC já não estava atendendo as expectativas das idosas na sua totalidade, principalmente no que se refere a viagens.

Eu entrei no SESC eu trabalhava lá, fazia enfeite. Todo quanto era curso eu participava de lá. Nóis viajava muito. Nóis brincava muito. Ensinei o carimbó lá e a gente dava aulas pras pessoas lá de carimbó. Nóis formamos 
nosso grupo. [...]. Já pelo SESC mesmo eu já fiz muita viagem quando era a outra coordenadora. Depois que ela saiu, já ela não pode mais fazer viagem com nóis. O chefe dela tirou, ai nós arrumamos um outro grupo [Referindo-se ao grupo Pioneiras de Rondônia]. Nóis tamo formando e a gente viaja muito (Apuana).

Olha, da viagem do SESC, que não tenho frequentado nada pelas viagens do SESC. Mas eu tenho amiga que ela tem um grupo e eu frequento este grupo, [...] [Referindo-se ao grupo Pioneiras de Rondônia] (Yara).

De modo informal, algumas depoentes disseram que, com a troca de coordenadora do SESC, o TSI já não organiza mais viagens específicas com os idosos; e que esse tipo de atividade foi destinada ao setor de turismo da instituição. Desse modo, as programações e roteiros de viagens bem como as condições de pagamentos, entre outros aspectos, não são planejados especificamente para os idosos integrantes da instituição; e sim destinados para a comunidade em geral. Anteriormente, havia uma atenção diferenciada para essa população, que viajava para encontros nacionais destinados a pessoas da terceira idade, além de outros eventos.

Com a formação do grupo "Pioneiras de Rondônia", algumas idosas mantêm a programação de viagens aos eventos nacionais destinados a elas, especificamente.

[...] e fora do Estado, nós vamos aos encontros da melhor idade. Ai, no Brasil pelos estados do Brasil. O ano passado, este ano. O ano foi em [Pensando] foi na Bahia. Este ano foi em [Pensando] ai Recife. Olha, nós fazemos um cronograma anual e já fica tudo marcado. Porque nós temos esses encontros fora do Brasil que, que é muitas vezes, tem 1.200 pessoas ou mais. Nós já fazemos o nosso cronograma desde do início. É são muito bons. Vocês poderiam ir também nesses encontros fora de Porto Velho. É. São muito bons e vocês que trabalham com idosos, né? Deviam ir. Tem, tem do Juarez [Nome de um coordenador de evento nacional] que é em maio. Tem um outro da melhor idade também em maio, em São Paulo, este ano. E tem o do Carlinhos [Nome de uma coordenador de evento nacional], que é o Inarai, que tem em março, que vai ser aqui no [Não conclui]. Ai meu Deus, aí perto do Paraguai, em Foz do Iguaçu. E o outro de outubro que será no Rio de Janeiro (Tainá). 
Tainá praticamente já não participa mais da programação das atividades do SESC.

Olha, Pioneiros. Eu participo de todas as atividades, né? tem passeios, passeios aqui na cidade, viagens a aqui a sede do Pioneiras de Rondônia. Nós ensaiamos. [...]. Não. [Não tem participado das atividades do SESC]. Eu tenho participado só com o nosso grupo. É umas quatro, quatro, cinco viagens por ano, de avião e de ônibus [Risos] (Tainá).

Igualmente, nas viagens organizadas pelo SESC, também no grupo Pioneiras de Rondônia, cada interessada é responsável pelo pagamento de suas despesas.

Por mim mesmo com meu dinheiro [Risos]. É, mais eles [Fazendo referência aos filhos] dão também. Ajudam, dão passagem (Janaina).

Eu [Responsável pelo pagamento das viagens]. É com a minha aposentadoria (Apuana).

É. Quem custeia a minha sou eu mesma. É. [Risos] (Tainá).

Quando era de avião, a gente pagava a prestação, né? Sempre fui eu, ninguém nunca... [Não conclui] [Risos]. Que às vezes, por exemplo, vai, vai daqui 4 meses vai fazer uma viagem, ai a pessoa já comprou a passagem ejá fica descontando, né? É assim (Aracy).

A financia é, é financiada por nós mesmos. Cada um financia a sua. É cada um paga o nosso. Só que ela faz o pacote né? Já incluindo tudo, e [Não conclui]. Ai, a gente paga no, no [Incompreensível] na agência de viagem, parcelado (Yara).

Ainda sobre as viagens para os idosos em geral, e considerando o valor das despesas, as depoentes dão a entender que a avaliação sobre a acessibilidade vai depender das condições financeiras de cada um. Tainá não julga as viagens caras, mas reconhece que, por questões financeiras, nem sempre consegue viajar. Yara e Jurema consideram os preços excessivos. A primeira justifica que se trata de viagem de avião e que os preços são fixados pela agência; já Jurema afirma que, mesmo caro, sempre dá um jeito para participar dos passeios. 
Pra mim, eu num acho. Eu acho [Não conclui]. Tá dentro do meu orçamento [...]. Dá pra eu pagar. Quando eu vejo que não dá, não vou, né? Não vamo, num sei o quê. Mas se não der eu num vou. Não. Num vou pertubá meus meninos [Referindo-se aos filhos] (Taynara).

Olha, não é de dizer que é caro. É caro pra quem tem. Mas pra quem não tem é caro. Por exemplo, uma pessoa que ganha um salário minimo, não tem condições. Mas não é porque [Tosse] a nossa, a nossa coordenadora queira, é de lá da agência mesmo que já vem a carestia. O avião é caro [Incompreensível]. É então já vem o preço certo. Então é isso aí. Não é que [Não conclui]. Ab! porque fica, fica, [Não conclui]. Porque antigamente diziam que ficava (Yara).

Era caro mais a gente dava um jeito e ia mermo [Risos] (Jurema).

Uns dizem que é caro, mas eu acho que não porque se a gente paga. Essa última que nóis fomo agora, eu paguei três mil [Reais] e um pouco. Mas a gente já vai com tudo pago. Nóis não abre a bolsa pra nada. Só quando a gente que passeá em outros cantos que a gente tira. Mas sendo isso já vai com hotel com tudo pago alimentação. E você come do bom e do melhor. Nóis mesmo paga. Cada uma paga a sua (Apuana).

Quase todas as idosas são de origem pobre e, com a chegada da terceira idade, algumas delas passaram a ocupar outro lugar no espaço social, conquistado na maior parte dos casos através do trabalho. Com a chegada da aposentadoria e/ou recebimento de pensão o espaço social se amplia para essas mulheres. Ainda que compartilhando alguns espaços de lazer e ainda que as condições sociais não sejam demarcadas com clareza, as diferenças econômicas permanecem iguais que na adolescência e na maturidade de algumas idosas. Essas diferenças definem algumas restrições às práticas de lazer. Segundo Ploner, Michels, Oliveira e Strey (2017), apesar de ricos e pobres se aposentarem, se aposentam em condições sociais desiguais. De acordo com os autores, a renda das camadas populares não favorece as inserções no lazer; já as camadas superiores conseguem suprir suas inserções no lazer de modo mais abrangente. Essas diferenças podem ser observadas no discurso das depoentes quando fazem menção às suas participações nas viagens. Citam os autores: existe "uma velhice masculina 
e outra feminina; uma dos ricos e outra dos pobres; uma do intelectual, outra do funcionário burocrático, ou do trabalhador braçal” (p.125).

Hoje que eu viajo pouco, né? Só umas quatro vezes por ano [Risos] (Tainá). Pelo SESC não. Mas eu viajo todo ano mais por conta própria. Sempre vai alguma pessoa comigo. Às vezes vai da família, às vezes alguma moça, alguma colega que quer conhecer, né? Ai eu levo, né? (Janaina).

Não [Nunca viajou com o grupo]. Não porque eu acho assim, eu ganho pouco e pra mim ir eu pago. Não viajo, sempre eu que dizer da minha casa eu vou pro Humaitá [Município do Estado do Amazonas que fica próxima a Porto Velho] passear casa da minhas irmãs. [...] (Taynara).

[...] [Não viaja] porque tu sabe, a a gente só pode fazer uma coisa quando a gente pode. Eu já pago aqui, né? [Referindo-se à taxa que tem que pagar no SESC] (Anahi).

Vou. Assim que posso. Não vou agora em março porque eu tô devendo uma passagem do ano passado e quero fazer meus oitenta anos e eu tenho que fazer economia. Se eu não fizer eu, não vou fazer. [...]. Tem duas, três [Viagens por ano], mas eu só vou uma. [Risos]. É. O salário não dá não (Apuana). Ano passado, só foi [Não conclui]. Ano passado em nenhum [Nenhuma viagem]. Ano retrasado que eu ainda foi. Pra lá, pra, pra coisa... [Pensando] comê, pra ali, pro Pai Eterno. Foi. Que nós foi. Que eu foi. Depois e nunca mais viajei não (Jurema).

As depoentes anteriormente citadas são aposentadas, mas não dispõem igualmente das mesmas condições financeiras para desfrutar das viagens. Aqui se constatam claramente as diferenças de acessibilidade ao lazer turístico, fortemente condicionado pelo aspecto econômico. Enquanto Tainá, por exemplo, pode viajar quatro vezes por ano, Anahi e Taynara nunca viajaram com o grupo. A primeira não viaja e destaca que precisa pagar as taxas para participar das atividades no SESC. Para diminuir os custos das taxas, Taynara consta na instituição como dependente do filho, que é comerciário; e nessa condição os valores são bem mais acessíveis para ela. 
Pelo grupo do SESC, eu tô na a carteira do meu filho. Que professor de engenharia lá no na Faro [Nome de uma Faculdade de Porto Velho]. Ai, eu peguei a carteira dele, que sai mais barato para mim. Sou esperta, né? (Taynara).

Para os idosos, integrantes do TSI do SESC Porto Velho, as taxas são 50\% menores do que os valores cobrados para a comunidade em geral. Apuana fala claramente que o seu salário não é suficiente para custear todas as viagens que são programadas. Essa realidade de algumas idosas é retratada por Mori e Silva (2010). Citam os autores que os valores pagos para o aposentado, para a maior parte da população brasileira, tem se revelado insuficiente para prover necessidades básicas dos idosos, não lhes dando a segurança suficiente para viverem de forma mais estável. Desse modo, o investimento em práticas de lazer é relegado a planos inferiores.

Para Aracy, as limitações físicas da idade e problemas de saúde, que a deixam por vezes fragilizada, são impeditivos para o pleno usufruto das viagens de lazer de forma autônoma.

Só que agora se eu quiser viajar [Não conclui a frase]. Já até combinei de eu pagar passagem para [Cita o nome de uma moça, amiga da família] para cuidar de mim, né? Não vamos confiar em colega não. Porque para deixar a gente lá para trás e não olha. Tá bem. Pode fazer tudo, né? E eu ficava chateado com isso, né? (Aracy).

A companhia do marido nas viagens já foi considerada uma dificuldade para o maior usufruto dessas vivências.

Ah! De todas as viagens eu gosto. Depois que eu fiquei só, sem marido, de todas as viagens eu gosto. Porque quando eu vivia com o marido que a gente ia com a [Cita o nome da coordenadora] eu não apreciava nada quase. Ele tinha muito ciúmes. Brigava demais (Apuana).

Apuana, que começou a trabalhar no roçado e em casas de família na condição de empregada doméstica sem remuneração nenhuma desde os 7 anos de idade, sofreu na maturidade e na velhice com a violência de seus 
companheiros. O primeiro marido quis matá-la, precisou fugir para evitar uma tragédia; e o segundo tinha demonstrações frequentes e excessivas de ciúmes, que acarretavam discussões entre o casal. Uma investigação de Belo (2013) mostrou que as idosas que vivem (ou viveram) na zona rural do Estado Pernambucano eram tratadas pelos seus maridos, em geral, com brutalidade, como muitas de sua época e das regiões do interior. Complementa a autora que elas não avaliam a brutalidade de seus esposos como violência e, sim, como um comportamento ou "jeito de ser" comum no cotidiano de todas elas. Parece ser que Apuana se rebelou contra essa realidade relatada por Belo. Sua história de vida, pautada em carga excessiva de trabalho e privação de lazer na meninice e maturidade, juntamente com a vontade de viajar e conhecer novos lugares, parece ter exercido importante motivação.

[...]. Olha. Pra te falar a verdade, todos os lugares eu tinha vontade de ir. Que eu nunca sai de casa [Risos]. Então, quando aparecia a oportunidade eu adorava ir [Com intensidade]. Queria ir mesmo (Apuana).

Os depoimentos registram o prazer da viagem e o desejo de conhecer o mundo além da localidade amazônica, onde viveram toda uma vida. Entretanto, as viagens de lazer, na maioria das vezes, se limitam às programações dos eventos aos quais participam (a exemplo do "Dedo de prosa") e as compras. Não se observou concentração e/ou comprometimento com visitas a locais turísticos ou com conhecimentos sobre o modo de vida das populações visitadas. O tipo de lazer ofertado apresenta rasgos de um entretenimento ligado ao consumo alienado, que se distancia de vivências que remetem a valores educativos e suas possibilidades como instrumento de mobilização e participação cultural, conforme afirmou Marcellino (2007).

O desejo de Apuana de conhecer novos lugares e a disposição de Taynara para as atividades de pescaria negam a ideia das velhinhas incapazes e sem objetivos na vida, sem condições de fazerem escolhas e tomar decisões; de um perfil de idoso que resulta no esvaziamento do sentido de existência e que desencadeia processos depressivos no indivíduo. Apuana reforça: 
Eu sempre fui animada. Fui uma pessoa que eu não tinha lazer. Não tinha essas coisas. Mas eu sempre gostei, sempre foi animada. Sempre eu procuro cutucá nos outros que é pra puxar pra fazer. É, porque pra gente tá sozinha, num dá não. A gente não deve se entregar porque tá idosa. Ab! porque tô idosa não vou fazer isso, não vou fazer aquilo. Já tô velha. Não, a gente, tem que [Não conclui a ideia]. Enquanto Deus dá vida pra gente, a gente tem que ajudar ele também a procurar a se manter a se erguer. Não esperar só por remédio, nem pelos outros que vem não. Vamo ali, segura na mão dos outro, vai pra lá. Acostuma mal (Apuana).

Nessas mulheres, constata-se que não há uma negação da sua condição de velha. A relação entre a idade e a falta de vitalidade, ao cansaço, à doença, ao asilo, à incapacidade e muitos outros aspectos negativos mencionados por Ploner, Michels, Oliveira e Strey (2017) não se aplicam a elas. Apesar de terem perdido o viço da juventude, da presença de cabelos brancos e das rugas, das memórias não serem expressas com tanta fluidez, elas se sentem motivadas para desfrutar os prazeres do lazer e manifestam isso expressando seus gostos e preferências, seus desejos e vontades.

Repetiu-se, na fala da maioria das mulheres, a afirmativa de que somente nessa fase da vida é que se identificam tendo momentos de lazer. Os dados encontrados no estudo acompanham o que foi citado por Mori e Silva (2010), quando lembram que o lazer, como fenômeno social, na idade coincide em muitos casos com a aposentadoria. De fato, no caso das idosas da Amazônia investigadas, somente com a aposentadoria elas puderam usufruir intensamente o lazer. Para as depoentes, a velhice trouxe com elas a aposentadoria, que significou um momento único em suas vidas para se dedicarem a atividades atrativas e de caráter pessoal. A saída da rotina intensa de trabalho, dos cuidados com a casa e dos filhos e a oportunidade de desfrutar um pouco os prazeres da vida são motivos para celebrar a velhice.

Depois de velha foi que eu vim participar. E se divertir. Depois de idosa foi que eu fui [Não conclui]. Depois que ele morreu [Referindo-se ao marido], foi. Eu vim participar, né? (Jurema). 
Aproveitei! Pois é isso que eu digo, uma coisa que eu não esperava, né? Porque ainda quando eu era nova não teve essa oportunidade, né? Agora depois de velha foi que eu vim achar essa oportunidade, né? Pra mim foi um privilégio, né? De ter achado essa [Incompreensível] (Jurema).

[...] e sofri. Sofri mesmo por isso que é bom sofrer quando é nova pra depois de velha ter um lazer, né? (Taynara).

Essa alegria manifestada pelas depoentes não é compartilhada por homens e mulheres, conforme afirma Sant'Anna (apud Ploner; Michels; Oliveira; Strey, 2017). Segundo o autor, as mulheres, quando comparadas aos homens "[...] vivenciam mais intensamente a $3^{\text {a }}$ idade como uma nova etapa da vida [...]" (p.100).

Citam Mori e Silva (2010) que o lazer tem um papel significativo, pois pode proporcionar às pessoas oportunidade para se expressarem, sentirem prazer, criarem, se divertirem, descansarem e se desenvolverem. No que se refere à expressão e ao desenvolvimento, um aspecto importante a ser considerado é o grau de participação das idosas nas tomadas de decisões. As idosas foram questionadas sobre quem decide as atividades a serem oferecidas tanto no SESC quanto no grupo Pioneiras de Rondônia.

No grupo Pioneiras, quem decide as atividades é... [Pensando]. São duas pessoas, [Cita o nome das coordenadoras do grupo Pioneiras de Rondônia] (Yara).

No momento [Fala baixinho] é a diretora do SESC, juntamente com uma moça com nome [Cita o nome da profissional que define as atividades a serem oferecidas] (Yara).

É a diretora né? É a, é a [Menciona o nome da coordenadora de lazer do SESC] a coordenadora (Taynara).

Constata-se que, tanto no programa TSI do SESC quanto no grupo Pioneiras de Rondônia, a participação das usuárias na tomada de decisões é limitada. Esse resultado é compreensível na medida em que, conforme dizem Miro e Silva (2010), a lógica capitalista e do mercado impõe um padrão privatista, deixando os valores da democracia e cidadania com 
espaços restritos. A partir do que afirmam esses autores, pode-se dizer que uma participação ativa dos usuários caracteriza-se pelo envolvimento da comunidade diretamente beneficiada na reestruturação ou implementação de programas. A democratização da gestão das atividades poderia ampliar a diversidade de oportunidades de lazer, chegando-se ao que Marcellino denomina de participação cultural. Para Marcellino (2008), a efetivação do lazer como um instrumento de participação cultural implica no incentivo do poder público nos diferentes grupos sociais para manifestações culturais. Entretanto, é importante que haja envolvimento ativo dos usuários na tomada de decisões, indicando ser uma proposta que caminha para possível superação de visões ultrapassadas, com reflexo na formação de pessoas críticas e criativas.

$\mathrm{Na}$ realidade de lazer das idosas, parece que a participação delas se dá em nível elementar, ou seja, de escolha dentre um rol de atividades, programas e horários disponibilizados pelos coordenadores.

Ele [Coordenador] chamava a gente perguntava se a gente queria, né? Participar (Jurema).

A gente, sempre quando eles perguntam a gente fala [Sobre a definição das atividades a serem oferecidas]. Quando não, a gente escolhe por si própria mesmo. A gente escolhe. Ab! não quero isso, eu quero aquilo (Apuana).

Não. A pessoa que é responsável é que marca, né? Lá, o que tem que fazer, o horário, o dia. E eles dão oportunidade de escolha dessas atividades. (Taynara).

Ali tem pra pessoa escolher o que quer, né? (Aracy)

Mendonça, Silva, Oliveira e Dantas (2009), ao discutirem aspectos considerados importantes e inovadores no modo dominante de se fazer políticas sociais de lazer no Brasil, apontam a necessidade de mudanças na lógica centralizadora de tomada de decisões. Tal aspecto é fundamental para o sucesso não só de políticas de esporte recreativo e de lazer, mas para qualquer outra política social promovida pelo Estado Brasileiro. Segundo os autores, a participação efetiva da população, nas tomadas de decisões, é a ordem social desejável dentro de um processo democrático, e uma neces- 
sidade para o desenvolvimento social dos integrantes. Se for certo que o lazer, quando concebido e vivenciado como fenômeno sociocultural, potencializa o desenvolvimento e a transformação das pessoas, assumindo um papel fundamental no pleno exercício da cidadania (Gomes; Pinheiro; Lacerda, 2010), a fragilidade na democratização dos projetos e programas vinculados às práticas de lazer vivenciadas pelas idosas perdem um pouco do seu potencial transformador social e pessoal. Não se observa na fala das depoentes nenhum movimento contrário aos padrões estabelecidos na forma de organização dos programas de lazer dos quais fazem parte.

Seja por dificuldade na consciência orientada, seja pela fragilidade na capacidade de análise e adoção de novas condutas, as falas das depoentes são frequentemente de gratidão pelo acesso a vivências até então inexistentes nas fases de vida anteriores à idade. Entretanto, no interior dessas limitações, apresenta-se o grupo "Pioneiras de Rondônia", criado pelas próprias idosas, que pode, apoiando-se no dizer de Bruhns (1997), se fortalecer como um movimento de resistência, que pode caminhar para a construção de um processo totalmente democrático na tomada de decisões dos programas de lazer.

Apesar da afirmação de Ploner, Michels, Oliveira e Strey (2017) de que as pessoas são diferentes e seu processo de envelhecimento também acompanha essa diferença, observaram-se inúmeras afinidades na trajetória de vida das mulheres depoentes. Desse modo, diferenças e afinidades favorecem forte aproximação nos comportamentos sociais. A identificação com o trabalho e a valorização das vivências atuais de lazer são resultados de valores historicamente construídos que se iniciaram na infância e na meninice, fortalecidos na adolescência e na maturidade.

\section{Considerações finais}

Com base nos achados deste estudo sobre o lazer de idosas da Amazônia, conclui-se que existe um distanciamento entre o que a literatura aponta como lazer e seu papel social, e as práticas desse fenômeno na vida das mulheres. Constatou-se que todas as idosas participantes do estudo 
são financeiramente independentes, ainda que a maioria delas receba proventos insuficientes para garantir que vivam de modo estável; se privam de algumas atividades, sobretudo de lazer. A inserção delas no TSI do SESC tem oportunizado que aprendam a atribuir valor ao tempo-livre e a vivenciar, através de inúmeras atividades, práticas propiciadoras de melhoria na qualidade de vida com enfoque na saúde, além de oportunidades de descontração e socialização. Essa vivência é acessível, mesmo para aquelas com parcos proventos.

Inegavelmente, o grupo de convivência do SESC/RO exerceu e exerce papel importante, junto das idosas. Configura oportunidade quase que exclusiva para participação da vida social dessa população que, na sua maioria, não desfruta de práticas de lazer com a família.

O grupo "Pioneiras de Rondônia", recém-criado pelas próprias idosas, vem ampliar o leque de oportunidades de adoção de compromissos enriquecedores e ampliação do processo de desenvolvimento humano e social dessa população.

Entretanto, em ambos os grupos de convivência, constata-se a necessidade de ampliação da forma de gestão dos programas, cuja ação deve culminar com o aumento em quantidade e qualidade da oferta de atividades. $\mathrm{O}$ fato de não terem tido acesso à educação para o lazer e nem vivenciado essa prática de modo satisfatório nas fases anteriores da vida, juntamente com valores sociais e culturais arraigados, faz que elas não vislumbrem a possibilidade de atuarem nas esferas de decisão dos respectivos grupos de convivência. $\mathrm{Na}$ maior parte de suas vidas, só trabalharam e não tiveram oportunidade de exercer o direito ao lazer, daí se sentirem imensamente agradecidas pelas vivências de que dispõem atualmente. Ocorre que, quanto maior o nível de participação, maior aproximação da cidadania; e, da mesma forma, na efetivação da cidadania, ocorrem elevados níveis de participação. Por esse motivo, a ampliação para uma participação ativa, em todos os níveis de decisões das práticas de lazer, em ambos os grupos de convivência, poderia ser um elemento importante no alargamento do exercício de cidadania dessas mulheres. 
As práticas de lazer das idosas depoentes constam de atividades físicas diversas, tais como danças, hidroginástica, movimentos variados, viagens, desfiles, práticas de estimulação da memória e chás. Essas últimas têm fortes características inclusivas, pois possibilitam a participação daquelas com dificuldades de locomoção e que são excluídas das atividades de movimento. $\mathrm{O}$ incremento de mais atividades culturais (tais como cinema, teatro, leituras, jogos cognitivos, coral, entre outros) ampliaria a acessibilidade daquelas com mobilidade reduzida, eliminando barreiras que vêm impedindo o efetivo exercício dessa expressão humana de algumas idosas.

Dentre os conteúdos de lazer oferecidos por ambos os grupos, deduz-se a necessidade de implementação de práticas de lazer mais comprometidas com o desenvolvimento pessoal e social, com a cidadania.

\section{Referências}

BELO, I. Velhice e mulher: vulnerabilidades e conquistas. Revista Feminismos, v.1, n.3, set./dez. 2013. Disponível em: <http://www.feminismos.neim.ufba.br/index.php/revista/ article/viewFile/84/82>. Acesso em: 16 dez. 2015.

BOSI, E. Memória e sociedade: lembranças de velhos. São Paulo: Tao. 1979.

BRUHNS, H.T. Relações entre Educação Física e o lazer. In: BRUHNS, H.T.(Org.). Introdução aos estudos do lazer. Campinas: Edunicamp, 1997.

DUMAZEDIER, J. A revolução cultural do tempo livre. São Paulo: Estúdio Nobel. SESC, 1994.

GOMES, C.; PINHEIRO, M.; LACERDA, L. Direitos sociais: Questão de acesso e participação. In: Lazer, turismo e inclusão social: intervenção com idosos. Belo Horizonte: UFMG, 2010.

MARCELLINO, N.C. Estudos do lazer: uma introdução. 3. ed. Campinas: Autores Associados, 2002.

MARCELLINO, N.C. A teoria sociológica da decisão e a ação comunitária como estratégia de planejamento em ação. In: Como fazer projetos de lazer: Elaboração, execução e avaliação. (Org.). PINTO. L.M.S.M. Campinas: Papirus, 2007.

MARCELLINO, N.C. Políticas de lazer: Mercadores ou educadores? Os cínicos bobos da corte. In: MARCELLINO, N.C. (Org.). Políticas públicas de lazer. Campinas: Alínea, 2008 . 
MENDONÇA, L.C.P.; SILVA, E.A.P.C.; OLIVEIRA, N.S.; DANTAS, E.R. Pelo direito ao lazer: participação e mobilização social no bairro do Santa Rosa. Campina Grande: EDUEPB, 2009.

MOURA, G.A.; SOUZA, L.K. Práticas de lazer de idosos institucionalizados. Rev. Movimento, Porto Alegre, v. 19, n. 4, p. 69-93, out./dez. 2013. Disponível em: <http://www.seer. ufrgs.br/Movimento/article/viewFile/36131/27445>. Acesso em: 16 dez. 2015.

MORI, G; SILVA, L.F. Lazer na terceira idade: desenvolvimento humano e qualidade de vida. Motriz, Rio Claro, v.16, n.4, p. 950-957, out./dez. 2010. Disponível em: <http://www. scielo.br/pdf/motriz/v16n4/a15v16n4.pdf>. Acesso em: 20 dez. 2017.

NUNES, M.F.O.; HUTZ, C.S. Análise da Produção de Artigos Científicos sobre o lazer: Uma Revisão. Psicologia: Teoria e Pesquisa, v.30, n.3, jul./set., 2014, Disponível em: <http://www.scielo.br/pdf/ptp/v30n3/08.pdf >. Acesso em: 9 ago. 2018.

PLONER, K. S.; MICHELS, L. R. F.; OLIVEIRA, M. A. M.; STREY, M. N. O significado de envelhecer para homens e mulheres. Disponível em: <http://books.scielo.org/id/ hn3q6/pdf/silveira-9788599662885-14.pdf>. Acesso em: 10 out. 2017.

PONT GEIS, P. Atividade física na terceira idade: teoria e prática. 5. ed. Porto Alegre: ArTmed, 2003.

SCHNEIDER, R.H.; IRIGARAY, T.Q. O envelhecimento na atualidade: aspectos cronológicos, biológicos, psicológicos e sociais. Estudos de Psicologia, Campinas, v.25, n.4, out./ dez., 2008. Disponível em: <http://www.scielo.br/pdf/estpsi/v25n4/a13v25n4.pdf>. Acesso em: 20 out. 2017.

SESC. Serviço social do comércio. Disponível em: <http://www.sesc.com.br/portal/Assistencia/Trabalho+Social+com+Idosos/>. Acesso em: 1 nov. 2017. 


\section{Sobre os autores}

Ramon Núñez Cárdenas: Graduado em Educação Física pelo Instituto Superior Pedagógico Juan Marinello (1987), título revalidado pela Universidade Federal de Santa Maria (1987). Especialização em Ciências Aplicadas ao Esporte pela Universidade de Caxias do Sul (2004), Mestrado em Educação Física, com título revalidado pela Universidade Federal de Minas Gerais (1997), Doutorado em Biologia Experimental pela Fundação Universidade Federal de Rondônia (2013) e Pós-doutorado pela Fundação Oswaldo Cruz (2014). Atualmente é Professor da Universidade Federal de Rondônia, categoria Adjunto III, Revisor de periódico da Perspectivas online: biológicas e saúde e Membro de corpo editorial da Psychtech E Health jornal e coordenador do Centro de Desenvolvimento de Pesquisas em Políticas de Esporte e Lazer de Rondônia. Tem experiência na área de Educação. Atua principalmente nos seguintes temas: anemia e malária, desempenho físico e nutricional, atletas.

Ivete de Aquino Freire: Graduada em Educação Física pela Faculdade Estadual do Pará (1984), Mestrado em Educação Física pela Universidade Gama Filho (1993) e Doutorado em Sociedad y Culturas Contemporáneas, Universidad de Alicante/España (2000). Diploma revalidado pela UNB/Brasil. Atualmente é professora Associada-aposentada na Universidade Federal de Rondônia/UNIR. Líder do Grupo de Estudos do desenvolvimento e da cultura corporal e pesquisadora do Centro de Desenvolvimento de Pesquisas em Políticas de Esporte e Lazer de Rondônia. Área de atuação: Atenção multiprofissional em saúde; Políticas públicas de Esporte e Lazer.

Rosa de Luz Ambrósio dos Reis Miranda Sá: Possui graduação em Educação Física pela Universidade Federal de Rondônia (2005), especialização em Personal training: atividade física para idosos, pela Universidade de Araraquara (2016) e especialização em Ciência do Movimento Humano pela Universidade Federal de Rondônia (2008). 
Ednes Pereira dos Santos Souza: Possui Pós-graduação em Metodologia do Ensino Superior pela Faculdade Porto Velho-FGV (2015) e Pós Graduação em Ciência do Movimento Humano pela Universidade Federal de Rondônia - UNIR, (2009). Tem experiência nas áreas afins de Educação Física, com ênfase em Atividade Física e Saúde, Fitness Academia, Pilates Completo e Docência em Educação Física Escolar na Educação Infantil, Fundamental, Médio e Superior. É docente da Faculdade Metropolitana do Curso de Educação Física (Licenciatura e Bacharelado).

Fernanda Gahu de Oliveira: Possui ensino médio, segundo grau pelo Instituto Federal de Educação Ciência e Tecnologia de Rondônia (2014). Graduada de Educação Física na Universidade Federal de Rondônia. Atuou como voluntária no Centro de Desenvolvimento de Pesquisas em Políticas de Esporte e Lazer de Rondônia e atualmente é bolsista deste mesmo centro.

Marcelo Tiago Baltazar Correa: Graduação em Educação Física na Universidade Federal de Rondônia. Foi bolsista do Centro de Desenvolvimento de Pesquisas em Políticas de Esporte e Lazer de Rondônia.

Paola Tristão de Lima: Graduada em Educação Física na Universidade Federal de Rondônia. Atuou como voluntária no Centro de Desenvolvimento de Pesquisas de Esporte e Lazer em Rondônia.

Stefhany Soares Maia: Graduada em Educação Física. Universidade Federal de Rondônia, UNIR, Brasil. Atua como apoio técnico no Centro de Desenvolvimento de Pesquisas em Políticas de Esporte e Lazer de Rondônia.

Idê Freire Seixas: Possui graduação em Curso de Ciências Sociais - Fundação Universidade Federal de Rondônia (2009) e graduação em Direito pela Faculdade de Ciências Humanas Exatas e Letras de Rondônia (2001). Mestrado em Ciência da Educação. Atualmente é professora do Governo 
do Estado de Rondônia (SEDUC RO), Professora na Pós Graduação da Faculdade Porto. Tem experiência de docência na área de Direito, Administração e Pedagogia, atuando principalmente nos seguintes temas: Tecnologia, Ensino Superior, Projeto, Representação Comercial, Informatização, Avaliação e Docência no Ensino superior.

Iná de Aquino Freire: Possui graduação em Pedagogia pela União das Escolas Superiores de Rondônia (2010), graduação em Educação Física pela Escola Superior de Educação Física do Pará (1981), especialização em Gestão Escolar pela Universidade Federal de Rondônia (2003), especialização em Administração e Gerenciamento Escolar pela Universidade Federal de Rondônia (2002), especialização em Educação Física em Ginástica Escolar pela Universidade Estadual da Amazonas (1986) e mestrado em Ciencias de la Educación pela Universidad Técnológica Intercontinental da República del Paraguay (2014). Atualmente é Professora do Instituto Estadual de Educação Carmela Dutra. Tem experiência na área de Educação.

Andrea Nascimento Ewerton: Possui graduação em Licenciatura Plena em Educação Física pela Universidade Estadual do Pará (1990), cursou especialização na UFPA em Educação Motora e Esporte na Escola, participou de diversas disciplinas como aluna especial do curso de mestrado em educação na UNB, mestre em lazer pela UFMG, Especialista em Gestão Pública pela Fundação Perseu Abramo e UNICAMP, Cursa Doutorado em Educação Física na Universidade do Espírito Santo e Mestrado Profissional em Estado, Governo e Política Pública, pela Faculdade Latino Americana de Ciências Sociais e Fundação Perseu Abramo . Possui experiência em Educação Física na educação infantil, ensino fundamental e médio, em dança e ginástica em academia, foi bailarina e coreógrafa entre os anos de 1980 a 1995. Desde 1997, atua em Gestão Pública, entre 1997 a 2002, na gestão municipal, assumindo a coordenação do Esporte Educacional na Coordenadoria de Esporte, Arte e Lazer e, posteriormente, a coordenação do Ensino Fundamental na Coordenadoria de Educação, ambas na Secretaria Municipal de Educação da Prefeitura de Belém. 
Lilian Maria Moser: Possui graduação em História pela Universidade Federal de Rondônia (1992), mestrado em História pela Universidade Federal de Pernambuco (1995) e doutorado em Programa de Pós Graduação em Desenvimento Sustentável - Núcleo de Altos Estudos Amazônicos, da Universidade Federal do Pará (2006). Atualmente é professora titular da Universidade Federal de Rondônia.

Walace Henrique Reis Melo: Graduado em farmácia generalista na Faculdade Integrada Aparício Carvalho - FIMCA, ex-Aluno de Iniciação Científica, desenvolvendo pesquisa na área de Bioquímica, com ênfase em Caracterização de Biomoléculas, no Centro de Estudos de Biomoléculas Aplicadas à Saúde - CEBio/Fiocruz.

Leila Mirtes Magalhães Pinto: Possui graduação em Licenciatura em Educação Física pela Universidade Federal de Minas Gerais (1972), mestrado em Educação Física pela Universidade Estadual de Campinas (1992) e doutorado em Educação pela Universidade Federal de Minas Gerais (2004). Atualmente é Diretora do Departamento de Ciência e Tecnologia do Esporte (DCTEC) da Secretaria Nacional de Desenvolvimento de Esporte e de Lazer (SNDEL) do Ministério do Esporte. Tem experiência na área de Educação Física, com ênfase em Educação Física, atuando principalmente nos seguintes temas: políticas de esporte e lazer, recreação, lazer e educação física, lazer e educação, lazer e motricidade humana e conceito de lazer. 

